\title{
“Olhares e Perspectivas sobre a Educação Ambiental, a Democracia Participativa e o Empowerment de Crianças e Adolescentes em Escolas da Rede Municipal de Ensino de São Paulo"
}

\section{Mirtes Moreira Silva}

Tese apresentada ao Programa de PósGraduação em Saúde Pública para obtenção do Título de Doutor em Saúde Pública.

Área de Concentração: Serviços de Saúde Pública.

Orientadora: $\operatorname{Prof}^{\mathrm{a}} \operatorname{Dr}^{\mathrm{a}}$ Maria Cecília Focesi Pelicioni. 
É expressamente proibida a comercialização deste documento tanto na sua forma impressa como eletrônica. Sua reprodução total ou parcial é permitida, exclusivamente, para fins acadêmicos e científicos, desde que na reprodução figure a identificação do autor, título, instituição e não da tese. 


\section{DEDICATÓRIA}

A Deus, força que emerge diante das minhas fragilidades, razão e sentido que orienta minha vida.

Aos meus preciosos pais, Miguel e Clarice, donos de um amor inesgotável, exemplos com os quais aprendi a superar as adversidades e a me dedicar com zelo e paixão aos inúmeros "ofícios" que assumi: mãe, esposa, filha, amiga, dona-de-casa, educadora, pesquisadora, militante social...

Ao meu esposo, Volnei, alguém que amo e admiro e por isso elegi para compartilhar minhas lutas, sonhos e realizações e às nossas "filhinhas": Carolina e Bianca, "obras divinas" que trouxemos a este mundo e às quais nos dedicamos a aprimorar com o devido amor e cuidado, a fim de que se tornem valiosas contribuições para melhorá-lo.

Aos meus queridos irmãos, Miriam, Mirailton e Michael (em memória) e as famílias constituídas por eles (esposos e filhos), às quais também amo e protejo como se fossem minhas.

A todos os familiares do "lado" Pedroso: cunhados (as), sobrinhos (as) e de maneira especial aos meus estimados sogros Afonsina e José (em memória).

Aos meus amigos e alunos, grandes companheiros da minha "já razoavelmente longa" jornada de vida.

Aos colegas educadores, que conhecem e renovam diariamente sua opção e por isso se comportam como verdadeiros "profetas": anunciando, denunciando e, sobretudo, realizando a utopia, que para muitos, nessa sociedade, parece impossível. 


\section{AGRADECIMENTOS}

À minha querida orientadora, $\operatorname{Prof}^{a} \operatorname{Dr}^{a}$ Maria Cecília Focesi Pelicioni, uma referência de amizade, carinho, humildade e competência que me acompanhou durante todos esses anos.

Aos valorosos mestres que generosamente compartilharam comigo seus conhecimentos e experiências, ao longo dos sete anos de FSP/USP. De maneira especial, à Prof ${ }^{a}$ Dr $^{\mathrm{a}}$ Vitória Kedy Corneta e ao Prof. Dr. José Luis Negrão Mucci, meu orientador no Mestrado, pela confiança, carinho e incentivo constantes.

A dois admiráveis educadores que, na passagem por minha jornada acadêmica e profissional, me conquistaram pelo cuidado e amorosidade para com o outro no exercício do magistério: Prof ${ }^{a}$ Flávia Schilling (FE-USP) e Prof. Fernando José de Almeida (PUC-SP e SME).

A todos os professores, que quer na qualificação, ou na pré-banca contribuíram de forma valiosa para que esse trabalho pudesse ser aprimorado.

À Secretaria Municipal de Educação (Gabinete, DOT e Coordenadorias), que autorizou a realização da pesquisa.

À amiga de infância, Leila Teixeira da Silva, grande educadora e parceira em todos os momentos pessoais e profissionais importantes de minha vida.

Às professoras Vera Lúcia Pedroso Pereira, Eni de Morais Rocha e Vera Lúcia Aparecida, pelas contribuições oferecidas na fase inicial deste trabalho.

Aos participantes da pesquisa: Diretores, coordenadores pedagógicos, assistentes de direção, professores, alunos e pais, pela acolhida, interesse e compromisso.

À equipe de funcionários do Departamento de Prática da FSP/USP, de maneira especial à Lívia e ao Marcelo, sempre tão atenciosos e competentes. 
UMA HOMENAGEM ESPECIAL

Os profetas não são homens ou mulheres

Desarrumados, desengonçados, barbudos,

Cabeludos, sujos, metidos em roupas

Andrajosas e pegando cajados.

Os profetas são aqueles ou aquelas que

Se molham de tal forma nas águas da sua

Cultura e da sua história, da cultura e da

História de seu povo, dos dominados do seu

Povo, que conhecem o seu aqui e o seu agora e,

Por isso, podem prever o amanhã

Que eles mais que adivinham, realizam...

Eu diria aos educadores e educadoras,

Ai daqueles e daquelas, que pararem com a

Sua capacidade de sonhar, de inventar a sua

Coragem de denunciar e de anunciar.

Ai daqueles e daquelas que, em lugar de

Visitar de vez em quando o amanhã, o futuro,

Pelo profundo engajamento com o hoje,

Com o aqui e com o agora, se atrelem a um

Passado, de exploração e de rotina.

(Freire in: Brandão, 1983) 


\section{RESUMO}

SILVA MM. Olhares e perspectivas sobre a educação ambiental, a democracia participativa e o empowerment de crianças e adolescentes em escolas da Rede Municipal de Ensino de São Paulo. [Tese de doutorado] São Paulo (BR): Faculdade de Saúde Pública da Universidade de São Paulo; 2009.

Introdução: A sociedade atual tem sofrido com o agravamento dos problemas ambientais e da crise ecológica. Enfrentar essas questões impõe à Educação um grande desafio. A educação ambiental escolar pode proporcionar o empowerment dos educandos, por meio da reflexão, da tomada de consciência e da formação de valores compatíveis com a construção de uma sociedade sustentável. Objetivos: Verificar se a educação ambiental é praticada nas escolas investigadas, suas estratégias, os atores envolvidos e as dificuldades enfrentadas; conhecer a opinião e o envolvimento de educadores, pais e alunos com a democracia participativa e o protagonismo dos estudantes; identificar os impactos do trabalho pedagógico na saúde ambiental e na qualidade de vida de suas comunidades educativas. Métodos: Pesquisa qualitativa do tipo pesquisa-ação. Instrumentos de investigação: grupo focal com professores, entrevistas com alunos e pais e questionários com as equipes técnicas de dez escolas públicas municipais de São Paulo. Resultados: A Educação Ambiental, a democracia participativa e o empowerment dos alunos ainda é uma realidade distante na maioria das escolas. As estratégias carecem de planejamento, são pontuais e individualizadas. Os educadores necessitam de formação e condições de trabalho adequadas. A forte cultura hierárquica e a acomodação dos educadores dificultam a democracia participativa nas escolas, mas há exemplos bem sucedidos de protagonismo dos alunos e participação da comunidade. Há divergências sobre a saúde ambiental da escola, a influência governamental e o papel de cada membro da comunidade educativa sobre o sucesso ou fracasso dos projetos pedagógicos. Conclusões: Prevalecem os currículos, práticas e concepções típicas de uma educação conservadora na maioria das escolas, apesar do consenso geral sobre a necessidade de formar alunos cidadãos críticos, participativos, éticos e felizes para uma sociedade melhor e sustentável.

Descritores: educação ambiental escolar; participação democrática; empowerment; cidadania ativa; sociedade sustentáve 


\begin{abstract}
Silva MM. Olhares e perspectivas sobre a educação ambiental, a democracia participativa e o empowerment de crianças e adolescentes em escolas da Rede Municipal de Ensino de São Paulo/ The views about environmental education, participative democracy and the children and adolescent's empowerment in schools of the public system of education of São Paulo City. [thesis]. São Paulo (BR): Faculdade de Saúde Pública da Universidade de São Paulo: 2009.
\end{abstract}

Introduction: Nowadays the ecological crisis and the environmental problems around the world have been an important preoccupation. To the education it means a great challenge. So, the environmental education in school could provide the empowerment of the students by making them conscious about the values and acts necessary to get a sustainable society. Objectives: To verify if the environmental education had been practiced in the schools; the strategies adopted, the actors, and difficulties of them; to know the opinions and the involvement of teachers, students and parents with participative democracy and protagonist acts of the students; to identify the effects of the education projects in the environmental health and quality of life of the schools. Method: That's a qualitative method with three investigation instruments: focal groups (teachers), interviews (students and parents) and questionnaires (technical groups' members) of ten public schools of São Paulo City. Results: A few number of the school developed environmental education, democratic participation and empowerment of their students. Most of them explained that they developed their work by the use of punctual and disconnected actions. In general, teachers showed that they need to be better prepared to this task. Also their work conditions need to be improved. The strong power structure of the schools is a great problem to install the democratic participation of their members. There were different opinions about health environmental conditions of the schools, the educations projects and the governments or members of the schools' papers over them. Conclusions: Traditional curriculums and practices based on old conceptions of education were presented by the most of schools, although they had the aim to make conscious, ethics, participative and happy citizens for a healthy and sustainable society.

Descriptors: school's environmental education; democratic participation; empowerment; active citizenship; sustainable society. 


\section{ÍNDICE}

$\begin{array}{ll}\text { Apresentação } & 01\end{array}$

I - INTRODUÇÃO

1. Modernidade e globalização - perspectivas para o século XXI 11

2. A degradação ambiental e a crise ecológica 14

3. A questão da sustentabilidade: conceitos, imprecisões e uma saída possível 21

4. A educação: caminho para um mundo sustentável 25

4.1. Construir um saber ambiental e a participação cidadã: princípios 28 básicos para sociedades sustentáveis

4.2. A importância da EA - qual EA? $\quad 30$

5. A escola e a autonomia: o Estado, a sociedade civil e o mercado 36 orientando as propostas educacionais

6. Currículos x currículos: opção ideológica 48

6.1. A importância da construção coletiva do Projeto Político-Pedagógico 56 da escola e da definição da concepção de educação

6.2. O desafio de formar educadores emancipadores 58

6.3. De alunos protagonistas a cidadãos participativos - o espaço a ser 63 conquistado e as experiências já vivenciadas pelas escolas paulistanas: OP-Criança e as Conferências Infanto-Juvenis do Meio Ambiente

6.3.1. A comunidade educativa: do direito da criança à opção de educadores 79 e pais por essa concepção de educação

6.3.2. A contribuição dos movimentos sociais para o processo educativo 85 rumo a uma cidadania ativa

6.4. A educação ambiental em um currículo emancipatório 88

6.4.1. A construção de ambientes saudáveis nas escolas cruzando os 91 caminhos da EA escolar: do cenário mundial às experiências locais na Rede Municipal de Ensino de São Paulo

$\begin{array}{ll}\text { II - OBJETIVOS } & 107\end{array}$

$\begin{array}{ll}\text { III - METODOLOGIA } & 109\end{array}$

IV - ANÁLISE E DISCUSSÃO DOS RESULTADOS 119

1. Os grupos focais 119

2. Entrevistas com alunos 163

3. Entrevistas com os pais 177

4. Questionários com as equipes técnicas 186

$\begin{array}{ll}\text { V - CONCLUSÕES } & 201\end{array}$

VI - CONSIDERAÇÕES FINAIS 209

VII - REFERÊNCIAS

$\begin{array}{ll}\text { ANEXOS } & 232\end{array}$ 
ANEXO 1- Termos de Consentimento Livre e Esclarecido 232

ANEXO 2 - Roteiro do Grupo Focal $\quad 236$

ANEXO 3 - Questões da entrevista estruturada com pais 238

$\begin{array}{ll}\text { ANEXO } 4 \text { - Questões da entrevista estruturada com alunos } & 239\end{array}$

$\begin{array}{ll}\text { ANEXO 5 - Questionário com as equipes técnicas } & 240\end{array}$

ANEXO 6 - Carta das Responsabilidades Vamos Cuidar do Brasil 244

ANEXO 7 - Registros do OP-Criança em uma escola da Rede Municipal de São 246

Paulo (2004)

ANEXO 8 - Registro da responsabilidade escolhida pelos alunos e desenvolvida $\quad 249$

na escola B após Conferência Infanto-Juvenil em 2005

ANEXO 9 - Relatórios dos encontros realizados pela pesquisadora para

organização do Grêmio Estudantil na escola I

ANEXO 10 - Blog produzido pela escola E após início do projeto para construção

263

da Agenda 21 Escolar

ANEXO 11 - Conteúdo programático do Curso "Zona Leste Cidadã” 


\section{SOBRE O SÉCULO XXI}

(...) É preciso considerar o mundo sob outra ótica, outra lógica, outro meio de conhecimento. Necessário se faz, por exemplo, buscar a paridade essencial que existe entre todas as coisas: dissolver as extremas hierarquias de poder e de valor; subsumir o destino do Homem no destino de nosso planeta Terra.

(...) Chegaremos ao século XXI com uma mala na mão. $O$ que estará dentro da mala de cada um? Certamente o sentimento aguerrido de lutar por uma sociedade mais justa e menos perversa. Lembranças, sonhos, experiências e projetos.

(...) Abramos nossas malas. Retiremos de lá o que trava e dificulta o ideal de uma sociedade onde homens e mulheres sejam mais felizes. Coloquemos em seu lugar a coragem e a paixão, qualidades das quais trememos de lançar mão para transformar $o$ mundo, "sem perder a ternura jamais" (Che). (Almeida, In: Carvalho et al, 1998;

p.25-26). 


\section{O CAMINHO E O DESAFIO...}

Eleger nossas finalidades implica integrá-las profundamente em nossos espíritos e almas, jamais esquecê-las, jamais renunciar a elas, mesmo se perdermos a esperança de constatar sua realização.

(...) Sabemos que nossas finalidades não vão inevitavelmente triunfar, e que a marcha da história não é moral. Devemos visualizar seu insucesso possível e até mesmo provável. Justamente porque a incerteza sobre o real é fundamental, é que somos conduzidos a lutar por nossas finalidades. A ecologia da ação não nos convida à inação, mas ao desafio que reconhece seus riscos, e à estratégia que permite modificar a ação empreendida.

(Morin, 1998; p.68) 


\begin{abstract}
A DIFERENÇA...
(...) Temos de aprender a caminhar e, frente às adversidades, aprender a não caminhar sozinhos. Precisamos arrancar a seiva do chão onde estamos plantados, para que não nos atrofiemos à espera dos jardineiros. Aqui, sabemos, não há jardineiros. A possibilidade de que o arbusto se transforme em árvore depende de sua capacidade de se enraizar e de resistir à força dos ventos. E só a História, projetada no futuro, poderá dizer se o que existe é um pequeno arbusto ou um Jequitibá que poderá produzir sombra aos vindantes.
\end{abstract}

(Rodrigues, 2001; p.16) 


\section{APRESENTAÇÃO}

A profissão de professora surgiu de uma forma inesperada em minha vida. Antes disso, experimentei outras funções em campos diferentes. Em 1983, ingressei na Secretaria de Saúde do Estado, para trabalhar na área administrativa. Durante o período em que lá permaneci, estive em contato com as grandes demandas e desafios da saúde pública. Pouco tempo depois, recebi o convite para lecionar Ciências e Biologia em um colégio particular no período da noite. Estava no último ano da faculdade e até então, minha expectativa era trabalhar com pesquisa em uma das áreas da Biologia e não com educação. Insisti nessa opção e após a graduação fui fazer especialização em Ecologia. Porém, foi no exercício do magistério que encontrei as respostas que procurava para algumas questões acerca do ser humano, de como se dá a construção de seus valores, de sua cultura e da diversidade de potencialidades que podem ser despertadas. Nesse início de percurso conheci muitos autores maravilhosos, entre eles, Paulo Freire, minha primeira grande referência.

Deixei a Secretaria da Saúde e o colégio particular, após prestar concurso na Rede Pública de Ensino. Ao longo de mais de duas décadas como educadora no Estado e no Município, ministrando aulas nas disciplinas de Ciências Naturais e Biologia, tenho participado de inúmeros cursos e também desenvolvido vários projetos nas áreas de saúde e meio ambiente, entre outros.

Assim como vários colegas, também enfrentei dificuldades nesse percurso, como o autoritarismo de alguns diretores, avessos ao diálogo e ao respeito pelo trabalho da equipe escolar, o descompromisso de outros, a falta de condições estruturais e de apoio pedagógico, que ora competiam à própria escola, ora a outras esferas da educação municipal ou estadual. Sempre foi trabalhoso estabelecer parcerias dentro das escolas, seja com as equipes técnicas ou com os próprios colegas professores. Com estes últimos, compartilhei da mesma sobrecarga de trabalho, acumulando aulas nas duas Redes de Ensino. Mais tarde, para me dedicar às pesquisas acadêmicas, optei pela Rede Municipal e na medida do possível, continuei também participando de cursos e acompanhando, ainda, os fóruns de discussão e movimentos sociais na minha região. 
Durante todos esses anos observei que, se por um lado os resultados positivos de alguns projetos com os quais estive diretamente envolvida me trouxeram certo reconhecimento profissional e ajudaram a destacar a própria escola, por outro, esse esforço, quase sempre solitário, não foi suficiente para envolver o coletivo da escola, mobilizando outros professores, as equipes técnicas, os funcionários para dar prosseguimento aos mesmos. Isso evitaria, certamente, que nas mudanças de gestão ou no meu afastamento das Unidades Escolares (em função de outro trabalho ou da minha própria formação, como ocorreu no mestrado), inviabilizasse a continuidade daqueles projetos, que até então, por falta de engajamento de outros membros da escola, estavam sob a minha condução.

Resolver essa questão, que não é um caso isolado dentro da educação é, certamente, um dos grandes desafios que todos, governo, sociedade e educadores, têm pela frente.

No período de 2001 a 2004, fui convidada a prestar serviços técnicos educacionais junto à Coordenadoria de Educação de Itaquera, vinculada à Secretaria Municipal de Educação de São Paulo, na Diretoria Pedagógica (antiga oficina pedagógica). Nessa ocasião, participei do Projeto “ABC Na Educação Científica-MãoNa-Massa - La Main à La Pate" (uma parceria entre a Secretaria Municipal de Educação - SME, a Academia Brasileira de Ciências e a Academia de Ciências da França), com foco na educação científica para o Ensino Fundamental I.

Em função disso, fui designada para ministrar a formação de professores e equipes técnicas, implantar e acompanhar tal projeto nas escolas da Coordenadoria de Educação de Itaquera. Para isso, recebi formação na Secretaria Municipal de Educação (SME) e pude estagiar, mais tarde, no Centro Internacional de Estudos Pedagógicos em Sèvres, na França, para ver de perto como o projeto se desenvolveu nas escolas públicas daquele país, ultrapassando as dificuldades que surgiram e se consolidando como um instrumento metodológico de grande valor para os professores franceses e de incentivo ao protagonismo dos alunos. Também na Rede Municipal de São Paulo, o projeto foi muito bem aceito, pois os educadores recebiam a formação na própria escola, nos horários coletivos de estudo e assim, contavam com o apoio pedagógico necessário e no 
tempo hábil, para adequar o novo conhecimento às suas práticas cotidianas vinculadas a realidade de suas Unidades Escolares. Tanto nesse caso, quanto no Projeto "Ler e Escrever, Desafio de Todas as Áreas", do qual também fui formadora, defendi a inserção de conteúdos sobre democracia participativa e questões socioambientais locais e globais, que embora fossem formas imprescindíveis de leitura de mundo, eram pautas negligenciadas nos cursos de formação para professores e equipes técnicas e conseqüentemente, no cotidiano escolar.

Foi dentro desse contexto, que a Coordenadoria de Itaquera, apresentou às escolas em 2003, o Programa do MEC/MMA "Vamos cuidar do Brasil com as Escolas", que introduzia uma inovação nas Conferências Nacionais do Meio Ambiente: a participação das crianças e adolescentes das escolas, na versão infanto-juvenil. $O$ referido Programa surgia como um convite e não como uma convocação, mas mesmo assim obteve adesão maciça das escolas daquela Coordenadoria, sensibilizadas que estavam pelas iniciativas anteriores e, naquele momento, também envolvidas no Orçamento Participativo-Criança, projeto institucional que incentivava o protagonismo infanto-juvenil. Esse processo, porém, não foi conduzido da mesma forma por outras Coordenadorias, fato que ficou evidenciado nos encontros de equipes que ocorriam periodicamente na SME, na Conferência Municipal de Meio Ambiente, onde as crianças tiveram uma participação especial e posteriormente no decorrer dessa pesquisa. Apesar das diretrizes gerais traçadas pela Secretaria para todas as Coordenadorias, na prática os projetos e ações nem sempre seguem a mesma ordem de prioridade no momento de execução.

Infelizmente, as questões socioambientais e suas implicações na saúde e na qualidade de vida também não ocupam as primeiras posições na ordem de prioridades políticas, sejam elas locais ou globais, até porque esta é uma preocupação que só agora passou a mobilizar uma parcela mais expressiva da sociedade. As escolas refletem essa realidade, reforçada por parte dos seus dirigentes nas diferentes instâncias, embora destes se esperasse outra visão e outro posicionamento, dada a responsabilidade maior que lhes compete dentro da educação.

Como integrante da equipe de GAAE (Grupos de Acompanhamento da Ação Educativa), inicialmente composta por um supervisor, um integrante da oficina 
pedagógica e um assessor da Universidade e responsável pela área de saúde e meio ambiente da Coordenadoria, acompanhei várias escolas, com a responsabilidade de auxiliar no diagnóstico dos problemas e fornecer o suporte técnico-pedagógico necessário para a resolução dos mesmos. Os projetos desenvolvidos levavam em consideração as necessidades sentidas pelas escolas e eram posteriormente socializados e debatidos nos momentos de Parada Pedagógica da Rede (Pólos).

Pude acompanhar algumas vezes, as ações de outras equipes de trabalho da Coordenadoria, como o OP-Criança, o Educom.Rádio, os Grêmios Estudantis, as formações dos integrantes dos Conselhos de Escola (CRECES), todos voltados para a qualificação da participação desses sujeitos em processos decisórios nas escolas.

A partir de 2002, fui convidada a integrar o Grupo de Trabalho Ambiental, uma equipe intersecretarial que compunha o Governo Local da Subprefeitura de Itaquera, criado para auxiliar no diagnóstico dos problemas ambientais, o qual iria subsidiar as discussões do Plano Diretor Regionalizado de Itaquera. Foi dessa forma que participei das plenárias do Plano Diretor daquela região e também das do Orçamento Participativo que ocorriam paralelamente.

Em 2005, com o término daquela gestão municipal, retornei para minha escola de origem como professora e logo em seguida, por indicação da Unidade Escolar e da Coordenadoria de Educação da Penha, fui escolhida para integrar o Grupo de Referência de Ciências da Secretaria Municipal de Educação, um grupo de trabalho composto por cerca de quinze professores de diferentes regiões da Cidade, que tinha como missão colaborar com a implantação dos Programas "Ler e Escrever" e de “Orientação Curricular" na disciplina de Ciências. Desta vez, porém, não houve afastamento da sala de aula e nós professores do grupo em questão, nos reuníamos uma vez por mês na SME com a responsabilidade extra de desenvolver material de apoio para professores e em algumas Coordenadorias de Educação, também promover a formação dos mesmos através de Seminários e de um Projeto denominado 'Sala dos Professores'. A partir desse trabalho desenvolvido entre 2005 e 2008, foram produzidos documentos e vídeos sob a responsabilidade de uma assessoria contratada pela SME e que vêm sendo utilizados como subsídios pelos educadores da Rede Municipal de 
Ensino de São Paulo, com a finalidade de melhorar o desempenho das escolas nas avaliações internas e externas.

Assim, durante todos esses anos de carreira no Magistério, estive em contato direto com as escolas participantes desta pesquisa, ora como professora em três delas, ora como formadora de recursos humanos em todas (que entre 2001 e 2002, pertenciam todas ao NAE-9, dividido em Coordenadoria de Itaquera e Coordenadoria da Penha em 2003), acompanhando as dificuldades e os avanços do processo de formação e de envolvimento da equipe de educadores, alunos e comunidades nos diversos projetos desenvolvidos por diferentes gestões, sobretudo os de educação em saúde e educação ambiental.

Na mesma medida em que o tempo atuava para amadurecer a minha prática como educadora, também tornava claro o desafio de encontrar uma resposta para "velhas preocupações": Como tornar prioritárias as questões relacionadas à saúde, ao meio ambiente e à qualidade de vida nos currículos-em-ação das escolas? Como envolver toda a comunidade educativa e motivá-la a ponto de evitar que investimentos e esforços fossem desperdiçados com o abandono de programas e projetos? Como incentivar a democracia participativa no espaço escolar e a adoção de posturas pedagógicas mais progressistas e inovadoras em uma Rede Pública de Ensino ainda carente de reais avanços educacionais?

Esta foi, e continua sendo, a principal razão que me faz investir nessa carreira e também nesta nova jornada acadêmica. O caminho escolhido para a investigação das práticas pedagógicas em escolas municipais, capazes de formar cidadãos conscientes e participativos, requer um olhar mais apurado sobre os mecanismos que regem as relações entre os diferentes segmentos da comunidade escolar, sobretudo no tocante ao educando, objeto principal da educação.

Para uma educação ambiental exercida a partir da perspectiva da pedagogia crítica aqui defendida, onde a reflexão e a ação, o diálogo e a inclusão sejam exercidos de forma privilegiada e constante, é imprescindível a adoção de instrumentos democráticos para atingir o objetivo de envolver o maior número possível de atores no processo de construção de uma sociedade mais justa, mais humana e mais saudável: 
uma sociedade sustentável. Neste sentido, o empowerment (ou empoderamento) de que também trata esse trabalho se refere em primeiro lugar, ao reconhecimento por parte daqueles que dirigem ou participam da educação de outras pessoas, do direito destas serem protagonistas no processo educacional e de ocuparem esta mesma posição em outras esferas da sociedade da qual fazem parte. O referido direito exige, portanto, a criação de condições concretas para que essas pessoas possam tomar decisões e agir, consciente e criticamente, tanto no plano individual quanto no coletivo, para a conquista de melhores condições de vida e de uma sociedade de fato sustentável.

$\mathrm{Na}$ introdução deste trabalho, a linha de raciocínio construída com o auxílio do referencial teórico, pretende dar sustentação às hipóteses iniciais que motivaram a investigação e que serão a seguir explicitadas:

Os desejos e expectativas expostos no discurso predominante entre os educadores destoam, muitas vezes, de suas práticas pedagógicas em relação à formação de cidadãos autônomos e participativos e à construção de uma sociedade mais ética, solidária, democrática, saudável e sustentável.

Esse descompasso poderia estar relacionado à falta de priorização de conteúdos mais significativos e de metodologias mais inovadoras e possivelmente mais eficientes e esse processo de escolha dos educadores seria influenciado por alguns fatores, entre eles:

- A ausência ou deficiência de formação nos seus campos de atuação;

- A falta de apoio pedagógico dentro da própria escola, organizando o trabalho, convocando parcerias, fornecendo subsídios teóricos e recursos financeiros elou de outros órgãos da educação para desenvolverem novos projetos;

- A descrença na eficácia das novas propostas pedagógicas ou nos gestores políticos de onde elas provêm.

Diante dessas hipóteses, cabem questões que explicam a escolha dos objetivos desse trabalho:

- Que tipo de educação ambiental tem sido praticada nas escolas da Rede Municipal de Ensino de São Paulo? 
- Quais os atores envolvidos nesse processo e as estratégias que têm sido utilizadas por eles?

- Quais as dificuldades encontradas por esses atores na construção prática da educação ambiental?

- Como os educadores, pais e alunos vêem a democracia participativa e o protagonismo dos estudantes dentro e fora da escola?

- Qual o grau de envolvimento de todos esses atores com a democracia participativa?

- Quais os impactos dos projetos e ações das escolas na saúde ambiental de suas comunidades?

Assim, a lógica definida para elucidar essas questões parte, inicialmente, de uma rápida abordagem sobre a hegemonia do racionalismo científico da modernidade e o papel da globalização na gênese dos principais dilemas vividos no momento histórico atual, como a crise ecológica. Esta tem sido vista como o resultado da escolha equivocada 'de um modo de ser e de viver' que precisa ser reformulado, delineando uma importante tarefa para a educação.

A discussão subseqüente propõe a exploração do momento de busca de um novo tipo de desenvolvimento, baseado em novas relações entre os seres humanos e destes com a natureza, caracterizando um processo de transição paradigmática e imprimindo à educação um sentido de esperança na superação desse quadro de crises instaladas no seio da humanidade.

A preocupação com a construção de um saber ambiental ancorando a participação cidadã nos processos decisórios que regem a vida das sociedades poderá definir o tipo de desenvolvimento capaz de dividir equitativamente os ganhos produzidos pela utilização mais consciente, e, conseqüentemente, menos danosa dos recursos naturais disponíveis. 
E, a partir de um recorte da educação geral, serão apresentadas as reflexões de diferentes autores sobre a importância da educação ambiental (EA). A multiplicidade de concepções e de práticas torna necessária uma nova exploração: qual EA para a realização de qual utopia?

A continuidade dessa discussão permitirá a aproximação do universo escolar na tentativa de desvelar as ideologias que permeiam as práticas pedagógicas em EA e os currículos-em-ação. Da mesma forma, serão analisadas as relações de poder constituídas dentro das comunidades educativas e o caráter educativo de outras formas de poder exercidas fora dos limites da escola, mas que podem influenciar no caminho percorrido por educadores e educandos dentro do processo educacional, como por exemplo, os movimentos sociais e outras esferas de participação pública.

Para facilitar a compreensão das questões investigadas por meio dos instrumentos de pesquisa adotados, referentes à democracia participativa nas escolas e ao empowerment das crianças e adolescentes, serão apresentados os aspectos mais importantes de algumas experiências com as quais as escolas paulistanas já entraram em contato, retrocedendo até o ano 2000, início do século XXI até o ano de 2008. Esse intervalo de tempo, embora pareça relativamente curto, foi suficiente para que a educação em São Paulo tivesse contato com três gestões políticas diferentes e, portanto, estivesse sujeita a ideologias e ações governamentais, em alguns aspectos, inclusive, divergentes no campo educacional.

Finalmente, a educação ambiental escolar tem se deparado com uma necessidade urgente no interior das U.E.s: a construção de um ambiente saudável para toda a comunidade educativa. Essa busca imprime ainda mais sentido e força para a EA e cria uma nova possibilidade para as U.E.s: tornarem-se "escolas saudáveis" e desta forma, “promotoras de saúde”. De forma sintética, procurará se mostrar o caminho percorrido por esse tipo de escola no mundo, no Brasil e na Cidade e suas perspectivas futuras. 


\section{I - INTRODUÇÃO}

\section{1 - MODERNIDADE E GLOBALIZAÇÃO - PERSPECTIVAS PARA O SÉCULO XXI}

O século XX foi marcado por um acelerado processo de desenvolvimento científico, tecnológico e industrial, acompanhado por uma revolução nos sistemas de comunicação e processamento de informações. A era da informática permitiu ao mundo acessar em tempo real informações de qualquer parte do Planeta. Apesar disso, antes mesmo que esse século terminasse, ruíram-se as falsas promessas de progresso com qualidade de vida para todos, que seriam frutos dos avanços da ciência e da tecnologia.

Assim, perante os olhos de uma civilização perplexa, surgia o avesso escondido pelos paradigmas que sustentavam a modernidade, gerando os conflitos, as preocupações e incertezas que se configuraram como "as grandes marcas" dessa fase da história da humanidade. Para GUIVANT (1998), esse progresso pode significar a potencial autodestruição da sociedade industrial. E é esta sociedade que produz novos riscos globais, que não se limitam às fronteiras dos países e nem às divisões de classes.

A globalização poderia ter unificado o Planeta, absorvendo as múltiplas identidades e criando uma nova e mais abrangente, onde todos os povos se sentissem verdadeiramente incluídos. Como pensa MORIN (2002), ela ocupou-se, entretanto, da internacionalização da produção, dos recursos financeiros, da cultura, da informação, optando por não romper as fronteiras geográficas, econômicas e sociais. O Norte e o Sul, representando, respectivamente, a riqueza e a pobreza, foram separados por um abismo que, tende a se tornar cada dia mais profundo. Para LEFF (2001, p.9) "a degradação ambiental, o risco de colapso ecológico e o avanço da desigualdade e da pobreza são sinais eloqüentes da crise do mundo globalizado". 
MORIN (2002) apresenta as contradições da mundialização, ressaltando que ao mesmo tempo em que ela pode ser unificadora, pode também ser conflituosa, na medida em que não divide eqüitativamente ganhos e prejuízos. Para ele, pobres e ricos trazem em si o melhor e o pior do Planeta inteiro, respectivamente. Como conseqüência dessa tentativa de homogeneização civilizacional, o autor lembra que não apenas se agravaram, mas criaram-se novos conflitos entre as nações: “(...) entre laicização e religião, modernidade e tradição, democracia e ditadura, ricos e pobres, Oriente e Ocidente, Norte e Sul e a eles mesclam-se interesses estratégicos e econômicos antagônicos das grandes potências e das multinacionais voltadas para o lucro" (p.70).

GADOTTI (2000), que também identifica antagonismos na globalização, observa que a globalização econômica, capitalista é confrontada pela globalização da cidadania, fruto da organização civil. Mas é a partir desse enfrentamento, que acredita ele, surgirá a cidadania planetária, onde não existirão estrangeiros, apenas "terráqueos". No Manifesto da Planetarização, ROMÃO et al (2006), chamam a atenção para a ambigüidade presente no termo "globalização". Para eles, o seu significado “(...) é um eufemismo entrincheirado atrás da acumulação capitalista, que deseja construir um mundo com um único centro de decisão" (p.211), impondo, também, um padrão mono cultural e alimentando as desigualdades sociais. Os referidos autores consideram que é preciso resistir a essa pressão dos grupos hegemônicos e suas consequiências e defendem a adoção do termo "planetarização" em substituição ao vocábulo "globalização", afirmando o seu compromisso com a construção da já mencionada "cidadania planetária".

No pensamento de MORIN (2002, p.70), o grande legado do século XX, foi a união de duas barbáries: "a primeira vem das profundezas dos tempos e traz guerras, massacre, deportação, fanatismo. A segunda, gélida, anônima, vem do âmago da racionalização, que só conhece o cálculo e ignora o indivíduo, seu corpo, seus sentimentos, sua alma, e que multiplica o poderio de morte da servidão tecnoindustriais". Acrescenta, ainda, que além do poderio de morte demonstrado nos diversos conflitos que marcaram esse século, novas formas foram inventadas, como as armas nucleares e a morte ecológica, ou ainda, os vírus mutantes e bactérias fabricadas em laboratório. Já para GADOTTI (2000), mais do que a armas nucleares ou qualquer outro risco, o verdadeiro perigo estaria no descontrole da produção industrial. 
$\mathrm{Na}$ atualidade, uma preocupação que toma corpo em todo o mundo, é a produção excessiva de "gases-estufa" não apenas pela prevalência de matrizes energéticas poluentes, mas também por outras práticas prejudiciais ao meio ambiente, entre elas, as queimadas, os desmatamentos e o consumismo desmedido, cujos efeitos já estão sendo sentidos em diferentes partes do Planeta, colocando a humanidade em alerta para a perspectiva de um futuro nada promissor em termos de segurança ambiental e recursos para a sobrevivência de gerações que aqui se encontram e daquelas que ainda poderão chegar.

Os autores a seguir relatam sobre um tipo de sociedade que nasceu sob a égide do 'desenvolvimento a qualquer custo', chamando a atenção para os perigos que corremos (nós que somos neste cenário, criadores e criaturas) e também para os esforços que a situação nos exigirá no sentido de não sucumbirmos diante dos nossos próprios erros. Sem dúvida, um dos principais desafios que esta sociedade tem pela frente é vencer o racionalismo econômico e o individualismo, que se contrapõem à ética de valorização da vida, à solidariedade, à cooperação entre pessoas, nos diferentes grupos sociais, entre nações e gerações, já que os riscos se globalizaram e todos os estratos sociais serão de alguma forma atingidos. Viver numa sociedade de riscos ambientais e tecnológicos que só tendem a se ampliar pode, por outro lado, fazer emergir ou fortalecer uma capacidade humana que leva não só à identificação como à superação de problemas: a reflexividade.

É o que acredita BECK (1997), para quem, a modernidade e a globalização são as responsáveis diretas pelos riscos previsíveis e os que ainda estão por vir e dos quais a humanidade não poderá estar isenta. Por isso mesmo, exige além da reflexividade, uma reinvenção e um repensar da civilização industrial, como sugere o autor. Nas suas palavras, "uma (auto) destruição criativa".

Como bem avalia JACOBI (2005, p.12), esse novo século surge em meio a "uma crise do ser no mundo, que se manifesta em toda sua plenitude: nos espaços internos do sujeito, nas condutas sociais autodestrutivas; e nos espaços externos, na degradação da natureza e da qualidade de vida das pessoas". 
Desta forma, se por um lado, o século XXI, desponta dentro desse cenário 'pósmoderno' de conflitos, contradições, desafios e incertezas, por outro, emerge trazendo algo de novo: um consenso crescente de que estamos diante de um momento decisivo e que adiar o enfrentamento dessa crise, significa colocar em risco qualquer chance de sobrevivência digna para as atuais e futuras gerações.

Uma saída proposta por GADOTTI (2000, p.31), denominada como "a luz no fim do túnel", seria a ecologização da economia, da pedagogia, da educação, da cultura, da ciência, já que, daqui para frente a humanidade terá com permanente a preocupação com a auto-destruição. 


\section{2 - A DEGRADAÇÃO AMBIENTAL E A CRISE ECOLÓGICA}

SANTOS (2005), por exemplo, analisando o atual espaço-tempo mundial, observa que o tripé - aumento da população, globalização da economia e degradação ambiental é o principal dilema a ser enfrentado pela humanidade, a verdadeira crise ecológica. Com o modelo econômico capitalista vigente, as desigualdades sociais entre o centro e a periferia do sistema mundial só poderão aumentar. Na avaliação do autor, a solidariedade dos países mais ricos para com os países mais pobres ainda seria insuficiente como medida para a superação desse quadro. Seria preciso um pacto de solidariedade entre as gerações presentes e futuras, que, pressuporia uma disponibilidade e uma disponibilização de recursos econômicos, sociais, políticos e culturais, um cenário mundial improvável na atualidade.

No que se refere à degradação ambiental, SANTOS (2005) afirma que suas principais causas foram a transnacionalização do empobrecimento, da fome e da má nutrição, embora ela já seja em si, apenas um dos aspectos de um fenômeno ainda maior - "a crise ecológica". O relatório Nosso Futuro Comum apresentado pela Comissão Mundial sobre o Meio Ambiente e o Desenvolvimento em 1987 (UNESCO, 1999; p.45) também se referindo às crises mundiais, prefere não individualizá-las, de maneira que se poderia compreender que estas são apenas sintomas de uma única crise:

(...) até muito pouco tempo, o Planeta era um vasto mundo no qual a atividade humana e seus efeitos podiam ser agrupados em nações, em setores com amplos campos de interesse (ambiental, econômico, social). Atualmente, essas categorias começaram a dissolver-se. Isso se aplica, em especial, às diversas 'crises' mundiais que despertaram a preocupação pública. Não se trata de crises isoladas: crise ambiental, crise do desenvolvimento, crise energética. Trata-se da mesma crise.

A degradação ambiental seria segundo a análise de SANTOS (2005), talvez o problema mais transnacional de todos, cujas perspectivas de solução não são muito promissoras. $\mathrm{O}$ autor argumenta que essa dificuldade decorreria do fato de que os países do Norte têm forte resistência em substituir o modelo de desenvolvimento, centrado na produção e no consumo desmedido dos recursos naturais e responsável pela maior parte da poluição mundial. Não teriam, ainda, nenhum interesse em investir na substituição de 
tecnologias obsoletas e altamente poluentes utilizadas pelo Sul, neste último caso, principalmente por falta de opção. Paradoxalmente esta poderia ser uma poderosa arma para pressionar o Norte a negociar condições menos díspares de sobrevivência para o Sul. Por outro lado, é possível reafirmar que com a globalização dos impactos ambientais provocados pela degradação ambiental crescente, ninguém saia vitorioso, de tal forma que a solidariedade global seria a única saída possível, mesmo que pareça, no cenário posto, uma possibilidade remota.

A superação da crise ecológica, não oferece muitos caminhos, pelo menos se projetarmos para o futuro a persistência dos elementos políticos, sociais e econômicos mundiais que determinam a nossa realidade atual. Reconhecendo a dificuldade dessa tarefa, só resta creditar ao desejo e ao esforço contínuo dessa sociedade a possibilidade do surgimento de uma nova concepção científica e em um novo projeto de civilização, como defendem PHILIPPI JR \& PELICIONI (2000), no qual a ética da promoção da vida seja o centro de um processo histórico que considere a universalidade do ser humano. Para tanto, a exclusão e a pobreza maciça no mundo, devem ser problematizadas e invertidas por meio de ações concretas, bem como as relações de consumo. Em uma última análise, os autores sugerem que esse aspecto vai exigir mudanças decisivas nas relações do homem com a natureza e contínuas reflexões sobre as ações nesse sentido. As relações do homem com o próprio homem, no entanto, deverão encabeçar esse processo de mudança, pois são determinantes na construção desse novo olhar sobre as outras formas de vida e o valor único que cada elemento tem dentro dessa complexa teia que envolve todo o planeta.

Diante disso, para não cairmos no risco de imobilismo inimaginável, ou como diria SANTOS (2005; p.324), em uma "perda da inquietação e busca de uma vida melhor", é preciso reinventar a utopia que morreu junto com o futuro, já que não há futuro no futuro prometido pela modernidade.

Ainda que o futuro pareça cada vez mais problemático, não se pode esperar que uma volta ao passado consiga resolver esses problemas, já que as revoluções industriais e pós-industriais deixaram como legado profundas transformações na sociedade e nos seus valores e se insistirmos nessa atitude, como alerta a UNESCO (1999), poderemos cair num estado de frustração e eventualmente até mesmo de violência e niilismo. 
Assim, é necessária a busca de um novo futuro, projetado por um novo paradigma. E, se por um por um lado, a utopia representa aquilo que não pode ser realizado, por outro, o que há de mais importante nela é a possibilidade da emergência de uma nova psicologia e de uma nova epistemologia, que no primeiro caso permitirá à utopia a recusa do conformismo e no segundo caso, a criação de alternativas (SANTOS, 2005).

Nesse sentido, SANTOS NETO (2004) chama a atenção para os discursos e, sobretudo para as outras formas de resistência daqueles que proclamam o "fim da História", do sonho, da utopia, da esperança, porque na verdade, o que está por trás disso é a defesa do sistema capitalista como única saída para a sociedade atual e futura. Esta é para FREIRE (1996) a "ideologia fatalista e imobilizadora”.

No entanto, a existência da utopia é uma constante na história do Homem. REIGOTA (2001), por exemplo, acredita que ela não deva ser identificada como algo irrealizável ou ingênuo e cita o pensamento ambientalista como a prova mais contundente de sua presença na atualidade. MORIN (2002, p.75), por sua vez, aposta na capacidade de nossas sociedades de se aperfeiçoarem e de se transformarem. Não acredita que tenhamos chegado ao fim da História. “(...) podemos esperar progresso nas relações entre humanos, indivíduos, grupos, etnias, nações”. Segundo o autor, o renascimento da esperança passa pela possibilidade antropológica, sociológica, cultural e espiritual de progresso, porém "sem certeza científica, nem promessa histórica". Ela dependerá em grande parte da conscientização, da vontade, da coragem e da oportunidade. O surgimento de uma identidade comum, de "um sentimento de pertencimento mútuo que nos una à nossa Terra", pátria primeira e última de todos é o que deverá mover a humanidade daqui por diante. Norte e Sul, Oriente e Ocidente, devem se complementar de forma dialógica.

Nesse momento em que afloram tantas discussões acerca das crises e das possibilidades de superação das mesmas, parece propício recorrer à etimologia da palavra "crise" para compreender em que medida ela pode significar o caminho para algo irreversível ou a possibilidade da busca pela utopia, sugerida pelos autores supracitados. É igualmente interessante compreender de que forma as crises são percebidas pela sociedade e grau de afetamento que elas podem causar nas diferentes gerações que compartilham o mesmo espaço-tempo. 
Essas reflexões podem iluminar uma análise sobre o que a sociedade atual considera como "crise ambiental" ou "crise ecológica" e quais seriam os riscos ou perigos a serem enfrentados nesse momento de incertezas. Que decisões poderiam ser ou não tomadas, conscientes da imensa transitoriedade das coisas na atualidade e da dificuldade de aglutinar forças em torno delas, em um mundo cada vez mais individualizado, onde cada um joga um jogo, com regras próprias e muitas vezes escusas e onde, até mesmo o mundo é um dos jogadores, como afirma BAUMAN (2000).

BOFF (1983) retoma a origem filológica da palavra para explicar que sua raiz em sânscrito Kri significa limpar, desembaraçar e purificar. BAUMAN (2000), por sua vez, revela que o sentido da palavra "crise" foi desvirtuado ao longo do tempo, tendo em vista que esta palavra foi criada originalmente para expressar "o momento de tomar decisões". Assim, ela estava muito mais afinada com o termo "criterion", ou seja, a forma pela qual procuramos decidir acertadamente, do que com a associação com as palavras "desastre" ou "catástrofe", designações atuais. Para o referido autor, mesmo esse sentido atual também já está caindo em desuso, haja vista que ao utilizar esse termo, freqüentemente o relacionamos com um "momento de mudança decisiva".

BOFF (1983) considera que a crise é o que permite que a vida (econômica, social, pessoal) se renove, pois apesar de rupturas, traz também novas possibilidades, cujos frutos (bons ou maus) dependerão da maneira como ela será enfrentada. Sobre isso, RIOS (2001) sugere que, entre as duas perspectivas - a de perigo e a de oportunidade, devemos optar pela segunda, pois só ela nos permitirá refletir de forma crítica e assim, reorientar as nossas práticas.

A percepção da crise, na visão de BAUMAN (2000), seria precedida pela consciência da norma, ou seja, do que se considerava como normal antes dela. Para o autor, é essa reflexão, sobre o estado das coisas e suas mudanças, inerente a todo ser humano, que o fará buscar no passado os mecanismos que outrora lhe conferiam a estabilidade ou "normalidade" dentro de uma determinada situação e que agora, ou já deixaram de existir e, portanto, precisam ser resgatados, ou perderam sua eficácia, requerendo a busca de novos instrumentos. 
BAUMAN (2000, p.146) se apóia na visão de Ortega Y Gasset e acredita que diferentes gerações que convivem numa determinada época, adquiriram conhecimentos que foram construídos pelas gerações anteriores e nas interações que ocorrem entre elas no mesmo espaço-tempo. Elas prescindem da coordenação de suas ações e da comunicação entre si. Isso gerará um estado permanentemente crítico da sociedade, onde as gerações mais velhas que acumularam mais hábitos e também mais expectativas tenderão a identificar mais rapidamente um estado de crise nas situações vividas na atualidade. No entanto, para o autor, "a crise, na medida em que a noção se refere à invalidação dos jeitos e maneiras costumeiros e a resultante incerteza sobre como prosseguir, é o estado normal da sociedade humana". Para se auto constituir, se auto reproduzir ou renovar-se é preciso estar em crise. O desequilíbrio, situação recorrente na evolução das sociedades humanas, é visto pelos cientistas sociais como o princípio de toda teorização sensata.

Entretanto, ao que tudo indica, há uma preocupação da sociedade atual desproporcionalmente maior em relação às sociedades do passado, apesar de tantas crises enfrentadas também por estas ao longo do tempo. Segundo BAUMAN (2000), embora o mundo nunca tenha sido estático em termos de mudanças, elas não se davam de forma tão veloz e tão profunda como têm ocorrido na atualidade, mergulhando a humanidade, como já foi discutido anteriormente, num estado preocupante de incertezas e desorientação, que a remetem frequentemente às questões: "E agora, o que fazer?" ou “Ainda há tempo para se fazer alguma coisa?". É interessante a abordagem de BOFF (1983) sobre as diferentes posturas que podem ser assumidas diante dos momentos de crise. Assim como BAUMAN (2000), o autor supracitado se baseia nas idéias de Ortega Y Gasset, para diferenciar os grupos de indivíduos presentes na sociedade de acordo com suas atitudes. Desta forma eles poderiam ser reconhecidos como:

- Apocalípticos: aqueles que julgam que a crise é o fim do mundo, o colapso universal e se definem automaticamente contra qualquer coisa que represente um sinal de mudança, sobretudo se estes constituem a classe dominante e se tais mudanças abalarem o poder e os privilégios por eles já conquistados;

- Arcaizantes: aqueles que têm um compromisso permanente com o passado, no qual acreditam, encontrarão todas as soluções. 
- Escapistas: aqueles que criam um mundo paralelo livre da crise, no qual só há espaço para sua classe. Têm suas próprias soluções tecnocráticas e não aceitam outras opiniões.

- Res-ponsáveis: aqueles que buscam respostas (do latim: responsum) compatíveis com os problemas que se apresentam e embora considerem as experiências do passado, não se fecham para novas possibilidades do futuro, ainda que para isso tenham que tomar decisões difíceis, procurando fazê-lo sempre de maneira lúcida, refletida.

Diversos autores falam da utopia como sinônimo de esperança, entre eles, FREIRE (1980), RIOS (2001) e SANTOS NETO (2004). Eles nos lembram que se a utopia é esperança, a esperança é movimento, por isso há sempre tempo de pensar e organizar projetos utópicos, para serem realizados, sem renunciar ao direito de buscar e construir um modelo alternativo de sociedade. Esses são remédios eficazes para enfrentar as crises, para as quais não devemos jamais cruzar os braços, mas utilizar os recursos disponíveis ou lançar mão de novos a serem construídos ao longo do caminho para realizar a nossa história, o real. 


\section{3-A QUESTÃO DA SUSTENTABILIDADE: CONCEITOS, IMPRECISÕES E UMA SAÍDA POSSÍVEL}

São muitos os trabalhos nos quais é possível encontrar uma retrospectiva dos debates sobre meio ambiente e desenvolvimento sustentável, desde que o conceito de desenvolvimento sustentável foi cunhado em 1987 pela Comissão Mundial sobre o Meio Ambiente e Desenvolvimento e posteriormente registrado no Relatório "Nosso Futuro Comum" ou "Relatório Brundtland", como ficou conhecido. Neste documento, defendia-se a necessidade de se harmonizar o crescimento econômico e social no nível global com o equilíbrio natural, buscando novos mecanismos de produção mais limpos, racionalizando o consumo e priorizando ao máximo a erradicação da pobreza no mundo.

Para DIEGUES (1992) e LEIS (1999) a diversidade de interpretações do referido conceito está relacionada com os aspectos éticos que foram incorporados ao Relatório mencionado e que embora tenham causado à época, um certo impacto nos meios econômico e político, não tiveram força suficiente a ponto de gerar, concretamente, grandes transformações nesses campos. Além da própria limitação que um documento como este poderia ter, as variáveis envolvidas e as divergências em torno da importância de cada uma, os conflitos do ponto de vista teórico e político, das estratégias de implementação, bem como a função de cada setor - Estado, sociedade civil e mercado, não permitiam um consenso sobre o caminho para o desenvolvimento sustentável. Segundo PELICIONI (1998), o conceito de desenvolvimento sustentável vem sendo discutido e aplicado a partir de diferentes enfoques, servindo inclusive, para cimentar desigualdades sociais e econômicas vigentes no mundo. Apesar disso, VIOLA \& LEIS (1992), acreditam que é possível conciliar o desenvolvimento com a proteção do meio ambiente.

Na visão de LEFF (2001, p.9), a sustentabilidade é "o significado de uma falha fundamental na história da humanidade; crise de civilização que alcança seu momento culminante na modernidade, mas cujas origens remetem à concepção do mundo que serve de base à civilização ocidental" e é também o que afirmam MORIN \& KERN (1993), para os quais o desenvolvimento está diretamente ligado ao problema cultural/civilizacional e ecológico e o modelo que até então se conhecia, mergulhou em uma crise mundial. 
Entretanto, a forma como a comunidade científica, as instituições econômicas que representam mercado e a população absorvem e reagem a esse conceito é o que vai determinar se um novo processo civilizatório mais ecológico e menos racional estará a caminho ou se o paradigma econômico que regia a modernidade ressurgirá maquiado de 'neoliberalismo ambiental', como é chamado por LEFF (2001) e mais uma vez, ditará as regras. Também o referido autor, por diversas vezes em sua obra, chama a atenção para o discurso falacioso da 'sustentabilidade' proferido pelo capitalismo que procura iludir a sociedade com a retórica do equilíbrio ecológico com justiça social por meio do crescimento econômico na lógica do livre mercado. Desconsidera desta forma, a complexidade dos processos naturais e exclui as identidades culturais, apropriando-se da natureza como meio de produção e fonte de riqueza.

Nas visões convergentes da UNESCO (1999) e de JACOBI (2005), não obstante as críticas e as diferentes interpretações, talvez seja mais fácil compreender a sustentabilidade como sendo uma 'nova forma de visão', do que um conceito ou uma relação clara e bem definida. Para a UNESCO (1999), por exemplo, ela carrega, ao mesmo tempo, um preceito ético e um conceito científico, que se reporta tanto às noções de eqüidade quanto às teorias do aquecimento do Planeta. Embora, para a maioria o desenvolvimento sustentável esteja mais relacionado com as ciências naturais e econômicas, na verdade ele está muito mais ligado à cultura das pessoas, aos seus valores e à forma como se relacionam com os outros.

De qualquer forma, a necessidade de se construir um futuro sustentável é sentida e intuída pela maioria da população. Pouco importa se essa mesma população tem em mente o conceito preciso do que seja 'desenvolvimento sustentável' ou 'sustentabilidade', pois também de acordo com vários autores, entre eles, PELICIONI (1998), REIGOTA (2001) e JACOBI (2005), há inúmeras representações sociais sobre esses termos, seja no meio político, econômico da população e o tema ainda é alvo de discussão dentro da própria comunidade científica. $\mathrm{O}$ que realmente leva à percepção clara do risco e da necessidade de agir é a presença concreta dos problemas ambientais no dia-a-dia das pessoas, como as diferentes formas de poluição e seus efeitos, os congestionamentos nos espaços habitacionais, as paisagens alteradas, o aumento de doenças respiratórias, das notícias sobre a fome e miséria, a falta de água potável e as 
doenças que esse fator gera, dos gases de efeito estufa e do aquecimento global e suas consequiências: a desertificação, o aumento do nível dos oceanos, as inundações, tornados, furacões, secas e outras catástrofes naturais, além do desaparecimento de espécies entre outras coisas.

Existem, ainda, outras questões que aumentam o sentimento de desespero e angústia nas atuais sociedades, segundo os autores em referência, como a violência, guerras sem explicação, migrações em massa, ondas de corrupção generalizadas nos meios políticos, a escassez de recursos materiais, a inflação, o desemprego crescente e a diminuição da expectativa de vida de milhões de pessoas nas regiões mais pobres do Planeta. A UNESCO (1999), as designa como 'resultados dolorosos' produtos das condições de mudança, experimentados por milhões de pessoas que já nem questionam mais sobre as suas causas, mergulhadas que estão em suas lutas diárias para tentar escapar dos seus efeitos.

Há, segundo ela, outros fatores importantes e inter-relacionados que contribuem para essa situação e que podem ser designados como 'sintomas' e não como 'causas', por serem “(...) resultados do modo de pensar, de valores e práticas utilizadas nos âmbitos social, econômico e político, que colocaram o mundo em um processo de deterioração insustentável" (p.23). São eles:

- O rápido crescimento da população mundial e a mudança em sua distribuição;

- A persistência da pobreza generalizada;

- As crescentes pressões sobre o meio ambiente devido à expansão da indústria em todo o mundo e o uso de modalidades de cultivos novos e mais intensivos;

- A negação contínua da democracia, as violações dos direitos humanos e o aumento de conflitos e de violência étnica $e$ religiosa, assim como a desigualdade entre homens $e$ mulheres;

- O próprio conceito de desenvolvimento, o que significa e como é medido.

É nesse último item que segundo a referida análise, repousa grande parte do problema: quando se considera que se deva existir um equilíbrio automático entre altos níveis de produção e consumo com o desenvolvimento, utilizando-se como principal ferramenta de medição o Produto Interno Bruto (PIB). Essa estratégia mostra-se cada vez mais preocupante quando nos deparamos com a possibilidade de países emergentes como a China, a Índia, a Rússia ou o Brasil, por exemplo, perseguirem os mesmos 
padrões de consumo das atuais potências mundiais. Isso significaria o esgotamento dos recursos naturais num curto espaço de tempo, além da emissão triplicada do volume de poluentes e de outros efeitos negativos da produção, mesmo que houvesse um investimento semelhante ao que é feito pelos países mais industrializados, para minimizar a poluição. Essa atitude, entretanto, nem é esperada já que tais países não conseguem sequer satisfazer as necessidades sociais mais urgentes, por que haveriam de se preocupar com o meio ambiente? Por esta razão, para a UNESCO (1999), seria importante estabelecer meios e medidas para auxiliar esses países na resolução de problemas básicos de suas populações, sem, contudo ferir de forma irreversível o meio ambiente.

A adoção de outros instrumentos de medida do desenvolvimento como o Índice de Desenvolvimento Humano (IDH) do Programa das Nações Unidas para o Desenvolvimento (PNUD), poderia significar um enfoque mais voltado para os fins para os quais o desenvolvimento deveria servir, do que para os meios (aumento de produção). 


\title{
4 - A EDUCAÇÃO: CAMINHO PARA UM MUNDO SUSTENTÁVEL
}

\author{
Cada sociedade, considerada em momento determinado de \\ seu desenvolvimento, possui um sistema de educação que se \\ impõe aos indivíduos de modo geralmente irresistivel... Há, \\ pois, a cada momento, um tipo regulador de educação do \\ qual não nos podemos separar sem vivas resistências que \\ restringem as velocidades dos dissidentes (Durkheim, \\ citado em RODRIGUES, 2001; p.78).
}

Em sua obra sobre os saberes necessários para a educação do futuro, MORIN (2002), afirma que a educação deveria mostrar e ilustrar aos seres humanos as diferentes dimensões do destino que os espera: como espécie humana, como indivíduo, ou ser social, histórico, pois todos se encontram entrelaçados e inseparáveis. Portanto, para ele, uma das vocações essenciais da educação do futuro será o exame e o estudo da complexidade humana. Desta forma, todos poderiam conhecer e compreender que somos todos humanos e que é justamente a diversidade de indivíduos, povos e culturas que constitui a riqueza da nossa cidadania terrestre.

Parece lógico que não se pode esperar que a educação detenha sozinha, a solução para os diversos problemas da humanidade, mas é fato que ela representa um elemento essencial na busca por novas relações humanas e no incentivo a atitudes próativas em relação ao meio ambiente. Nesse sentido, há um consenso geral sobre a importância da educação, como meio mais eficaz não somente para enfrentar os desafios do futuro, como também para moldar esse novo mundo que se espera criar.

Há diversas formas pelas quais a educação pode contribuir com a sociedade, mas sua principal meta é formar cidadãos bem informados, éticos em relação à defesa e promoção da vida, responsáveis, participativos e abertos aos novos e contínuos aprendizados. Quando a educação oferece aos educandos uma visão crítica do mundo, tornando visíveis as injustiças e deficiências, estes se tornam mais conscientes e sensíveis, capazes de compreender e desenvolver novos conceitos e meios para a resolução dos problemas que a realidade lhes apresenta (UNESCO, 1999).

Destacando o papel da educação básica ou fundamental, a mesma afirma que o acesso a ela é condição essencial ao desenvolvimento sustentável, pois esta representa 
um dos meios mais eficientes para que as parcelas excluídas da sociedade concorram a uma vida mais digna e igualitária. Uma educação fundamental de qualidade é aquela que proporciona ao indivíduo o domínio necessário da alfabetização, da aritmética básica, a aquisição de atitudes e comportamentos que proporcionem a ele a conquista de uma melhor qualidade de vida. É a essa educação básica que se refere a Conferência sobre Educação para Todos (UNESCO, 1999; p.48), que explicita os seus principais objetivos: "aprender a saber, a fazer e a ser".

Além de ser um valioso canal para a divulgação de conhecimentos, a educação pode ainda:

(...) desenvolver talentos para introduzir as mudanças desejadas das condutas, valores e estilos de vida e para suscitar o apoio público às mudanças contínuas e fundamentais que serão imprescindiveis a que a humanidade possa modificar sua trajetória, abandonando a via mais comum que leva a dificuldades cada vez maiores e a uma possível catástrofe, para iniciar o seu caminho em direção a um futuro sustentável. A educação é, em síntese, a melhor esperança e o meio mais eficaz que a humanidade tem para alcançar o desenvolvimento sustentável. (UNESCO, 1999; p.35).

Quanto mais amplo é o sentido da educação, mais abrangente se torna também o sentido do termo educador, que, como sugere a declaração programática Educação 21, do Reino Unido, citada em (UNESCO 1999; p.34), incluirá não apenas os professores do ensino formal, mas também uma série de outras categorias como educadores comunitários, conferencistas, membros de associações de pais, representantes estudantis, especialistas em educação de ONGs, entre tantos outros.

Em suma, pode-se considerar um educador, todo cidadão que se sinta capaz e disposto a assumir essa tarefa de informar e construir com o outro o conhecimento sobre a importância de se cultivar valores e atitudes propícias para a edificação de um futuro sustentável. Essa tarefa é imprescindível para gerar um processo de conscientização nas sociedades com força suficiente para influir nos planos e nas políticas governamentais em favor de um desenvolvimento que contemple em primeiro lugar a qualidade de vida, levando em conta não somente as necessidades materiais básicas dos indivíduos nas diferentes populações, mas principalmente a capacidade do Planeta de supri-las sem ultrapassar a sua capacidade de renovação e de equilíbrio ambiental. 
Como a UNESCO (1999, p.37) enfatiza, "o surgimento do interesse e da compreensão públicos são, ao mesmo tempo, conseqüências da educação e das influências que se exercem por meio do processo educativo". Os currículos do sistema público de educação poderiam ser alterados para atender, de forma mais eficaz, as demandas de uma sociedade sustentável. Para isso, bastaria uma população bem informada e conscientizada, exigindo que o poder público tomasse essa direção. Da mesma forma, alunos bem formados nessa linha, estariam em condições de exigir dos governos, planos preventivos contra a degradação ambiental dentro dos projetos de desenvolvimento. Não resta dúvida, portanto, que a educação é um instrumento fundamental para sustentar a conscientização, a mobilização e a transformação na busca por uma sociedade sustentável. Por esse motivo, é que a sociedade atual deve ter uma preocupação especial e vigiar continuamente os sistemas públicos de ensino, pois, como sugere a UNESCO (1999), da maneira como se encontram hoje, eles não correspondem às essas expectativas. É preciso dar prioridade máxima à melhoria da qualidade do ensino, à ampliação do acesso à educação e à reorientação dos seus objetivos frente ao desafio de se alcançar um futuro sustentável.

Para GADOTTI (2000), diante da crise ambiental que já atravessou o milênio, é preciso pensar a educação do futuro e para tanto, questionar sobre as categorias que podem explicá-la. Segundo ele, as categorias "contradição", "determinação", "reprodução", "mudança", "trabalho" e "práxis" deverão aparecer como uma possibilidade de pedagogia da práxis na educação. O autor acredita que essas categorias, consideradas clássicas se apresentam como importante referencial para nossa prática, tanto no momento de leitura do mundo atual, quanto na compreensão de uma educação para o futuro. Segundo ele, a fenomenologia hegeliana privilegiada por Marx tem forte influência na educação atual e tende a manter-se ainda por muito tempo.

O referido autor acrescenta que apesar da educação popular e da pedagogia da práxis, lidas de forma crítica se perpetuarem pelo próximo século, novas categorias para explicitarem a realidade deverão surgir, e estas não o farão de forma idealista, mas a partir do processo de sua própria leitura. 


\section{1 - Construir um Saber Ambiental e a Participação Cidadã: Princípios Básicos para Sociedades Sustentáveis.}

As discussões apresentadas até aqui permitem afirmar que nenhuma mudança radical pode de fato acontecer no cerne da sociedade atual se não houver primeiramente, um interesse público pelas questões ambientais. Este, não será motivado apenas pelas percepções instintivas das transformações negativas que estão ocorrendo no ambiente e dos riscos que se multiplicam em decorrência delas, mas também por um processo amplo de educação que possa gerar conhecimento e viabilizar a abertura de mais canais democráticos a fim de incluir e ampliar a participação da população quer na geração de idéias para novos estilos de vida menos impactantes, quer na gestão do desenvolvimento dessa outra sociedade que se pretende construir.

Nesse sentido, o saber ambiental se apresenta como um meio para completar o conhecimento da realidade existente bem como para embasar o surgimento de uma organização social diferente das projeções que temos hoje para o futuro, como afirma LEFF (2001). O saber ambiental, para o referido autor “(...) busca apreender os efeitos sincrônicos e sinergéticos que surgem da articulação de processos naturais e sociais, incomensuráveis e irredutíveis aos valores do mercado (p.233)." Ele também dialoga com os diversos saberes e articula as ciências existentes, ao mesmo tempo em que possibilita o nascimento de novas idéias e teorias, que por sua vez serão responsáveis por novas solidariedades e sentidos, capazes de desencadear ações sociais inspiradas na racionalidade ambiental.

A teoria e a prática se relacionam nesse saber, que tem como principal meta a conquista da qualidade de vida do povo. Ele favorece a apropriação subjetiva e coletiva do conhecimento de forma a impulsionar a participação da população nos processos decisórios, livre da manipulação e alienação promovida pelo mercado e pelas leis científicas, colocando na mão do cidadão a oportunidade de participar da produção e gestão do desenvolvimento sustentável e de seus projetos de vida (LEFF, 2001).

Torna-se também bastante oportuna a reflexão de BRIGGS (2000), para quem a construção de uma sociedade sustentável requer o questionamento prévio sobre quem 
toma as decisões e o modo como elas são tomadas. Igualmente PRINTES (2004) acredita que numa sociedade sustentável, deve haver um amplo compartilhamento de responsabilidades e de poder, de tal forma que o número de indivíduos habilitados para a tomada de decisões possa seja cada vez maior. Não é um processo simples, pois não se trata apenas de informar as pessoas, como também lembra PELICIONI \& PHILIPPI JR (2002), pois a informação é importante, mas sozinha não gera transformações, nem tampouco soluciona os problemas que divulga. É preciso, portanto, que os sujeitos das comunidades sejam sensibilizados e este é um caminho lento e paciente, que recebe o nome de "educação".

A educação deve ser movida pela esperança e de maneira especial a educação ambiental (EA) deve estar totalmente imersa nessa missão. A construção de sociedades mais justas, solidárias, equilibradas e saudáveis, requer uma educação, que seja de fato, voltada para a construção da cidadania. Uma cidadania que nasça de uma reflexão coletiva nas sociedades existentes, que possa disparar o desejo coletivo de mudança, sonhado e alimentado, primeiramente, no âmago de cada indivíduo.

Esse desejo encontra respaldo no otimismo de MORIN (2002, p.72), que reafirma a necessidade de se confiar na capacidade criativa dos seres humanos para que neste terceiro milênio se realize uma "nova criação", nascida das sementes do século XX, que o autor chama de "cidadania terrestre". Assim como ele, é importante reconhecer que esta é "a nova missão da educação".

\section{2 - A Importância da EA - Qual EA?}

Quando são discutidos o papel e os desafios que aguardam a educação global, é difícil dissociar a EA desse processo, em virtude de todos os valores que estão agregados a ela. Isso é bem definido por TOZZONI-REIS (2004, p.147), conforme verifica-se a seguir:

(...) se a educação é mediadora na atividade humana, articulando teoria e prática, a educação ambiental é mediadora da apropriação, pelos sujeitos, das qualidades e capacidades necessárias à ação transformadora responsável diante do ambiente em que vivem. Podemos dizer que a gênese do processo educativo ambiental é o movimento de fazer-se plenamente humano pela 
apropriação/transmissão crítica e transformadora da totalidade histórica e concreta da vida dos homens no ambiente.

REIGOTA (2001) também chama a atenção para a necessidade de uma EA que fortaleça a cidadania não para um grupo em particular, mas para a população como um todo, convertendo cada cidadão em ator co-responsável na defesa da qualidade de vida. $\mathrm{O}$ contexto mundial exige o respeito às diferenças, à solidariedade e outros valores positivos que serão proporcionados por um processo onde o diálogo e a interação de todos sejam a marca de suas práticas.

Essa Pedagogia Dialógica enfatizada pelo autor e que tem como principal expoente Paulo Freire, recebeu preciosas contribuições de Habermas, Moscovici, Piaget, Rawls e Vigotsky. Ela confere à participação cidadã a missão de interferir diretamente nos processos de elaboração das micro e macro políticas no plano ambiental dentro da "nova (des)ordem mundial" (p.26).

REIGOTA (2001) considerando o termo "cidadãos alertas" criado por Moscovici e "minorias ativas" de autoria de Nozick, discute a possibilidade de construção de uma sociedade civil forte frente ao Estado a partir da existência desses indivíduos, o que permitiria à Pedagogia Dialógica a realização do seu trabalho de enfrentamento das maiorias e daqueles que preferem manter o status quo. Apesar disso, como o autor salienta, ela é apenas uma das estratégias de luta que nem pretende formar "uma casta de iluminados" e nem tem a pretensão de resolver sozinha todos os problemas ambientais existentes. De qualquer forma, a autonomia da sociedade civil em relação ao poder do Estado fortalece a cidadania e por isso, deve ser defendida pela EA que deseja provocar mudanças na sociedade em direção a uma perspectiva mais ecológica. Esse raciocínio pode ser perfeitamente ilustrado por LEIS (1992), quando afirma que: "Cometeríamos um lamentável erro se confiássemos a gestão de políticas de meio ambiente e desenvolvimento apenas à consciência e vontade dos atores do Estado (governo) e do mercado (as multinacionais)".

No entanto, como alerta MEIRA (2005, p.271) acerca da percepção da população ocidental sobre os problemas ambientais, também "os níveis de conhecimento e consciência são, em geral, bastante elementares e não geram mudanças substanciais nos estilos de vida ou nos comportamentos relacionados com a tomada de 
decisões (o voto, a participação em grupos ambientalistas, a demanda ativa de mudanças nas políticas ambientais, etc)". A grande quantidade de informações científicas disponíveis que circulam em diferentes meios não garante a incorporação de conhecimentos e valores necessários para resolver os problemas socioambientais existentes. Por isso, é preciso mais que informar, mas formar e transformar pensamentos e hábitos, papel que cabe a EA em todos os níveis.

Quanto a isso, REIGOTA (2001) acredita que são tarefas da EA, o estabelecimento de uma 'nova aliança' entre a humanidade e a natureza e de uma 'nova razão', que não signifique desta vez, a autodestruição e que alimente a ética nas relações políticas, econômicas e sociais. Gerações e culturas devem dialogar a fim de construir uma tripla cidadania: local, continental e planetária, baseada na mais plena forma de liberdade onde a justiça social se realize num plano global.

A educação ambiental, nesse sentido, carrega em si a própria utopia, quando assume a missão de contribuir para a construção de uma nova ética e de novos valores. Sendo uma forma de intervenção no mundo, ou como diria ANTELO (2004) acerca do próprio ato de educar: uma maneira de desestabilizar o modo de ver e de viver no mundo do outro ser humano, a educação ambiental está carregada da ideologia de quem a pratica, que tanto pode cimentar a ideologia dominante na sociedade, como pode levar ao questionamento da mesma. Assim, como qualquer prática educativa, está embasada em uma concepção de homem e de mundo (PHILIPPI JR \& PELICIONI, 2000), bem como nas relações entre eles. Não pode existir neutralidade na ação educativa (PELICIONI, 2004), cuja intencionalidade deve estar explicitada nos objetivos a serem alcançados e na busca da sua concretização.

Apesar do consenso desses autores em relação ao papel da EA dentro da perspectiva de uma nova sociedade, REIGOTA (2001) salienta que a ela tem sido muitas vezes realizada a partir da concepção que se tem do ambiente, por esta razão ele acredita que o primeiro passo para realizar a EA deve ser a identificação das representações sociais das pessoas envolvidas no processo educativo. MOSCOVICI (1978) foi o primeiro cientista social a utilizar esse termo, que pode ser entendido como um conjunto de princípios, crenças ou pensamentos comuns, construídos a partir da interação entre os indivíduos. Assim, sob uma mesma ótica ou 'senso comum', esses 
indivíduos compreendem o mundo à sua volta e agem para transformá-lo. As representações sociais de meio ambiente surgiram no Brasil por volta dos anos 80, como explica REIGOTA (2001), que foi também um dos pioneiros a publicar trabalhos a respeito. Por existirem diversas definições de meio ambiente no meio científico, nesse trabalho, concordando com o autor em referência, será adotada a sua definição, bem como a idéia de que a noção desse termo é uma representação social:

"Meio ambiente é o lugar determinado ou percebido, onde os elementos naturais e sociais estão em relações dinâmicas e em interação. Essas relações implicam processos de criação cultural e tecnologia e processos históricos e sociais de transformação de meio natural e construído" (p.14).

Os pesquisadores da Universidade Livre de Bruxelas, Ilya Prigogine e Isabelle Stengers, são freqüentemente lembrados por REIGOTA (2001), por serem autores da obra "Nova Aliança", na qual se propõe o diálogo como uma nova forma de relacionamento entre a ciência e a natureza. Eles se referem ainda a uma "escuta poética" da natureza da qual o homem faz parte e não é apenas um simples observador. Tampouco o estudo da natureza deve se restringir a um mero decifrar de suas leis, pois ela é de fato, muito mais complexa do que se pensa. Nessa proposta, ciência e arte podem dialogar de igual para igual sem, contudo, transformar a ciência em "perfumaria", tornando-a menos neutra e menos objetiva, como temem os cientistas mais conservadores. Essa proposta está, portanto, alinhada com os propósitos de uma nova racionalidade para um novo tipo de sociedade, conforme defesas anteriores neste trabalho ilustradas por diversas outras citações.

A educação ambiental baseada nessa concepção de ciência se preocupa com outras realidades, normalmente desvalorizadas pela educação tradicional, que ignora "os fatos aparentemente não significativos, banais, não lógicos, não racionais (...)” ou seja, tudo o que não está sujeito às normas e regulamentos como salienta Carvalho (citado por REIGOTA, 2001; p.19). Elas se configuram como um terreno fértil para semear novas visões e conhecimentos necessários para reelaborar as representações sociais inicialmente identificadas e que careçam de clareza e complexidade. Conhecer e compreender essas representações é para este autor, condição necessária para tornar possível a negociação e a solução dos problemas ambientais. 
Um outro trabalho enfocando as relações homem-natureza realizado por TOZONI-REIS (2004) pode contribuir para a compreensão da EA que aqui se propõe. A autora discorre sobre a epistemologia da educação ambiental e as concepções de sujeito na relação homem-natureza.

Segundo ela, existem basicamente três concepções de sujeito que revelam as diferentes tendências da relação supracitada: Na primeira concepção, o homem, visto como "sujeito natural", é apresentado como apenas mais um integrante da natureza, onde cada elemento tem o mesmo valor. Entretanto, ele é o causador de todo o mau e precisa retornar às suas origens ("paraíso perdido") para encontrar a felicidade e o equilíbrio perdidos. É uma forma romântica de ver o homem e a própria natureza e relembra o que foi discutido com BOFF (1983) e BAUMAN (2000), acerca da volta ao passado em busca da normalidade e também a um dos tipos de utopia a que se refere MANNHEIM (1986), a utopia dos conservadores, que lutam para preservar os valores e a ordem do passado. TOZONI-REIS (2004) observa que neste caso, tanto os problemas, como as soluções passam pela vontade do indivíduo.

Na segunda concepção, o conhecimento ocupa o centro da relação homemnatureza, na medida em que para preservar basta conhecer, como se os recursos naturais precisassem ser "decifrados cientificamente" para potencializar cada vez mais a sua exploração, num processo infinito. Novamente, retornando ao raciocínio de BAUMAN (2000), essa forma de encarar as crises era comum nas gerações mais antigas, que acreditavam que a solução de qualquer problema passava primeiramente pela aquisição de mais conhecimento e técnica: "o conhecimento pleno, uma vez alcançado, significaria sem dúvida o fim das crises" (p.150), mas não seria tão eficaz nos dias de hoje, tempos imprevisíveis onde as respostas não estão tão prontas e não costumam ser tão impecáveis, como bem lembra o autor.

$\mathrm{Na}$ terceira abordagem, a relação é marcada pela intencionalidade dos sujeitos que estão imersos nos contexto histórico, social, político, econômico e cultural. Portanto, nessa concepção não se fala em homem-natureza, mas em sociedade-natureza. Como observa a autora, a principal idéia é que as relações sociais respondem pela origem dessa concepção: 
(...) a história e a cultura são condicionantes e mediadoras, conferindo-lhe um caráter sócio-histórico. $O$ desenvolvimento da tecnologia aparece como um dos instrumentos dessa relação, pois exige a intencionalidade dos sujeitos para conservar ou impactar, estabelecendo uma relação direta e mecânica, mas definida pela vontade intencional - portanto histórica - dos sujeitos. (p.34).

Em síntese, essas concepções poderiam ser classificadas como natural, racional e histórica, onde no primeiro caso, a posição do homem é definida pela natureza e à educação ambiental cabe reintegrar o homem à natureza e assim, adaptá-lo à sociedade. No segundo caso, figura a razão como ponto central e a educação ambiental deve cumprir o único papel de transmitir informações e adquirir conhecimentos técnicocientíficos. No último caso, a relação homem-natureza é construída pela história social e a educação ambiental tem a função de instrumentalizar os sujeitos para uma prática social ecológica e democrática, capaz de derrotar a alienação, a exploração dos homens pelos homens e a mercantilização da natureza (TOZONI-REIS, 2004). É essa educação ambiental que interessa a esse trabalho e que se espera encontrar em prática nas nossas escolas e nos demais espaços da sociedade. 


\section{5 - A ESCOLA E A AUTONOMIA: O ESTADO, A SOCIEDADE CIVIL E O MERCADO ORIENTANDO AS PROPOSTAS EDUCACIONAIS}

A escola não é uma célula isolada da sociedade, nem tampouco do Estado, por isso, sofre a interferência destes, ao mesmo tempo em que, dado ao seu caráter formador, também é capaz de influenciar nos destinos de ambos. Por esta razão, é interessante refletir sobre esta tríplice relação, mesmo que sem a pretensão de esgotar o assunto, para saber como essa instituição se comporta, construindo ou desconstruindo valores a partir das diretrizes que emanam de fora para dentro (governo/sociedade) e do seu próprio interior recheado de culturas, identidades, necessidades e desejos.

Considerada como principal espaço de educação formal, a escola pública encontra-se naturalmente "impregnada" do Estado, uma vez que ela é apenas mais uma das terminações da extensa e complexa malha de instituições que o representam e sendo assim, também se encontra involuntariamente atrelada aos governos que nele se assentam. Portanto, ainda que para alguns, as Unidades Escolares (U.E.s) pareçam respirar em uma atmosfera particular onde gozam de 'certa autonomia', na prática a mão do Estado, nem sempre visível, está presente em diferentes situações, como por exemplo, na elaboração e implantação das macro-políticas educacionais, cujos responsáveis pela coordenação, implementação e supervisão são os órgãos técnicos mais próximos das U.E.s.

A palestra proferida pela pesquisadora iraniana Nastaran Kesharvarzmohammadi e intitulada "The School as a Complex Adaptative System: a New Conceptualization of the Health Promoting School", por ocasião da $19^{a}$ Conferência sobre Promoção e Educação em Saúde da União Internacional para a Promoção e Educação em Saúde, ocorrida em 2007, no Canadá, colaborou para a reflexão sobre os sistemas complexos de organização das escolas presentes nas diferentes partes do mundo. Elas são feitas de diversos subsistemas, pertencem a uma série de supra-sistemas e interagem com sistemas paralelos, com regras, políticas, currículos, planos de gerenciamento, metas organizacionais que limitam sua autonomia e, portanto, suas ações. Falta, entretanto, uma maior compreensão sobre os sistemas adaptativos complexos das escolas e, portanto, da diversidade de contextos presentes nelas, o que seria importante tanto para 
definir políticas educacionais 'menos homogeneizantes', quanto para avaliar os seus resultados em cada um desses diferentes contextos.

As diretrizes que emanam do poder público e que podem visar a estrutura organizacional da escola e/ou a sua face pedagógica, esbarram, muitas vezes nas visões de mundo e nas concepções de educação dos educadores. Estes podem contribuir tanto para o sucesso, quanto para o fracasso de determinadas políticas governamentais, já que se encontram na ponta do processo, ora como objeto dessas políticas, ora como seus agentes executores nas salas de aula.

Deste modo, a postura dos educadores da escola que é, em todos os casos, uma postura política, pode ser: de 'cooperação voluntária', quando suas aspirações encontram-se sintonizadas com as diretrizes de uma gestão; de 'cooperação involuntária', quando o grupo-escola, embora não seja indiferente, sente-se impotente diante do poder governamental e as cumpre por obrigação; contrária a estas duas posturas, há ainda a posição de 'resistência', quando dentro de suas possibilidades restritas de autonomia, os educadores encontram uma forma alternativa, descumprindo exigências que se contrapõem à ideologia dominante em seu interior. Essa 'desobediência' pode ser velada, (quando a escola trabalha na prática dentro de uma linha divergente da oficial, mas 'teoricamente', do ponto de vista documental, apresenta-se como parte harmônica dentro do sistema) ou explícita, quando a posição daquele grupo encontra respaldo na Rede e através dos sindicatos, torna públicas suas divergências, atuando contrariamente às regras ou orientações estabelecidas.

Poderia ser ainda identificada uma quarta posição, que aqui será chamada de 'simples oposição'. Ao contrário da 'resistência', não está baseada em um processo reflexivo e em um posicionamento crítico. Surge em decorrência de um senso comum, que em algumas situações, é fortalecido intencionalmente por lideranças que compõem o quadro de professores ou das equipes técnicas, por considerarem como negativa, qualquer intervenção externa na rotina escolar. A eloqüência das falas e o poder de convencimento que essas lideranças têm, resultam muitas vezes, na falta de engajamento do grupo em determinados projetos, mesmo quando nem foi dado a estes o 
tempo necessário para avaliarem e formarem uma opinião mais consistente a respeito. São posturas contrárias à politização da comunidade escolar, pois se valem justamente da alienação política e da falta de senso crítico dos indivíduos para defender interesses particulares, impedindo a transformação do sistema educativo e colaborando para a sua ineficiência, ainda que este já não atenda às expectativas da sociedade e nem mesmo as dos próprios educadores da escola.

A partir das duas últimas décadas no Brasil, a educação vem ocupando um lugar de destaque nos discursos políticos, nas propostas governamentais ainda nas preocupações e proposições da própria sociedade civil. Para GOHN (2001), esse destaque nunca antes observado e que se acentuou no final da década de 1990, não trouxe mudanças concretas, mas ainda assim, adquiriu legitimidade por ter aglutinado idéias e reivindicações dentro do senso comum que se criou. Como a referida autora afirma, é importante registrar que as reformas e propostas educacionais sempre obedecem a um ciclo de acontecimentos na história do país com datas e períodos específicos para acontecerem, quais sejam: crises na economia, mudanças no modelo de acumulação existente e o surgimento de novos atores sociais protagonizando o cenário político nacional.

Fazendo uma retrospectiva das décadas anteriores a de 1990, GOHN (2001) relembra que, dos anos 20 aos anos 90, as reformas educacionais sempre estiveram atreladas às demandas da sociedade e dos poderes constituídos naquelas determinadas épocas. Assim, entre os anos 60 e 70, as reformas foram conduzidas pelas cúpulas do regime militar, com o objetivo de atender às exigências da política econômica voltada para o capital internacional, por outro, a desorganização do crescimento da educação formal, a burocratização e o declínio de sua qualidade forçaram na década seguinte o reaparecimento de novas formas de educação não-formal, conduzidas por grupos sociais engajados em movimentos e associações populares. Já na década de noventa, amparada por uma nova Constituição, a sociedade passou a reivindicar seus direitos, buscando uma cidadania até então lhe negada, alimentada por um sentimento de “(...) descrença generalizada na política, nos políticos e nos organismos estatais" (p.8). Porém o grande trunfo dessa década foi o surgimento de pequenos grupos organizados desenvolvendo práticas coletivas, solidárias e contraditórias, cujos efeitos atingiram a sociedade e até 
mesmo o próprio Estado, questionando o status quo e estabelecendo no presente o compromisso com a construção de uma sociedade futura melhor, centrada na missão de desintegrar as bases consumistas vigentes e estabelecer uma nova qualidade de vida.

GOHN (2001, p.9), continuando sua análise, acrescenta que uma nova ameaça surge no cenário educacional brasileiro no final do século $\mathrm{XX}$ : "as políticas de caráter neoliberal, engendradas com o auxílio de forças internacionais, objetivando priorizar interesses de capital monopolista (...)". Também em uma publicação da Secretaria Municipal de Educação de São Paulo (SÃO PAULO, 2001a) salienta-se que essas políticas visam a des-responsabilização progressiva do Estado em relação ao financiamento da educação pública, operando de forma perversa a centralização das orientações educacionais, padronizando o conhecimento a ser produzido nas escolas, e também o sistema de avaliação, como igualmente afirma SCOCUGLIA (2006). Esse movimento centralizador tem como principal intenção promover o acesso diferenciado aos níveis de conhecimento de acordo com a posição social das crianças e jovens, que "aos olhos dos defensores desse ideário, não terão lugar no mundo dos direitos porque entendem não haver mais possibilidade de garanti-los a todos (SÃO PAULO, 2001; p.8)". Nesse sentido, SCOCUGLIA (2006) lembra que a Pedagogia Freiriana é o grande contraponto do ponto de vista teórico e prático a essa forma de pensar a educação.

GOHN (2001), por sua vez, demonstra sua preocupação com a adesão de parte da população a quem ela chama de "minimamente informada e mal informada" pela televisão a esse projeto de educação que acaba sendo convencida de que a presença do Estado é desnecessária na sociedade, mas contraditoriamente reivindica uma escola pública de qualidade para seus filhos. Nesse mesmo período, ela assinala que novas políticas estatais surgiram sob a denominação de modernizadoras, que elegeram a educação como área prioritária. No entanto, suas ações privilegiavam processos que rendiam grande visibilidade política deixando de mexer de fato na 'ferida', ou seja, os setores estruturais críticos.

No início desse novo milênio, é possível afirmar que a retórica da 'reforma da educação para melhorar sua qualidade' persiste nos discursos políticos. Não impediu, porém que o clima de desilusão e descrença da década anterior se estendesse também para os primeiros anos do século XXI, em virtude da degradação crescente da figura do 
político devido aos recorrentes escândalos de corrupção envolvendo governos e partidos políticos na história recente do país e também do insucesso das inúmeras políticas criadas para melhorar o ensino.

Por serem igualmente oportunas as análises de SILVA (1995), SANTOMÉ (2001) e APPLE (2006), acerca do cenário escolar em tempos de neoliberalismo no contexto mundial estas serão aqui aproveitadas para lançar luz sobre as situações que envolvem as instituições de ensino também no Brasil e conseqüentemente, as práticas educativas. Os autores em questão chamam a atenção para a influência incontestável que os mecanismos econômicos e financeiros globais exercem sobre os planos sociais e políticos dos países, incidindo conseqüentemente sobre os sistemas educativos, com uma força proporcional à dependência desses países em relação aos mesmos.

SILVA (1995), por exemplo, designa de 'nova direita', presente em diversos países na atualidade, à combinação do neoliberalismo econômico com o neoconservadorismo moral, que tenta se contrapor às conquistas das classes menos favorecidas e dos movimentos sociais através da educação, intervindo nos currículos para que estes atendam à ideologia do mercado.

Para APPLE (2006, p.13), a conjugação de um discurso supostamente contraditório de competição, mercados e escolhas com a prestação de contas, objetivos de desempenho, padrões, testagem nacional e programas de ensino nacional, gera uma situação "em que é difícil ouvir outra coisa". Na verdade, um discurso fortalece o outro e favorece a cristalização de posições educacionais conservadoras na sociedade atual. Para ele, as políticas curriculares provenientes desses movimentos conservadores, que enfatizam o controle rígido dos programas de ensino e testagem, revelam que essas instituições que empregam essa política neoliberal não são absolutamente democráticas, pois não tratam seus funcionários de forma democrática. Sobre o discurso neoliberal "pragmático" de que não há nada a ser feito, a não ser o que já está posto e que chega também às escolas através da implantação de políticas educacionais, FREIRE (2005) sublinha a importância da resistência por parte dos educadores que não devem aceitar o que lhes é imposto, sobretudo porque ao educador progressista cabe ser coerente com a opção pela emancipação dos sujeitos e a ruptura com a ideologia conservadora e autoritária. 
Conforme também afirma SANTOMÉ (2001), em sintonia com os demais autores, o sistema escolar está sendo convertido em um mercado. Assim, as opções ideológicas capitalistas, neoliberais não apenas defendem, mas impõem à educação a condição de um simples bem de consumo. É bastante claro, que essa nova concepção de sistema educativo, afete também o professorado, que viu de uma hora para outra, multiplicar as suas obrigações, em virtude das novas demandas sociais, mas, também da transferência de encargos do poder público para as unidades escolares, sem que houvesse o necessário acompanhamento de recursos humanos, financeiros e formação específica. Entre essas novas demandas, aparecem: a educação sexual, a educação contra as drogas, a educação para o consumo, a educação para a saúde, a educação para manutenção dos patrimônios culturais e ecológicos, entre outros. GASPARINI et al (2005), ressalta que dentro das unidades escolares, por sua vez, os encargos transferidos pelo poder público acabam sempre atingindo a figura do professor que já não realiza apenas aquilo que a sociedade outrora esperava dele: a mediação do conhecimento do aluno. Sua atuação extrapolou a sala de aula e passou a englobar a comunidade, o que exige do professor uma maior dedicação, ainda que a administração escolar não forneça os meios pedagógicos imprescindíveis para o desempenho dessas novas e cada vez mais complexas tarefas. Resta ao profissional buscar, por seus próprios meios, a requalificação necessária para enfrentar essas demandas, mesmo quando esse esforço não é reconhecido e remunerado na sua jornada de trabalho.

O resultado disso, como lembra SANTOMÉ (2001), é que a despeito da carência de recursos já mencionados anteriormente, a escola e mais especificamente os professores são pressionados pela opinião pública a dar conta desses encargos, já que grande parte da sociedade acredita serem estes de exclusiva responsabilidade e competência dessa instituição. Muitas vezes, até mesmo as famílias dos educandos não imaginam os percalços enfrentados no dia-a-dia pela escola inserida em sua própria comunidade. O Estado, na medida em que delega suas responsabilidades para as instituições educativas e essas para seus professores, torna-se cada vez mais invisível e, portanto, torna-se mais difícil imputar-lhe qualquer culpa pelo fracasso escolar.

Trata-se de uma combinação desastrosa, a desinformação dos pais aliada a uma pseudo-autonomia das escolas, pois como também entende o autor, a autonomia dos 
professores e o cumprimento de suas responsabilidades não poderiam estar dissociados de uma boa formação, atualização psicopedagógica e cultural e de recursos econômicos, o que lhes conferiria mais coragem para agir de forma intencional e também para inovar as suas práticas. SANTOMÉ (2001) acrescenta que as condições de trabalho também são fatores essenciais para concretizar o exercício da autonomia. A exemplo do que foi discutido por GASPARINI et al (2005), cita a necessidade da disponibilidade de tempo e de espaços físicos que possibilitem reunir os educadores com seus alunos e famílias, além de uma jornada de trabalho docente que permita aos mesmos discutirem e planejarem o dia-a-dia da escola, através de seus planos, projetos e atividades extraordinárias, bem como os problemas que surgem e que às vezes precisam de intervenções urgentes.

Contudo, o Estado considera que transformar o sistema escolar significa primordialmente investir na mudança da direção dessas instituições. Para SANTOMÉ (2001), trata-se de reforçar a estratégia que sobrepõe à mentalidade da 'cultura empresarial' às culturas tradicionais de colaboração e responsabilidade coletiva, conferindo um papel de manager a esses diretores que estimulam a propagação de valores que fortalecem a ideologia mercantilista. Pode-se dizer que na Rede Municipal de Ensino de São Paulo, já há algumas décadas, modelos de gestão adotados por diferentes administrações políticas e inspirados em outros países, procuram instalar o sistema de "Qualidade Total" na educação, considerando a escola como 'empresa' prestadora de serviços, diretores como 'gerentes' e os alunos/pais como 'clientes'. Nesse sentido, alguns cursos oferecidos ao trio gestor das escolas (diretores, assistentes de direção e coordenadores pedagógicos) têm tido um enfoque maior nessa perspectiva, em detrimento de outras questões inerentes ao processo educacional. Assim, as equipes participantes fornecem planilhas de apontamentos com o mapeamento preciso dos espaços da escola, dos recursos materiais e humanos, quantificando resultados em função de metas traçadas e recebem instruções sobre como 'otimizá-los', melhorando a relação custo-benefício de cada Unidade Escolar. Por outro lado, muitos diretores se sentem desestimulados a continuar nessa função em virtude das dificuldades crescentes que estes apresentam em lidar com procedimentos cada vez mais complexos de prestação de contas (detalhados por meio de portarias, por exemplo) e que exigem, muitas vezes, conhecimentos de áreas específicas, como contabilidade e informática que eles não detêm. Além disso, não lhes sobra tempo para se dedicarem ao 
acompanhamento do processo de ensino-aprendizagem, já que esses educadores passam a ser, a maior parte do tempo, 'gerentes administrativos' da escola.

Também merece crítica a política adotada pela Secretaria Municipal de Educação de gratificações ou bônus. Entre elas está a Gratificação por Desenvolvimento Educacional (GDE), criada pelo governo (2001-2004) e mantida pelo atual governo (2005-2011), porém com algumas alterações, cujos valores variam de acordo com a arrecadação do Município e é paga em duas parcelas - na metade e no final do ano letivo. Dentre os critérios estabelecidos para que os integrantes das escolas a recebam integralmente estão a ausência de faltas de qualquer natureza (abonada, justificada, licenças médicas, e outros afastamentos...) e o cumprimento das metas educacionais estabelecidas no início do ano letivo, com relação à aprendizagem, aprovação, reprovação e evasão dos alunos. As equipes técnicas cabem fiscalizar o atendimento desses critérios de forma rigorosa. É notória a situação de achatamento salarial a que têm sido submetidos os profissionais de educação há muitos anos, por isso há uma forte crítica dos sindicatos quanto a não incorporação desses valores diretamente ao salário dos educadores, bem como ao fato de não contribuírem para melhorar o desempenho das escolas, pois muitos profissionais de educação que se ausentam das escolas o fazem justamente por estarem acometidos de doenças, geralmente adquiridas no exercício de suas funções (ZAGURI, 2006). Outros, por receio de perderem esse benefício, ou por sofrerem pressão da direção, acabam sacrificando sua segurança e saúde (e consequientemente a qualidade do ensino oferecido aos educandos) e continuam em exercício, mesmo sem terem condições de fato de desempenharem suas funções integralmente. Assim os relatórios que a direção e demais membros da equipe técnica escolas enviam regularmente aos órgãos superiores, acerca do processo educacional que está sendo desenvolvido, os resultados obtidos e as condições de trabalho de seu quadro funcional podem não refletir a real situação da mesma porque estas questões não aparecem ou são mascaradas.

Da mesma forma as escolas têm se deparado com uma série de avaliações diagnósticas externas que deveriam auxiliar a escola na escolha dos caminhos mais adequados para resolverem os problemas detectados, mas quando dependem da intervenção dos órgãos técnicos superiores para providências que a já comentada 'restrita autonomia' da direção não permite fazer, como: contratação de professores, 
formação específica, construção de novos espaços pedagógicos, designações de professores para completarem sua equipe técnica, entre outros, esbarram na burocracia e na falta de eficiência desses órgãos.

É importante refletir sobre outra questão relativa aos resultados coletados por meio de tais avaliações sobre cada escola, que quando apresentados de forma comparativa entre as Unidades de uma mesma região ou em relação ao Município, não consideram devidamente os contextos (que certamente não são uniformes), pois os problemas de aprendizagem podem ter diferentes causas: estratégias pedagógicas inadequadas, gestão escolar ineficiente, deficiências no quadro docente, entre outras, mas apresentadas desta forma acabam colaborando para a instalação de um clima de vigilância e competição entre as escolas, o que é contrário ao espírito de cooperação e troca de experiências esperado dentro de uma Rede de Ensino.

Com a ajuda de PARO (2002) será apresentada a seguir, uma análise sobre o cenário escolar atual brasileiro sob a ótica dos trabalhadores. Observa-se, neste caso, que a escola é reprodutora da ideologia dominante, negando os valores dominados e colaborando para as injustiças sociais, ao alocar os indivíduos em posições privilegiadas de acordo com o status econômico que detêm na sociedade. Sobre isso, também concorda SANTOMÉ (2001, p.30), quando se refere a um "sistema educativo credencialista" apoiado em um modelo de sociedade em que é notável a desigualdade de oportunidades, e na qual meninos e meninas têm mais e melhores possibilidades escolares em função de sua origem social (...)". Assim, é preciso que as classes trabalhadoras se apropriem da escola para que ela possa ser de fato transformadora. Para isso, é necessário mexer no sistema de autoridade e na distribuição do trabalho no seu interior. PARO (2002) acusa o sistema hierárquico que se tem hoje, de ser contraditório na medida em que, considera o diretor a autoridade máxima dentro da escola, revestindo-o de grande poder e autonomia, que na verdade não existem, pois ele é apenas um cumpridor de leis e executor das ordens do Estado.

Outro aspecto dessa contradição está no fato de que ao mesmo tempo em que os diretores são 'treinados' para administrar adequadamente os recursos da escola, por supostos métodos e técnicas modernas, o grande problema em questão é saber quais são esses recursos, pois estes não chegam até a escola ou pelo menos não em quantidade 
suficiente para que ela desempenhe eficientemente as funções que dela se espera. Lembrando o que foi dito por SANTOMÉ (2001), as imposições das instituições financeiras internacionais das quais somos reféns há muito tempo, determinam as prioridades de investimento e certamente a saúde e a educação não se encontram entre elas.

PARO (2001) considera que a impotência e a falta de autonomia do diretor se refletem na impotência e na falta de autonomia da própria escola. E esse é apenas o início de uma seqüência que vai terminar na privação do trabalhador a uma forma importante de apropriação do saber e de uma consciência crítica.

Trata-se de conferir poder à escola para que os interesses dos trabalhadores sejam levados em consideração durante o processo educacional, mas isso dependerá não de uma concessão por parte daqueles que detêm o poder, mas da aliança feita com as camadas trabalhadoras para atingir esse objetivo, começando pela reorganização da autoridade no interior da escola. O referido autor prevê que o maior obstáculo a ser transposto é a posição de autoridade máxima que foi "astutamente" conferida ao diretor e mantida pelo Estado, pois essa posição hierárquica promove divisões no seio da escola, influencia negativamente a imagem do diretor e acaba levando-o a tomar decisões parciais, geralmente em detrimento dos dominados, conferindo um aparente poder a ele, que de fato não existe.

Propiciar a participação dos outros segmentos da escola (educadores, alunos, pais, funcionários) na gestão escolar em seus aspectos administrativos e principalmente pedagógicos, não significa destituir o diretor de seu poder, mas dividir responsabilidades. Isso ampliará o poder da escola no sentido de negociar junto aos órgãos superiores, melhores condições de trabalho e de funcionamento para a realização de sua missão institucional. Observa-se que 'a gestão democrática da escola' é um discurso corrente entre as diferentes administrações públicas, mas com poucos efeitos práticos dentro da Rede até hoje.

É o que também discutem GADOTTI \& ROMÃO (2001), lembrando que “a autonomia e a gestão democrática da escola fazem parte da própria natureza do ato pedagógico" (p.35). Para eles, o projeto político-pedagógico e a gestão democrática são 
elementos inseparáveis porque o primeiro exige a existência do segundo, já que deve ser elaborado e realizado coletivamente. $\mathrm{Na}$ gestão democrática, todos os segmentos da comunidade escolar conhecem e assumem as suas responsabilidades para a concretização do projeto da escola e não há duas escolas iguais, portanto, seria arrogante demais esperar os mesmos resultados dos projetos das escolas inseridas dentro de um sistema educacional, conforme foi lembrado anteriormente pela pesquisadora Nastaran sobre os diferentes contextos onde estas estão imersas.

Para GADOTTI \& ROMÃO (2001), ainda, a luta pela autonomia não se restringe à escola, mas está dentro de uma luta maior que é a autonomia da própria sociedade. Assim, seria "a luta dentro do instituído, contra o instituído, para instituir outra coisa" (p.47). E nessa luta, cada escola só sairá vitoriosa se, além de pensar o novo, experimentá-lo sem medo. Os autores alertam, no entanto, que é preciso construir gradativamente um estado de confiança na escola quanto à sua capacidade de tomar nas suas próprias mãos a resolução de seus problemas e autogovernar-se.

A democratização das relações no interior da escola abre uma nova frente de discussão: como deve ser o currículo dentro dessa perspectiva de inclusão e busca de autonomia dos atores educativos para criar ou fortalecer uma cultura cidadã? 


\title{
6 - CURRÍCULOS X CURRÍCULOS: OPÇÃO IDEOLÓGICA
}

\begin{abstract}
Houve um tempo em que o fazer da escola estava pautado em um plano. Esse plano dividia o curso em série e cada série tinha um programa a cumprir dentro de cada área, e não importava se chovia ou se fazia sol, se o menino apanhava, chorava, comia ou sofria, ou mesmo porque sorria, o importante era cumprir o programa. E ano após ano esse plano era copiado e aplicado...

Mas as árvores foram cortadas, os rios foram poluídos, as crianças foram violentadas em seus direitos mais básicos, e os jovens que não puderam falar, buscaram em seu solitário monólogo outras formas de se expressar.

As famílias se reorganizaram, se reestruturaram. Continua-se comemorando o Dia das Mães e o Dia dos Pais, porém muitos jovens nem sequer os conheceram. Fala-se do Natal, dos presentes para quem nunca abriu um pacote. Tanta coisa aconteceu, mas, afinal, havia um programa a cumprir. (SÃO PAULO 2001, p.8)
\end{abstract}

DOLL JR. (1997) seguindo o caminho já revelado anteriormente nesse trabalho por outros autores, analisa o século $\mathrm{XX}$ e as consequiências da racionalidade que prevaleceu sobre o sentido da nossa própria humanidade, citando como algumas das falências decorrentes, a social, a política, a ecológica e a humana. Segundo o autor, para “criar a quantidade certa de tensão essencial necessária aos curricularistas, professores e alunos, bem como líderes mundiais e comunidades" (p.172) seria preciso que houvesse um equilíbrio entre o excesso de fé e a escassez de dúvidas. Só essa "mistura paradoxal", como designa o autor, poderia garantir um futuro melhor do que temos hoje vislumbrado a partir do presente que vivemos.

DOLL JR. (1997), acredita que o currículo é o processo no qual o diálogo e a reflexão são imprescindíveis para a aprendizagem e o entendimento e ele não é transmitido, é construído na medida em que negociamos. $\mathrm{O}$ autor afirma que:

(...) num relacionamento reflexivo entre professores $e$ alunos, o professor não pede ao aluno que aceite a autoridade do professor; pelo contrário, ele pede que o aluno suspenda a descrença nessa autoridade, reúna-se ao professor na investigação, naquilo que o aluno está experenciando. $O$ professor concorda em ajudar o aluno a compreender o significado dos conselhos dados, em estar 
pronto a ser confrontado pelo aluno e em refletir com o aluno sobre o entendimento de cada um. (p.175, 176).

Visando compreender melhor o conceito de currículo, será aproveitada, em um primeiro momento a contribuição de GOODSON (1995) a respeito da origem dessa palavra. O referido autor lembra o termo 'currículo' vem do latim scurrere, que quer dizer 'corrida', portanto nos remete a idéia de um curso a ser seguido ou apresentado. Em que pesem as incorrências etimológicas do conceito revelado, optou-se por adotar aqui uma outra visão de currículo, menos limitante e mais palpável, já que não se reduzirá a um manual de conteúdos e metodologias a serem seguidos.

Nesse sentido, também ALMEIDA (2002) traz importantes informações sobre a história do currículo dividida em diferentes momentos de acordo com as referências que lhe eram atribuídas. De forma sintética, esses aspectos serão abordados aqui para auxiliarem na escolha de uma definição de 'currículo' que se aproxime da proposta emancipadora de educação defendida nesse trabalho.

Reportando-se à Grécia antiga de Platão e Sócrates, a autora, apoiada nos estudos de Terige, lembra que, nesta época, o currículo era visto como 'um conjunto de temas a serem ensinados', apresentados não como uma lista, mas como uma descrição. Já em torno do século XVII, com base em uma nova definição dada pelo Oxford English Dictionary de 1633, o currículo passa a ser entendido como 'uma forma de se manter a ordem e a disciplina' para reforçar a estrutura escolar anglicana. Já no início do século $\mathrm{XX}$, pela primeira vez ele adquire um sentido intencional, com conotação política, pois passa a estar a serviço de uma sociedade industrial, com um instrumental didático próprio e uma metodologia de avaliação. Essa concepção de currículo, segundo a referida autora, perdurou até próximo aos anos setenta do século XX, quando então, as discussões acerca desse tema se avolumaram no sentido de se buscar novas possibilidades de interpretação do mesmo. Essas discussões persistem até os dias de hoje, em virtude do grande peso que esse tema tem dentro de uma discussão maior, que é o papel da educação na construção de uma nova sociedade. 
No trabalho de ALMEIDA (2002; p.14-15) podem ser encontrados os principais paradigmas para produção teórica curricular, criados por James B. Macdonald e traduzidos por Domingues:

- O paradigma técnico-linear, surgido nos EUA, no século XX, cujo foco era a formação de mão-de-obra para suprir as necessidades das indústrias;

- O paradigma circular-consensual, que enfatizava os estudos sobre linguagem e interpretação e se preocupava principalmente com a interpretação da história do indivíduo. Ele surgiu na Europa e nos EUA, na década de 1970, a partir dos movimentos estudantis que desejavam novos rumos para a educação, até então, vinculada ao paradigma anterior. Essa nova visão de currículo dá aos alunos novas perspectivas de interpretação dos fatos e sentimentos por ele vividos, permitindo a experiência e o questionamento da experiência.

- O paradigma dinâmico-dialógico reforça a idéia da 'não neutralidade' do currículo, já assumida pelo paradigma anterior e, portanto, do seu caráter ideológico, com a perspectiva de transformação social, com opção clara pela emancipação das camadas populares, sustentado por categorias como poder, emancipação e crítica.

ALMEIDA (2002; p.16) explica que o pensamento curricular brasileiro segue duas orientações baseadas nesse último paradigma: a "pedagogia crítico-social dos conteúdos", na qual os conteúdos retomam uma posição destacada, bem como o papel essencial da escola como transmissora de conhecimentos; E a "educação popular", comprometida com o pensamento de Paulo Freire, que enfatiza a importância da construção de uma consciência crítica no educando, partindo da valorização da sua cultura para desenvolver no mesmo a sua "capacidade de resistência e seu poder de luta".

Na concepção de APPLE (1997; p.210), um dos expoentes do paradigma dinâmico-dialógico já exposto, currículo é “(...) um processo complexo e contínuo de 
planejamento ambiental", porque não se configura como um programa de curso, mas trata-se de “(...) um ambiente simbólico, material e humano que é constantemente reconstruído". Nesse sentido, é preciso planejá-lo com a preocupação de atender aos seus diversos aspectos: técnico, estético, político e ético a fim de que possa cumprir sua função no plano individual e social. A ênfase dada a esses aspectos revela a profunda identidade com o pensamento e o trabalho desenvolvido por Paulo Freire, como será apresentado a seguir:

Quando o autor se refere ao currículo como "um ambiente simbólico, material e humano", ele está lembrando que, no plano material, as instalações da escola, seus equipamentos e até o seu entorno são elementos carregados de significados que podem favorecer o processo de educação, assim como os seres humanos que ali convivem e desenvolvem suas diversas relações e produções (ALMEIDA, 2002).

Quando inclui o aspecto técnico em sua definição de currículo, APPLE (1997) ressalta a importância da aplicação do que se poderia chamar de 'um conjunto de procedimentos e normas orientados para realizar eficazmente uma determinada atividade', mas numa perspectiva freireana. Neste caso, a ética permeia a sua escolha e o seu emprego para cumprir uma função claramente definida, qual seja a de levar o educando de um estágio de consciência ingênua à consciência crítica (ALMEIDA, 2002). Da mesma forma, o aspecto estético igualmente acentuado, representa "(...) o fascínio e o encantamento inerentes à posse do conhecimento ética, política e ideologicamente a serviço do ser humano" (p.31), tornando-se um elo entre a cultura científica e popular e o educando. Quando ao aspecto ético, que como se percebe está embutido nos demais aspectos e também é um dos fundamentos da teoria pedagógica de Paulo Freire, dele não pode prescindir a transformação dos sujeitos e da sociedade.

(...) para Freire, a prática educativa, da qual o currículo é uma expressão, só tem validade se interferir na materialidade das instâncias ético-políticas que orientam a vida do educando, criando nele a consciência de sua capacidade de, ainda que na condição de vítima de um sistema opressor, reconstruir a própria materialidade do seu cotidiano, fazendo surgir novos 'facta' para a re-elaboração de uma nova materialidade ética e, conseqüentemente de uma nova moral (ALMEIDA, 2002; p.41). 
Portanto, APPLE (1995), assim como Paulo Freire, reconhecem que o currículo jamais será um conjunto neutro de conhecimentos e a educação jamais será apolítica, pois estão a serviço de alguém. A decisão para escolher como 'mais legítimos' determinados conhecimentos, de modo que se tornem 'oficiais' em detrimento de outros, revela exatamente quem tem o poder na sociedade.

Essa visão é compartilhada por SILVA (1996), pois para ele, saber e poder são inseparáveis numa perspectiva foucaultiana, assim como currículo e poder estão intimamente ligados, não apenas pelo fato de que o conhecimento presente no currículo está impregnado da ideologia dominante (poder), que deseja conhecer para melhor governar os corpos e as mentes, mas também porque o "o poder está inscrito no currículo" (p.167), através da divisão dos saberes, que determinam o que é e o que não é conhecimento, o que inclui e o que exclui, o que produz e o que reforça - tudo isso é poder dentro do currículo. Como o próprio autor sugere, essa é a principal razão para opormos o saber ao poder, para barrá-lo, quando isso se faz necessário e é nesse sentido que se constrói um currículo emancipatório ou libertador.

Nas visões de FERRAÇO (2006) e SANCHO (2006), o currículo é tudo o que acontece na escola, constrói-se de forma dialógica e envolve toda a comunidade escolar. A dialogicidade no processo de construção do currículo revela a intenção de descentralizar o poder, normalmente conferido aos 'especialistas', no sentido de propiciar a participação de todos os sujeitos envolvidos no processo educativo, valorizando as suas culturas, seus modos de vida e suas aspirações. Nessa perspectiva, ele pode ser definido como uma:

(...) rede de fazeres e saberes, produzidas e compartilhadas nos cotidianos escolares, cujos fios, nós e linhas de fuga não se limitam a esses cotidianos, prolongando-se para além deles nos diferentes contextos vividos pelos sujeitos que praticam e habitam, direta ou indiretamente as escolas, isto é, professores, alunos, serventes, pedagogos, pais, secretárias, vigias, coordenadores, diretores, membros das comunidades, entre tantos outros. (FERRAÇO, 2006; p.9).

FERRAÇO (2006) concorda com ALVES et al (2002), que não existe apenas um, mas muitos currículos em ação nas escolas, embora estas estejam sujeitas a uma 
organização homogeinizadora. O currículo real, por exemplo, é diferente do currículo oficial ou padrão. Enquanto este último é documental, escrito como uma lista de conteúdos, metodologias e estratégias, o currículo real é "a soma de todo tipo de aprendizagens e ausências que os alunos obtêm como conseqüência de estarem sendo escolarizados", o que pode ser comprovado quando o foco é mais aproximado sobre a realidade escolar e suas práticas cotidianas (SACRISTÁN, 1995; p.86).

Quando se muda o foco de um currículo-padrão, estático, para esse, que está constantemente em ação, pois se constitui a partir das práticas cotidianas das comunidades escolares, reconhece-se imediatamente que, como observou CERTEAU (1996), embora falem dos currículos, os sistemas de ensino não conhecem as escolas e seus sujeitos, por isso desconsideram tanto suas práticas cotidianas, quanto os diversos saberes construídos em seu interior.

SANCHO (2006), ao analisar as mudanças curriculares que estão sendo implementadas em diferentes países da Europa e América Latina, por exemplo, afirma que na maioria delas o resultado é "decepcionante" e só em raras exceções, como no norte da Europa, Austrália e Nova Zelândia, o currículo da escola procura definir o tipo de cidadãos a serem formados, recebendo para isso, os recursos e a autonomia necessários, bem como a definição da responsabilidade real das escolas.

Olhando para as nossas comunidades educativas, formadas por educadores, educandos, funcionários, pais e membros de diferentes instituições presentes nos arredores da escola que também podem interagir com ela, observa-se que a criação e/ou ampliação de mecanismos que incluam outras formas de democracia além da representativa, poderiam viabilizar a participação ativa de todos (especialmente das crianças e adolescentes, frequentemente "sujeitados" dentro do processo educativo) nos momentos decisórios e não apenas na execução de planos e projetos. Abririam espaço para a pluralidade de idéias e identidades, para a negociação e para a distribuição de papéis e responsabilidades na construção de um sonho pedagógico, a priori, específico daquele coletivo, mas que, sem dúvida, seria peça importante num sonho maior, de uma outra sociedade possível. Esse é, portanto, um passo decisivo para dar início à gestação de um currículo emancipatório na escola, que é o avesso do currículo-padrão, aquele que imobiliza e conforma para os modelos de dominação vigentes. Ele estimula, dentro 
do cenário escolar, práticas pedagógicas comprometidas com a formação de cidadãos autônomos, críticos e participativos, capazes de intervir no mundo de forma intencional para transformá-lo e por isso, consideradas como práticas emancipatórias. Tais práticas dentro de um currículo serão assim identificadas na medida em que estiverem comprometidas com a democracia, a autonomia, a rebeldia que se transforma em resistência diante de tudo o que subjuga e aliena. Seus protagonistas, segundo FERRAÇO (2006, p.11), serão todos os sujeitos da comunidade educativa "legítimos autores das possibilidades de intervenção da realidade".

A definição do currículo da escola, por sua vez, está embasada na concepção de sujeito, de sociedade e de conhecimento que é assumida por ela, por isso, SANTOS NETO (2008) alerta que é preciso construir coletivamente uma concepção que seja consensual e clara para embasar as escolhas no processo educativo e que definirão o projeto político-pedagógico.

\section{1 - A Importância da Construção Coletiva do Projeto Político-}

\section{Pedagógico (PPP) e da Definição da Concepção de Educação}

Como afirma GADOTTI \& ROMÃO (2001), o PPP não é meramente um plano diretor da escola, ou seja, um conjunto de objetivos, metas e procedimentos. É, na verdade, um instrumento que confronta o instituído (a história da escola, o conjunto dos seus currículos, dos seus métodos, de seus atores internos e externos e o seu modo de vida) e o instituinte (aquilo que, a partir da revisão do instituído, institui outra coisa). Para eles, o projeto pedagógico da escola é político, na medida em que indica um rumo, uma direção política e por isso não pode estar a cargo somente da direção da escola, mas deve ser construído coletivamente.

SANTOS NETO (2004a; p.8) também reafirma a importância da construção coletiva do PPP, porque é ele quem vai propiciar, entre outras coisas, a elaboração do sujeito coletivo e também avaliar o caminho percorrido pela escola rumo à conquista do sonho 'sonhado' por aquela comunidade escolar. Para isso, ele propõe a reflexão sobre algumas questões acerca do seu processo de construção: 
- Quem somos nós enquanto escola? Qual o contexto em que estamos?

- Que necessidades identificamos nesse contexto? Que tipo de ser humano e de sociedade queremos ajudar a construir?

- Quais diretrizes pedagógicas devemos assumir na prática, para construir nossas intenções educativas?

- Que ações consideramos prioritárias a partir daí?

SANTOS NETO (2008a) reforça também, que quando o PPP é construído de forma democrática, envolvendo toda a comunidade educativa e considerando a diversidade em todos os seus aspectos, os conflitos, quando estão presentes, ao contrário de serem destrutivos, podem auxiliar na edificação de um projeto comum a partir das próprias diferenças. Ele se apóia na descrição do 'sujeito coletivo' de SILVA (1996), para explicar que para que ele nasça dentro de um grupo é preciso que cada indivíduo envolvido nesse processo seja capaz de perceber a sua identidade e como ela foi construída; que não perca a referência de sua própria história; que assuma tarefas comuns e saiba avaliá-las criticamente; que ultrapasse as dimensões relacionais presentes no ambiente de trabalho que se baseiam antes ou acima de tudo, nas antipatias e simpatias; que seus traços mais marcantes o façam ser conhecido pela comunidade maior onde vive e se desenvolve; que tenha capacidade de argumentação; que tenha uma posição política clara dentro da sociedade; que defenda seus objetivos maiores e a união do coletivo, apesar de suas contradições internas.

SANTOS NETO (2004a) traz ainda, uma relevante discussão sobre a necessidade de se identificar dentro da concepção pedagógica (aquela que explicita a intencionalidade do processo educativo), a concepção de ser humano (antropológica) que se defende, de conhecimento (gnosiológica), de sociedade que se deseja (política), de educação escolar construída a partir das anteriores e a concepção de professor e de prática que está diretamente relacionada à concepção de educação escolhida. No entanto, o referido autor conclui que esse exercício de identificação das diferentes concepções não tem sido feito, muitas vezes, durante o processo formativo dos educadores e que desta forma, muitos educadores realizam o seu trabalho sob uma concepção pedagógica que nem mesmo eles conseguem identificar com clareza. 
Portanto, sustenta que é preciso que haja uma reflexão filosófica sobre as práticas pedagógicas a fim de que haja coerência na escolha dos educadores da concepção antropológica que vai definir "um trabalho crítico, consciente e mesmo progressista" (p.6). Segundo ele, as estratégias didáticas só conseguem ser definidas nessa perspectiva explicitada, quando os educadores têm clareza dos princípios fundantes do PPP, com base nas concepções ora discutidas.

\section{2 - O Desafio de Formar Educadores Emancipadores}

O educador não pode se apartar do futuro porque ele é um partejador do futuro e por essa razão não há como se desvencilhar da utopia. Sua paixão pelo futuro é também pela inconformidade das coisas. A escola é lugar ideal para a recusa, para o inconformismo, para a resistência e para o 'não' consciente (CORTELLA 2001). É também espaço para mobilização, que na visão de TORO \& WERNECK (2004, p.13), “(...) ocorre quando um grupo de pessoas, uma comunidade ou uma sociedade decide e age com um objetivo comum, buscando, quotidianamente, resultados decididos e desejados por todos". Os autores também sugerem que "mobilizar é convocar vontades para atuar na busca de um propósito comum, sob uma interpretação e um sentido também compartilhados". Assim, não apenas os professores serão educadores, mas também, os diretores, funcionários da secretaria, agentes escolares, supervisores, coordenadores pedagógicos e alunos, como pensa ALMEIDA (2001; p.3): “Todos temos a delicada, artística e tecnológica tarefa de educar!...” Assim, conforme o autor em referência salienta, a comunidade educativa precisa estar sempre disposta ao diálogo, se pretende ser coerente com o seu papel. É preciso vivenciar através da afetividade, do debate aberto e do respeito, a ética, os valores, o convívio e a liberdade, pois ensiná-los apenas não basta.

Definir o papel do educador na sociedade brasileira na atualidade não é uma tarefa fácil. RIOS (2001) analisa a prática educativa sobre dois aspectos - o que é necessário para desempenhá-la e o que lhe compete para a construção da sociedade, e relembra que ela está dentro de uma entidade concreta; Esta, por sua vez, está inscrita numa sociedade com características próprias e historicamente construída. Além disso, a escola é o lugar da práxis e da contradição, pois contraditórios são também os sujeitos 
que interagem em seu interior, transmitindo e transformando saberes e relações. Portanto, para a autora, se a profissão de educador for entendida como um ofício ou trabalho a ser exercido na sociedade, neste caso ela adquire um sentido de obrigação que deve estar atrelada à competência, ou seja, "saber fazer bem", seguida pela maioria dos próprios educadores e que apresenta uma dupla dimensão: a técnica e a política, indissociáveis e mediadas pela ética. Não é possível fazer política sem competência da mesma forma que de nada vale a técnica sem o compromisso, como afirma Saviane citado por RIOS (2001; p.50), que acrescenta: "a política também é uma questão técnica e o compromisso sem competência é descompromisso".

Assim, o desafio de educar para a emancipação pressupõe educadores emancipadores, que são aqueles dispostos a investir num trabalho pedagógico que não obscureça os mecanismos de dominação, mas os desvele; que ajude a constituir identidades e que gere inconformismo diante das muitas formas de dominação social, buscando alcançar a autonomia (OLIVEIRA, 2006). À respeito disso, RODRIGUES (2001; p.58) recorre ao pensamento de Gramsci: "todo ato educativo deve objetivar, em primeiro lugar formar o cidadão, dando-lhe a capacidade de se tornar governante, isto é, de ser uma pessoa capaz de pensar, estudar, dirigir e controlar quem dirige". BARBOSA (1998) utiliza o conceito "autor-cidadão" para definir um tipo de cidadania que se constrói sob vários aspectos: histórico, geográfico, social, psicanalítico e ecológico e que portanto, exige um sujeito politizado nas diversas perspectivas e não apenas econômica e política partidária.

Também sobre isso se refere GADOTTI e FREIRE (2001), quando discutem sobre o papel do educador. Para ambos, esse papel não pode ser definido de forma estática, imutável. No entanto, numa sociedade de classes, podem ser identificados dois tipos de educadores: o reacionário e o revolucionário. Ambos serão muito mais eficientes se tiverem clareza política da opção política da classe que defendem, por isso seus caminhos são opostos. O primeiro considera o conhecimento como objeto seu e de sua classe. O segundo não deseja controlar o educando pelo poder de deter o objeto, pois ele não se apodera dele, apenas o conhece e deseja desvelá-lo com o educando, trabalhando como sugere Santos, citado por OLIVEIRA (2006, p.32), com imagens desestabilizadoras para gerar esse inconformismo subjetivo que vai desencadear a luta 
pela emancipação e pela democratização das relações sociais em todas as instâncias, inclusive na escola.

Para MEIRIEU (1989), há elementos que podem transformar o magistério em um novo ofício, tais como: a prática reflexiva, a profissionalização, a capacidade de trabalhar em equipe desenvolvendo projetos, o aumento da autonomia e da responsabilidade, as pedagogias diferenciadas, o foco sobre os dispositivos e sobre as situações de aprendizagem e também, a compreensão da relação com o saber e com a lei. PERRENOUD (2000) salienta que, esse novo ofício nasce em meio a uma crise gerada pelas condições adversas de trabalho dos professores, como a falta de recursos financeiros e de políticas favoráveis, por isso muitos deles se fecham em suas salas de aula e nas práticas que segundo os mesmos, costumam dar algum resultado. Outros, porém, a despeito desse cenário desfavorável, preferem lutar contra a maré, por não aceitarem a sociedade dual, construída em cima do fracasso escolar, porque desejam ensinar, acima de tudo e verem seus alunos aprenderem, ou ainda, como afirma HUBERMAN (1989 e 1989a), porque depois de muitos anos no magistério, eles não desejam morrer de pé, com o giz na mão, escrevendo no quadro-negro. Certamente, aqueles que se sentem inconformados com o status quo e por isso se sentem motivados a contrariá-lo, poderão, se insistirem nessa posição, contribuir para a emancipação de seus educandos.

Educadores emancipadores precisam de uma formação que não se baseie simplesmente na utilização mecânica de guias ou manuais, pois tais recursos procedem de uma visão autoritária de educação que escraviza e desrespeita a capacidade criativa, crítica e de autonomia do outro, apostando na domesticação do professor e na reprodução desse comportamento também nos seus educandos (WESTPHAL, 2000), afinal, os erros se repetem. No entanto, essas estratégias são muitas vezes utilizadas pelos programas governamentais de capacitação docente e até mesmo por algumas Universidades, sob o pretexto de estarem investindo na melhoria da qualidade da educação, sem o estarem de fato. Desta forma, professores e alunos são tratados como seres limitados, incapazes de perceber as problemáticas que os envolvem ou de contribuir para a solução das mesmas. São meros reprodutores de conceitos e comportamentos que freqüentemente nada tem a ver com a sua própria realidade e que, portanto, não poderão contribuir para melhorar a qualidade de ensino, nem tampouco 
interferir na realidade para produzir as transformações que se fazem urgentes na sociedade. Se só reproduzem, se não há reflexão, não poderá haverá ação transformadora. Sobre isso FREIRE (2001; p.72) comenta:

\begin{abstract}
Como pode a educadora provocar no educando a curiosidade crítica necessária ao ato de conhecer, seu gosto pelo risco, a aventura criadora, se ela mesma não confia em si, não se arrisca, se ela mesma se encontra amarrada ao "guia" com que deve transferir aos educandos os conteúdos tidos como "salvadores"?
\end{abstract}

É o que também defende PERRENOUD (2000; p.175). Para ele, “(...) quanto mais se caminha rumo a uma prática reflexiva, mais o ofício se torna uma profissão integral, simultaneamente autônoma e responsável”.

Outro aspecto importante levantado por SANCHO (2006) é o reconhecimento, por parte do professor que o principal objetivo de seu trabalho não é ensinar uma determinada disciplina, mas sim propiciar ao aluno a descoberta "das chaves do seu tempo", do sentido do mundo e também das realidades particulares em que estão inseridos, tornando-se cidadãos democráticos e participativos. Essa é a na verdade, 'a grande missão', que muitas vezes aparece embaçada por uma lógica produtiva de cumprir, a qualquer preço, os conteúdos programáticos.

A autora em referência salienta que os professores deverão estar capacitados para utilizar diferentes linguagens, códigos e instrumentos para acompanharem os novos tempos, e essa tarefa caberá àqueles que se propõe a formar professores. A formação deverá estar afinada com as 'novas' demandas, de forma que eles se tornem capazes de entender e dimensionar os problemas e as propostas da ciência, da cultura, da arte, da tecnologia e da política. Nas palavras de SANCHO (2006, p.22), eles precisarão ser "multialfabetizadores, isto é, (...) capazes de entender e de expressar-se em linguagem oral, escrita, visual, digital e gestual para poder ensinar a outros.” Ela expressa sua preocupação com a mudança na formação dos professores, em consonância com o que foi discutido com WESTPHAL (2000): a mudança deve ser tão ampla, quanto profunda e ainda alerta: o principal problema a ser enfrentado é a formação dos formadores de professores e daqueles que decidem os conteúdos e as condições em que se dará a formação dos mesmos. Esta parece ser uma preocupação atual do Governo Federal que 
acaba de apresentar uma proposta para a formação dos professores de ensino fundamental. Reconhecendo que as Universidades públicas precisam preparar mais e melhores professores e que essa tarefa de formação é bastante complexa, HADDAD (2008), o atual Ministro da Educação, explicou também que é preciso aproximar o currículo da realidade da escola, e que para isso a formação docente deverá ser aprimorada. Com a criação do Sistema Nacional de Formação do Magistério em Outubro de 2008, governos municipais, estaduais e as instituições de Ensino Superior deverão atuar de forma integrada. Caberá às Universidades Públicas assumirem a formação dos professores das escolas públicas, sob a coordenação da CAPES (Coordenadoria de Aperfeiçoamento de Pessoal de Nível Superior) que receberá cerca de 1 bilhão de Reais para esse fim. Embora as Universidades tenham tido, até hoje, completa autonomia para organizar seus cursos, segundo o Ministro, caberá a CAPES convencê-las de que mudanças terão que ser feitas no sentido de adequar esses cursos às reais necessidades das escolas.

Se esses recursos financeiros serão suficientes para a ousada meta de suplantar o fracasso escolar em nosso país e inseri-la no mesmo patamar dos países mais desenvolvidos, se haverá a adesão ampla e o comprometimento sério dos governos municipais e estaduais e a cooperação e o empenho das Universidades, são questões que deverão ser avaliadas e acompanhadas de perto pela sociedade, pois como salienta SAVIANI (2008), a educação é a questão crucial para o desenvolvimento nacional. Falar sobre isso parece "lugar comum" na sociedade e nos meios políticos principalmente, mas também para este autor, se a educação for o eixo do projeto de desenvolvimento nacional, sem ter que competir com as outras áreas prioritárias: saúde, segurança, desemprego, transporte, energia, meio ambiente, entre outras, ela estará apta para enfrentar todos esses problemas, superando o plano dos discursos e direcionando o máximo de recursos alocados para essa área:

Eis o grande desafio a ser enfrentado. É preciso acabar com a duplicidade pela qual, ao mesmo tempo em que se proclamam aos quatro ventos as virtudes da educação, as políticas predominantes se pautam pela redução de custos, cortando investimentos. Impõe-se ajustar as decisões políticas ao discurso imperante. Trata-se, pois, de eleger a educação como máxima prioridade, carregando para ela todos os recursos disponíveis. (p.3). 
Recuperar o prestígio e capacidade de ação dos profissionais de educação, através de salários compatíveis com o nível de responsabilidade que essa função lhes impõe, alta qualificação e possibilidade de fixá-los em uma única escola, atrairia muitos jovens para a profissão e motivaria os atuais educadores empenhar-se na tarefa de formar "cidadãos críticos, criativos, esclarecidos e tecnicamente competentes para ocupar os postos do mercado de trabalho de um país que viria a recuperar, a pleno vapor, sua capacidade produtiva" (SAVIANI, 2008; p.3).

\section{3 - De Alunos Protagonistas a Cidadãos Participativos - $O$ espaço a ser conquistado e as experiências já vivenciadas pelas escolas paulistanas: OP-Criança e as Conferências Infanto-Juvenis do Meio Ambiente}

O primeiro passo para o empoderamento ou empowerment de um indivíduo, está, sem dúvida, em ter o seu direito reconhecido ou na conquista dele para ocupar uma posição protagonista dentro de qualquer processo que envolva direta ou indiretamente, os elementos essenciais para tornar a sua vida mais digna e plena.

Para discutir a origem e os aspectos que permeiam o termo empowerment, serão aproveitadas as contribuições de MEIRA (2005). Para o referido autor, tanto o termo citado quanto outro comumente usado - ownership - foram cunhados por autores anglosaxões como Fien, Robotton, Sterling, entre outros, embasados na pedagogia crítica. O primeiro, empowerment, traduzido como empoderamento na America Latina, se refere a "assumir o poder" ou "à capacidade de exercer o poder sobre o que nos afeta"(p.271). O segundo, ownership, se refere à "apropriação" da realidade, seja ela simbólica ou material. De qualquer forma, os dois termos estão centrados na lógica de uma educação política e como lembra MEIRA (2005), tiveram especial adesão dos educadores latinoamericanos em virtude da forte influência da Educação Popular, nascida entre os anos 1960 e 1970, pelas mãos do educador Paulo Freire. Para o autor mencionado, quando se fala em "apropriação" remete-se à educação como plataforma e instrumento de conscientização cidadã defendida por Paulo Freire, da mesma forma que o termo "empoderamento", não quer dizer nada mais além do que a mobilização política, a que 
também se referia este educador brasileiro, considerando-se o sujeito emancipado como alguém que assume e compreende a sua realidade e tem a liberdade para transformá-la.

O empoderamento dos indivíduos para a transformação da realidade passa, portanto, pela possibilidade de participação consciente e ativa. MUNÕZ (2004, p.91 e 92) apresenta diversas definiçõos do termo 'participar' que ele foi acumulando ao longo do tempo, a partir de suas próprias experiências no âmbito pessoal e profissional, que serão aqui aproveitadas para melhor explicitar o que se espera de uma participação cidadã de crianças e adolescentes nos diferentes espaços de convivência dos mesmos:

- Participar é tomar partido em alguma coisa. É fazer parte de alguma coisa;

- Participar é organizar-se com outros para serem responsáveis conjuntamente pelo máximo de aspectos que constituem a nossa vida;

- Participar é sentir-se soberano;

- Participar é algo político, um jogo democrático;

- Participar não é uma finalidade, mas um meio que nos ajuda a tomar consciência da realidade;

- Participar é ser protagonista e solidário ao mesmo tempo, para mudar a partir do compartilhar;

- Participar é a capacidade de dar e de receber. Eu saio de mim, me expresso como sou e sou permeável;

- Participar é a capacidade de assumir dificuldades, incômodos e gozar a vida;

- Participar não é apenas decidir, mas trabalhar;

- Participar não é só falar, é também ouvir;

- Participar é acreditar que o projeto é importante.

Também o referido autor, partindo do princípio de que a participação cidadã significa compartilhar decisões que afetam a vida do indivíduo e da comunidade, defende que a escola precisa ser um espaço privilegiado onde os alunos possam realizar esse exercício cotidiano e de forma protagonista. É somente através da prática gradativa que se aprende o que é a participação democrática que se adquire a confiança e a capacidade para participar, já que nenhuma dessas coisas pode ser ensinada de forma abstrata, como afirma Hart, citado por MUÑOZ (2004; p.9). Sobre isso, SANCHO (2006, p.22) observa que "fala-se da autonomia, de criatividade e de participação, mas fortalece-se a burocracia e as decisões hierárquicas".

MORIN (2002) indaga-se sobre a democracia na escola, ao mesmo tempo em que lança esse questionamento à sociedade: por que a escola não pode ser na prática e concretamente um laboratório de vida democrática? Ele enfatiza que os alunos deveriam aprender na sala de aula como se comportar diante de um debate, argumentando, 
conhecendo e vivenciando as regras necessárias à condução de uma discussão, conscientizando-se da necessidade de ouvir, de respeitar e de compreender o pensamento do outro, sobretudo das minorias e marginalizados. A escola deveria ensinar que o principal requisito para aprender a democracia na prática deveria ser o aprendizado da compreensão.

(...) a sala de aula deve ser um local de aprendizagem do debate argumentado das regras necessárias à discussão, da tomada de consciência das necessidades e dos procedimentos de compreensão do pensamento do outro, da escuta e do respeito às vozes minoritárias e marginalizadas. Por isso a aprendizagem da compreensão deve desempenhar um papel capital no aprendizado democrático (MORIN, 2002; p.112).

Todavia, voltando nossa atenção para a realidade específica da escola pública no Brasil hoje, logo se percebe que ela está longe de ser ideal. Como bem designa PARO (2002), são tantos os problemas que a assolam que se poderia dizer que ela vive uma situação de calamidade. Apesar disso, o autor ressalta que o objetivo político da escola, mesmo nesse cenário de degradação do ensino e das condições de trabalho dos educadores, deveria ser o de socializar a cultura e ao mesmo tempo, ainda que em pequena proporção, dentro de suas possibilidades, contribuir para democratização da sociedade. Esta seria, segundo o autor, sua função social.

O respeito à pluralidade de idéias, de jeitos de ser e de viver, das necessidades e do direito dos outros requer o aprendizado da compreensão e vai, além disso, como lembra GADOTTI (2000), pois a democracia na escola também será insuficiente se não for ensinada a solidariedade, valor oposto à competitividade. Portanto, a participação democrática, como currículo-em-ação na escola, não pode estar dissociada da compreensão e da solidariedade, isto é, da pretensão de construir uma sociedade diferente da que se tem hoje e verdadeiramente democrática. Entretanto, se a sociedade que temos, não é a que sonhamos, também a escola não é a que queremos, pois muitas vezes acaba reproduzindo os parâmetros sobre os quais os poderes dominantes na sociedade julgam e tratam a infância e a adolescência. Na análise de MUÑOZ (2004), seriam aqueles que "ainda não": que ainda não sabem, que ainda não podem, porque ainda não são adultos e, portanto, essa sociedade não deseja sua participação e se 
organiza para impedir que ela aconteça, colocando-os numa espécie de sala de espera: a sala de espera dos "ainda-não".

CESAR (2000), em seu trabalho sobre a genealogia da adolescência lembra as razões históricas para essa visão construída sobre o adolescente, em que ele aparece como "um problema" a ser decifrado e resolvido pela ciência médica e mais tarde pela psicologia e pedagogia influenciadas por ela. Essa visão, segundo a autora, que também utiliza o pensamento de Foucault como referência, perdura até hoje nas instituições de ensino justificando diversas práticas sociais, tais como: a psicologização da educação, a segregação do fracassado, a punição dos indisciplinados, a necessária ocupação e vigilância do ocioso, a retirada da voz da rebeldia, o não investimento em políticas de atenção ao jovem, a desconsideração de sonhos e realidade de uma pessoa que ainda não é considerada como gente, entre outras. A escola, nesse sentido, não está aberta para fazer aflorar idéias na cabeça dos adolescentes, mas ao contrário, para "fazer a sua cabeça", disciplinando-o, tornando-o "normal".

Em um encontro com Coordenadores Pedagógicos da Rede Municipal de Ensino de São Paulo, em 2004, sobre protagonismo infanto-juvenil, MUÑOZ (2004) analisou a seguinte declaração de uma aluna:

\footnotetext{
Eu acho muito estranho vocês falarem sobre o que nós adolescentes queremos e decidir o que seria bom pra gente. Nunca ninguém pergunta pra gente o que queremos ou do que nós gostamos. Nesses encontros que são pra falar da gente nunca somos convidados para ajudar a decidir ou, pelo menos falar, o que realmente nos interessa... (SÃO PAULO, 2004; p.32).
}

Para Muñoz (SÃO PAULO, 2004; p.32) os adultos mesmo quando pensam ou discutem sobre o protagonismo infanto-juvenil, o fazem sem se deslocarem do mundo onde vivem - o mundo de adultos, com idéias e valores de adultos e nem sequer se dão conta da presença concreta e da voz dos mais interessados: a criança, o adolescente, o jovem.

Trata-se de uma armadilha calculadamente criada para manter o poder daqueles que vivem à custa da dominação de uma maioria pouco esclarecida e da qual a escola, apesar de sua frágil autonomia, precisa escapar, concentrando todos os seus esforços 
para desarmá-la dentro e fora do seu espaço. Isso só se dará por meio de uma comunidade escolar alerta, capaz de acreditar e lutar pela democratização do conhecimento e das relações entre os sujeitos do processo educativo. A postura crítica e o trabalho intencionalmente revolucionário dos educadores potencializarão o desejo de mudança e de ação dos seus educandos e incentivará a criatividade desses meninos e meninas no dia-a-dia da escola, proporcionando o empowerment dos mesmos. Desta forma, como pensa MUÑOZ (2004), um outro modelo de sociedade, democrática de fato, inclusiva, com uma cidadania global, se tornaria real, onde o "tudo para a criança, mas sem a criança" ou o "tudo para o povo, mas sem o povo" (p.36), já não terá razão de existir.

Pode-se dizer que essa é uma mudança que deverá passar urgentemente pela escola, mesmo não sendo ela quem modela a sociedade, mas o inverso, de acordo com as forças que detêm o poder, como pensa FREIRE (1986). É o que também defende PARO (2002, p.10): "Se queremos uma escola transformadora, precisamos transformar a escola que temos aî" e isso implica em reformular o sistema de autoridade que foi imposto de forma astuta pelo Estado, atribuindo um pretenso poder ao diretor da escola, mas obrigando-o a ser um mero executor de leis e normas ditadas pelo próprio Estado. Um poder engessado que não permite a autonomia para vôos mais altos dentro do projeto de gestão da escola e que também interfere no projeto pedagógico. Significa democratizar as relações na escola, que só é possível com a participação de toda a comunidade escolar nas decisões e é claro que isso inclui crianças e adolescentes. Nesse aspecto, ANTUNES...et al (2004) lembra que para que a criança seja valorizada no sentido de ter garantido o seu direito à voz e à ação, é preciso prepará-la, mas também se faz necessário educar os adultos com os quais ela convive, pois para que ela viva o seu protagonismo, devem os educadores também fazê-lo e isso exige uma nova educação. Exige também, uma nova ordem de poder no interior da escola, na comunidade, na cidade e assim sucessivamente, de maneira que o autoritarismo seja derrotado pela concretização da democracia e da cidadania plenamente vivida. As palavras de ANTUNES...et al (2004) reiteram o que já foi discutido até aqui com outros autores sobre a importância de se formar alunos autônomos e participativos dentro e fora da escola: 
Educar pressupõe tempo. Tempo para construir hábitos, valores, compromissos. Se esperamos que as crianças, adolescentes e jovens amem a cidade, cuidem do lugar em que vivem, participem de sua organização, precisamos envolvê-las, incluí-las no processo de decisão da organização dos espaços que ocupam. Elas precisam aprender a criticar, a propor, a se comprometer, a avaliar, a replanejar. Entendemos que é assim que podemos contribuir para formar novos cidadãos e cidadãs e qualificar o exercício da cidadania, viabilizando, assim, um outro mundo possível. (p.29).

Para alcançar esse objetivo, assim como é defendido pela autora, só o discurso não basta - é preciso ultrapassar a teoria e alcançar a prática, que só se realiza de fato, quando há o desejo e a disposição de fazê-lo, não apenas pelas escolas, mas também por governos comprometidos e, portanto, recurso orçamentário destinado para isso.

ANTUNES...et al (2004) é organizadora de um livro intitulado "Orçamento Participativo Criança - Exercendo a cidadania desde a infância”, no qual são descritas as experiências vividas por milhares de crianças e adolescentes da Rede Municipal de Ensino de São Paulo nos anos de 2003 e 2004. Esse processo foi desenvolvido a partir da articulação entre a política de gestão da Cidade de São Paulo, com a política educacional e mais tarde, também com o Programa do MEC/MMA, denominado "Vamos cuidar do Brasil com as escolas", culminando nas Conferências Infanto-Juvenis do Meio Ambiente em 2003, 2005 e 2008. Essas iniciativas serão descritas preferencialmente nessa pesquisa por estarem envolvendo diretamente a democracia participativa, a educação ambiental e o empowerment dos alunos de ensino fundamental das escolas municipais de São Paulo, objeto do presente estudo.

- O Orçamento Participativo-Criança (OP-Criança) e o Orçamento ParticipativoCidade (OP-Cidade):

Anteriormente ao nascimento do OP-Criança, a população de São Paulo já vivenciava o OP-Cidade, que segundo PONTUAL (2000), foi implantado pela Prefeitura (2001-2004), como um instrumento a ser utilizado para combater a exclusão social, lembrando também o seu forte caráter educativo por permitir o exercício da cidadania ativa oposta à tradição de tutela e práticas clientelistas presentes em nossa história. Segundo o autor, todos ganham, inclusive o governo que aprende a lidar com as diferentes necessidades e interesses dos distintos segmentos da comunidade, desenvolvendo ou melhorando atitudes democráticas. SÁNCHEZ (2004) chama a 
atenção para o fato de que a ONU em 1996, considerou esse mecanismo democrático como uma prática positiva de gestão e explicita o formato e o mecanismo do OP Paulista:

\begin{abstract}
É um processo de democracia direta, voluntária e universal, onde a população pode discutir e decidir sobre o orçamento público e o investimento em políticas públicas. $O$ orçamento público e o investimento em políticas públicas. $O$ orçamento participativo - OP combina democracia direta com a democracia representativa, uma das maiores conquistas da humanidade, que deve ser preservada e qualificada. A participação da população se efetiva de maneira livre e universal nas assembléias públicas do OP. Todo cidadão ou cidadã, independente de sua organização partidária, associativa e credo religioso tem assegurada sua participação no processo e haverá eleições livres de delegados e delegadas regionais $e$ de conselheiros $e$ conselheiras para o Conselho do OP... O processo do OP deve ter regulamento, critérios distributivos e metodologia de planejamento. Esta regulamentação deve ser elaborada pela comunidade par ser firmado um contrato social entre governo e a sociedade.(p.456)
\end{abstract}

O referido autor argumenta que o OP proporcionou o nascimento de uma cultura política cidadã, pública e democrática e ressalta o seu “(...) grande potencial para recriar laços de solidariedade e vínculos de pertencimento a uma vida associativa de inspiração cívica e democrática (p.456)”.

ANTUNES...et al (2004), salienta que o Orçamento Participativo Criança (OPCriança) de São Paulo, nasceu a partir da ótica de que "um outro mundo é possível" pressuposto do Fórum Social Mundial. Um mundo onde as crianças e adolescentes poderão optar pelas políticas governamentais que afetam suas vidas, abrindo espaço para o surgimento de uma sociedade mais justa e mais democrática, onde elas também não serão invisíveis. "Educar para e pela democracia pressupõe criar condições para que o cidadão e a cidadã se construam no cotidiano da escola e da cidade, nas pequenas ações do dia-a-dia" (p.29). Por isso é preciso cuidar dos discursos e das práticas cotidianas dos espaços educacionais para que as crianças tenham a chance de se tornarem cidadãos numa cidade que também seja democrática e educadora e nesse sentido, a autora alerta para o fato de que de nada valerá o conhecimento se não for para formar pessoas solidárias, propensas ao diálogo, à cooperação e à convivência social que construa uma vida mais digna e sustentável para todos. Conforme ela afirma, é na escola que muitas crianças entram em contato pela primeira vez com a sociedade e a 
grande oportunidade de edificar a sua autonomia está na participação. O convívio democrático com os outros lhes ensinará o significado do 'coletivo', do respeito pelo espaço público e de como se co-responsabilizar por ele. Para a autora acima citada (p.27), o OP-Criança em nada se parece com políticas públicas marcadas por "ações isoladas, fragmentadas, descontínuas, imediatistas, ao sabor das urgências". Não se trabalharia nas escolas, portanto, com um calendário de datas especiais em que se pretende valorizar a cidadania de forma pontual, como "o dia da cidadania, o dia da família na escola, o dia da criança...e, no resto do ano, a criança é desrespeitada no seu direito de falar e decidir". Ainda acerca do valor desse projeto, ANTUNES ...et al (2004) acrescenta que:

O OP-Criança aceita o desafio de fazê-los entender o conflito como inerente à convivência e como elemento importante para o nosso processo de humanização. Oferecer oportunidades de aprender a decidir coletivamente, a vivenciar e experimentar a validade do diálogo crítico como mediador dos conflitos, a construir, em grupo, acordos provisórios ou mais duradouros, a impacientar-se diante da divergência ou discordância, mas manifestar-se com respeito e justiça, a definir prioridades diante de tantas escolhas... (p.30).

Também GADOTTI (2000) sai em defesa desse projeto que segundo ele, desconstrói a lógica do consumismo e mercantilização na educação das crianças e adolescentes, resgata o que há de mais importante na essência do ser humano: o sujeito e a solidariedade, permitindo à criança sonhar, elaborar projetos e viabilizá-los, tanto no nível individual, como no coletivo. É no processo de negociação constante, que ela vai aprender a se solidarizar, a compreender o sentido do bem comum e a superar o individualismo e o autoritarismo presentes na escola, na comunidade, na cidade, rumo à ‘cidadania planetária' já citada pelo referido autor.

O OP-Criança teve inicio em 2003 envolvendo, experimentalmente, apenas alunos do ensino fundamental de quatro Centros Educacionais Unificados (CEUS): Aricanduva, Rosa da China, Jambeiro e Perus. Em 2004, expandiu-se para todas as Escolas de Ensino Fundamental da Rede Municipal, totalizando 477 U.E.s e abrangendo alunos entre 7 e 14 anos de idade. Para implementar esse projeto na Rede, professores, funcionários, equipe técnica (Direção, Assistentes de Direção e Coordenação Pedagógica), além dos alunos, tiveram a oportunidade de participar de cursos de 
formação e encontros preparatórios organizados pelo Instituto Paulo Freire, parceiros da Secretaria Municipal de Educação nesse projeto, além da Coordenadoria do Orçamento Participativo, responsável pelo OP-Cidade. A metodologia desse projeto pressupunha a constituição de dois grupos: o Grupo Motor, formado por adultos com a função de criar condições para a realização das ações das crianças nas escolas e o Grupo Faísca, formado por crianças, adolescentes e jovens, que tinha como função, envolver, explicar e sensibilizar as crianças para que se comprometessem com o OP-Criança (ANTUNES 2004, p.40).

Segundo a referida autora, O Grupo Motor do qual faziam parte professores do ensino fundamental I e II, da educação infantil, além de Diretores e Assistentes de Direção das Escolas, Coordenadores Pedagógicos, Supervisores Escolares, Auxiliares Técnicos de Educação I e II, Diretor de Equipamento Social, Coordenadores das Coordenadorias de Educação, Professores prestadores de serviços técnicos educacionais nas Coordenadorias de Educação, Secretários de Escola, Assessores Técnicos e representantes da comunidade, como membros dos Conselhos de Escola e delegados do Orçamento Participativo de São Paulo, participaram de um curso de 70 horas, com dias e horários diversos em cinco Pólos diferentes da Cidade. Os conteúdos visavam preparar os participantes para desenvolverem as etapas do OP-Criança, por isso, abordavam, segundo ANTUNES (2004; p.41-42):

- A metodologia para a constituição dos Grupos-Faísca nas U.E.s;

- $\quad$ Leitura de Mundo;

- Orçamento Público, Orçamento Participativo, Orçamento Participativo Criança;

- Regimento do OP-Criança;

- Democracia Representativa e Democracia Direta;

Assembléias para escolha dos delegados e das prioridades (por classe; ano/ciclo; ciclo; interciclos): como organizá-las, como realizá-las, material necessário para cada instância de votação (cédula de votação de delegado, cédula de votação da prioridade para a educação, ata das assembléias, etc.), papel dos delegados, dos Conselheiros, do Grupo Motor, do Grupo Faísca;

- Assembléias nas escolas;

- Plenárias nas Coordenadorias;

- Registros do processo nas Assembléias (sistematização dos dados) e...

- Como organizar a devolutivalavaliação ("Fala Escola") e Mostra e Registro de Memória: 'Lições do OP-Criança'.

Ainda de acordo com a autora supracitada, a formação dos Grupos-Faísca previa até duas horas de encontros semanais e o educador do Instituto Paulo Freire 
disponibilizava até 4 horas semanais para acompanhamento das crianças e dos outros segmentos envolvidos da comunidade escolar. A metodologia privilegiava a construção do processo "desde/com", segundo os pressupostos de Cesar Muñoz, colaborador do projeto. Trata-se de trabalhar "a partir da" infância, adolescência e juventude, "com" o apoio dos adultos, e não "fazer por" ou "para", numa atitude paternalista. Como ANTUNES (2004, p.44) relembra, "essa metodologia pressupõe um 'adulto de passagem ligeira', que não se sobrepõe à criança".

- As Conferências Nacionais Infanto-Juvenis do Meio Ambiente:

Também em 2003, o Ministério de Educação e Cultura (MEC) através da Coordenação Geral de Educação Ambiental (CGEA), em parceria com o Ministério do Meio Ambiente (MMA), lançou a I Conferência Nacional Infanto-Juvenil do Meio Ambiente.

Para BRASIL (2006), essa Conferência significou um grande avanço no sentido de mobilizar e organizar jovens em torno da questão socioambiental. Esse evento reuniu delegações de adolescentes entre onze e quinze anos de idade de todos os estados do Brasil e Distrito Federal, oriundos do ensino fundamental, bem como jovens de dezesseis a vinte e nove anos atuantes nos Conselhos Jovens das Comissões Organizadoras Estaduais. Segundo BERNARDO...et al (2006), houve a participação direta de 16 mil escolas, num total de seis milhões de pessoas, entre professores, comunidades e jovens, a maioria deles do ensino fundamental. Foram escolhidos delegados e delegadas pelos próprios adolescentes em suas escolas e também se contou com a participação especial de jovens observadores internacionais. Além disso, essa versão infanto-juvenil da Conferência que ocorreu paralelamente à Conferência Nacional do Meio Ambiente em Novembro de 2003 em Brasília, foi considerada um meio inovador de se implantar políticas públicas de educação ambiental no ensino formal.

Os cinco temas que orientaram essa primeira Conferência foram: Nossa água, Seres vivos, Nossos alimentos, Nossa escola e Nossa comunidade. As escolas de Ensino Fundamental em todo o território nacional foram orientadas a discutir, com toda a comunidade escolar os referidos temas e elaborar propostas para melhorar o meio 
ambiente na comunidade local através de um processo que culminaria em uma PréConferência na escola. Os alunos elegeriam um delegado e um suplente por escola, e também um cartaz contendo a melhor proposta sobre como cuidar do Brasil. Os nomes dos delegados e seus suplentes, bem como o cartaz vencedor seriam enviados para Brasília. As propostas formariam um documento que posteriormente seria publicado pelo MMA/MEC, servindo de base para as discussões na Conferência Nacional.

Na Cidade de São Paulo, a apresentação dos delegados eleitos para disputarem a eleição a nível estadual foi feita durante a Conferência Municipal do Meio Ambiente, onde houve um espaço especial para que os alunos da Rede apresentassem os resultados das Pré-Conferências ocorridas em suas U.E.s.

Em 2004, num segundo momento do OP-Criança, procurou-se articular a experiência vivenciada com o currículo da escola a partir de temas geradores, que se distribuíram de Agosto a Novembro: Protagonismo Infanto-Juvenil: saberes, valores e práticas (agosto), Protagonismo Infanto-Juvenil: espaços e expressões (setembro), Protagonismo Infanto-Juvenil: Escola Cidadã e Cidade Educadora (outubro), Protagonismo Infanto-Juvenil: Ecopedagogia e Agenda 21 (novembro). Assim, em Novembro de 2004, os educadores da Rede Municipal de São Paulo, juntamente com os alunos eleitos delegados do OP-Criança e também da Primeira Conferência Infanto Juvenil em suas escolas, foram convidados a participar de um curso com os seguintes objetivos:

- Fortalecer espaços de discussão ambiental já existentes e ampliar as discussões com os conceitos da Ecopedagogia;

- Discutir os temas da Ecopedagogia na perspectiva da construção da Escola Cidadã e da Cidade Educadora, relacionando-os às propostas do OP-Criança e adequando-as à realidade local e à participação da comunidade;

- Inserir a Agenda 21 através da formação da COM-VIDA (oficina de futuro) junto às crianças, criando comissões locais que discutam a questão ambiental permanentemente e introduzindo essa ação como motivadora do Grupo Faísca na continuidade de seus encontros na escola. 
- Proporcionar vivências coletivas que provoquem discussões em torno dos problemas ambientais, da sustentabilidade e da formação da Agenda 21 através de formas lúdicas, apoiadas nos fundamentos da proposta Ecopedagógica.

Esse processo colaboraria também para a preparação da II Conferência InfantoJuvenil do Meio Ambiente nas escolas em 2005, subsidiando as U.E.s para a implantação as COM-VIDAs - Comissões de Meio Ambiente e Qualidade de Vida nas Escolas, envolvendo educadores, alunos e comunidade na construção da Agenda 21 Escolar que não se restringisse apenas ao espaço escolar (apesar do seu nome), mas que buscasse melhorar a qualidade de vida também do seu entorno, no bairro e no município. Ao mesmo tempo, os CJs - Coletivos Jovens de Meio Ambiente, envolvendo jovens de quinze a vinte e nove anos, deveriam construir ações e projetos socioambientais transformadores. Tanto as COM-VIDAs, quanto os CJs, fazem parte de um programa do MEC/MMA denominado "Vamos Cuidar do Brasil com as Escolas".

A II Conferência Nacional Infanto-Juvenil do Meio Ambiente ocorreu no ano seguinte (2006), desta vez com novos temas escolhidos a partir de questões mundiais presentes em acordos, tratados e convenções internacionais assinados pelo Brasil, tais como: Mudanças Climáticas, Biodiversidade, Segurança Alimentar e Diversidade Étnico Racial. O processo de organização seguiu a mesma lógica da primeira Conferência e novamente foram eleitos delegados (as), entre 11 e 14 anos e as propostas de escolas de ensino fundamental que aceitaram o convite de dar prosseguimento a esse trabalho iniciado na I Conferência. A Conferência na Escola, segundo BRASIL (2007), é um momento muito rico para a comunidade escolar (estudantes de todos os turnos, professores, professoras, funcionários e a comunidade) e inclusive para as comunidades indígenas, quilombolas, assentamentos rurais e meninos e meninas em situação de rua, convidados também a realizar e participar das Conferências. Essa ação permite conhecer, debater e tomar atitudes para garantir um Planeta mais sustentável, eqüitativo e justo. É uma importante contribuição para mudar nosso lugar, nosso país e também o mundo.

Um documento intitulado "Carta das Responsabilidades - Vamos Cuidar do Brasil”, elaborado pelos delegados e delegadas nas oficinas realizadas durante a 
Conferência, foi posteriormente entregue ao Presidente da República. O conteúdo desse documento foi traduzido para a linguagem do rádio, publicidade, hip-hop e jornal, de tal forma que se transformou também em produto de educomunicação dessas crianças e adolescentes. A Carta na versão infanto-juvenil elenca os principais compromissos das crianças e adolescentes com o meio ambiente e foi inspirada na Carta das Responsabilidades Humanas, um documento proposto pela Rede lnternacional Aliança para um mundo Responsável, Plural e Solidário. O objetivo é sensibilizar as pessoas a compartilharem as responsabilidades, mobilizando todo país para os grandes desafios socioambientais. As duas primeiras Conferências reuniram cerca de 8 milhões de pessoas e contaram com a participação de 26 mil escolas. Nesse processo houve a formação de 25 mil professores e 21 mil alunos em 2004 e 2005, com o Programa de Formação Continuada de Professores e Estudantes em Educação Ambiental promovido pelo Ministério da Educação / Secad - Secretaria de Educação Continuada, Alfabetização e Diversidade, Departamento de Educação para Diversidade / Coordenação-Geral de Educação Ambiental - CGEA. (BRASIL 2007).

A III Conferência Nacional Infanto-juvenil pelo Meio Ambiente (CNIJMA) ocorreu em novembro de 2008 e segundo dados do Ministério de Meio Ambiente (BRASIL 2007), o tema geral escolhido foi: "Mudanças ambientais globais", cujos subtemas abordados também nas conferências estaduais, escolas e comunidades foram: Clima, Água, Biodiversidade, Produção e consumo e Energia.

- $\underline{\text { Outros projetos: }}$

Especificamente na Rede Municipal de Ensino de São Paulo, a partir de 2001, duas outras iniciativas colaboraram para fortalecer o protagonismo dos alunos nas escolas, tornando-se valiosos instrumentos pedagógicos para viabilização do OPCriança e das Conferências Infanto-Juvenis do Meio Ambiente. Além disso, contribuíram para transformar o educando em sujeito de sua própria aprendizagem. Estas iniciativas foram: o projeto EDUCOM.Rádio e os Grêmios Estudantis. No primeiro caso (EDUCOM.Rádio), na visão de SÃO PAULO (2003, p.10), o projeto: de aprendizado, sugerindo que se tornem menos burocráticas e mais dinâmicas (...) valorizando o que é essencial: a formação de indivíduos apontando para um caminho de possibilidades onde o autoconhecimento, o desenvolvimento 
do potencial humano e a orientação para a vida são resultados esperados.

Pais, alunos, professores e funcionários das U.E.s participaram do processo de capacitação para desenvolver o Projeto EDUCOM.Rádio, que buscava, através da linguagem radiofônica, formar educomunicadores, profissionais da Cultura e Educação que trabalhassem “ (...) na convergência entre essas duas ciências agregando competências comunicativas à sua ação educativa e provocando uma dinâmica multicultural, que vá além da aquisição de conhecimentos escolares" (SÃO PAULO (2003, p.10). O curso foi promovido pela Secretaria Municipal de Educação (SME), em parceria com a Escola de Comunicação e Arte (ECA) da USP e foi oferecido de forma descentralizada, ocorrendo em diferentes pólos para atender às diferentes regiões da Cidade. Ele ocorreu, aos sábados,em período integral durante os dois anos a partir de sua criação e apesar da qualidade atestada pelos participantes, o projeto apresentou posteriormente alguns pontos fracos, como: a saída das U.E.s das pessoas capacitadas para lidar com o equipamento (a Rádio) e a dificuldade de manutenção e reposição de peças e equipamentos, o que acabou limitando a sua utilização na Rede em algumas escolas nos anos subseqüentes à sua implantação, problemas estes que persistiram, inclusive, na gestão seguinte. Apesar disso, foram inúmeros os trabalhos realizados na Rede, utilizando essa ferramenta inovadora e dinamizadora.

No segundo caso, houve um investimento no fortalecimento dos colegiados internos das U.E.s, como o Grêmio Estudantil, por exemplo, além dos Conselhos de Escola, órgão que também conta com a participação de alunos entre outros integrantes da comunidade educativa. Os grêmios participaram de encontros nas Coordenadorias de Educação e também nas Subprefeituras, onde foram inseridos nas discussões regionais para a elaboração de políticas públicas para a juventude. Não houve, porém, investimento na continuidade desse movimento a partir de 2005.

\subsection{1 - A Comunidade Educativa: Do Direito da Criança à Opção de Educadores e Pais por essa Concepção de Educação}

A participação traz reflexos positivos para escola. Quando há a democratização do poder, melhora a qualidade de ensino, abre-se caminho para uma conscientização dos indivíduos quanto ao seu papel e também do Estado, dentro e fora do espaço escolar 
(GADOTTI \& ROMÃO, 2001). Democratizar os espaços escolares significa "retomar a construção crítica de uma cidadania cada vez mais participativa, com cidadãos comprometidos com suas comunidades, é ação que se deve fazer no chão da Unidade Educacional" (SÃO PAULO, 2004; p.28). Para isso, é preciso que os educadores (professores, diretores, coordenadores, vigias, agentes escolares, famílias, entre outros), aceitem o compromisso de “(...) construir permanentemente a participação crítica e ativa de todos os segmentos envolvidos com suas práticas educacionais (p. 28-29)". Quanto aos alunos, estes têm o direito garantido de terem "liberdade de opinião e expressão" (art.15 e 16) no Estatuto da Criança e do Adolescente (Lei 8.069/90), bem como na própria Constituição Federal (Art.5 $5^{\circ}$ IX), (...) onde se recomenda que a criança e o jovem sejam constantemente estimulados a exercer esse direito, sem limites, considerando-se a liberdade de expressão como um elemento primordial na formação da personalidade (GADOTTI \& ROMÃO, 2001).

Os autores em referência salientam que a gestão democrática é inerente ao ato pedagógico e se contrapõe a uma concepção de educação centralizadora e autoritária. GADOTTI \& ROMÃO (2001, p.17) se apóiam nas visões de Janusz Korczak, para quem "o primeiro e indiscutível direito da criança é aquele que lhe permite expressar livremente suas idéias" e de Dallari, que lembra que "toda criança é um ser dotado de inteligência, que pensa e deve ter o direito de pensar com sua própria cabeça", esses autores, reafirmam que o aluno precisa participar das decisões que afetam sua vida dentro do projeto pedagógico da escola.

O educador só conseguirá radicalizar sua prática em direção a esse projeto novo de escola e sociedade se estiver disposto a correr riscos, optando pela resistência a tudo que se contrapõe a esse movimento, ainda que não saiba com quem e com quantos vai poder contar e que espécie de punição poderá vir a sofrer. E educadores como estes são reais e é possível encontrá-los espalhados nas Redes de Ensino e em diferentes cantos deste País. SANTOS NETO (2004) quando discute sobre a construção da identidade do educador, salienta que a eleição consciente e clara de um projeto de vida e de educação por parte dos mesmos, pode contribuir para anular os efeitos da ideologia dominante que procura homogeneizar os processos de construção da identidade dos indivíduos. Esta seria uma forma eficaz da qual os educadores se valeriam para combater e resistir à 
negação da esperança que está inserida nessa ideologia e conseqüentemente à desumanização do mundo.

Mesmo falando sobre um cenário político do século passado, FREIRE (1986, p.49) desvenda muito bem essa missão e seus desafios, quando se tem no poder a classe hegemônica que se recusa a partilhá-lo com os "dominados". O referido autor afirma que "seria ingênuo demais pedir à classe dirigente do poder que pusesse em prática um tipo de educação que pode atuar contra ela", por isso a necessidade de fiscalização política sobre a educação. Assim, ele parece instar educadores e a parte da sociedade dominada e excluída a assumir essa responsabilidade de fazê-lo à revelia desse tipo de poder constituído. Esse deve ser o sonho político do professor libertador: “(...) reinventar a sociedade, ocupar o espaço das escolas, o espaço institucional, para desvendar a realidade que está sendo ocultada pela ideologia dominante, pelo currículo dominante!" (p.49). Esse professor deve estar consciente da enorme contradição que vive a educação, de não ser a alavanca transformadora, justamente porque deveria sê-lo (FREIRE, 1986).

Também GADOTTI \& ROMÃO (2001, p.26), ao analisarem o processo histórico da participação popular nos processos decisórios no Brasil, avaliam que a dificuldade dessa participação da população tem se dado (...) "não pelo seu absenteísmo, ataraxia ou apatia em relação aos negócios públicos, mas de obstáculos construídos e colocados à sua frente pelos que querem ter o monopólio da decisão" e que a escola, um dos capilares do Estado, não está livre desse "processo sonegador da auto-afirmação pessoal da participação nas decisões coletivas (...)".

SANTOMÉ (2001) exemplifica isso, ao discorrer sobre a tentativa de cooperação das famílias na ação educativa de seus filhos na escola. Para ele, esse segmento da comunidade educativa não encontra condições propícias para desempenhar seu papel como deveria, por uma série de motivos. Entre esses motivos, estaria a dificuldade de comunicação e de colaboração no trabalho dentro dessas instituições, em função do predomínio de um modelo conservador de administração escolar e que permeia também o trabalho pedagógico. Nesse modelo, o professor e o aluno devem ficar isolados no processo de ensino-aprendizagem, sem sofrer a interferência "não especializada" de outras pessoas, como os pais, muitas vezes. 
Muito embora SANTOMÉ (2002) esteja se referindo a um cenário escolar espanhol das últimas décadas, ele é perfeitamente comparável com o cenário brasileiro, pois também aqui vivemos um modelo de democracia capitalista, ou seja, onde os reflexos do enfraquecimento das concepções esquerdistas no mundo serviram para fortalecer os discursos profissionalistas, cuja retórica era de que "quem não sabe, não fala, apenas obedece quem sabe". Assim, sob a influência desse modelo, a escola não desenvolvia estratégias para facilitar informações às famílias e incentivar sua participação. Seus saberes eram desconsiderados e era dado a elas apenas o direito de “(...) repensar práticas e rotinas características de modelos pedagógicos tradicionais e autoritários" (p.40). Como os pais, freqüentemente, também foram formados por esses modelos, não aceitavam com facilidade outros mais progressistas quando eram defrontados com estes, através das práticas de alguns professores. A falta de informações os fazia optar por aquilo que já conheciam e inclusive vivenciaram e que não iriam renegar, a menos que fossem realmente convencidos de sua eficácia (SANTOMÉ, 2001) e quando esse convencimento acontece, educadores e pais se tornam aliados no processo educativo que interessa a todos, e conseguiram abrir, mais facilmente, caminhos para a emancipação da escola no sentido de democratizar suas relações e inovar as suas práticas.

A escola, por sua vez, mesmo não gozando de uma verdadeira autonomia, por ser fiscalizada pelo Estado, é capaz de encontrar "pequenos espaços de liberdade" através dos quais pode revelar-se e produzir democraticamente, outros currículos e outras relações de poder. Ideal seria que se inspirasse nos movimentos sociais que, como lembra FREIRE (1986), apesar de manterem uma distância maior do controle oficial e, portanto, respirarem uma atmosfera de maior autonomia do que as escolas, conseguem atuar pelas mudanças sociais e pela educação crítica. A conjugação dos interesses e a concomitância da militância nesses dois espaços de educação seria, portanto, a opção mais acertada para um professor que deseja ser emancipador, como também defende FREIRE (1986).

Levando em consideração o que diz SANTOMÉ (2001) sobre a militância social de professores e professoras, estudos comprovam esse potencial nos referidos profissionais, além da existência de uma "certa autonomia" nas instituições escolares 
que permite uma ação contra a corrente da dominação vigente na sociedade como afirma Torres, citado por SANTOMÉ (2001; p.34). O autor alerta, porém para as simplificações que podem gerar a ilusão de que as concepções e práticas dos professores são homogêneas, tais como "que o professorado é politicamente de esquerda, progressista em suas concepções e ideologias sociais; que sempre tem claro que vive em uma sociedade onde as injustiças sociais são visíveis e determinadas pelos sistemas de organização e governos injustos". Portanto, se há professores com visões de mundo e atuações sociais diferenciadas, não se pode imaginar que essas concepções se harmonizem e não disputem espaço no campo ideológico e cultural, no momento em que esses professores se juntam para construir e colocar em prática o currículo da escola. O importante é que se garanta na escola que os valores essenciais, como o respeito, a solidariedade, a ética, a tolerância, entre outros, sejam cultivados e estejam visíveis na ação docente de cada um deles.

Quando se fala de concepções dos professores, é preciso ter em mente, que estes não se encontram numa posição estática dentro de um grupo social ou classe, comprometidos indeterminadamente com as ideologias e ações próprias desse grupo ao qual pertencem ou militam, pois assim como qualquer ser humano, suas identidades e convicções são construídas a partir das circunstâncias ou experiências vividas ao longo de todas as suas vidas. SANTOMÉ (2001, p.36) baseia-se na pesquisa de SULTANA (1991) realizada na Nova Zelândia no início da década de 1990 para falar da mudança de postura que pode ocorrer com os professores: "a conscientização e as atividades políticas do professorado tenderão cada vez mais em direção às agendas progressistas antes que conservadoras caso se engajem em movimentos sociais democráticos externos à instituição escolar que afetem as suas percepções e compromissos, tanto individual quanto coletivamente".

É interessante considerar a constatação feita por esse pesquisador, pois isto abre uma importante perspectiva para se pensar num movimento de formação política dos professores onde essa conscientização gere estímulo para aqueles que se dispuserem a agir politicamente dentro um espaço que é eminentemente político - a escola e revolucionar a estrutura conservadora à qual, muitas vezes, esta instituição e grande parte de seus agentes, encontram-se atrelados. 
Na análise de SANTOMÉ (2001), professores que exercitam sua cidadania, lutando por democracia e melhores condições de vida para os excluídos da sociedade, seja em seu próprio bairro ou em outras esferas sociais mais amplas das quais ele faz parte, certamente despertarão para o fato de que as instituições de ensino são também espaços de luta e tentarão derrubar as incoerências que se instalam nesses lugares, onde o individualismo ou o imobilismo muitas vezes imperam.

MEIRA (2005) destaca a importância de docentes que assumem um papel de intelectuais críticos e ativistas sociais. O referido autor salienta que estes docentes mais comprometidos com a realidade passam a ser gestores ou mediadores do currículo e assumem seu papel como intelectuais. Tomando como referência o pensamento dos sociólogos Giroux (1990) e Bourdieu (2001), MEIRA (2005, p.278-279) explica que o termo "intelectual" estaria se referindo a:

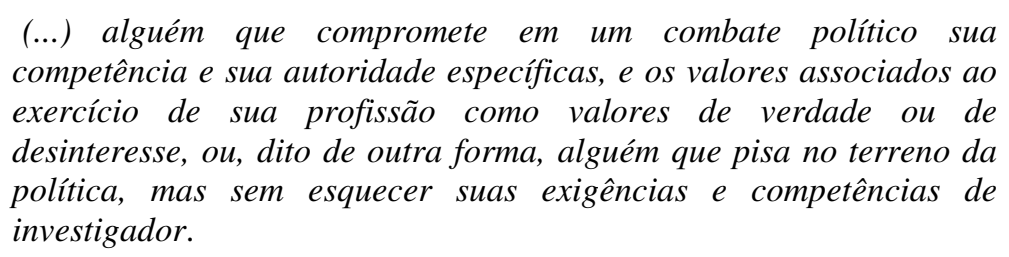
competência e sua autoridade específicas, e os valores associados ao exercício de sua profissão como valores de verdade ou de desinteresse, ou, dito de outra forma, alguém que pisa no terreno da política, mas sem esquecer suas exigências e competências de investigador.

Muitas vezes a pressão para a mudança de postura da escola, na direção de um currículo que valorize a defesa dos direitos humanos vem dos próprios movimentos sociais, quando estes se encontram fortemente organizados e atuantes na sociedade, como afirmam CARNOY \& LEVIN (1985) e que conseguem persuadir as escolas a se tornarem suas aliadas.

Assim, quando a escola atinge esse grau de maturidade política com seus docentes, é fácil concluir que a lógica proposta pelo autor em referência é factível. O próximo passo será o envolvimento de meninos e meninas nas mesmas lutas que seus mestres, influenciados pela sua postura educativa. Essa influência poderá também atingir os próprios companheiros de trabalho, proporcionando uma adesão coletiva às causas sociais e democráticas que, certamente transformará todo o ambiente escolar e conseqüentemente o seu currículo. 


\subsection{2 - A Contribuição dos Movimentos Sociais para o Processo Educativo rumo a uma Cidadania Ativa}

GADOTTI e ROMÃO (2001, p.13), lembram que “(...) a luta pela cidadania, no campo educacional é a mesma luta pela cidadania que constrói a emancipação humana no conjunto das lutas sociais - pela terra, pela distribuição de renda e reforma agrária, pelo emprego e remuneração digna, pelo direito à saúde, educação, trabalho, segurodesemprego, aposentadoria, etc". Igualdade, solidariedade e democracia efetiva valorizando a diversidade e não a uniformidade são princípios básicos que devem reger a educação. Portanto, o fator comum entre os movimentos sociais e a educação é a cidadania. A História, porém, demonstra que o conceito de cidadania ao longo do tempo nem sempre foi homogêneo, como demonstra GOHN (2001): a Declaração dos Direitos do Homem em 1789 relacionava o direito supremo à propriedade com a existência da cidadania, portanto, o cidadão era aquele suficientemente esclarecido para escolher representantes, mas acima de tudo, era o proprietário de terras, que para os liberais, era o sujeito político burguês. Locke por exemplo, era defensor de diferentes direitos para a burguesia, tida como cidadã, e para os trabalhadores, vistos como não-cidadãos, incapazes de pensar e isentos de racionalidade política.

No século XVIII, observou-se uma mudança nessa concepção e a questão educativa surge com toda força, alimentada por um racionalismo que propunha mudar a ordem social e política atuando sobre a consciência e a instrução. O homem é visto como sujeito histórico que age e modifica a realidade, mas para isso precisa ser livre e consciente. A cidadania é passiva, contrária à concepção original clássica e deve preservar a ordem no convívio social, lembrando o que Foucault (citado pela autora, p.14) chamaria de 'disciplinar os corpos e as mentes para serem governados'.

No século XIX, a cidadania não é conquista da sociedade civil, mas é outorgada pelo Estado. Ela se destina a todos e se resume em educação, mas trata-se de uma cidadania domesticada. Já no século XX, o Estado é o interlocutor oficial da sociedade e regulamentador de direitos, ele inclusive os restringe e cassa, em alguns momentos históricos. A cidadania está condicionada ao projeto burguês que prevê essa relação de deveres para com o Estado. Aliado a isso, aparece o neoliberalismo comunitarista em 
que o cidadão é membro de uma comunidade de interesses e deve a esta a sua solidariedade. A educação conservadora educa para a cooperação geral com o sistema. Surge então, outro conceito de cidadania: aquela que está presente nos movimentos sociais - o novo ator social e histórico, que lutam contra tudo o que desilude a sociedade civil, produto da negação dos direitos humanos, do raciocínio capitalista explorador. Suas reivindicações visam atender ao cidadão coletivo e a educação cabe um lugar privilegiado, porque “(...) ela se constrói no processo de luta que é, em si próprio, um movimento educativo" (p.16). Essa nova cidadania chega às mãos dos excluídos e se constrói no cotidiano de suas práticas e da identidade político-cultural construída em suas lutas.

Depois de resgatar o processo histórico no qual os diferentes conceitos de cidadania foram costurados, GOHN (2001) discorre sobre o processo educativo que ocorre fora da instituição 'Escola', mas que, lembrando o que foi discutido com SANTOMÉ (2001), pode ser um importante instrumento de formação para professores e alunos, dado ao seu forte caráter educativo. De acordo com GOHN (2001), ele ocorre dentro de três dimensões:

- A dimensão da organização política, onde a consciência se constrói a partir da agregação de informações dispersas sobre como funciona a máquina pública, possibilitando aos participantes, o acesso "ao como funciona" e quais são os interesses envolvidos. A construção da cidadania coletiva se efetiva a partir da "elaboração de estratégias de formulação de demandas e táticas de enfrentamento dos oponentes" (p.18). É uma nova postura de obtenção de direitos oposta à antiga de demandatários de bens e necessita, portanto, de ferramentas de luta mais organizadas;

- A dimensão da cultura política, que possibilita o acúmulo de experiências a partir da militância nos movimentos sociais. A vivência do passado e do presente tem grande importância na construção do futuro. As experiências do passado como a opressão, a negação dos direitos são resgates imprescindíveis para a leitura do presente e ambos configuram- 
se em "força social coletiva organizada", conforme Thompson, citado por GOHN (2001; p.19);

- A dimensão espacial-temporal “(...) resgata elementos da consciência fragmentada das classes populares, ajudando sua articulação, no sentido gramsciniano da construção de pontos de resistência à hegemonia dominante, construindo lentamente a contra-hegemonia popular", como pensa Gramsci, citado por GOHN (2001; p.21). Isso acontece porque leva o indivíduo a conhecer e reconhecer as condições de vida de determinadas camadas sociais ao longo da história.

Como salienta a referida autora (p.52), "não se trata de um processo apenas de aprendizagem individual, que resulta num processo de politização dos seus participantes (...)" é o desenvolvimento da consciência individual, mas o resultado mais importante é no plano coletivo. A pressão e a resistência da sociedade civil organizada vão provocar mudanças nas relações entre os atores envolvidos, portanto o caráter educativo é duplo, pois tanto a população que reivindica, quanto o governo que controla e é o gestor dos bens públicos demandados, são transformados.

Portanto, conforme a referida autora manifesta na defesa do caráter educativo dos movimentos sociais, trata-se de uma contribuição valiosa para a construção de uma cidadania ativa e não tutelada nos moldes do passado, potencializando ainda mais a capacidade de ação e reação da sociedade se estiver aliada aos processos educacionais formais. Nessa linha, as estruturas tradicionais de poder poderão ser superadas e surgirão indivíduos emancipados. Uma sociedade mais igualitária do ponto de vista dos direitos e deveres poderá ser edificada com essa importante aliança.

\section{4 - A Educação Ambiental em um Currículo Emancipatório}

De acordo com o raciocínio de CASCINO (1998), deve haver espaço para erros e acertos, falhas e conquistas, desejos e insatisfações inerentes a toda pessoa humana se quisermos, através da liberdade de aprender-ensinar, ampliar o exercício de liberdade para a vida em sociedade. Para o referido autor, o desafio de construir um currículo voltado para uma efetiva educação ambiental exige a negação de uma educação para o 
ambiente sem considerar as relações humanas, palco da defesa de nossas idéias, de nossas ações, crenças e anseios. Tampouco se pode imaginar relações pedagógicas baseadas em "ações disciplinarizadas, estanques e fragmentadas".

Na educação formal a preocupação central ficou reduzida à incorporação de conhecimentos relativos ao meio ambiente e à sua conservação. Porém, a incorporação pura e simples dessa consciência ecológica no currículo tradicional é insuficiente para desenvolver uma nova compreensão do mundo, necessária para mobilizar, intervir e reverter os problemas que se apresentam na atualidade. Por outro lado, a confluência de uma pedagogia do ambiente com uma pedagogia da complexidade, seria capaz de levar os alunos a perceber a multicausualidade e as inter-relações que ocorrem ao longo de seu desenvolvimento psicogenético, dentro da realidade da qual ele faz parte (LEFF, 2001).

Ao se referir às estratégias para incorporar os valores ambientais no processo de ensino-aprendizagem, o autor em referência salienta que existem diferentes meios e que a educação formal não é o único caminho. Porém, independente disso, esses valores devem contemplar "desde princípios ecológicos gerais (comportamentos em harmonia com a natureza) e uma nova ética política (abertura para a pluralidade política e a tolerância com o outro), até os novos direitos coletivos e os interesses sociais associados a reapropriação da natureza e à redefinição e centralização do poder na ordem econômica, política e cultural dominante".

A educação ambiental que se espera deve, portanto, incorporar além das preocupações já discutidas, conceitos simples, mas imprescindíveis ao equilíbrio ambiental e à qualidade de vida do Planeta: "cooperação, pluralismo, paz, ética, criatividade, afetividade, resistência, solidariedade, dignidade, coletividade, participação, igualdade, espiritualidade e amor" (CASCINO, 1998; p.22).

A educação ambiental escolar tem um importante papel, pois se trata de uma filosofia de educação que perpassa todas as disciplinas (REIGOTA, 1998), promovendo no ambiente escolar o afloramento de idéias, de alegria, competências, democracia, criticidade, mobilização e transformação a serviço da comunidade a qual pertence, segundo o pensamento. Sendo uma filosofia de vida que tem como fim, a melhoria da 
qualidade de vida de todos e o equilíbrio do Planeta (PHILLIPI JR. \& PELICIONI, 2000 e REIGOTA, 2001), deve estar apoiada numa ética ambiental que pressupõe mais justiça social, eqüidade, democracia e a busca da sustentabilidade, preparando os indivíduos para intervir no mundo do ponto de vista político, econômico, ecológico, social e favorecendo a formação de uma visão crítica e da responsabilidade social, em oposição ao conformismo (REIGOTA, 1999).

As práticas educativas em educação ambiental têm que ter esse caráter emancipador, contrário à manutenção do status quo. Devem ser estimuladoras da participação para serem consideradas democráticas e emancipadoras, críticas e problematizadoras, conforme o pensamento de WESTPHAL (2000) para realizar a "utopia ecológica e democrática" (p.173). E assim como defende essa autora, o educando não pode ser objeto, mas sim sujeito da prática educativa e o educador não deve ter a pretensão de transferir conhecimento ou normas de conduta, sob a alegação de estar buscando mudanças de comportamento. A bagagem do educando, seu modo de vida e suas aspirações são pontos fundamentais na troca constante que deve haver entre educandos e educadores no processo de construção do conhecimento. O programa, as bibliografias e as aulas expositivas típicas do currículo padrão e que servem para conter professores e alunos não podem se sobrepor a essa forma emancipadora de produzir conhecimento e de refazer a sociedade como afirma SHOR (1986).

Se por um lado, “(...) o contexto da transformação não é só a sala de aula, mas encontra-se fora dela", por outro, se o processo educativo for libertador, os protagonistas desse processo terão nas mãos a transformação também do contexto fora da sala de aula, nas palavras de FREIRE (1986, p.46). Lembrando o que disse REIGOTA (1998), a escola tem essa importante função social de formar cidadãos e, por isso, mesmo não sendo o único, historicamente tem sido indicada como o melhor local para discutir e aprender sobre as grandes questões dos nossos tempos. Segundo o autor, porém que é preciso que ela tenha a preocupação de se renovar pedagogicamente, sempre que necessário, de forma a contemplar diferentes momentos de ensinoaprendizagem, de forma que a conscientização para os problemas que afetam a humanidade e o conhecimento acerca dos mesmos, de suas interligações e das responsabilidades individuais diante deles, possam trazer a perspectiva de um futuro sustentável para todos. 


\subsection{1 - A Construção de Ambientes Saudáveis nas Escolas cruzando os Caminhos da EA Escolar: Do Cenário Mundial às Experiências Locais na Rede Municipal de Ensino de São Paulo}

Antes de situar a escola como um dos cenários propícios para práticas orientadas para a aquisição da saúde individual e coletiva, parece produtivo discutir num primeiro momento sobre a relação entre a saúde, o meio ambiente e as condições de vida e a própria educação. Esse vínculo indissolúvel já foi postulado por diversos autores, entre eles MINAYO et al (2000), BUSS (2000) e CASTELLANOS (1998) ancorados também, pelos documentos produzidos ao longo das várias Conferências Mundiais de Saúde, comentadas por BYDLOWSKI et al (2004) e sintetizadas no trabalho de SEBASTIANI (2004) a seguir apresentadas:

Como observaram esses autores, o conceito de saúde e os meios para alcançá-la foram sendo reformulados a cada um desses encontros, no sentido de tornarem-se mais completos, agregando fatores a princípio desconsiderados em sua definição primitiva.

Em Alma-Ata (1979), por exemplo, considerou-se a saúde como um estado de completo bem estar físico, mental e social, enfatizando-se a necessidade de ações conjuntas no campo social e econômico para obtê-la.

Em 1986, na Conferência Mundial de Saúde em Ottawa, o fator ambiental apareceu como componente essencial para a saúde. Em 1988, na Conferência de Adelaide, as políticas públicas priorizando as áreas da saúde da mulher, alimentação e nutrição, tabaco e álcool e a criação de ambientes saudáveis, surgiram como meios necessários para atingir uma vida saudável.

A Conferência de Sundswal (1991) ratificou os pressupostos da Carta de Ottawa, quando considerou o ambiente e a ecologia como fatores relevantes na promoção da saúde, bem como as questões econômicas, políticas e culturais que interferem no desenvolvimento sustentável e na eqüidade - compromisso de todos. 
A saúde como direito humano fundamental foi defendida na Conferência de Jacarta (1997) e, portanto, ressaltou-se a importância de se colocar num primeiro plano, dentro das políticas de desenvolvimento, os programas de promoção e educação em saúde.

A preocupação com comportamentos socialmente responsáveis em todos os níveis, a busca por melhores condições de vida e uma maior eqüidade, surgiram na Conferência do México (2000), ao mesmo tempo em que se suscitava a relevância de um maior investimento na promoção de saúde através do empoderamento das comunidades para que elas busquem o atendimento de suas necessidades de saúde. A inclusão da promoção em saúde nos currículos de diversos níveis, o incentivo à participação de diferentes setores no planejamento de ações voltados à promoção de saúde e a capacitação dos profissionais nesse sentido, foram recomendados.

Em 2005, na 6 ${ }^{a}$ Conferência Mundial de Promoção de Saúde em Bangkok, a Carta de Bangkok para a promoção da saúde em um mundo globalizado, foram formulados quatro novos compromissos: fazer com que a promoção da saúde fosse um elemento fundamental na agenda de desenvolvimento mundial; uma responsabilidade central para todos os que governam; que o foco fosse principalmente nas comunidades e na sociedade civil; a exigência de boas práticas empresariais (CATFORD 2007).

Para BRASIL (1996), também o conceito de "promoção de saúde" foi sendo construído gradativamente em cada um desses encontros científicos. A Carta de Ottawa, por exemplo, a definiu como sendo "o processo de capacitação da comunidade para atuar na melhoria da sua qualidade de vida e saúde, incluindo uma maior participação no controle deste processo".

Em uma análise sobre os vinte anos da Carta de Ottawa, HILLS \& McQUEEN (2007), reconheceram que esse documento, com seus pontos fracos e fortes não foi tão normativa como deveria para que o desenvolvimento posterior da promoção da saúde 
seguisse de maneira sistemática cada uma das áreas de intervenção. Tratava-se mais de uma chamada para a adoção de uma visão ampla de promoção da saúde com o objetivo de colocá-la inequivocadamente no centro do trabalho em que confluíam esse cinco campos de ação: a elaboração de políticas públicas saudáveis, a criação de ambientes favoráveis à saúde, o fortalecimento da ação comunitária, o desenvolvimento das atitudes pessoais e a reorientação dos serviços de saúde. Apesar disso, essa Carta ainda configura-se como uma fonte de inspiração para a comunidade mundial que trabalha com a promoção de saúde, ou a "pedra angular" dentro desse movimento, conscientes de que "documentos sozinhos", não têm o poder de transformar a saúde em todo o Planeta, já que em muitos casos suas expectativas superam a capacidade "de simples mortais" concretizá-las, prevalecendo o atual cenário político, social e econômico mundial.

A preocupação com a saúde dos ambientes e de toda a problemática que a envolve, inclusive a relação estreita desta com a saúde da população, não é recente, como argumenta RIBEIRO (2004), pois tem acompanhado a humanidade desde a Antiguidade. Apesar disso, como a própria autora lembra, somente na segunda metade do século XX é que se criou e oficialmente essa subárea da Saúde Pública para tratar especificamente dessa inter-relação entre saúde e meio ambiente, que foi denominada de 'Saúde Ambiental'. Em 1999, O Ministério da Saúde definiu esse campo de atuação da saúde pública, como sendo aquele "que se ocupa das formas de vida, das substâncias e das condições em torno do ser humano, que podem exercer alguma influência sobre a sua saúde e o seu bem-estar". (RIBEIRO, 2004; p.71). A referida autora também se reportou à definição da Organização Mundial da Saúde, que em 1993, a definiu como sendo:

(...) todos aqueles aspectos da saúde humana, incluindo a qualidade de vida, que estão determinados por fatores físicos, químicos, biológicos, sociais e psicológicos no meio ambiente. Também se refere à teoria e prática de valorar, corrigir, controlar e evitar aqueles fatores do meio ambiente que, potencialmente, possam prejudicar a saúde de gerações atuais e futuras (p.71). 
Como expressa a autora supracitada, são muitos e variados os fatores ambientais que interferem na saúde humana, o que determina, não apenas a complexidade das interrelações existentes, mas também as estratégias que devem ser desenvolvidas para resolver os problemas decorrentes das mesmas. Nesse sentido, FRANCO NETTO \& CARNEIRO (2003, p.31), apresentam um novo campo de atuação surgida no Brasil em 2003: a Vigilância Ambiental em Saúde (aquela que se preocupa com os riscos ambientais), que tem como uma das atribuições mais importantes, fiscalizar os processos de produção, integração, processamento e interpretação de dados, a fim de conhecer os problemas de saúde relacionados com os fatores ambientais e execução de ações voltadas às atividades de promoção de saúde, prevenção e controle de doenças.

A VAS foi também definida pelo Ministério da Saúde, como: "um conjunto de ações que proporciona o conhecimento e a detecção de qualquer mudança nos fatores determinantes e condicionantes do meio ambiente que interferem na saúde humana, com a finalidade de identificar as medidas de prevenção e controle dos fatores de risco ambientais relacionados às doenças ou outros agravos a saúde" (BRASIL, 2001). Assim, "o campo de atuação da Vigilância Ambiental em Saúde (VAS) está representado pela interface entre saúde e ambiente, o chamado campo da saúde ambiental".

FRANCO NETTO \& CARNEIRO (2003), ressaltam que, é fundamental que aconteça uma real articulação entre os diferentes setores governamentais (saúde, meio ambiente, educação, entre outros) em todos os níveis de governo, tendo como aliado também o setor privado e as comunidades envolvidas, de tal forma que, ao assumirem cada qual suas responsabilidades e ações no tocante aos problemas de saúde e ambiente, possam fazê-lo de maneira integrada, garantindo uma melhor eficiência dessas ações. Uma parceria recomendável no nível local seria a os Conselhos de Saúde, Meio Ambiente, Fóruns de Agenda 21 Local, Secretarias de Educação, entre outros.

A história da promoção da saúde na escola, como explicita SILVEIRA (2000) remonta ao século XVII, na Europa, época em que havia uma preocupação centrada nas condições de salubridade dos ambientes escolares, na saúde dos alunos e na divulgação 
de hábitos que promovessem a saúde individual. A autora prossegue sua análise passando pelo século XIX, quando alguns países como a Alemanha e os Estados Unidos resolveram delegar oficialmente às escolas, a missão de preparar os indivíduos para "uma maior aptidão ao trabalho e para as obrigações impostas pela cidadania", através da educação para desenvolver novos hábitos de higiene, capazes de melhorar “(...) os corpos pela ginástica, pela boa alimentação, pela redução da estafas pelos maus hábitos de estudos e de posicionamento nas carteiras escolares" (p.11).

No Brasil, conforme SILVEIRA (2000), o movimento da Escola Nova, na década de 20, considerava que a escola poderia transformar a sociedade através de ações no campo da saúde e no decorrer das outras décadas, a partir dos anos 70, ampliaram-se os debates sobre a promoção da saúde no cenário educacional e como a autora salienta, com o cuidado de não atribuir unicamente à escola, a missão de resolver as complexas questões sociais, econômicas e culturais determinantes da qualidade de vida da população. Assim, começou-se a se instalar um movimento em prol do fortalecimento da cidadania, que deveria buscar, de forma organizada, a criação de condições favoráveis à qualidade de vida e conseqüentemente à saúde. Nesse sentido, convergem as posições da referida autora com aquelas já referenciadas anteriormente neste trabalho, acerca dos objetivos e ações comuns entre a escola e os movimentos sociais, tendo em vista que a escola é só mais uma das muitas esferas possíveis para a construção da cidadania.

Observou-se na década seguinte, a consolidação da idéia de que as crianças e jovens deveriam ter prioridade nas políticas de saúde nas diferentes sociedades e países, e que a promoção da saúde deveria estar atrelada a um processo de educação amplo, envolvendo diferentes segmentos da população e de instituições governamentais e não governamentais. A OPAS e OMS em 1995 salientaram que muitos esforços se somaram nesse caminho e cita a iniciativa da Organização Mundial da Saúde (OMS), da Organização Panamericana de Saúde (OPAS) e do Fundo das Nações Unidas para a Infância das Nações Unidas (UNICEF), que publicaram documento, onde foram aferidos "os resultados de uma pesquisa internacional sobre a complexidade da aprendizagem na área da saúde - fora e dentro da escola -, o diagnóstico da Educação 
em saúde no conjunto dos países investigados e as propostas de estratégias para fortalecê-la nos sistemas educativos". O diálogo entre países latino-americanos nos anos subseqüentes foi importante para que novos projetos e estratégias conjuntas nos campos da saúde e da educação pudessem ser traçados a partir de experiências bem sucedidas com essa visão integral de educação em saúde na escola (SILVEIRA,2000).

Assim, em 1995, surgiu “A Iniciativa Regional Escolas Promotoras de Saúde” da Organização Panamericana de Saúde, Oficina Regional da Organização Mundial da Saúde, "em resposta à situação, prioridades e perspectivas em saúde escolar dos Estados Membros da Região das Américas". (OPAS 2003). Essa iniciativa tinha como foco a melhoria da qualidade de vida e do bem estar coletivo das crianças, jovens, docentes e demais membros das comunidades educativas.

Dois anos depois, também a Resolução da Primeira Conferência da Rede Européia de Escolas Promotoras de Saúde, ocorrida na Grécia afirmava que todas as crianças e jovens da Europa tinham o direito e deveriam ter a possibilidade de estudar em uma escola promotora de saúde. A função dessa Rede era atuar positivamente, tanto na comunidade educativa quanto na local, pois criar-se-ia um marco social muito favorável capaz de influir nas idéias, percepções e ações de todos os que vivem, trabalham, participam e aprendem na escola. Advém desse marco, um clima positivo que influi na forma de estabelecer relações e nos processos decisórios que afetam aos jovens, assim como o modo em que eles desenvolvem seus valores e atitudes (OMS 1997).

WILLS et al (2007) apresenta exemplos de países onde as visões das crianças e adolescentes são reconhecidas como cruciais para o desenvolvimento das políticas públicas. Segundo a autora, os países nórdicos têm uma longa tradição de consulta às crianças e adolescentes, dando voz a eles nas pesquisas e nas decisões que afetam suas vidas. Já os Estados Unidos ainda não ratificaram a Convenção das Nações Unidas sobre os Direitos da Criança de 1989, mas, para ela, há evidências de que a América está adotando medidas em favor desses direitos, através do trabalho da Colaboração Nacional para a Juventude, a Corporação Carnegie, o Fórum Americano de Políticas para os Jovens e um conjunto amplo de conselhos e projetos sobre juventude por todos 
os Estados americanos. A Agência Pública de Saúde do Canadá está tentando assegurar que os jovens tenham oportunidades de se envolver em decisões sobre o seu desenvolvimento pessoal, bem como nas macro políticas e serviços de saúde. $\mathrm{Na}$ Austrália, a Associação Australiana para o bem-estar da Saúde da Criança, é uma organização nacional para pais, profissionais e comunidades que trabalham juntos para assegurar as necessidades sociais e emocionais das crianças e jovens e suas opiniões são valorizadas e reconhecidas no Sistema de Saúde Australiano. Na Nova Zelândia, têm aumentado a atenção dada ao envolvimento dos jovens nas decisões através do Ministério do Desenvolvimento da Juventude e de outros órgãos governamentais voltados para a participação de crianças e jovens. WILLS et al (2007), no entanto, considera que apesar de iniciativas em termos de políticas e práticas enfatizando a promoção da saúde de crianças e jovens no mundo ocidental, estas ainda "nadam contra a corrente" em relação ao discurso que prevalece na maioria dos países sobre a saúde pública e a promoção de saúde.

As escolas têm se tornado de forma crescente, o foco para muitos trabalhos de promoção de saúde. De acordo com WILLS et al (2007), muitos países de continentes desenvolvidos têm programas de 'escolas saudáveis'. As escolas saudáveis são um caminho rápido para melhorar a saúde mental, física, social e emocional das crianças e adolescentes, numa visão holística e integrada. Essas escolas têm designadas por nomes diferentes nas diversas partes do mundo. Como afirma a autora, todos os países compartilham similaridades na proposta, por exemplo, de integrar saúde dentro do dia a dia das escolas tanto formalmente, quanto informalmente, aprimorando o currículo e promovendo habilidades para ajudar os estudantes a fazer escolhas saudáveis.

Um exemplo prático de construção de uma escola saudável foi apresentado por uma educadora da Finlândia, em uma Conferência de Promoção e Educação em Saúde ocorrida no Canadá em 2007 (SAVOLA, 2007). Trata-se da Escola Soukka, pioneira no desenvolvimento de seu próprio projeto de saúde em 2005: A equipe composta por diretor, professores, funcionários, pais e alunos, contando ainda com a parceria de um profissional da área da saúde (enfermeira) discutia regularmente nas reuniões pedagógicas, nas associações de pais e nas salas de aula com os alunos, práticas favoráveis à saúde e as novas idéias que surgiam nos grupos passavam a ser o alvo a ser 
alcançado por todos. Ao mesmo tempo, eram realizadas pesquisas sobre bem-estar na escola, conduzidas por professores e alunos e também as visões dos pais sobre as práticas de promoção de saúde na escola eram investigadas. Baseados nos resultados das pesquisas e nas discussões ocorridas nas reuniões ao longo do projeto, foram decididas as prioridades para os anos de 2006 e 2007 e entre elas, estava uma maior participação dos alunos. A equipe de promoção de saúde avaliava o projeto duas vezes ao ano verificando os progressos e próximos objetivos a serem alcançados. A escola publicou o projeto e as autoridades da saúde e da educação foram informadas sobre os resultados. Até a mídia foi acionada, pois um dos objetivos da escola era atingir as escolas vizinhas no sentido destas também desenvolverem um trabalho holístico e sistemático de promoção de saúde. Trabalhos com resultados semelhantes foram também apresentados pelo Japão, Coréia, Reino Unido, França, entre outros.

Assim, o movimento das Escolas Promotoras de Saúde foi se ampliando para outras regiões do Planeta, e também no continente Asiático a partir de 2001, em Hong Kong (China), centenas de escolas receberam o status de "escolas promotoras de saúde" pela Organização Mundial da Saúde (CHEHP 2006).

No continente africano, a OMS elaborou ainda uma Estratégia Regional de Promoção da Saúde, durante o biênio de 2000-2001, incentivou e orientou a criação de escolas promotoras da saúde, apoiando 15 países na promoção da iniciativa das escolas promotoras da saúde (OMS 2002).

No Brasil, a partir da década de 90, o Ministério da Educação (MEC) elaborou o Plano Decenal de Educação para Todos (1993-2003), atendendo à Constituição Federal (1988) que estabelecia a necessidade de se elaborar parâmetros curriculares nacionais para que o ensino obrigatório estivesse em consonância com os ideais democráticos e alcançasse uma real qualidade.

Desta forma, resgatando o que já foi abordado por SILVEIRA (2000) acerca do processo de elaboração dos parâmetros curriculares nacionais, nos quais encontram-se inseridos os temas transversais (Ética, Saúde, Meio Ambiente, Trabalho e Consumo, Orientação Sexual e Pluralidade Cultural), após consulta às propostas curriculares dos Estados e Municípios, o MEC elaborou uma versão preliminar desses parâmetros, a 
qual foi submetida à apreciação de docentes de Universidades públicas e privadas, Secretarias Estaduais e Municipais de Educação, Sindicatos e outras entidades ligadas ao Magistério.

Após a análise e discussão desses setores e mesmo sob críticas de educadores que ainda assim sentiram-se excluídos do processo, como lembra a referida autora, os parâmetros foram concluídos. Neles, foram traçadas diretrizes para todas as áreas do conhecimento, bem como para aqueles temas considerados importantes para a cidadania e que freqüentemente eram "esquecidos" ou pouco explorados pelas disciplinas tradicionais, os chamados - temas transversais - já especificados aqui, anteriormente.

De acordo com os parâmetros, a função desses temas transversais, seria a de possibilitar à Escola cumprir eficazmente o seu papel de educar para a transformação da realidade, fomentando discussões e práticas entre educadores, educandos e comunidade que marcassem posições sobre as questões sociais relevantes do nosso tempo. No entanto, o que se observa na maioria das escolas é uma realidade diferente dessas expectativas, pois normalmente os temas transversais acabam sendo tratados por disciplinas específicas e de forma estanque, sem comunicação com outras áreas do conhecimento ou com os próprios conteúdos desenvolvidos por essas mesmas disciplinas.

Assim como em SILVEIRA (2000), o tema transversal "Saúde", será aqui tratado com especial destaque e para ele, os parâmetros reservam uma visão integral de saúde, considerando as condições físicas do meio ambiente, como a qualidade do ar e da água que consumimos, a produção industrial, sobretudo no que tange aos equipamentos bélicos e nucleares, os hábitos de consumo e miséria, a desnutrição, os diferentes estilos de vida e a dinâmica de inserção no mundo do trabalho envolvendo os diferentes segmentos da população.

Os parâmetros também enfatizam as questões éticas relativas ao direito à vida e à saúde e as responsabilidades individuais e sociais, bem como dos setores públicos e privados.

Considerando-se a saúde como a OMS a define - o pleno bem-estar físico, mental e social - e as pesquisas realizadas acerca da relação entre a taxa de mortalidade 
infantil e a escolaridade das mães, percebe-se o estreito vínculo entre a saúde e os níveis de educação dos indivíduos, como também observa SILVEIRA (2000), pois embora a educação sozinha não seja capaz de criar e sustentar as bases necessárias para a aquisição da saúde global da população, sua contribuição é realmente significativa para a melhora da qualidade de vida e conseqüentemente da saúde.

Para a referida autora, a visão desse documento explicita as proposições da OMS, quanto ao que se considera "uma escola promotora de saúde". São escolas que:

- Consideram todos os espaços do prédio escolar como ambientes de aprendizagem e promovem ações que tornem esses ambientes saudáveis;

- Reconhecem a estética do entorno físico da escola como importante para a saúde física e mental de educandos e educadores;

- Têm uma visão de saúde que percebe a integração entre os aspectos físicos, psíquicos, sócio-culturais e ambientais;

- Criam espaços de participação efetiva dos alunos

- Incluem em todas as áreas do conhecimento temas relacionados à saúde;

- Procuram investir na auto-estima e na autonomia de seus integrantes, por serem elementos imprescindíveis à promoção da saúde;

- Consideram importante a promoção da saúde entre todos os segmentos da comunidade escolar;

- Têm uma visão ampla dos serviços de saúde voltados para a escola;

- Incentivam a adoção de modos de vida saudáveis e propiciam no espaço escolar, situações concretas para a prática de atividades saudáveis;

- Criam condições para que os educadores se envolvam diretamente na elaboração do projeto pedagógico da educação para a saúde;

- Estabelecem inter-relações no projeto escolar. 
É importante salientar que, tomando como base os parâmetros curriculares nacionais, diversas iniciativas voltadas para o tema "Saúde" em diferentes gestões políticas, foram sendo desenvolvidas nas Unidades Escolares em muitos Estados e Municípios brasileiros (incluindo o Estado e Município de São Paulo), desde a publicação desse documento. No entanto, não é pretensão deste trabalho aprofundar-se ou deter-se exclusivamente nesse aspecto da educação, por isso optou por ilustrar apenas alguns exemplos dessas iniciativas que estão ocorrendo no momento atual nas Escolas Municipais, alvos desse estudo. É o caso do Projeto "Escola Promotora de Saúde", coordenado pela Área Técnica de Saúde da Criança e do Adolescente da CODEPPS/SME em parceria com a Secretaria Municipal de Educação de São Paulo (gestão 2005-2008). Esse projeto tem como objetivo, enfrentar e superar os problemas detectados pela Secretaria Municipal de Educação (SME), relativos à saúde da infância, na faixa de 0 a 6 anos entre os alunos integrantes das U.E.s da Capital, que 28\% dessas crianças apresentam anemia; 72,9\% , lesões e cáries dentárias; 10,4\%, problemas de visão; $20 \%$, verminoses; $8 \%$ desnutrição; $9,7 \%$, obesidade; $4,3 \%$, baixa estatura (SÃO PAULO, 2007). Ainda de acordo com a Prefeitura de São Paulo (SÃO PAULO, 2005), estudos realizados por Universidades sobre a saúde dos jovens da rede municipal, revelaram que $57 \%$ deles têm anemia ferropriva; $70 \%$ apresentam cáries; $30 \%$, problemas auditivos; $30 \%$ dematoses e 10,5\%, obesidade. Tais estudos constataram situações alarmantes, pois também mostraram que dentre os alunos do $4^{\circ}$ ano do Ciclo II (antiga $8^{\text {a }}$ série), 83\% consomem bebida alcoólica, 49\% das alunas fumam, contra $27 \%$ dos adolescentes do sexo masculino.

Em função desse cenário preocupante, a SME, em parceria com a Secretaria Municipal de Saúde (SMS), realizou em Maio de 2005, a $1^{\text {a }}$ Semana Promotora de Saúde nas escolas com diversas atividades voltadas para o público escolar e entorno, que envolviam questões sobre sexualidade, gravidez na adolescência, DST/AIDS, abuso de drogas e álcool, terapias comunitárias, práticas corporais chinesas e ações de saúde bucal, ocular, auditiva, antropométrica, etc.

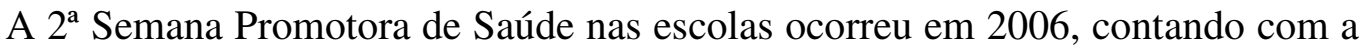
parceria de SME e SMS, além do apoio da USP, UNIFESP, Universidade São Marcos, Universidade São Camilo, Universidade Anhembi-Morumbi. Segundo a Prefeitura (SÃO PAULO, 2006 e 2007a), as diversas atividades promovidas, visavam promover "a 
reflexão sobre a saúde e a qualidade de vida e também atuar sobre as causas e possíveis soluções para os problemas existentes na comunidade escolar e do seu entorno".

Em Agosto de 2007, a Prefeitura de São Paulo anunciou nos meios de comunicação de massa, que pretendia levar para as Unidades Escolares nos finais de semana, uma equipe de profissionais da Saúde para realizarem exames e encaminhamentos durantes o atendimento dos alunos dessas UEs. Embora seja uma iniciativa importante, levando-se em consideração todas as reflexões aqui apresentadas sobre a promoção de saúde na escola, esse movimento recente e que ainda está sendo implantando, suscita dúvidas quando à sua eficiência e principalmente sobre a sua continuidade, tendo em vista as inúmeras deficiências no sistema de saúde municipal que são de conhecimento público, sobretudo no que se refere à falta de profissionais para o atendimento da população nas próprias Unidades de Saúde, de recursos (remédios, equipamentos) e à demora para a realização de exames e procedimentos mais complexos desses pacientes. Além disso, precisa estar afinado com as demais ações da escola, combinando atividades curriculares, formação de professores, envolvimento da comunidade escolar e de seu entorno no cotidiano escolar, investimento na segurança alimentar e na criação e manutenção de ambientes adequados e saudáveis para todos, questões que ainda precisam ser equacionadas em grande parte das escolas. Também é importante lembrar que tais ações requerem uma estrutura sólida (investimentos financeiros, recursos humanos disponíveis e qualificados, integração inter-secretarial e inter-setorial para ações conjuntas e articuladas) e mecanismos legais para garantir a sua continuidade, tendo em vista que programas como este não podem ficar ao sabor das 'vontades políticas' e da incerteza gerada pela instabilidade dos partidos políticos que se alternam no poder.

Finalmente, conforme as discussões ora apresentadas permitem afirmar, de forma geral, as escolas promotoras de saúde desenvolvem-se ao redor do mundo mobilizadas por um mesmo espírito. De acordo com a OMS (1998, citada em OPAS 2003a), elas:

(...) inculcam o sentido de responsabilidade social em crianças e jovens, desenvolvendo neles a capacidade de resolver conflitos mediante o diálogo e a negociação como fatores preventivos da violência e instrumentos de convivência harmônica. Crianças e jovens desejam sentir- 
se úteis e estão dispostos a trabalhar na comunidade, nos hospitais, com pessoas idosas ou com crianças menores. Estas atividades, que estimulam seu espírito de compromisso social e comunitário ao mesmo tempo em que lhes permitem utilizar de forma criativa o tempo livre, serão mais efetivas quanto mais integradas estão ao processo de aprendizagem escolar.

É o que também afirmam a OMS (1997) e PELICIONI (1998): as crianças e jovens que freqüentam escolas promotoras de saúde desenvolvem um espírito crítico, refletindo sobre valores, hábitos e a realidade social que favorece a saúde e o desenvolvimento humano, já que têm como fundamento, vários princípios. Dentre eles, tendo em vista os aspectos já discutidos neste trabalho sobre democracia participativa, educação emancipatória, protagonismo infanto-juvenil e empowerment, currículo e sustentabilidade ambiental, que se harmonizam perfeitamente com tais princípios, aqui serão destacados os seguintes:

- Democracia: Os princípios democráticos fomentados pela Escola Promotora de Saúde (EPS) favorecem a aprendizagem, o desenvolvimento pessoal, social e também da saúde;

- Igualdade: A igualdade é vista como algo inerente à experiência educativa e os estudantes dessas escolas não estarão sujeitos à situações de opressão, medo ou outras formas de constrangimento. Todos os alunos terão oportunidades iguais de ensino e serão preparados para se desenvolverem plenamente.

- A capacidade para a ação: a EPS propicia a troca de experiências entre os jovens e cria um entorno onde toda a comunidade educativa se sente útil, trabalhando juntos para alcançar objetivos comuns. Quanto aos jovens, estes são preparados para, a partir de suas concepções e desejos, decidirem sobre suas próprias vidas e as condições que as regem. $\mathrm{O}$ que torna possível essa participação consciente nos processos decisórios são "as políticas e práticas educativas altamente qualificadas";

- Entorno escolar: representado pelos aspectos físicos e sociais da escola, é um fator imprescindível para a promoção e manutenção da saúde e exige planejamento em saúde e seguridade, de forma que a aplicação das ações seja contínua e que a gestão das mesmas seja adequada;

- Currículo: É através dele que os jovens deverão adquirir hábitos importantes para suas vidas no presente e no futuro, exercitar sua capacidade inventiva, aprender e compreender e, ao mesmo tempo, inspirar professores e demais profissionais da escola estimulando-os a se desenvolverem pessoal e profissionalmente; 
- Formação do professorado: considera-se que investir na formação do professor é propiciar ganhos não apenas para a educação, mas também para a saúde. A formação inicial e a permanente devem ser garantidas por lei, assim como os incentivos necessários, utilizando o marco conceitual das EPS;

- Comunidade local: Os pais e os demais segmentos da comunidade local são importantes parceiros na promoção da saúde na escola, criando possibilidades para que os alunos exerçam sua cidadania, atuando em prol de suas comunidades. Assim, o estabelecimento dessa parceria é capaz de gerar um entorno físico e social favorável à saúde;

- Desenvolvimento sustentável: todas as esferas do poder público devem estar comprometidas com a promoção da saúde nas escolas, alocando os recursos necessários para tanto. Isto propiciará, a longo prazo, o desenvolvimento das escolas e de suas comunidades locais, de tal forma que estas últimas se tornarão um importante recursos para as primeiras. 


\section{II - OBJETIVOS}

- Investigar a existência de projetos e/ou ações voltados para a educação ambiental e o protagonismo infanto-juvenil;

- Verificar se a preocupação com a educação ambiental e o protagonismo infanto-juvenil está expressa nos objetivos dos projetos políticos pedagógicos realizados nas escolas de 2000 a 2006;

- Conhecer e analisar as representações dos educadores, educandos e pais acerca da educação ambiental, da importância da democracia e do protagonismo infanto-juvenil na escola e verificar de que forma se deu a participação de cada um desses grupos para o fortalecimento desses mecanismos dentro e fora do universo escolar.

- Investigar se houve contribuição desses projetos e ações para a melhoria da saúde ambiental e da qualidade de vida da comunidade educativa;

- Identificar possíveis dificuldades e impedimentos para a criação, implementação e continuidade dos projetos dentro das escolas e em que âmbito elas se encontrariam;

\section{Cenário de estudo:}

Foram escolhidas dez escolas da Rede Municipal de Ensino de São Paulo, sendo seis delas integrantes das Coordenadorias de Educação de Itaquera e quatro da Coordenadoria de Educação da Penha, regiões localizadas na zona leste da Cidade de São Paulo. Tal escolha se deveu ao fato da autora, conforme já mencionado, ter atuado como formadora ou como integrante do quadro docente dessas escolas, o que facilitaria o contato com as Unidades e o reconhecimento dos cenários a serem encontrados nas mesmas. 


\section{III - METODOLOGIA}

Trata-se de uma pesquisa qualitativa, que, segundo diversos autores, entre eles, IERVOLINO \& PELICIONI (2001) é utilizada com freqüência em pesquisas da área de saúde, conforme aparece na literatura internacional, permitindo detectar registros do contexto sócio-cultural, para entender e interpretar o comportamento humano.

Em virtude de encontrar-se imersa no meio estudado, onde também desenvolve suas atividades profissionais, a pesquisadora optou pela pesquisa-ação, muito usada "enquanto linha de pesquisa associada a diversas formas de ação coletiva (....)" (THIOLLENT 2000, p.7). Segundo o autor, essa metodologia visa resolver ou, pelo menos esclarecer os problemas que existem no cenário observado. As ações intencionais dos atores envolvidos são acompanhadas durante o processo de pesquisa, a fim de "aumentar o conhecimento dos pesquisadores e o conhecimento ou 'nível de consciência' das pessoas e grupos considerados." (p.16). Neste contexto, THIOLLENT (2000) afirma que pesquisadores e pesquisados que vivem a mesma realidade, participam e colaboram uns com os outros.

\section{População alvo:}

A comunidade escolar compreendida pela equipe técnica (diretores, coordenadores pedagógicos e assistentes de direção), professores, alunos e pais;

Esperava-se que pelo menos um integrante da equipe técnica de cada Unidade pudesse responder ao questionário e em quatro escolas essa expectativa não foi alcançada.

Quanto ao número de professores, previa-se que este seria variável, o que se confirmou, pois em cada Unidade, os professores optam livremente pela Jornada de trabalho e neste caso, havia a preferência pelos optantes pela Jornada Especial Integral 
(JEI), ou seja, aqueles que possuíam um 'horário coletivo destinado ao estudo e desenvolvimento de projetos na Escola. Levando também em consideração que as Unidades Escolares podiam ter de dois a quatro grupos de JEI, cujo número de professores também não é fixo, caberia às equipes técnicas (Direção, Assistentes e Coordenadores Pedagógicos) a indicação de qual desses grupos estaria disponível para participar desta pesquisa, de acordo com a conveniência da Escola.

Com relação aos pais e alunos, esperava-se trabalhar com pelo menos dois integrantes de cada categoria em cada Unidade Escolar, no entanto, essa expectativa não se consolidou em todas as escolas, já que alguns pais desistiram e em outras, apenas um aluno ou um pai se dispôs a participar. Foi dada a preferência para alunos que tivessem participado de projetos voltados ao protagonismo infanto-juvenil, tais como o Orçamento Participativo Criança (OP-Criança) ou das Conferências Infanto-Juvenis do Meio Ambiente, na qualidade de delegados, conselheiros, integrantes do "grupo faísca", ou ainda de outros projetos nascidos no interior da Escola com as mesmas características e seus respectivos pais. A indicação destes também ficou a cargo da Coordenação Pedagógica, da Direção ou do corpo docente.

Estimava-se que o número total de participantes da pesquisa seria de aproximadamente 100 pessoas e ao final da pesquisa foram computados 118 participantes, sendo 80 professores, 21 alunos, 10 pais e 7 integrantes de equipe técnica.

Os procedimentos metodológicos adotados foram:

- Revisão bibliográfica, a partir de materiais publicados em livros, teses, dissertações, revistas técnicas, artigos de jornais impressos e meio eletrônico tendo como referência o tema e o período estudados.

- Pesquisa de campo fazendo uso de três técnicas: grupo focal aplicado aos professores; entrevista padronizada, aplicada aos alunos e pais e questionário com perguntas abertas e fechadas, aplicado aos membros das equipes técnicas das escolas (diretores, assistentes de direção ou coordenadores pedagógicos), conforme ANEXOS. 
Quanto aos grupos focais, participaram dez escolas, sendo que em duas delas, a pedido da Coordenação Pedagógica, foram envolvidos dois grupos de professores que cumpriam diferentes horários de trabalho coletivo (JEI), totalizando oitenta professores. Todas as sessões foram gravadas e posteriormente transcritas na íntegra, pela pesquisadora.

De forma geral, a maioria dos professores iniciou as sessões de entrevistas coletivas com boa disposição para responder às questões apresentadas. Poucos professores se sentiram acanhados ou desmotivados, mas estes eram estimulados pela animadora a dar a opinião, mesmo quando alegavam estar de acordo com esse ou aquele colega. Em cada sessão também houve a presença de um observador, lugar ocupado por outro pesquisador da área de saúde coletiva.

A falta de um ambiente silencioso e tranqüilo para discussões com o grupo, foi um problema enfrentado na maioria das escolas durante a realização das sessões, pois a entrada constante de funcionários, alunos, professores que chegavam para no novo turno, pais que queriam falar com professores, telefonemas, entre outras coisas, dispersavam, em alguns momentos, a atenção dos participantes e preocupavam a pesquisadora quanto ao tempo previsto das sessões de duas ou três horas-aula (equivalente a cerca de uma hora e meia a duas horas-relógio em média, considerandose que a hora-aula varia de 40 a 45 minutos), para a duração de cada horário coletivo disponibilizado pelas escolas para a realização da pesquisa.

Entretanto, o grupo focal demonstrou ser uma técnica eficaz para extrair dos participantes suas idéias e percepções sobre os temas abordados. Mais do que isto, revelou-se um instrumento interessante e dinâmico para fomentar discussões e reflexões sobre as práticas cotidianas dentro das escolas, seus problemas, necessidades e objetivos contribuindo para o redirecionamento dos planos e projetos, tarefa que, aliás, deveria ser desenvolvida com freqüência nos horários coletivos de estudos e projetos (JEI), mas que, percebeu-se, nem sempre ocorria em parte dessas escolas. 


\section{As questões dos grupos focais versavam sobre:}

I - Dados sobre a formação dos professores (cursos, preferencialmente ligados à educação ambiental, oferecidos pela Rede Municipal de Ensino entre 2000 e 2005): participação dos professores nos cursos, importância do oferecimento de cursos por parte da Rede; avaliação sobre a qualidade dos mesmos; aplicabilidade em sala de aula; dificultadores para o desenvolvimento prático dos conhecimentos adquiridos;

II - Educação e cidadania: papel do educador na escola atual; papel do aluno na escola atual; perfil do aluno que a escola deveria formar; eficiência da escola em trabalhar com temas importantes da atualidade, como sustentabilidade ambiental, violência, corrupção, democracia participativa; percepção sobre responsabilidade pela continuidade ou fracasso dos projetos na escola;

III - Educação ambiental na escola: existência de atividades ou projetos nas Unidades Escolares; inclusão dos projetos de educação ambiental no Projeto Político Pedagógico (PPP) da Escola; estratégias utilizadas para desenvolver os projetos ou ações; a existência de uma Agenda 21 escolar (conhecimento dos educadores; processo de construção e envolvimento da comunidade escolar; percepções dos educadores acerca da saúde ambiental da escola).

IV - Participação dos educadores nos sindicatos e em outras esferas de participação política e social;

V - Protagonismo infanto-juvenil na escola: parecer dos educadores; contribuição dos educadores nos projetos da escola; 


\section{Para as entrevistas com os alunos, as questões propostas versavam sobre:}

I - Democracia na escola: opinião sobre como deveriam ser os processos decisórios; participação dos alunos nas decisões;

II - Oportunidades de participação de crianças, adolescentes e jovens na política das três esferas de poder político do País: percepção dos alunos;

III - Projetos institucionais sobre protagonismo infanto-juvenil na escola nos últimos anos (2000 a 2007), como o OP-Criança, Conferências InfantoJuvenis do Meio Ambiente, Educom.radio e outros concebidos pela própria escola voltados para a saúde e meio ambiente: ocorrência na escola; participação dos alunos; percepção acerca da contribuição desses projetos para o desenvolvimento da cidadania e melhoria na qualidade de vida dos mesmos; percepção sobre a saúde ambiental na escola; percepção sobre a responsabilidade ou fracasso desses projetos na escola;

\section{Com relação às entrevistas com os pais, as questões referiam-se a:}

I - Projetos voltados para a cidadania na escola: conhecimento dos pais sobre sua existência; importância dos mesmos na escola; contribuição dos pais para a educação ambiental e desenvolvimento da cidadania dos filhos; conhecimento dos pais sobre a participação e a opinião de seus filhos sobre esses projetos; percepção quanto à responsabilidade pela continuidade ou fracasso dos projetos na escola;

II - Participação dos pais na escola: ocorrência e forma; incentivo da escola;

III - Saúde ambiental: concepção dos pais; percepção dos mesmos em relação ao ambiente escolar dos filhos; 


\section{Constavam do questionário aplicado às equipes técnicas:}

I - Dados sobre a escola: número de turnos, alunos atendidos, rendimento escolar.

II - Informações sobre o cargo, a formação e tempo de trabalho na escola

III - Problemas da escola, busca de soluções

IV - Oferecimento e participação em cursos de formação no período de 2000 a 2005; opinião sobre os cursos.

V - Sobre projetos de protagonismo infanto-juvenil no período de 2000 a 2005: conhecimento e importância; ações na escola decorrentes desses projetos; dificuldades e facilidades para implantá-los na escola; Ocorrência das duas etapas do OP-Criança na UE, participação no Seminário de preparação das Conferências Infanto-Juvenis do Meio Ambiente na escola; ocorrência das duas etapas.

VI - Agenda 21 e Agenda 21 Escolar: conhecimento, existência na escola, processo de construção; ambiente saudável na escola: percepção, sugestões de ações e projetos para torná-lo mais saudável; facilidades para implantar essas sugestões.

Os questionários foram entregues juntamente com os TCLE em 2006 nas escolas para os integrantes das equipes técnicas de todas as UEs (Diretor, Assistente de Direção, Coordenadores Pedagógicos), por ocasião da realização dos grupos focais com os professores. $\mathrm{O}$ mesmo foi lido junto com a pesquisadora para dirimir qualquer dúvida sobre o seu preenchimento ou conteúdo. Foi esclarecido ainda, que o mesmo poderia ser devolvido pelo correio, por e-mail ou pessoalmente, neste último caso agendando-se uma data para que a pesquisadora pudesse recolhê-lo.

Em oito das dez escolas, o questionário foi entregue mais de uma vez, pois as equipes entraram em contato dizendo que haviam perdido o mesmo. Como as escolas de forma geral, após um semestre ainda não haviam dado retorno, a pesquisadora ligou (de uma a três vezes) para que as equipes técnicas informassem se havia alguma dificuldade e de que forma a pesquisadora poderia ajudar a resolvê-la. Ainda assim, apenas metade das escolas até o final de 2007 conseguiu entregá-lo, sendo duas delas por e-mail e as demais, pessoalmente. Um último questionário chegou via Coordenadoria para a escola 
onde a pesquisadora leciona em Julho de 2008, embora a data de preenchimento tenha sido de Julho de 2006. Esse percentual de 60\% de devolução, entretanto, superou a expectativa que era de $25 \%$ descrita na literatura para os usuários dessa técnica.

\section{Instrumentos de pesquisa:}

De acordo com MORGAN (1997), o grupo focal é uma técnica de pesquisa cujos dados colhidos a partir de interações grupais sobre um tema proposto pelo mediador, ocupa uma posição intermediária entre a observação participante e as entrevistas em profundidade. Trata-se assim, de uma entrevista em grupo e requer a presença de um animador/mediador, que segundo MINAYO (1994, p.129), “intervém, tentando focalizar e aprofundar a discussão”. Para IERVOLINO \& PELICIONI (1999), é uma técnica de pesquisa que utiliza sessões grupais, onde se torna possível a expressão das percepções, crenças, valores e atitudes sobre uma questão específica. Assim, as referidas autoras, salientam que a discussão durante as sessões fornece informações sobre o que as pessoas pensam ou sentem ou ainda, sobre a forma como agem. Pode ser considerada uma espécie de entrevista de grupo, embora não no sentido de ser um processo, onde se alternam perguntas do pesquisador e respostas dos participantes, pois consiste justamente na interação entre os participantes e o pesquisador, que objetiva colher dados a partir da discussão focada em tópicos específicos e diretivos.

O objetivo de análise é a interação dentro do grupo, uma vez que as idéias e colocações durante a discussão sofrem influências múltiplas dentro do grupo a partir dos comentários ou questões propostas pelo moderador/pesquisador. Os dados fundamentais produzidos por essa técnica são transcritos, acrescidos das anotações e reflexões do moderador/pesquisador e de outros observadores (PARASURAMAN, 1986).

As características gerais dos grupos focais, segundo KRUEGER (1994) são: envolvimento de pessoas; reuniões em série; homogeneidade dos participantes quanto 
aos aspectos de interesse da pesquisa; geração de dados; natureza qualitativa; discussão focada em um tópico que é determinado pelo propósito da pesquisa.

Outros autores, como RAMIREZ e col (1981), GLIK (1982) e BASCH (1987) afirmam que essa técnica enfatiza não apenas a compreensão dos problemas do ponto de vista dos grupos populacionais, como também o desvelamento das aspirações da comunidade a partir de sua própria voz, e que sua utilização é compatível com os princípios filosóficos da Educação em Saúde, já que privilegia a participação integral do educando no processo educativo.

Para CAPLAN (1990) e CALDER (1992), a entrevista individual e a observação dos participantes em grupos são duas importantes técnicas de coleta de dados qualitativos e o grupo focal como uma entrevista em grupo combina elementos dessas duas abordagens. Tem como vantagens, a coleta suficiente de dados dentro de um curto espaço de tempo, informações, que muitas vezes não seriam possíveis a partir de uma simples observação da realidade. ALBUQUERQUE (2006) acrescenta que entre as vantagens há o baixo custo, flexibilidade no formato e possibilidade de conciliação com outras técnicas, além de gerar no grupo sentimentos de emancipação e reciprocidade entre os participantes. Por outro lado, é preciso ressaltar que não oferece plena garantia sobre a espontaneidade de todas as respostas fornecidas por alguns participantes, que também podem estar sujeitos à dispersão, comum em grupos heterogêneos.

Como estratégia metodológica, a entrevista padronizada ou estruturada segundo LAKATOS (1991) "é aquela em que o entrevistador segue um roteiro previamente estabelecido; as perguntas feitas ao indivíduo são pré-determinadas. Ela se realiza de acordo com um formulário (....) elaborado e é efetuada de preferência com pessoas selecionadas de acordo com um plano". Para a autora a padronização é necessária para obter do entrevistados respostas às mesmas questões, de tal forma que permita uma comparação com o mesmo conjunto de perguntas, onde as diferenças reflitam apenas diferenças entre os respondentes e não entre as perguntas (Lodi, citado por LAKATOS 1991, p.197).

O questionário é um instrumento de rápida aplicação e de coleta de dados que conta com uma série ordenada de perguntas a serem respondidas por escrito e sem a presença 
do entrevistador (LAKATOS 1991). O envio, bem como a devolução do mesmo devese dar por meio de um portador ou via correio, cuja estimativa de retorno alcança cerca de $25 \%$. Por este motivo, Selltiz citado por LAKATOS (1991, p.201), afirma que é importante que seja claro e que a carta de apresentação que deve acompanhá-lo, seja escrita de forma atraente e fácil para facilitar o seu preenchimento. GIL (1994) avalia a importância desse instrumento dentro das pesquisas sociais, constituído por um conjunto mais ou menos longo de questões escritas dirigidas às pessoas com o objetivo de extrair suas opiniões, crenças, sentimentos, interesses, expectativas ou situações vivenciadas.

Os procedimentos metodológicos cumpriram as exigências éticas expressas na Resolução 196/1996 - CNS, sobre pesquisas científicas, utilizando-se do Termo de Consentimento Livre Esclarecido por escrito dos participantes, assegurando a privacidade anonimato e o direito de desistência da pesquisa a qualquer tempo, a confidencialidade dos dados coletados e a publicação dos resultados da pesquisa (ANEXOS). Para garantir o sigilo previsto no Termo de Consentimento Livre e Esclarecido assinado por todos os participantes desta pesquisa, os nomes dos mesmos, bem como das Unidades Escolares, convencionou-se que cada escola seria designada por uma das dez primeiras letras do alfabeto (A, B, C, D, E, F, G, H, I, J), e os membros dessas comunidades educativas entrevistados, indicados por números seguidos da letra respectiva de sua escola. Ex. A1, B2, J3. Nas escolas em que dois grupos participaram os entrevistados serão identificados como neste exemplo: C6I (integrante $\mathrm{n}^{\mathbf{0}} 6$, da Escola C, do grupo I de JEI) e C6II (integrante ${ }^{\circ}$ 6, da Escola C, do grupo II de JEI). 


\section{IV - ANÁLISE E DISCUSSÃO DOS RESULTADOS}

\section{1 - GRUPOS FOCAIS COM OS PROFESSORES:}

Um dos fatos que revelou o "efeito mobilizador" dos grupos focais ou, em alguns casos, "oxigenador" das discussões sobre as práticas das escolas é que, em metade delas foi solicitado à pesquisadora que retornasse para subsidiar projetos que os educadores passaram a desejar ou que já estavam em andamento, mas apresentavam dificuldades. Na verdade, essa parceria foi oferecida a todas as escolas, antes do início da pesquisa, devido à natureza da própria metodologia de pesquisa-ação e por sugestão da Secretaria Municipal da Educação ao autorizar a realização da mesma em suas escolas. Porém, apenas três delas colocaram à disposição dias e horários específicos para essa ação (Escolas B, E e I). Esta experiência será descrita posteriormente após a discussão e análise dos resultados dos grupos focais nas dez UEs, conforme apresentação a seguir:

\section{I - Dados levantados sobre a formação dos professores:}

a) - Cursos oferecidos pela Rede Municipal de Educação entre 2000 e 2005 (preferencialmente relacionados à EA):

De forma geral, os educadores afirmaram que já haviam passado por algum tipo de formação entre anos de 2000 e 2005, porém a maioria não tinha freqüentado cursos específicos sobre saúde ou meio ambiente, o que explica, em grande parte, a insegurança que muitos desses profissionais afirmaram ter para abordar esses assuntos durante suas aulas de forma mais aprofundada, dinâmica e transversal. 
b) - Avaliação dos professores sobre os cursos e opinião sobre a importância do seu oferecimento pela Rede:

A avaliação foi positiva para a maioria dos cursos freqüentados pelos professores e também houve consenso sobre a importância da Rede oferecê-los regularmente, mas ressaltaram que é preciso zelar pela qualidade dos mesmos, pela articulação teoriaprática e pelo acesso, que, segundo eles, deveriam ocorrer preferencialmente dentro dos horários coletivos de formação do professor (JEI) e no lócus escolar, sempre que possível.

C4 - (...) não é só importante para qualquer gestão de uma Rede fazer formação, como é uma obrigação. Faz parte da própria natureza, dentro de uma idéia de formação permanente. A questão não é essa... Eu acho que a questão é: Que tipo de formação se faz, não é? Tradicionalmente, as formações se fundam no cursismo, quer dizer, os profissionais saem das escolas e vão fazer cursos e essa formação tem sido concebida e realizada como formação principal e aí, do meu ponto de vista pessoal, é equivocada. (...).

O modelo "professor multiplicador" foi criticado, bem como o entendimento de alguns gestores municipais de que o período de formação e de execução prática são momentos divorciados e estanques e que, portanto, o aprendizado se dá de uma só vez:

C4 - A formação principal deveria ser a partir das práticas concretas existentes no interior das Unidades, e as outras serem formações articuladas a ela, porque dentro da idéia de multiplicação, alguém que vai e volta para multiplicar na escola, ela tem se mostrado falha ao longo do tempo... Desde a década de 50, nos primeiros processos formativos de professores, não tem surtido efeito, pelo simples motivo de que experiência não se multiplica... Você vive ou não vive.

A importância de os cursos considerarem as práticas das escolas, partindo destas para a reflexão sobre as teorias envolvidas em cada caso, apareceu como uma estratégia mais eficaz para atrair os educadores e tornar os cursos mais próximos da realidade e das necessidades das escolas. Ao que parece, concordam com FREIRE (2001; p.72) que a educação só pode melhorar se a formação permanente dos educadores se fundar "na prática que analisa a prática" e isso requer formadores altamente qualificados capazes 
de fazer os educadores pensarem em suas práticas e perceber nelas “(...) uma teoria não percebida ainda, pouco percebida ou já percebida mas pouco assumida".

C4 - E como os saberes em educação se constroem a partir das práticas, essas práticas têm que ser o ponto de partida, as práticas realmente existentes para qualquer tipo de formação em qualquer nível. Então a questão é: é obrigação fazer formação? Sim, mas que tipo de formação? Não pode ser qualquer formação. Pode-se oferecer um milhão de cursos e esses cursos não refletirem em nada na prática. Eles podem estar totalmente divorciados da prática.

Porém, as visões contraditórias de cada gestão em relação ao processo de formação do professor aparecem como um impedimento para a evolução dos conhecimentos do quadro docente, imerso anteriormente em um movimento de formação que foi interrompido sob a alegação de que esta não precisa ser contínua e permanente para melhorar a prática docente. São equívocos que se somam a cada nova gestão que insiste em começar do zero para anular erros passados, mas cometendo outros, como já relatou ZAGURY (2006). Mais grave ainda é creditar exclusivamente aos professores a responsabilidade pelo fracasso dos alunos, pois como também esta autora afirma, não é possível que uma legião de milhões de educadores sejam incompetentes ou relapsos, portanto, o erro só pode estar no sistema que escolhe estratégias e reformas educacionais que não conhecem e por isso não alcançam os problemas reais das salas de aula.

O depoimento a seguir confirma a desreponsabilização do poder público e o abandono dos professores à própria sorte em um cenário onde a formação contínua e permanente é condição imprescindível para a qualidade da ação pedagógica:

I5- (...) E mesmo assim, não vir com esses chavões: "Vocês já tiveram muitos cursos, agora tem que por em prática”. Eu acho que para o ser humano a aprendizagem é constante, não se aprende e acabou, ponto final. Não é assim! A vida toda é um ciclo, então quando se ouve esses chavões "Ah, na gestão passada teve muito curso, agora tem que por em prática e acabou! ora, (o professor vai ficar) só em sala de aula, gente! O professor precisa se alimentar e esse alimento é de conhecimento, é de arte, é de passeio é de tudo! Ele se alimenta essencialmente de tudo, de mundo, de informação... Eu acho isso fundamental. 
Essa fala também apresenta sintonia com a idéia de inconclusão do ser humano defendida por FREIRE (1996), que salienta a importância de nos percebermos como seres inacabados, abertos à procura, à descoberta e, portanto, sempre dispostos a aprender.

Da mesma forma, nas discussões apresentadas por SANTOMÉ (2001) sobre as novas demandas delegadas às escolas pelos governos e sobre a autonomia dos educadores, o referido autor salientou a importância de uma formação de qualidade, com atualização psicopedagógica e cultural, da disponibilidade de recursos econômicos e de condições de trabalho (espaço, materiais, parcerias, jornada de trabalho adequada) que impulsionariam a adoção de práticas mais inovadoras, no entanto, é possível dizer que esses elementos não estão presentes nos cenários estudados, pelo menos não de forma integral e integrada como deveriam.

Por outro lado, um pequeno grupo de entrevistados (observou-se neste caso que eram professores com muitos anos de trabalho, já próximos da aposentadoria e cujos depoimentos revelavam práticas tradicionais) minimizou a importância dos cursos de formação e justificou sua recusa em participar dos mesmos:

B5 - Bom, eu não tenho feito cursos, mas eu vejo que quando uma pessoa vai fazer um curso, não é para ela, ela vai para transmitir para os seus alunos, agora, eu não faço, porque justamente como foi dito, às vezes a pessoa vai fazer um curso e geralmente quem está dando, quer demonstrar que sabe mais do que a gente, às vezes na realidade, nem sabe o suficiente, então, eu pelo menos, dificilmente faço cursos, aliás, nunca fiz.

D3 - Eu nunca fiz nenhum curso da Prefeitura, não pretendo fazer e só não digo que tenho raiva de quem faz para não ofender aos colegas... Mas eu não faço até porque não acredito nesses tipos de cursos. E muita gente faz apenas para ganhar ponto. (...) como não fiz curso da Prefeitura, não posso dizer da Prefeitura. Em outros cursos que eu fiz, como professor, como diretor que fui no Estado, deixaram muito a desejar e perde-se muito tempo e no fim a escola não muda... Não muda, pelo contrário, complica-se ainda mais porque você não atende nem de um lado e nem de outro (...). 
Evidenciou-se um 'excesso de confiança' na própria bagagem intelectual, como se o conhecimento fosse estático, imutável e, portanto, não se renovasse ao longo do tempo. O professor B5, por exemplo, a poucos meses da aposentadoria confessou que jamais buscou atualização por meio de cursos. Demonstrou, por outro lado, 'desconfiança' na capacidade dos ministrantes, ainda que ele jamais tenha freqüentado cursos e embora essa visão tenha surgido claramente nesse depoimento em particular, esta é uma posição compartilhada por outros colegas do magistério. Por pertencer a esse meio profissional há mais de vinte anos, a pesquisadora tem observado que há uma 'fala comum' entre determinados grupos de educadores de que, os formadores provenientes da Academia estão distantes da realidade das escolas e por isso as teorias por eles defendidas, nem sempre têm significado real para o cotidiano vivido pelos educadores, daí a resistência de alguns em freqüentar cursos de formação.

Entretanto, esse comportamento também poderia ser analisado sob outro ângulo, tomando como base as observações de SANTOS NETO (2008; p.94). O referido autor acredita que a resistência às mudanças inerente a determinados grupos de pessoas, pode ocorrer devido ao conflito entre o 'novo' e o 'antigo'. Essas resistências podem ter origem na insegurança diante da novidade, mas também no "comodismo que se recusa ao esforço criativo", na dificuldade em confrontar novas opiniões, no pouco esclarecimento acerca do contexto no qual a vida se constrói ou então na forma crítica de encarar o processo que se apresenta.

A certeza de que "a escola não muda", pelo menos não para melhor, contribuiu para a posição declarada pelo professor D3, que já experimentou os dois lados do magistério: o de gestor (Diretor) e de professor. Para ele, ainda, os cursos geram transtornos por modificarem a rotina da escola, retirando os professores do seu exercício em sala de aula. Não reconhece, portanto, a necessidade e a importância da formação para os professores. Ao que tudo indica, prevaleceu a sua visão de gestor, preocupada com a administração e não com a eficiência pedagógica da escola, lembrando as discussões de SANTOMÉ (2001) sobre a figura do diretor, hoje travestido de manager, com uma mentalidade empresarial, em oposição às culturas de colaboração e responsabilidade coletiva e que, portanto, coaduna-se com a ideologia mercantilista. Assim, ao invés de defender a criação de meios para possibilitar a formação dos professores e ao mesmo tempo garantir as atividades pedagógicas para os alunos, há uma acomodação com o status quo - "a escola não muda mesmo" - e, dentro dessa ótica, 
com os docentes presos em suas salas de aula, garante-se, pelo menos, 'a ordem', independente do produto final, que é a qualidade do ensino. É uma posição que torna pertinente a observação de Oliveira no prefácio do livro Pedagogia da Autonomia (FREIRE 1996; p.11): "De nada adianta o discurso competente se a ação pedagógica é impermeável a mudanças". Da mesma forma, se houvesse a verdadeira autonomia da escola proposta por PARO (2001), com a participação de todos os segmentos da comunidade educativa na gestão administrativa e pedagógica, aumentaria o poder da escola no momento da busca por melhores condições de trabalho e de funcionamento junto ao poder público.

c) Possibilidade de aplicação dos conhecimentos adquiridos em sala de aula e dificultadores:

Quanto à aplicabilidade em sala de aula, a maioria dos professores declarou que é possível aplicar "quase tudo" o que se aprende nos cursos e os associam com uma oportunidade de "mudança" de visão e de prática:

H3 - Eu acho que é sempre válido, porque sempre traz alguma coisa e os que eu fiz, eram com pessoas realmente capacitadas, esclarecidas e assim foi bastante enriquecedor para o trabalho da gente diariamente. Muito bom.

I2 - Eu acho que os cursos em si foram muito importantes, até por questão de postura, de ver o mundo de uma forma diferente. Dá até para você mudar muita coisa em sala de aula, principalmente ligada à arte. Eu já não sou a mesma, eu mudei muito (...).

I3 - (...) Eu acho importantíssimo, a gente sempre coloca em prática, então a gente muda a forma de pensar, tem contato com outras pessoas, com outras formas de pensar e aí você começa a perceber que nem sempre a maneira como você trabalha é a mais correta. Eu aprendo muito com esses cursos e fico muito triste de não termos mais (nesta gestão).

Porém, no processo de aplicação, citam como principais dificultadores: o número excessivo de alunos por sala (superior a 25, número máximo recomendado pela 
UNESCO e fator considerado como um dos problemas mais graves da educação municipal na visão de especialistas como Paro citado em TAKAHASHI \& SANGIOVANNI (2008), ao distanciamento entre a teoria e a prática, a limitação do espaço físico para algumas atividades propostas nos cursos, a falta de materiais específicos ou a indisponibilidade dos mesmos (falta de acesso) dentro das escolas, o dilema de se desvincularem ou não dos conteúdos formais para trabalharem com outros mais atuais e relevantes, a falta de parcerias entre os colegas, coordenadores pedagógicos e/ou diretores (equipe técnica), o modelo de "professor-multiplicador" adotado pela maioria dos cursos, a falta de interesse dos alunos, a indisciplina e a ausência dos pais no processo educativos. Esses fatores desmotivam ou isolam o professor em suas práticas dentro da UE.

G1 - Eu acho também que um pouco de apoio falta. Porque às vezes a gente esbarra, até quer fazer as coisas, mas quando você precisa do outro, não sei, você encontra dificuldades. Você tem que saber que você vai ter que fazer tudo aquilo sozinho, você não encontra apoio da equipe técnica.

I3 - Eu vejo a falta de condições para a gente por em prática muita coisa que se aprende nesses cursos. Dependendo do curso, têm coisas que você aplica na sala de aula, mas eu vejo assim: a sala numerosa já é um complicador, a falta de material. (...) então, as condições são difíceis, e aí você acaba trabalhando sozinha, porque foi você quem fez o curso. Uma hora dá certo, outra hora não dá e você vai deixando a coisa também para trás, acaba perdendo aquilo que poderia ser algo bom, não é?"

\section{II - Quanto à educação e cidadania:}

a) - Papel do educador na educação atual:

Para os educadores existe uma distorção entre o que eles deveriam ser e o que eles são atualmente. Citaram características exigidas para o educador atual: artista, criativo, dinâmico, aberto, atualizado, polivalente, "milagreiro", disposto a fazer sacrifícios, "babá", assistente social, "pai/mãe". Houve ainda, depoimentos de professores que não aceitaram ser chamados de "educadores", pois consideravam esse termo demasiadamente amplo para a função que realmente desejavam desempenhar na escola, 
por isso o mesmo designava melhor as atribuições dos pais. Muitos declararam sentir-se sobrecarregados com tarefas que não reconheciam como suas ou para as quais não estavam preparados, como: atendimento psicológico dos alunos, auxiliares na vacinação, nos testes de acuidade visual, na verificação de cáries, febre, parasitas de pele e do couro cabeludo, administração de remédios, distribuição de leite, uniformes, kits escolares, entre outras. Discursos estes que encontram eco nas discussões apresentadas por SANTOMÉ (2001) e GASPARINI et al (2005), entre outros sobre as novas demandas que chegam às escolas pelas mãos do próprio poder público.

E5 - (...) Então, o professor hoje em dia, também não é um simples mediador do conhecimento, ele, muitas vezes, é assistente social, é pai, é mãe, é amigo da criança, psicólogo, dentista... Até extrai dente de criança! A gente tem que puxar 'dentinho mole' deles, então acho que esse papel está bem diversificado, bem amplo (...).

Para eles, são tarefas que lhes tomam tempo e atrapalham sobremaneira as atividades pedagógicas das quais são cobrados pela sociedade, estas sim, inerentes às suas áreas. No entanto, se para muitos, isso é um fator declaradamente negativo, para outros (a minoria entre os entrevistados), é uma forma de maior interação com o aluno e há aqueles, ainda, que não sabem dizer se isso é completamente positivo ou negativo, conforme revelam os depoimentos a seguir:

D1 - (...) a sociedade delegou para o professor as atribuições que até então o educador não tinha: (...) nos responsabilizarmos pela educação, pelo comportamental dessas crianças, como se fôssemos os pais. Além da carga de construir com essa criança o conhecimento dos conteúdos dos componentes curriculares, devemos ajudá-los na orientação sobre os problemas da sociedade contemporânea, enfim assumimos papéis, responsabilidades demais, eu não sei se são em demasia... Não sei também a quantidade de responsabilidades que temos que assumir, mas (a questão) é se estamos preparados para encarar essas responsabilidades... Portanto, a questão não é quantitativa, ela é qualitativa: no dia a dia a gente educa, a gente assume o papel de pai, o papel de mãe. Muitas vezes essas crianças enxergam no professor a figura masculina e na professora a figura de mãe, ainda mais aquelas de famílias desestruturadas, que é a realidade da escola pública (...) eles me olham como se esperassem de mim algo além... Eu sou uma referência, eu percebo nos olhinhos deles, eles me olham como pai! Muitas vezes, eu consigo me comunicar com eles, a maioria das vezes, aliás, com o olhar. Com meu olhar eles percebem se estou bravo, se estou alegre, se estou feliz, como se eu realmente estivesse convivendo com eles na casa deles. E isso, por um lado me motiva, me sensibiliza, por outro também me 
traz um ônus, um peso nas costas, que eu muitas vezes, não sei se estou preparado para enfrentar...

O educador descrito por PERRENOUD (2000) que, mesmo não estando preparado para enfrentar as adversidades que surgem no caminho, não renuncia à sua função e 'rema contra a maré', porque acima de tudo, sabe o que quer e para onde deve ir, se confronta com a postura daquele que foi descrito por GADOTTI \& FREIRE (2001) como reacionário. Este último exprime de forma veemente o seu desapontamento com aquilo que considera degradante no exercício da profissão e no atual quadro educacional, mas ao mesmo tempo, assume publicamente a sua desistência como agente de transformação:

D3 - Boa pergunta! Boa pergunta! O problema ganha mais dimensão a partir do momento em que nos colocamos como educadores, porque eu não sou educador, eu sou professor de língua portuguesa (...) então hoje, o professor, ele não é professor, ele é educador realmente, mas no sentido reles da palavra, o mais simples, do tipo: "olha, fecha a porta! Peça licença!, não cuspa no chão! Não mastigue chiclete, não ponha boné! Seja educado!”, entendeu? Estamos ficando longe disso. Aliás, eu acho que a escola deixou de ser escola já há muito tempo e é por isso que os pais, a comunidade já não considera nem respeita mais escola como tal, porque ela perdeu o seu princípio básico que é realmente $o$ de ensinar e por que não? De transmitir conhecimentos, sim! Desde que disseram que o professor não é mais o detentor do conhecimento, o professor deixou de estudar, porque ele não precisa mais deter (o conhecimento), ele tem que ensinar... Ensinar o quê? (...)

Considerando-se as reflexões de ANTELO (2004), não estar preparado para esta ou aquela realidade é um processo natural na educação, já que "o tempo presente não dura, estar preparado para o futuro é astrologia e para o passado, tango". Para ele, o ato de educar “(...) implica enfrentar situações mais ou menos adversas, de desamparo ou cuidado, mas sempre um tanto desconhecidas". Referindo-se ao pensamento filosófico, afirma que as relações pedagógicas só são possíveis quando o 'incalculável' surge, já que não somos robôs programados para esta ou aquela realidade. Nesse sentido, a falta de preparação para a adversidade é inerente ao ato educativo e reconhecer isso torna nossa tarefa de educar um desafio enorme. Não se pode negar a novidade, quando se tem a pretensão de educar, pensando numa educação que vai além da transmissão do conhecimento, que visa à transformação do outro. 
Esses aspectos, ainda muito "embaçados" na lógica dos professores, desencadearam uma discussão acalorada em alguns grupos (nitidamente perceptíveis nos depoimentos D1 e D2), aflorando as concepções divergentes de educação e da imagem que os professores têm de si mesmos, conforme foi discutido em SANTOS NETO (2004a) acerca da construção da concepção pedagógica do professor. Tais olhares diferenciados produzem no ambiente escolar, inúmeras situações de conflito entre os próprios docentes, entre estes e seus alunos e também com os pais. Além disso, influenciam na maneira como as políticas educacionais que chegam às escolas, serão recebidas e desenvolvidas. Conforme já discutido, nesse cenário é possível identificar os dois tipos de educadores citados por GADOTTI e FREIRE (2001): o reacionário, que prefere deter o poder do conhecimento e o revolucionário, que opta por compartilhá-lo com o aluno, mostrando dois rumos opostos, também ilustrados por PERRENOUD (2000) e SANCHO (2006) na introdução desse trabalho.

A partir dos depoimentos dos professores D1 e D2 abaixo, observa-se que muitos ainda estão distantes da definição de educador dada por SANTOS NETO (2004; p.2): “(...) é pois, aquele que estando constituindo-se a si mesmo como sujeito se dispõe a auxiliar o outro, o educando, na construção de dele mesmo" e do raciocínio de FREIRE (1996; p.36-37), quando afirma que ensinar exige estética e ética e não pode se reduzir a um ato de transferência de conteúdos técnicos, porque isso seria “(...) amesquinhar o que há de fundamentalmente humano no exercício educativo: o seu caráter formador" e portanto, de nada adianta o ensino dos conteúdos sem a formação moral do educando - isto seria desrespeitar a sua natureza humana.

D1 -(...) tem professor que ainda vê o aluno como antagonista. O aluno não é antagonista! E tem professor que ainda está muito preso à roupagem do professor e pouco entende o que é ser educador, quer dizer, ainda é mais professor do que educador!

D2 - Não sou educadora mesmo! Eu não sou educadora e não quero ser educadora e ponto final! Ora, que coisa!

F8 - (...) eu acho que o educador é também um símbolo positivo para os alunos, apesar de tudo isso que nós somos, mas a gente vê que os alunos se inspiram nos professores ainda, sorte nossa, não é?(...) e isso que é importante, apesar de tudo estar contra nós, talvez seja a única coisa que eles têm. Eles não têm família, o referencial, então nosso papel é muito importante. 
Em algumas falas, como a do $\mathrm{F} 8$, os professores retratam a situação de desvalorização da profissão: “(...) apesar de tudo estar contra nós” e que reflete na auto-estima dos mesmos: “(...) apesar de tudo isso que nós somos (...) sorte nossa, não é?"

Outras também refletem o resultado das "políticas educacionais vacilantes", que ora propõem uma volta ao passado (quando, para esses governantes e para a sociedade, os alunos aprendiam realmente), ora implantam novas metodologias com as quais, nem sempre os professores e, por vezes, os pais, estão familiarizados, por falta de uma formação adequada ou porque antes que elas fossem completamente assimiladas, trocaram-se os governos e com eles, outras políticas vieram. Nesse contexto de incertezas e de ações que se anulam constantemente, que gera frustrações em uma parte dos professores e a 'busca pela utopia em outra', há professores que ainda acreditam que está somente em suas mãos (e não do governo, criador das 'políticas vacilantes' ou da sociedade, demandatária das políticas) o poder de "resolver esse dilema" conforme a fala seguinte:

C7 - A função do educador na escola atual é criar a escola atual, porque o que nós temos é "um bicho esquisito", então ela tenta ser a escola antiga, ou ela tenta ser uma escola nova, diferente, e ninguém se encontra nessas práticas diferentes, todos ficam estranhando e se estranhando, então é um ir e vir, mas a situação hoje é uma situação vacilante, para trás e para frente e a função do educador é resolver esse dilema aí, nesse momento.

b) - Perfil dos alunos que os educadores desejam formar:

Apesar das controvérsias sobre os meios mais eficazes, a maioria dos professores descreveu um perfil semelhante em relação aos alunos que pretendiam formar: "alunos conscientes, críticos, participativos, autônomos, protagonistas, responsáveis, felizes" aproximando-se do que BARBOSA (1998) definiu como 'autorcidadão':

E5 - Não sei se é utopia, mas nós desejamos formar um aluno criativo, que seja também leitor, que saiba ler entre as linhas e que seja cidadão, que saiba 
reconhecer os seus direitos, os seus deveres na sociedade, que pratique a cidadania. Não sei se é sonho, mas é isso que a gente mais deseja!

H4 - Crítico, consciente, responsável, feliz... Está bom pra gente...

Reconhecem a dificuldade dessa "missão", devido à própria estrutura organizacional da escola, que, na opinião de alguns, "engessa" o professor e o aluno e, conseqüentemente, o processo de ensino-aprendizagem.

Observou-se na falas desses professores, aquela frustração pelo desejo que precisa existir, mas que ao mesmo tempo, já se sabe que não poderá ser realizado dentro daquele contexto, o que remete às considerações de SANTOS NETO (2004) acerca dos educadores atuais, que submetidos à condições tão precárias de trabalho, encontram-se exauridos em suas forças e acabam muitas vezes, sucumbindo diante da ideologia neoliberal que prega a estagnação do indivíduo frente à necessidade de mudança e transformação do mundo:

C4 - Acho que a gente poderia começar pelo clichê: o aluno crítico, participativo, solidário, exercendo sua plena cidadania (risos do grupo). Mas aí, a questão é a seguinte: os clichês colocados neste contexto que a gente vive, são para não acontecer. Por outro lado, é o que a gente quer mesmo. Mas nessa organização (da educação), a gente não vai conseguir. Então, me parece que é um clichê bastante irônico, porque nessa idéia, afirma se negando (...)

C5 - (...) O que está acontecendo é que o papel do aluno está diretamente relacionado ao nosso, é difícil você falar de um sem falar do outro, um referencia o outro, então o que está acontecendo com o educador reflete no educando e vice-versa.

c) - Eficiência da escola em trabalhar com temas importantes: sustentabilidade ambiental, violência, corrupção, democracia participativa:

Entretanto, na opinião dos mesmos, a escola não dá conta de trabalhar esses aspectos da cidadania, embora tente "falar um pouco" no dia-a-dia, sobre os grandes temas propostos (sustentabilidade ambiental, violência, democracia), mas não de forma sistemática, planejada. Isso ocorre, principalmente quando surgem oportunidades, tais 
como a ocorrência de fatos de grande impacto na escola ou na sociedade, neste último caso veiculado pela mídia a qual os alunos também têm acesso. Mas essas "falas" (que raramente se transformam em ações) não são planejadas e realizadas de forma intencional mesmo quando estão previstas no Projeto Político Pedagógico (PPP) da escola, ou seja, são isoladas, desarticuladas dentro das áreas de conhecimento e ficam relegadas a um segundo plano dentro do currículo, portanto, semelhante ao que afirmou o professor $\mathrm{C} 4$, sobre o perfil do aluno que se deseja formar, a prática pedagógica real dentro das Unidades Escolares, "nega" aquilo que ela mesma "afirma" desejar realizar nos seus educandos.

Parte dos professores "assume a culpa" justificada pelo comodismo, pelo excesso de demandas, pela priorização dos conteúdos formais, ou pelo despreparo para lidar com essas questões.

I3 - Eu acho que algumas coisas a gente tenta, outras, a gente ignora... É mais cômodo! Nos não estamos dando conta nem das coisas básicas, quanto mais da questão ambiental (...)

I2 - Eu acho que ainda tem muitas pessoas que estão preocupadas só em seguir um currículo que não é feito por nós, que não tem as mesmas características da comunidade que a gente trabalha. $O$ pessoal fica preocupado em passar conteúdo e esquece esse outro lado... Então quando você fala de educação ambiental, de combate à violência, do reforço da cidadania, a gente precisaria estar modificando o currículo da escola para atender esse outro lado, que é muito importante nos dias de hoje, que a gente acaba deixando sempre para depois e o depois nunca chega porque a gente tem essas demandas todas para cumprir, é isso!

Nesse depoimento observa-se o desconhecimento dos professores sobre o que foi discutido anteriormente em SILVA (1996), acerca do currículo e do poder e sobre a importância do posicionamento firme do educador contra tudo aquilo que se opõe à construção de um currículo emancipatório, imprescindível para a formação dos alunos que, a tomar como base seus discursos, eles próprios idealizam. Também revela a incoerência e a inconsistência do discurso e da prática docente explicadas por SANTOS NETO (2004a) em função da ausência de uma reflexão filosófica que permitiria aos educadores problematizarem seu próprio pensamento e a partir daí, superar uma forma de ingenuidade, que, segundo o autor, alimenta a dissonância entre o pensar e o agir. 
B3 - Eu acredito que a escola não responde a essas questões. Eu noto que nas escolas onde eu passei, esses temas são muito pouco discutidos e quando o são, isto se dá através de um projeto que tem começo, meio e fim, não tem continuação... Eu acredito que os alunos pouco vêem, por exemplo: problemas ambientais - eles até conhecem, mas não conseguem imaginar o que pode ser feito para mudar isso, ou como pode ser feito... E mesmo assim, esse assunto fica focado em uma ou outra disciplina e as demais não trabalham, por isso fica muito vago e eles acabam saindo da escola sem nem ao menos saber que questões são essas...

Outros encontram outras causas, como a falta de investimento na formação política, na qualidade de vida e na autonomia do professor, além dos pais, que não fazem a sua parte nessa formação; da mídia, que influencia negativamente e da própria sociedade, que vive e reproduz valores controversos.

C6I - Olha, a gente já falou aqui da manutenção da qualidade de vida do professor para que se dê conta de tudo isso (...). Há que se investir no discurso político e numa formação política, porque, justamente com esse empobrecimento, essa proletarização do corpo docente você teve o esvaziamento desse discurso e isso reflete diretamente na prática do professor dentro da sala de aula. A escola falida (...) uma instituição que não se renova. $O$ professor não tem um discurso político claro, embora carregue todas as teorias diluídas na sua atividade diária, na sua visão de mundo. Mas tudo isso junto, acho que cria uma condição desfavorável para que se tenha todos esses itens atendidos.

E7II - Não dá, porque cada vez mais se afasta do papel que é o da escola: fica muito assistencialista, fica muito cheia de tantas coisas e não se cumpre o papel que é dela. (...) começa pelo número de alunos dentro de uma sala de aula, você não consegue fazer uma roda com 35 alunos (...) para poder criar um ambiente de debate, de reflexão. Para poder sair da escola para a calçada você enfrenta não só os muros da escola, mas o muro da direção, o muro do sistema, o muro da coordenação (pedagógica), o muro dos pais, você não pode levar ele daqui para a praça, então quer aprender como? Dentro de quatro paredes você consegue desenvolver essa criticidade quanto ao meio ambiente, quanto às questões fundamentais da nossa atualidade? Você não consegue porque você também trabalha em três, quatro escolas... Então tudo isso é um dominó.

F6 - Não, porque nem a própria sociedade dá conta de si mesma com tantos exemplos antiéticos.

E6II - Outro agravante que eu vejo é o seguinte: nós aqui na escola podemos até tentar, (...) mas eles estão vendo na TV a própria concepção na política, tudo isso aí, uma coisa que eles apregoam, mas também não fazem. (...) Está 
difícil até para o jovem, para nós educadores estarmos sabendo o que é certo, o que é errado, se eles só estão assistindo coisas erradas (....).

E3 - (...) Os pais tinham que ter esse papel em casa e nós aqui na escola estaríamos complementando, ou seja, o contrário. (...) Só que hoje você não pode contar com ela - esqueça a família.

De forma geral os professores consideraram que a responsabilidade pela descontinuidade dos projetos na escola é, em primeiro lugar do poder público, em função da alternância de partidos políticos. Segundo eles, cada governo tem projetos próprios e não leva em consideração o que foi desenvolvido na administração anterior. As prioridades escolhidas pela própria escola em relação ao seu currículo são ainda menos valorizadas e deste modo, o poder público às vezes age de forma arbitrária e irresponsável. Em segundo lugar, apareceu o rodízio constante de professores na Rede, que interrompe e desmobiliza o trabalho coletivo. Em terceiro lugar, os projetos individuais, desvinculados do Projeto Político Pedagógico (PPP); Em quarto, os problemas estruturais na escola e em quinto lugar, a falta de envolvimento de alunos e de outros segmentos da comunidade educativa.

B- Desânimo dos professores por excesso de trabalho, falta de parcerias, falta de retorno, falta de coletivo, troca da administração municipal.

C-Porque são projetos individuais desvinculados do PPP, porque são projetos de governo, quando saem, acabam; faltam subsídios, formação para os professores que tire das individualidades, despersonalize os projetos; não entram no currículo; dependem de ações de governo, principalmente;

D - Remoções docentes, enfraquecimento do grupo, desarticulação, mudanças políticas, vício de interromper politicamente os projetos.

Com relação ao PPP, citado nos depoimentos da escola C, é importante recorrer ao que foi discutido anteriormente sobre a construção do mesmo e sobre sua relação com o plano de trabalho do professor, que deve ser elaborado sem perder de vista os objetivos e diretrizes do PPP. Por isso, esse documento deve estar à disposição de todos os educadores para que dele façam uso, sempre que necessário, a fim de não se afastarem dos seus horizontes traçados coletiva e democraticamente. 


\section{III - Com relação à Educação ambiental na escola:}

a) - Existência de atividades ou projetos de educação ambiental e inserção destes no projeto político-pedagógico (PPP):

Para grande parte dos educadores, o PPP é um documento inacessível, desconhecido. Na maioria das escolas, nem mesmo a pesquisadora teve acesso a ele, embora o tivesse solicitado durante as visitas às UEs. Nesses casos as equipes técnicas geralmente alegavam que o mesmo encontrava-se em processo de re-organização, ou de análise nas Coordenadorias de Educação. Por isso, nessa pesquisa, as informações obtidas sobre o mesmo, basearam-se nos discursos dos educadores participantes. Entretanto, em algumas U.E.s os professores afirmaram enfaticamente que não só o conheciam como tinham certeza de que essas questões estavam inseridas nele, citando inclusive projetos e ações em andamento, relacionados ao meio ambiente e à cidadania.

D1 - A minha resposta pode te deixar chocada: eu nunca li o PPP. Estou aqui há três ou quatro anos e nunca tive acesso ao PPP. (...) há um, dois anos atrás, eu vi 'o tal' do PPP: um calhamaço de folhas, não sei se escritas ou digitadas, ao longe, na mesa da Coordenadora Pedagógica, era isso que eu queria dizer...

F5 - A nossa Coordenadora Pedagógica sempre nos orienta com o PPP. Ela fala que nós temos os projetos no PPP e que ele está à disposição para quem quiser olhar. Ela sempre nos deu carta branca nesse aspecto. E nos consulta também sobre o que vai ser colocado nele.

I3 - Na verdade o PPP desse ano é uma continuidade do ano passado, então nós temos três PEAs (Projetos Especiais de Ação): um que é Ler e Escrever, por imposição (da Secretaria), outro que é São Paulo é uma Escola, por imposição (da Secretaria) e o nosso escolhido é Vida em Sociedade, que vem pensando nessas questões de violência, nas questões atitudinais, de comportamento, sim!

b) - Estratégias utilizadas para desenvolver os projetos e ações: 
Quanto às estratégias utilizadas para desenvolver os projetos e ações, a maioria dos professores utiliza a "conversa informal" com os alunos quando surgem oportunidades; poucos desenvolvem projetos. Assim, contrariam os princípios da EA, que não se baseiam na simples transferência de informações (sobretudo por meio de 'conversas informais'), pois estas informações podem ser encontradas em diferentes meios e não apenas na escola e além disso, não garantem que os conhecimentos e valores imprescindíveis para a tomada de decisões em prol da resolução dos problemas socioambientais sejam incorporados pelos educandos.

C6 - As ações são pontuais, como disse C1, porque elas não são articuladas (...), elas acontecem na medida em que nós falamos, tentamos nos atualizar e atualizá-los também. Então, elas vão acontecendo dessa maneira empobrecida, mas é o que nós conseguimos alcançar...

D1 - O conteúdo expositivo tradicional, giz, lousa e as ferramentas disponíveis: mapas, cartazes, revistas, músicas, utilizamos muito aqui a linguagem do cinema, na sala de vídeo, o laboratório de informática, até o ano passado... Este ano naufragou a sala de leitura e a sala de informática. (*)

(*) Naquele momento (2006), as aulas de informática educativa e de leitura haviam sido suprimidas do horário de aulas dos alunos, em função do projeto 'São Paulo é uma Escola', da Secretaria Municipal de Educação, que exigia que essas aulas fossem oferecidas apenas como atividades extraclasses para os alunos que tivessem condições de permanecer fora do horário de aulas. Houve um grande prejuízo para a Rede, já que os projetos das diversas disciplinas que utilizavam essas ferramentas para desenvolver um trabalho articulado, foram sacrificados e depois de forte pressão dos educadores a SME revogou a decisão e elas retornaram à grade curricular novamente).

Há professores que não acreditam na eficácia dos projetos e das "conversas" para alcançar mudanças de atitudes nos alunos:

J3 - Por mais que a gente fale de meio ambiente, dos cuidados, da poluição, eles saem e deixam o papel no chão... Então parece que a gente fala e eles participam da aula, eles sabem o que faz poluir o ambiente, mas a ação, isso não acontece... 
D3 - Caímos também na mesma estória, que o D1 falou: acaba sendo um trabalho de um ou de outro professor, bem isolado, ou então quando há um projeto como no ano passado houve, que foi da professora “ $X$ ” , (...) agora o que me parece é que depois na prática (...) o cara joga papel no chão (...) não se internaliza, faz-se mil projetos, mas as idéias que esses projetos passam não se internalizam.Eu trabalhei na escola particular e é a mesma coisa! (...)

Nesse último depoimento, surge novamente a personalização dos projetos e ações - "O projeto da professora X" - os próprios colegas professores permitem que isso ocorra em detrimento do trabalho coletivo, o qual certamente, seria mais interessante para convencer o aluno da importância da aquisição de tais valores, mostrando a coesão do grupo no desempenho da missão da escola e a natureza interdisciplinar da própria EA.

Contudo, há também aqueles que defendem a idéia de que as mudanças de atitudes levam tempo, por isso as estratégias nem sempre são falhas, cumprem seu papel em longo prazo. O professor D1 usa como argumento sua própria experiência de vida:

D1 - Eu não sei se o que eu vou falar é uma grande besteira, mas (...) quando eu era criança, com uma idade aí desses meninos de $6^{a}, 5^{a}$ série, eu me lembro que eu batia muito no meu irmão, falava palavrão e apanhava de minha mãe, (...) e eu passei anos na minha infância, batendo no meu irmão, falando palavrão e apanhando da minha mãe, ou seja, durante esse processo todo, de alguma forma eu não internalizei, mas teve um momento que eu o fiz. Então, vamos tentar pensar o seguinte: eu estou dando um exemplo que eu estou construindo da minha realidade. (...) Você faz um projeto com os alunos sobre meio ambiente e como o D3 coloca, no momento seguinte o aluno joga papel no chão. É lógico que internalizar certos conceitos, certas práticas, valores, eu vejo sob a perspectiva de longa duração, eu não vejo como algo que se dá imediatamente. É um trabalho de longo prazo (...) então hoje, a criança joga papel no chão, na $5^{a}$ (...) na $7^{a}$ (...), vai ter um momento em que ela vai internalizar o que lhe foi ensinado, por conta do que a escola trabalha, a família trabalha. Se a família não trabalha, a escola trabalha. (...) alguns internalizam mais rapidamente, (para) outros é realmente uma perspectiva de longa duração. A educação se faz ao longo da vida inteira, não é numa $5^{a}$, numa $6^{a}$ ou numa $7^{a}$ série que estas questões serão resolvidas. É ao longo da vida.

No caso das cinco escolas que desenvolvem projetos de educação ambiental, essa "conversa" aparece conjugada com outras estratégias (estudos da realidade local, jogos pedagógicos, campanhas de conscientização, horta, reciclagem, organização de conferências, seminários, exposição de trabalhos, projetos com o grêmio estudantil e 
outras formas de associação de alunos), mas nem todas dão continuidade a essas ações nos anos subseqüentes. Ademais, constituem mais um conjunto de atividades de educação ambiental do que um processo de educação ambiental, que implica em formação política sistemática e de longa duração.

H2 - Dentro do projeto da escola, na questão ambiental a gente andou fazendo algumas atividades práticas, como mutirão de limpeza, conscientização quanto à situação dos lixões próximos às residências (...), mas nada além do que é possível para nós aqui dentro...

F7 - Olha, essas questões de ecologia, meio ambiente e de atualidades, a questão da violência e tudo, nós trabalhamos em textos dentro do projeto Ler e Escrever, nós trabalhamos com filmes e as próprias conferências (infantojuvenis do meio ambiente) nós usamos. Na verdade, os alunos fizeram apresentações com todos os recursos que haviam na escola: a informática e o data-show, usando o som e a rádio da escola. Então todos esses recursos foram usados (...).

E1 - Eu, como auxiliar de período, tenho um trabalho desenvolvido na área de Educação Física, onde apoiei o xadrez e o meio ambiente. (xadrez-ambiental). Essa é uma estratégia, uma vez que os alunos gostam do xadrez e também se interessam pela vida do ambientalista Chico Mendes (...) o nome do projeto é "Chico Mendes e os Benfeitores da Natureza" (...)*

*Esse projeto teve apoio do SESC-Itaquera, por meio do setor de Gestão Ambiental, que ofereceu formação para os professores (2001 a 2004) de diversas escolas da região leste, numa parceria com a Coordenadoria de Educação de Itaquera. Além da formação, a equipe do SESC acompanhava a implantação desses projetos nas UEs.

c) - Existência de uma Agenda 21 Escolar e seu processo de construção:

A Agenda 21 parecia ser um documento desconhecido para a maioria dos professores, apesar de seis das dez escolas terem tido contato com esse documento durante os anos de 2003 e 2004, nos processos de formação dos Projetos Ler e Escrever e Mão-na-Massa, na Coordenadoria de Educação de Itaquera e que envolveram representantes do corpo docente e equipes técnicas. A rotatividade desses profissionais nas escolas, a falta de articulação entre eles dentro das UEs ou mesmo a interrupção, 
nos anos subseqüentes, desse modelo formativo que procura integrar os conteúdos e projetos já existentes na Rede, poderiam explicar o não reconhecimento imediato desse trabalho em anos anteriores. Tanto é que, após nova explanação da pesquisadora, metade das escolas, por meio de alguns professores, disse que havia começado a elaborar a Agenda 21 escolar, mas que a mesma estava sendo construída somente pelos professores, sem envolver os alunos ou o restante a comunidade escolar.

J4 - A gente não chegou a discutir para organizar. A gente precisava de subsídios, de leituras, para gente poder se articular com propriedade, não é?

J5 - Precisamos de apoio.

E3 - De certa forma nós já temos uma Agenda 21, porque há um trabalho previsto para cuidar de uma praça que a escola adotou, então na prática nós já temos uma Agenda 21. Ela foi escrita, eu não tenho aqui, mas foi escrita sim. Ela foi construída com o grupo de professores, foi discutida e no nosso PPP também consta uma preocupação e uma das propostas é trabalhar a participação cidadã para melhorar o meio ambiente.(...)

H4 - Ah, a gente sabe que é do meio ambiente, mas a gente não organizou nada não.

H1 - Nunca ouvi falar.

Mais uma vez, os projetos que vêm da Administração como prioritários, são vistos pela Escola como impedimento para o desenvolvimento de outras ações, quando na realidade, se houvesse a compreensão por parte da escola e da própria Administração de que os projetos representam a somatória de esforços no sentido de melhorar o desempenho da escola, o currículo poderia ser reorganizado para atender às múltiplas necessidades inerentes ao processo educacional dentro da realidade de cada UE:

F2 - Bom, nós pensamos sim em elaborar a Agenda 21 dando continuidade à segunda Conferência do Meio Ambiente, que seria este ano, mas por enquanto está tudo parado... (...) é porque não é o projeto principal da escola... O projeto principal da escola é o Ler e Escrever... É o da Administração atual (20052008). 
Algumas escolas inclusive demonstraram conhecer esse caminho, onde todos os projetos estão articulados dentro do PPP e assim, os professores conseguem fazer a ponte entre eles durante suas aulas:

E4 - Quanto ao meio ambiente a gente trabalha bastante os arredores da escola, o bairro, a cidade (...). Particularmente, na $2^{a}$ série, a gente contou a estória "O pequeno pode tudo", e a partir da estória eles desenvolveram cartazes com as quatro partes da estória: a cidade, o meio urbano, a floresta nativa, o deserto e a floresta que o pardalzinho plantou. Foi muito interessante porque as crianças tiveram a oportunidade de vivenciar esses quatro tipos de ambiente e depois eles produziram em cima disso. Agora essa semana nós vamos fazer a reescrita e a gente trabalha toda a ortografia, pontuação em cima da estória...

d) - Percepção dos educadores acerca da saúde ambiental das escolas:

Em apenas três, das dez escolas, os educadores consideraram o seu ambiente escolar saudável. Os demais atribuíram à falta de estrutura física adequada, ao excesso de barulho (poluição sonora), poluição visual, ambiente "sujo", prédios mal conservados, animais transmissores de doenças ou aos problemas nas relações interpessoais, como fatores degradantes da saúde ambiental das escolas. Neste caso, os motivos relacionais se sobressaíram em relação aos demais, considerando o número de respostas dadas e entre eles, figuraram: falta de harmonia, de democracia, de respeito e muita tensão emocional, o que, segundo alguns, eram fatores que afetavam significativamente o seu desempenho profissional e a sua saúde, como indicam pesquisas acerca das principais causas de afastamento desses profissionais de escolas públicas, onde a depressão e outros problemas emocionais ocupam os primeiros lugares (GASPARINI e col., 2005; p.191). Para esses autores, "embora o sucesso da educação dependa do perfil do professor, a administração escolar não fornece os meios pedagógicos necessários à realização das tarefas, cada vez mais complexas", o que pode ser evidenciado nos depoimentos colhidos em cada uma das escolas, ao serem perguntados se consideravam seu ambiente escolar saudável:

ESCOLA A - NÃO: muito barulho, sem estrutura, falta de professores, alunos com problemas sociais, solidão dos professores para resolver esses problemas, impotência; 
ESCOLA B - NÃO nesse momento: desrespeito entre as pessoas, conflito, violência, impunidade, falta de cooperação da família dos alunos, solidão no trabalho pedagógico cotidiano, falta de apoio, não vê frutos no trabalho, falta cumplicidade entre os professores, falta dedicação de professores $e$ comunidade, desânimo para trabalhar, falta perspectiva, sobrecarga (com o projeto de SME que implantou a pré e pós-aula). SIM: porque são casos de indisciplina isolados.

ESCOLA C - Ainda NÃO: falta organização sistêmica, falta identidade, um currículo para unificar ações, existem apenas momentos saudáveis que dão a sensação de ambiente saudável (ambiente humano);

ESCOLA D - NÃO: falta tudo o que dissemos sobre ambiente saudável, não tem organização, tem tensões, falta compromisso (não de todos), não há objetivo comum;

ESCOLA H - NÃO: poluição visual, pombas, sujeira, "um inferno”, horários corridos, tumulto nos horários (com o projeto da SME de pré e pós-aula), falta professores, espaço dos professores é inadequado: o local das refeições, os banheiros e a sala de estudos se reduz ao mesmo espaço; estacionamento pequeno (tumulto e preocupação com o horário de entrada e saída dos carros); falta de segurança; sala de professores é depósito de materiais diversos.

ESCOLA I - NÃO: excesso de barulho, acústica ruim, indisciplina, pichação, depredação do prédio, falta de perspectiva, projetos estão no papel, não há trabalho coletivo, estresse emocional (relacional ruim)

ESCOLA J - NÃO é o ideal: falta integração, falta harmonia profissional, falta organização profissional.

ESCOLA E - SIM: tem um clima bom, a escola é bonita, todos se conhecem, se tratam bem e tem união;

ESCOLA F - SIM, muito saudável: espaço físico. MAIS OU MENOS: barulho em excesso e agressividade entre os alunos;

ESCOLA G - SIM: saudável em relação aos professores (gostam de vir para a escola) e sentem-se bem apesar dos ratos; 
Tomando como referência as percepções dos professores quanto à saudabilidade do ambiente escolar e a julgar pelas observações feitas também pela própria pesquisadora durante as visitas nas escolas, os fatores acima relacionados estão realmente presentes e a combinação destes, em cada situação torna o convívio diário desses profissionais com estas condições, um verdadeiro sacrifício, configurando-se em um desafio, para aqueles que ainda acreditam na reversão do quadro ou em frustração, desânimo e não raramente, em doenças para outros que assumem um estado de impotência e apatia.

As autoridades públicas e de modo especial, a Secretaria Municipal de Educação, no entanto, não têm dado a devida atenção à saúde ambiental das Unidades Escolares, como se esse fator pudesse ser destacado ou ter sua relação minimizada dentro do ambiente e das interações geradas pelo processo educacional que envolve profissionais, alunos e pais. É importante ressaltar que projetos como o da "Escola Promotora de Saúde - EPS" não foram sequer citados pelas Unidades em referência nesse trabalho, indicando que essas iniciativas governamentais também são pontuais na Rede e não têm tido o alcance necessário para promover a transformação desses cenários de degradação do ambiente físico e psicossocial, neste caso, causador dos problemas descritos pelos educadores.

Além disso, tais iniciativas parecem estar descompensadas, no sentido de privilegiar a identificação e resolução de problemas que afetam a saúde e a qualidade de vida de um determinado segmento da comunidade (alunos, por exemplo) em detrimento de outros, o que é certamente um equívoco, em se tratando das proposições da OMS para as EPS, que consideram importante a promoção da saúde entre todos os segmentos e uma visão de saúde que perceba a integração entre os aspectos físicos, psíquicos, sócio-culturais e ambientais. 


\section{IV - Quanto à participação dos educadores nos sindicatos e em outras esferas de participação política e social:}

As formas de participação citadas pelos educadores nos sindicatos da categoria foram: como representantes de escola (alguns); acompanhamento dos jornais dos sindicatos (a maioria); participando das assembléias em períodos de greve (a maioria); participando de passeios, viagens, festas, congressos (uma pequena parte). Apenas dois declararam não participar de nenhuma atividade sindical e a maioria afirmou estar descontente com a atuação dos dirigentes do principal sindicato da categoria. Embora ocasionalmente também sejam oferecidos cursos, nenhum professor declarou ter participado de algum deles, o que poderia demonstrar neste caso, que essa não é, na visão dos professores, uma missão destacada dentro desse tipo de instituição:

D1 - Participo através de correspondência, quando enviam aspectos relativos à minha evolução funcional.

D2 - (...) leio os jornaizinhos que me mandam (...)

C6I - Eu, desde que entrei na Prefeitura em 95, fui representante, fui conselheira (...), fui da diretoria (...) a gente participava ativamente, tinha uma mudança real e concreta dentro do sindicato. Tínhamos várias inserções e discussões em várias regiões da Cidade com relação ao papel do movimento sindical. Hoje, nós temos 18 entidades! (...) eu acho que a crise que nós temos (...) é uma crise nacional, (...) do movimento sindical, porque hoje o movimento sindical, qualquer sindicato, qualquer categoria, a luta se restringe a não perder direitos e não a ganhar direitos (...)então eu acho que a gente tem que olhar para o movimento sindical de uma forma um pouco maior para ver se a gente consegue se encontrar.

Quanto à participação nas plenárias do OP Cidade de sua região e do Plano Diretor Regionalizado, uma pequena parcela declarou ter participado das plenárias do Plano Diretor Regionalizado em seu bairro e/ou do Orçamento Participativo (2001 2004). A grande maioria disse não se interessar por esse tipo de ativismo, por não ter tempo, por "comodidade", "cansaço" ou "inércia". Alguns alegaram não terem sido informados e outra parcela disse que não acreditava nesse tipo de processo, classificando-o como "jogo de cartas marcadas". 
B4 - Ah, a gente fica sabendo (das plenárias), alguém vem, comenta, convida, mas não sei, acho que a gente acaba não priorizando isso (...)

B3 - Eu não participei. Conheço até o programa, ouvi falar muito, mas não participei.(...) acho que por comodismo...

H2 - Eu idem, ficamos sabendo, mas é cansativo e a gente acaba... Final de semana, não é?

I2 - Aqui inclusive foi pólo de reuniões, só que eu não moro aqui, então é até injusto participar de um negócio que não me diz respeito. (...) e as que foram lá onde eu moro, eu fiquei sabendo depois que já tinham acontecido, então não participei de nenhuma (...)

Neste caso observa-se que para o professor (I2) "o lugar de lutas" é apenas onde ele reside e não onde atua profissionalmente: não considera importante intervir nos problemas daquele bairro, embora afetem a comunidade com a qual ele convive e indiretamente também interfira no seu bem-estar já que está inserida no contexto da cidade onde ele mora. O depoimento de outra colega da Escola E, ilustra essa preocupação:

E8 - (...) Participei da canalização do córrego, ali no Jardim Ipanema (...) de conservação das praças e limpeza de entulhos (...). Fui por causa do entorno da escola que estava sujo e o rio ficava próximo da escola, então fui para reivindicar isso.

C6I - (quanto ao Plano Diretor) - (...) Participei onde eu trabalhava, que não é onde eu moro. Nós fizemos várias plenárias. Foi levantado com a própria comunidade e a região onde estávamos atuando, tinha uma Ong que fez um estudo das três regiões mais atingidas pela exclusão social. E foi um fruto muito interessante, porque o que significa planejar a cidade para os habitantes? O que é isso? O que significa ocupar? No caso, a minha região era praticamente $70 \%$ de ocupação. O que significa os terrenos serem regularizados? O que isso implica num sistema democrático e na cidadania de cada um ter o sentimento de pertencer à cidade, não é?

No depoimento seguinte, a professora procura justificar sua decisão de não participar de um desses fóruns de decisão: 
I6 - Eu não participei (do OP) porque o que foi decidido não foi respeitado, não foi sério, isso foi uma balela, uma brincadeira, foi brincar de decidir, igual ao PPP (Projeto Político Pedagógico) da Escola. As coisas têm que acontecer com a comunidade, têm que envolver todo mundo, enquanto isso não acontecer, isso vai ser brincadeira... É por isso que a gente não consegue desenvolver ações na escola porque em tudo, a comunidade precisa apoiar a gente e pra isso ela precisa entender o que está sendo feito, só que as pessoas ainda não se expõem e o professor, o C.P., o Assistente, o Diretor, ainda não se expõem, não se sentem à vontade com a comunidade. No OP foi complicado porque a gente queria decidir algumas coisas sobre o terreno atrás da Escola e isso é muito antigo e aí qual foi a fala do pessoal? Primeiro que ninguém entendia porque foi decidido resolver um problema lá de Pirituba e não daqui... Eu acho que isso precisaria ficar claro e se foi resolvido eu também não tomei conhecimento.

Observa-se nesse depoimento, que a professora (I6) demonstra descrédito no processo, afirma que o mesmo não possui credibilidade, mas ao mesmo tempo, confessa que não participou, portanto, está se referindo a ele a partir de uma representação pessoal que foi construída com base em informações passadas por outras pessoas. O seu depoimento é confuso, pois a seguir se coloca dentro do processo "a gente queria decidir...”, como se tivesse vivenciado as discussões.

Ao mesmo tempo em que acha legítimo não ter participado por não acreditar no seu mecanismo, contraditoriamente critica a falta de participação da comunidade escolar nas ações da escola, em um processo que ela também não considera confiável: “(...) Foi uma balela, uma brincadeira, foi brincar de decidir, igual ao PPP da Escola”.

Reconhece que, para que a comunidade passe a participar da escola, precisa primeiro entender o que está sendo feito, mas os educadores, inclusive a equipe técnica, não se expõem, ou seja, não desejam compartilhar com a comunidade os seus projetos e ações, embora considerem imprescindível o apoio dessa mesma comunidade.

Revela que, apesar da sua opinião sobre o $\mathrm{OP}$, também não procurou saber se o problema do terreno ao lado da escola havia sido resolvido ou não, demonstrando pouco envolvimento com a realidade vivida pela comunidade local: “(...) e se foi resolvido eu também não tomei conhecimento". A resposta da comunidade a essa postura da escola é 
semelhante, pois ela também não quer se envolver com as ações da escola: "As coisas têm que acontecer com a comunidade, têm que envolver todo mundo, enquanto isso não acontecer,isso vai ser brincadeira...”

Para ela, faltou entendimento sobre os dois processos para que houvesse adesão: No PPP - “(...) a comunidade precisa apoiar a gente e pra isso ela precisa entender o que está sendo feito (...).

No OP - (...) Primeiro que ninguém entendia porque foi decidido resolver um problema lá de Pirituba e não daqui... Eu acho que isso precisaria ficar claro (...)

O depoimento de uma professora de outra escola (C6I) explica o comportamento da parcela da população que, como a professora I8, não entendeu o processo e por isso desconsidera o valor que esse e outros canais democráticos possam ter dentro da sociedade. A professora C6I demonstra conscientização sobre a importância da participação ativa da sociedade nas decisões que irão afetar a sua vida e sobre a natureza do processo democrático que exige tempo para que as escolhas feitas beneficiem a maioria:

C6I - (...) eu participei da primeira edição (OP), que eram temáticas de educação e saúde e foi bem interessante, porque o processo democrático demanda tempo, como por exemplo: princípios básicos da democracia: o que vai (ser aprovado) pela maioria (...) - “Não, não, mas eu quero!” - É esse conceito de "maioria" que as pessoas num primeiro momento tinham maior dificuldade de entender... Quando você fala: Olha, pode ser uma escola, pode ser uma creche (que vai ser aprovada). "Mas em que lugar? Ah, não!" Se mais da metade queria num determinado local, mas a outra parte achava melhor o outro, como é que você contemporizava com a outra parte que achava que estava sendo injustiçada? Então, esses conceitos foram interessantes porque é um processo.

Segundo a professora, falta para as pessoas "um olhar diferenciado" para valorizar o que é democrático e compreender o que não é:

C6I - Esse olhar diferenciado é muito importante. Mas agora, as pessoas falam, é uma das críticas que ouço do processo: "Ah, mas muitos terrenos não foram aprovados... ou muitas coisas não foram construídas...". Claro que pode ter sido por " $n$ " motivos, mas (esses terrenos ou coisas) não foram construídos dentro de um processo democrático. Como a escolha de um terreno, por exemplo: às 
vezes o terreno não era condizente para construir um prédio voltado para a educação, (...) ou aquele terreno é em área de manancial, então tem que ser um processo que as pessoas têm que assimilar e isso não é de um ano para outro, isso não é em três ou quatro anos, isso é um processo longo, que demanda investimento e demanda um olhar diferenciado para o que é o OP. (...) não só para o orçamento público, mas também para a sociedade.

A mesma ainda reconhece que existem diferentes concepções de sociedade e para cada qual haverá um tipo de gestão pública eleita para representá-la, mas de qualquer forma reafirma a obrigação de todo cidadão agir como decisor e não como mero expectador.

C6I - É claro que é um trabalho que não tem fim e nós infelizmente tivemos uma ruptura dessa concepção de gestão, dessa concepção de sociedade. Quer dizer, é obrigação de todo cidadão saber para onde vai o seu dinheiro e participar da construção da cidade mesmo, como um todo.

É interessante relembrar a análise de SANTOMÉ (2001), anteriormente apresentada, para quem, professores que exercitam sua cidadania em diferentes espaços, lutando pela democracia e por melhores condições de vida para todos, com certeza incorporarão essas lutas também no espaço escolar, muitas vezes impregnado de incoerências, individualismos e imobilismos construídos ao longo de anos. Os alunos, espelhando-se na postura de seus mestres, também se sentirão atraídos pelas mesmas causas e assim, a adesão progressiva de outros atores da comunidade educativa, permitirá a transformação gradual de todo o ambiente escolar e de seu currículo. A transformação da sociedade será uma conseqüência, ainda que em longo prazo. Foi o que se observou, durante os grupos focais: os educadores que demonstraram ter um maior compromisso com a transformação social, também foram aqueles que, em algum momento de suas vidas desenvolveram uma militância em algum movimento ou instituição ligada à prática da cidadania. Essa militância ficou impressa nas suas práticas pedagógicas (mais democráticas e inclusivas), marcas também presentes no PPP de suas escolas, certamente construído sob essa influência. 
Durante o ano de 2008, surgiu uma nova oportunidade para os educadores dessas escolas se envolverem com um processo de formação cidadã, por meio de um curso de extensão promovido pela Escola de Artes, Ciências e Humanidades (EACH) da USPLeste em parceria com o Fórum pelo Desenvolvimento da Zona Leste e o Instituto de Pesquisas e Estudos de Governo. Este curso, denominado "Zona Leste Cidadã”, foi oferecido aos diferentes segmentos das escolas públicas e outros órgãos governamentais da região, moradores, representantes da sociedade civil organizada, empresários, entre outros e teve a duração aproximada de dois meses, tendo sido realizado aos sábados, com encontros de quatro horas. A autora deste trabalho, bem como alguns colegas (professores, coordenadores pedagógicos e diretores) integrantes dessa pesquisa das escolas A, B, F, G e I, entre outros de várias outras escolas participaram do referido curso. É verdade que o número de inscritos superou as expectativas dos organizadores, mas também não se manteve até o final. Uma parte dos educadores desistiu logo nos primeiros encontros, alegando que não se afinava com as discussões políticas que o tempo todo estavam sendo postas, ao contrário dos integrantes dos movimentos sociais e entidades do bairro, pessoas simples, mas de grande consciência política e responsabilidade social.

Essa outra possibilidade de observação dos mesmos educadores ora entrevistados acrescentou mais evidências às constatações que já haviam sido feitas ao longo dessa pesquisa, quer em relação aos educadores que desistiram, ou em relação aqueles que permaneceram e desenvolveram trabalhos importantes no final do processo. O principal destaque dessa iniciativa referia-se justamente à oportunidade de integração das pessoas de diferentes áreas de atuação social e ao conteúdo científico e também político desenvolvido. Ele subsidiaria as discussões que viriam mais tarde sobre os principais problemas da Cidade e especificamente da região, nas áreas da educação, saúde, meio ambiente, transportes, habitação, desenvolvimento econômico, entre outros.

Para a avaliação e certificação do curso, os participantes deveriam formar grupos de trabalho (de educação, saúde, meio ambiente...) investigar e buscar soluções para os problemas identificados em cada área. Dois dos educadores participantes desta pesquisa 
(escolas A e I), bem como a autora da mesma, constituíram o grupo de meio ambiente. Os demais se juntaram ao grupo de educação.

As pesquisas realizadas em campo e as devidas propostas de intervenção foram socializadas ao término do curso em uma plenária ocorrida na USP-Leste. Posteriormente estas foram incorporadas às pautas de reivindicações dos moradores locais e do Movimento Nossa São Paulo, cujas lideranças foram também colaboradoras do curso. O documento elaborado foi entregue às autoridades públicas e candidatos ao Legislativo e Executivo dos diferentes partidos, durante debates promovidos por várias Entidades e pelo Fórum pelo Desenvolvimento da Zona Leste, aproveitando o momento eleitoral que estava se iniciando. Foi um trabalho gratificante que permitiu aos envolvidos colocar em prática tudo o que já foi discutido sobre a prática da cidadania, o exercício do magistério e valorização do diálogo 'na' e 'com' a diversidade, tendo em vista que a heterogeneidade do grupo seja do ponto de vista da origem social, da formação cultural e intelectual, bem como das ideologias políticas foi um diferencial importante.

Vale lembrar que não foi surpresa para esta pesquisa, o fato de encontrar no curso mencionado, os mesmos professores que já haviam demonstrado sua consciência política durante as sessões de grupo focal realizadas nas escolas. Alguns desistentes também foram coerentes com as posturas reveladas na mesma ocasião, quando se tratava de reconhecer a sua própria inércia frente aos problemas que enfrentavam dentro e fora da escola. Esse comportamento também demonstra sintonia com a pesquisa realizada pelo Jornal Folha de São Paulo (MELLO \& BEDINELLI, 2008 e SPINELLI \& BEDINELLI, 2008), denominada "DNA Paulistano" onde se revelou que a metade da população de São Paulo não tem interesse em política e que esse desinteresse se amplia significativamente em bairros com pior infra-estrutura. Dentro desse universo, na zona leste da Cidade, mais especificamente, nos bairros onde estão inseridas as comunidades escolares pesquisadas, encontra-se o maior número de moradores que não participam de movimentos sociais $(33 \%)$ e nem se interessam por política $(51 \%)$ ou cultura $(77 \%)$. 
Observa-se assim, que a Escola reproduz comportamentos e situações identificadas na sociedade, demonstrando o que já foi discutido anteriormente sobre o peso da influência que uma exerce sobre a outra.

\section{V - Quanto ao protagonismo infanto-juvenil na escola: parecer dos educadores e contribuição dos educadores nos projetos da escola:}

Embora se dissessem favoráveis à educação ambiental, a democracia participativa e ao protagonismo dos alunos, a maioria dos professores confessou ter tido participação mínima ou nenhuma participação nos projetos voltados para educação ambiental que chegaram a ocorrer na escola. Segundo eles, outros colegas conduziram os projetos e geralmente de forma solitária, enfrentando uma série de dificuldades na escola. Os depoimentos de professores que participaram ativamente desses projetos revelaram que foi uma experiência bastante positiva e recompensadora, mesmo confirmando todas as dificuldades que vivenciaram e que foram citadas pelos demais colegas. Para eles, a mudança de postura dos alunos, o envolvimento, também relatado pelos próprios alunos em suas entrevistas, a alegria, trouxeram um sentimento de realização profissional e pessoal. O Orçamento Participativo aconteceu em todas as UEs pesquisadas, enquanto as Conferências Infanto-Juvenis do Meio Ambiente ocorreram em apenas metade delas.

E1I - Bom, com o Orçamento Participativo- Criança, eu me envolvi bem diretamente. (...) Valeu muito a pena porque os alunos que nem sabiam que tinham idéias, que eram responsáveis, acabaram percebendo que eles eram capazes de alguma coisa, de ir para cima e mudar: 'Minha proposta é importante, por isso, isso e isso'. Eles aprenderam a argumentar e isso contribuiu bastante, não só na região que a gente estava trabalhando e eles se sentiram extremamente importantes por estar decidindo e chamando o outro para a realidade: 'Ei, você tem que participar!' ou 'Você é delegado, tem que ter postura!'. Foi muito bom, pena que acabou.

F7 - Eu participei das duas (Conferências de Meio Ambiente); A primeira foi muito boa, os alunos estavam envolvidos, interessados (...) e os resultados também foram muito positivos. Houve bastante clareza nas comunicações, (...) muitos alunos aproveitaram para refletir, para conhecer sobre a região, para 
discutir sobre o relacionamento deles dentro da escola, para perceber as transformações que aqui a região estava vivendo, reformas feitas no bairro (...)

B3 - (...) Eu trabalhei na minha outra escola e lá eu participei, fiz o curso (OP), movimentei toda aquela criançada, trabalhava na sala de informática e assim eu achei aquilo uma maravilha! (...) você cria uma chama nessa criançada que se tivesse continuidade eu acho que ninguém mais segurava (...) é uma coisa bastante motivadora para as crianças (...) é uma forma de você mostrar qual é a força que a gente tem quando se une, quando a gente conversa, tem as mesmas propostas. Eu realmente acho que o OP foi demais!

E1 - Eu acho de extrema importância, porque é um dos meios que a gente tem para formar aquele cidadão que a gente disse lá atrás: o cidadão criativo, o aluno-cidadão, quer dizer, o aluno feliz, se ele não está treinando a autonomia, as idéias que ele tem, ele não vai conseguir então nós temos que dar essa oportunidade pra esse aluno ter essa autonomia.

Alguns professores ressaltaram que a escola, de forma geral, não está preparada para o protagonismo de seus alunos, porque têm medo de perder o controle da situação, gerando indisciplina.

C3I - Nós não sabemos lidar com essas questões. (...) você fala muito no aluno crítico, mas quando o aluno te responde e te faz pensar na sua ação, aquilo incomoda e você não sabe como dar rumo a isso.

Para eles, os alunos também não estão preparados para esse grau de liberdade e acabam se tornando relapsos com os outros deveres escolares (os oficiais), enfrentando os professores quando são cobrados disso. Alegaram ainda, que alguns pais não concordavam com a saída dos seus filhos da sala de aula para desenvolverem atividades extraclasse, por entenderem que "a matéria" dada de forma convencional em sala de aula era mais importante para o seu aprendizado. Esta situação remete ao quadro descrito por SANTOMÉ (2001), onde os pais reagem negativamente às novas pedagogias, pois foram educados de forma tradicional e precisam ser convencidos da eficiência desses novos métodos. Também para esses professores, são mais seguras as "velhas práticas", com as quais já estão habituados e que lhes dão "um pouco mais controle" sobre os alunos, embora não sejam eficientes para transformá-los naqueles cidadãos por eles imaginados. O ambiente autoritário, individualista e, portanto, antidemocrático presente nas UEs, acaba por interferir na saudabilidade do ambiente 
escolar, na visão de alguns dos professores, contraditoriamente é defendido, quando se trata de dar espaço aos educandos.

E7II - (...) Ele (o aluno) precisa ser protagonista dessa história, só que a escola tem um tremendo vício, que é de estar muito em cima de tudo, de não confiar muito no trabalho das mãos deles, porque a gente sempre acaba achando que não vai sair se a gente não estiver em cima (...)

F7- (...) a estrutura existente é muito conservadora, então o protagonismo dos alunos é muito sufocado dentro da escola. O pouco que eles tentam participar é sufocado e então eles acabam por se 'acalmar', se desinteressar e não lutar mais por isso.

D1 - Eu também vejo que o protagonismo infanto-juvenil na nossa escola é o resultado de ações também isoladas, fragmentadas, dissociadas dos projetos mais amplos, fruto de um momento ou de uma ação de um professor, neste ou naquele projeto, também muito pessoal, muito particularizado. (...) Poderíamos abrir mais espaço para o protagonismo,(...) mas muitas vezes, não é aberto por insegurança do professor, por medo de perder o controle (...). Muitas vezes o professor tem medo de ceder esse "seu” espaço para o aluno (...)

H2 - Nós tivemos um problema, porque esses encontros do OP e desses outros projetos de democracia, tiravam muito o aluno da sala de aula e os pais (reclamavam), acho que com razão, você se coloca do outro lado e vê: Como é que meu filho vai sem conteúdo prestar uma prova, um cursinho, entendeu? A gente desse lado pensa de uma forma e eles pensam de outra, até mesmo porque os conhecimentos são diferentes, não é? Então nós tivemos problemas muito graves com essa questão do aluno ter que fazer o curso dentro do seu horário de aula, porque ele perdia prova, ele perdia conteúdo na sala, porque o professor que estava lá, ele não estava envolvido com isso, ele queria saber da matéria dele e está certo! Porque ele não sabe o que está acontecendo, ele não sabe que (o aluno) está fazendo do curso do OP.

Essas barreiras descritas pelos educadores reforçam as constatações anteriormente descritas por CESAR (2000), GADOTTI (2000), MUÑOZ (2004) e SANCHO (2006) entre outros autores, sobre a estrutura escolar e os espaços de participação para as crianças e adolescentes: A escola está preocupada em "fazer a cabeça" e não em "encher a cabeça de idéias"; Está muito mais aberta à competitividade dos seus atores do que à solidariedade e o compartilhamento de idéias e responsabilidades; O aluno ainda é visto como aquele do "ainda não"; a burocracia e as 
decisões hierárquicas têm mais força do que a autonomia e a criatividade dos atores escolares.

A falta de comunicação, ou o desencontro de informações dentro da escola e desta com outros órgãos educacionais como as Coordenadorias de Educação e a própria Secretaria, é um fator importante a ser considerado para que os projetos se desenvolvam de forma satisfatória nas escolas e contem com o tempo adequado para o planejamento das ações e o envolvimento de todos. Alguns professores relacionaram os resultados das Conferências ou do OP-Criança a esses fatores supracitados:

F7 - (...) a segunda eu já achei que não houve um envolvimento muito grande, que não houve também muito espaço para que eles discutissem e se envolvessem. Também não houve muita clareza nas comunicações internas, então nem todos os professores estavam bem informados sobre como deveriam ter desenvolvido o trabalho e também foi dado pouco tempo e liberdade para desenvolver, então o resultado também não ficou tão elevado (...).

H3 - Eu achei que foi positivo, mas que a gente deveria ter tido um preparo com uma boa antecedência. Nossa! Quando chega, corre, vai, e de repente nem chegou muito em cima da hora, mas o processo de comunicação da escola com a Diretoria de Ensino (Coordenadoria de Educação) e professores é uma coisa muito lenta, que às vezes chega pra nós com uma semana para resolver. Então seria uma coisa muito melhor se fosse bem planejada e com material para a gente, ficaria bem mais simples e atingiria mais pessoas.

\section{Os desdobramentos dos grupos focais em três escolas participantes da pesquisa (B, E e I):}

A seguir, serão discutidos aspectos sobre o acompanhamento de projetos em três das escolas participantes da pesquisa, conforme mencionado no início da análise dos resultados dos grupos focais:

A assessoria para construir uma Agenda 21 Escolar, com foco na qualidade de vida, foi dada às escolas B e E. Ela foi iniciada no final de 2006 (Escola E) e no segundo semestre de 2007 (Escola B) com uma pesquisa envolvendo alunos, 
professores, pais e funcionários sobre o que poderia melhorar na escola para garantir uma melhor qualidade de vida para a comunidade educativa. Nesse processo, o Grêmio Estudantil da Escola B e os professores orientadores da informática educativa (POIEs) das duas escolas foram acionados para mobilizar a comunidade educativa, auxiliar na tabulação dos dados e na divulgação dos resultados.

$\mathrm{Na}$ Escola B, algumas ações decorrentes dos resultados das eleições de 2007 sobre os fatores importantes para a qualidade de vida na escola começaram a ser desenvolvidas no mesmo ano e em 2008, como: campanha para a limpeza da escola, coleta seletiva e reciclagem, alimentação saudável, conservação do prédio e da área verde da escola, implantação de salas-ambiente. As mudanças no quadro docente (remoções) e na direção nesse período contribuíram para retardar algumas ações e retroceder em outras, como a revogação da decisão de mudar a organização das salas de aula convencionais para salas-ambiente, (uma forma diferenciada de organização do espaço e do trabalho pedagógico), apesar da decisão da comunidade escolar. Esse processo foi feito sem qualquer avaliação ou nova consulta a esses segmentos.. Isso gerou desmotivação entre alunos e professores que deixaram de participar de outras ações do projeto "Qualidade de vida na escola". Também não houve qualquer tipo de envolvimento da Coordenação Pedagógica em nenhuma etapa desse processo, ficando a cargo de apenas um grupo pequeno de professores e alunos. Nesta Unidade, em especial, há um histórico de descompromisso e ineficiência de integrantes da equipe técnica, que reiteradamente se omitiu do seu papel de dirigir, organizar e viabilizar as ações pedagógicas, sobrecarregou o quadro docente com tarefas burocráticas inúteis para o processo de ensino-aprendizagem e por inúmeras vezes agiu de forma arbitrária, manipulativa, desconsiderando as opiniões dos demais membros da comunidade escolar ou as decisões já tomadas no coletivo. Esses eventos, entre outros, vem sendo alvos de denúncias de professores, pais e alunos na Coordenadoria de Educação, que tem procurado investigar as mesmas. No entanto, a morosidade da máquina administrativa neste caso, tem agravado a situação da escola que continua à mercê dessas situações conflituosas, gerando um ônus insustentável para educadores e alunos.

Somente no caso da Escola E, onde o projeto foi bem sucedido, houve o acompanhamento sistemático das coordenadoras pedagógicas que lideraram o processo e mobilizaram todo o corpo docente e estes, envolveram funcionários, alunos e pais. Os 
resultados positivos foram dispostos em um Blog construído pela Escola na Internet em 2007. A facilidade com que este projeto foi absorvido por aquela comunidade escolar se deve, sem dúvida, ao longo caminho já percorrido pela equipe técnica e docente que sempre tiveram preocupação com a formação política de seus educandos e deles próprios.

Já na Escola I, a pesquisadora foi convidada pela direção para subsidiar um projeto de implantação do Grêmio Estudantil, visando incentivar o protagonismo dos alunos e ampliar a democracia participativa nos processos decisórios dentro da Unidade. Essa assessoria se deu em dois momentos: uma palestra no final de 2006 proferida aos alunos, mas que também contou com a presença da direção, professores e funcionários sobre o que representava o protagonismo infanto-juvenil e como ele poderia ser desenvolvido naquela Escola.

O segundo momento ocorreu em 2007, durante um semestre em que a pesquisadora trabalhou com um grupo de alunos que tinham interesse em formar chapas para concorrer às eleições do Grêmio no ano seguinte (2008). Nessas reuniões houve a participação espontânea de apenas um professor de educação física, que havia participado do grupo focal e que já há alguns anos tinha um trabalho diferenciado com seus alunos em projetos como o Orçamento Participativo Criança em 2003 e 2004. Conforme a proposta acertada com a direção, após a formação dos alunos, a escola iniciaria o processo de eleição e deveria indicar um ou mais professores para acompanhar o Grêmio durante a vigência de seu mandato, no entanto, nenhum professor se dispôs a exercer esse papel e os alunos, por sua vez, não dispunham da bagagem e da responsabilidade necessárias para fazê-lo sozinhos.

Não houve, em nenhum momento, a participação da coordenação pedagógica ou da direção nessas reuniões, embora tenham sido apresentados relatórios regulares sobre as atividades desenvolvidas ao longo do trabalho com os alunos por parte da pesquisadora.

Observou-se uma profunda desarticulação do grupo docente e descontentamento com as relações de poder dentro da Escola, manifestadas em várias oportunidades, desde o grupo focal realizado com os professores até a pesquisa de opiniões, que foi 
encaminhada pelos alunos da Comissão pró-Grêmio a todos os segmentos da escola, com o objetivo de levantar aspectos que deveriam ser melhorados para garantir um ambiente mais saudável na Unidade e que seriam utilizados como referências pelas chapas que iriam concorrer ao Grêmio.

Assim, o trabalho não surtiu o efeito catalizador de forças como se esperava, para finalmente colocar em prática uma política de relações mais democráticas e saudáveis dentro da Escola, que embora, através da sua direção, tivesse "encomendado" um trabalho de sensibilização para implantar um processo democrático de gestão, por meio do Grêmio Estudantil, não se mostrou inteiramente disposta e preparada para assumir as responsabilidades coletivas que um projeto como esse demanda. 


\section{2 - ENTREVISTAS COM OS ALUNOS E EX-ALUNOS:}

Participaram das entrevistas, vinte e um alunos de nove escolas: Três da escola A, três da Escola B, um da Escola C, um da Escola D, três da Escola E, dois da Escola G, dois da Escola H, quatro da Escola I e dois da Escola J.

Embora fosse intenção da pesquisa entrevistar pelo menos dois alunos ou exalunos de cada U.E., isso não foi possível por diferentes motivos: Os alunos indicados pelas suas Escolas não compareceram às sessões de entrevistas que foram remarcadas várias vezes; as escolas não conseguiram contato (ex-alunos); alguns alunos se esqueciam de trazer a autorização dos pais; outros não se dispuseram a participar e a escola não indicou substitutos. Em uma das escolas, (F), a pesquisa foi interrompida antes dessa etapa, por decisão da direção. A possibilidade de desistência da pesquisa estava prevista no Termo de Consentimento Livre e Esclarecido, cumprindo as exigências éticas expressas pela Resolução 196/1996 - CNS, sobre pesquisas científicas. Portanto, a direção da escola $\mathrm{F}$ informou à pesquisadora, logo após a realização do grupo focal, que não desejava continuar, pois considerava que a mesma estava "gerando tumulto na rotina escolar" (embora as sessões de grupo de focal tenham ocorrido dentro do horário de estudo coletivo dos professores e, portanto, fora do horário de aulas dos mesmos) e que a escola não dispunha de espaço adequado e nem de tempo disponível para a realização de entrevistas com os dois alunos e seus respectivos pais, bem como para o preenchimento do questionário destinado as equipes técnicas. A decisão da escola foi acatada pela pesquisadora.

\section{I - Quanto à democracia na escola:}

a) - Opinião sobre como deveriam ser os processos decisórios e como se dá a participação dos alunos nas decisões: 
Com exceção de uma resposta, em que se sugere maior rigidez por parte da escola para com os alunos, limitando sua liberdade e neste caso, o papel destes surge como o de meros objetos ou executores das decisões tomadas, todas as demais respostas indicaram que os alunos deveriam estar presentes nos momentos decisórios, sendo mais ouvidos e assumindo a posição de decisores (ao lado dos professores, direção, funcionários e pais):

A2 - Eu acho que os alunos deveriam ser consultados para que eles tivessem mais envolvimento. Não só os alunos, como os pais, a comunidade para ver os projetos que eles querem, o que eles acham na escola, o que está bom, o que precisa manter e o que precisa modificar (...).

D1 - Em conjunto. Acho que deveriam se tomadas envolvendo todo mundo que participa da escola: pais dos alunos, a comunidade próxima da escola, os alunos, os professores, a direção... Todos têm que participar, porque de uma maneira ou de outra, a decisão vai acabar atingindo todo mundo.

A maioria dos alunos disse que já foi convidada a participar de alguma decisão da escola, embora essas oportunidades fossem raras e neste caso, o canal mais citado foi o Conselho de Escola, órgão que costuma ter um número restrito de vagas com direito a voto, para cada segmento da Unidade Escolar. Outros citaram o OP-Criança e o Grêmio quando estes existiam (anos anteriores) e outra parcela considerou que "participar" significava ser "comunicado" das decisões por meio de bilhetes enviados pela Direção para os pais. Para alguns deles, mesmo quando a escola convida, muitos alunos não se interessam em participar.

E2 - Sim, mas não é a maioria que participa. Tem o grêmio (o ano passado), esse ano ainda vai ter eleição, tem o conselho de escola e os projetos, mas nem todos os alunos participam desses projetos porque não se interessam. Parece que não têm tanta responsabilidade. Todos ficam sabendo porque é divulgado.

Por outro lado, observou-se um esforço particular de um grupo de alunos do Conselho de Escola, que compreendeu que a participação de todos era imprescindível para que a decisão tomada por eles fosse legítima, atendendo às expectativas da maioria dos colegas:

H2 - É difícil participar, mas quando (...) teve a eleição de uma Coordenadora e Diretora, os alunos do conselho foram às salas para pegarem os votos, $e$ verem a decisão dos alunos, porque não adianta nada dez alunos do conselho 
votarem e os outros ficarem sem participar, né? Porque não são só esses dez que fazem parte da escola...Aí conseguimos os votos dos alunos ficando os quatro períodos na escola durante dias.

Observou-se aqui, que as informações não atingem a todos como deveriam e que a escola não prioriza essa questão, inviabilizando uma participação mais expressiva dos alunos:

I2 - Não, só alguns (são chamados a participar), porque se não corrermos atrás, não participamos.

A1 - Não, (...) eles raramente avisam a gente, sabe... Quanto ao conselho, avisam, mas de última hora, eles avisam e dispensam a gente.

C1 - Eu acho que os alunos deveriam ser mais informados sobre as decisões que estão sendo tomadas ou que vão ser tomadas, porque agora nós não somos mais envolvidos que nem antes. Antigamente, tinha o OP-Criança, tinham muitos projetos, mas agora todo mundo está sem interesse pra fazer isso.

\section{II - Quanto às oportunidades de participação de crianças, adolescentes e jovens na política das três esferas de poder político do País: percepção dos alunos:}

Novamente os alunos se consideraram excluídos da participação nas políticas dos diferentes governos que afetam suas vidas. Segundo eles, os políticos nunca se interessam em ouvir as opiniões, sugestões e necessidades das crianças e adolescentes no País. O Orçamento Participativo-Criança (OP-Criança) e as Conferências InfantoJuvenis do Meio Ambiente foram citados como exceções, mas também, sem garantia de continuidade. Por isso, ao serem perguntados se eles se sentiam ouvidos pelos políticos, eles responderam:

H1 - Eu acho que não, eles estão muito ocupados, querendo fazer propaganda do que eles fazem e acabam fazendo propaganda do que eles não fazem e não ouvindo a gente.

H2 - Não, é bem difícil os políticos se interessarem pela população, eles nem estão ligando prá isso, muito menos para as crianças (risos).

I2 - Não, para eles nós somos nulos. 
D1 - De uma maneira geral, não. Mas acho que eles estão começando a perceber que o jovem também fala, pensa, que ele vai ser o futuro, sabe? Então, ele também tem que falar e esse processo da Conferência InfantoJuvenil do Meio Ambiente que aconteceu agora (...) eu acho que é uma forma de escutar o jovem, de escutar o que ele tem para falar, o que ele acha que deveria ser feito para ele mesmo poder colher no futuro.

III - Quanto aos projetos institucionais sobre protagonismo infantojuvenil entre os anos 2000 e 2007, como o OP-Criança, Conferências Infanto-Juvenis do Meio Ambiente ou outros relacionados à saúde e ao meio ambiente:

a) - Ocorrência dos eventos na escola e participação dos alunos:

A maioria dos alunos entrevistados teve participação em pelo menos um dos dois primeiros eventos citados acima. Três deles participaram das duas versões de OPCriança e das Conferências Infanto-Juvenis do Meio Ambiente e apenas quatro deles não teve participação em nenhum dos dois eventos, mas participaram de outros projetos relacionados ao protagonismo, saúde e meio ambiente.

A3 - Não cheguei a participar das Conferências, apesar de ter discutido algumas vezes em reuniões do OP-Criança, do Grêmio, a gente chegou a discutir coisas que envolviam meio ambiente (...), do OP-Criança fui delegada da escola e depois da Subprefeitura (...).

B3 - Participei no ano passado (2005) que teve (a II Conferência InfantoJuvenil do Meio Ambiente). Fui eleita delegada da sala e ganhei em segundo lugar (na escola), não cheguei a ir, mas meu cartaz foi (para Brasília).

C1 - Já, em 2004, depois disso nunca mais ninguém falou nisso (OP-Criança), nem tocou no assunto.

Alguns alunos fizeram questão de descrever sua experiência de forma detalhada, ora explicitando os pontos fortes...

D1 - Eu participei da $2^{a}$ Conferência Infanto-Juvenil do Meio Ambiente que aconteceu em 2005, inclusive eu fui escolhida para representar a minha escola em Brasília. A gente foi para Brasília (...) passou uma semana lá. Ficamos em um hotel, todo mundo junto: jovens do país inteiro, inclusive os facilitadores que 
eram os monitores, pessoas que tomavam conta da gente. Tinha gente de fora do Brasil, (...) do Uruguai, do México, da Bolívia. (...) Foi uma experiência incontável (sic), porque eu conheci, (...) falei com pessoas que eu achava que jamais fosse falar na minha vida. Eu tentei falar espanhol, as pessoas falavam comigo assim e eu tentava responder o que eles me perguntavam, foi muito engraçado. A gente viu o Presidente bem de perto, eu inclusive tenho fotos com a Ministra Marina Silva, do Meio Ambiente. A gente participou de uma caminhada da Esplanada dos Ministérios até o Palácio do Planalto, onde a gente entregou a Carta de Responsabilidades para o Presidente. Essa Carta foi elaborada por nós, os jovens participantes da Conferência. A gente elaborou com todas as responsabilidades que estávamos assumindo, como íamos cuidar do Brasil, fazer essas responsabilidades virarem projetos e quem poderia nos ajudar. (...) Nós entregamos, isso virou um documento oficial e está na mão do Presidente. Então agora é só a gente ter força de vontade, não desanimar, coloca para frente, assumir mesmo as responsabilidades, porque não adianta só por no papel, sabe... Assinar lá e dizer: "eu participei" - não, você tem que participar, (...) colocar em ação, senão não adianta nada.

... Ora reconhecendo os pontos falhos:

E3 - Já (participei), no ano retrasado (2004). Foi muito legal, o OP-Criança, a Conferência, só que votaram (de forma) inconsciente. Eu, por exemplo, também votei inconsciente (...) em uma menina que eu gostava, só que eu era novo, estava na $6^{a}$ série (...), mas se fosse ter a mesma coisa (agora) eu não iria votar inconsciente, eu iria votar pelas propostas.

b) - Percepção acerca da contribuição dos projetos para o desenvolvimento da cidadania dos participantes:

Percebeu-se pelos depoimentos, que houve uma tomada de consciência e de formação de valores durante esse processo, pois os projetos mencionados apareceram como fatores positivos que influenciaram na postura dos educandos dentro e fora da escola, tornando-os mais responsáveis e ativos em relação à cidadania.

A3 - Eu acho que aprendi muito: ver como são as pessoas e como é o trabalho de um funcionário dentro da escola. Porque é assim, quando você é simplesmente aluno, não participa de nada, eu acho que você fica meio cego do papel de pessoas, você não enxerga as responsabilidades das pessoas. Quando você começa a participar disso, você vê que nem tudo é tão simples, que há muita burocracia, muita barreira. Você percebe que as pessoas não são como você pensa que elas são. Eu aprendi a ter muita paciência, a lutar por aquilo que eu quero, entendeu? Aprendi a debater, a argumentar (...), a convencer também as pessoas, a mostrar para as pessoas o que era melhor (...), então aprendi muita coisa. 
B1 - Ah, o que eles trouxeram de bom para mim (foi a consciência de) que o meio ambiente é uma coisa que a gente tem que conservar. A discriminação (das pessoas), isso não é bom, porque ninguém gosta disso e são coisas que você pode aplicar fora da escola também. É isso!

E3 - Conscientizar a gente a fazer as coisas, por exemplo, cuidar do meio ambiente, para a gente aprender a votar (...) e no futuro não votar errado, eleger pessoas que não prestam para nosso governo (...).

H1 - Bom, eu acho que dentro da escola uniu mais os alunos, estimulou mais a gente a participar, a querer melhorar mesmo e fora da escola também você acaba levando (...) para dentro de casa, como aprender a preservar certas coisas (...).

D1 - (...) Vou falar pela Conferência: antes eu não estava nem aí se eu jogasse um papel de bala no chão, por isso eu jogava (...) e para mim era só mais um papelzinho (...) agora (...), eu fico pensando: Onde esse papelzinho vai parar? (...) vai parar em um rio e quando vier uma chuva vai alagar e eu vou ser responsável, um pouquinho, mas vou ser responsável por aquelas famílias que perderam tudo (...) e eu não quero isso, sabe? (...) então, tudo isso eu posso evitar e eu tomei consciência (...) depois da Conferência. $O$ que trouxe de bom foi que eu penso muito mais nos meus atos agora antes de fazer.

É importante ressaltar que a aluna D1 já não pertence mais à escola D, mas tornou-se voluntária no ano seguinte, após concluir o primeiro grau, auxiliando os professores da Sala de Leitura e Informática nos projetos com os alunos e também os funcionários com a manutenção da limpeza dos espaços da escola (assim como os alunos G1 e G2 na escola G).

Quando foi questionada pela pesquisadora, sobre ter sido ou não ouvida durante a Conferência Nacional em Brasília, a aluna respondeu:

D1 - Claro, eu senti que quando eu falei na Carta de Responsabilidades, inclusive a minha proposta foi uma das mais votadas (...) eu me senti muito importante (...) eu falei: "Nossa, a minha proposta vai para a mão do Presidente, vai virar uma coisa que o Brasil inteiro vai ficar conhecendo". Se mais para frente eu souber que uma pessoa, pode ser uma só, está fazendo aquilo que eu dei a idéia lá na Conferência, eu vou ficar muito feliz. Para mim é a sementinha que eu plantei hoje e que, se Deus quiser, eu vou colher amanhã.

Metade dos alunos entrevistados citou outros projetos onde eles se consideraram protagonistas, como: EDUCOM.Rádio, Grêmio Estudantil, Academia Estudantil de 
Letras, Horta, Xadrez, Teatro, Vamos Combinar (sobre sexualidade), projetos sobre o meio ambiente desenvolvidos em parceria com o SESC-Itaquera, Campeonatos, Fanfarra, Conselho de Escola. Em alguns casos mais de um desses projetos estavam presentes na mesma escola. A outra metade disse que já existiram e hoje não há mais nada.

G1 - Existe a horta, o Vamos Combinar, o Grêmio Estudantil, o Educom, que é um estúdio de rádio que a gente tem e a gente faz programas, falando de notícias da escola, o que acontece, (...) a Academia Estudantil de Letras, o Xadrez e os campeonatos que acontecem com outras escolas.

B1 - O Educom que teve até o ano passado (...) só que acabou esse ano. Era uma Rádio que a gente fazia programas sobre o meio ambiente, sobre a escola, sobre tudo (...) as matérias da escola que a gente aprendia (...). Nós que manipulávamos os aparelhos, cada um tinha a sua função e foi muito bom, só que este ano infelizmente não está tendo. Tem o Grêmio, que já teve eleição, mas ó que até hoje não aconteceu nada, não fizeram nada na escola. Tem fanfarra também, que incentiva e todo mundo gosta.

A2 - Ah, só o OP-Criança que foi em 2003/2004, o Grêmio e a Rádio.

c) - Opinião sobre a responsabilidade pelo fracasso dos projetos nas UEs:

A maioria dos alunos atribuiu a responsabilidade pelo desaparecimento ou insucesso de projetos na escola aos segmentos presentes na própria escola (alunos, professores, direção). Alguns citaram também a falta de envolvimento dos pais, porém em geral não conseguiram diferenciar os projetos governamentais daqueles que nascem dentro da própria UE e nem a possível relação entre o que ocorre ou deixa de ocorrer na escola e os diferentes governantes que comandam as políticas educacionais, por exemplo.

H2 - Ah, pela desorganização... Tem muito aluno que não tem organização. Até mesmo a diretora, os professores (...).

I1 - Porque ninguém tem interesse: alunos, professores (...) 
Uma visão diferenciada, que inclui diferentes responsáveis, pode ser constatada pelo depoimento da aluna que passou pela experiência de conhecer os mecanismos governamentais, quando esteve em Brasília, participando da Conferência Nacional Infanto-Juvenil de Meio Ambiente:

D1 - Eu acho que um dos fatores que mais contribui para isso é a mudança de governo. Porque o Educom.Rádio começou no governo da Prefeita Marta(...). Estava a todo vapor. Quando ela saiu, que entrou o Prefeito Serra, 'já deu uma esfriada', já não tinha mais verba (...), não tinham mais os encontros que a gente fazia (...) não tinha manutenção dos aparelhos (...). Acho que há falta de interesse das pessoas da escola também: os professores que não querem assumir, não querem trabalhar fora do seu horário (...) então isso contribui também, mas um dos mais importantes é esse do governo.

Essa outra aluna, que teve a mesma participação, porém apenas em nível de Subprefeitura, como candidata eleita da região, creditou à estrutura de poder montada na escola, na educação voltada para a competição e não para a cooperação, as razões principais de todo o problema, a exemplo do que foi explicitado também por alguns educadores quando questionados sobre as dificuldades da escola em lidar com o protagonismo dos alunos. Durante o grupo focal realizado na escola A, na qual a referida aluna estudava e tinha uma participação ativa em todos os projetos, ela teve seu nome citado por alguns professores como sendo um exemplo de "aluna inconveniente, que não sabia o seu lugar", pois questionava até o posicionamento dos professores em determinadas situações:

A3 - Eu acho que a culpa é de todos, mas eu acho que é como eu falei: (...) que eles acabam justamente por causa da divisão do poder, porque geralmente as pessoas não querem dividir o poder com outras pessoas e dentro de uma escola existe muita competição, entre, por exemplo, até mesmo entre projetos. Uma pessoa é do EDUCOM, ela vai ter que concorrer com uma pessoa do Grêmio, do OP, entendeu? E com o pessoal que trabalha na escola. Então essa divisão de poder está sempre colocando um contra o outro, ao invés de ser uma coisa assim, integrada, todo mundo unido, porque às vezes eles estão em prol de uma mesma coisa que é uma escola melhor.

A resistência da escola em ampliar os espaços de ação dos alunos e a visão contrária dos pais acerca de atividades extraclasse, igualmente citadas pelos educadores 
como fatores limitantes do protagonismo, também surge aqui, embora esta seja uma opinião solitária, dentro do universo de alunos aqui entrevistados.

A3 - Também deixa de existir porque gera muita polêmica, os alunos saírem da sala de aula, isso aí também foi com certeza um ponto que foi alegado para terminar com esses projetos. Porque fica complicado você ter os alunos fora do período de aula, mas também não é o ideal o aluno perder aula para participar desses projetos.

Esta aluna ainda reconhece que também cabe aos alunos "brigarem" por esse espaço dentro da Escola e não ficar esperando que as coisas aconteçam somente quando os adultos decidem que elas devam ocorrer:

(...) Mas foi culpa dos alunos que quando os projetos surgiram eles deveriam ter insistido para uma continuação, para ter seu espaço, porque era uma forma de você ter um espaço maior, aprendendo coisas, exercitar a sua cidadania (...), o seu protagonismo. Então, não existe um (destaque da aluna) culpado, existem essas circunstâncias que fizeram com que eles terminassem.

d) - Percepção sobre a saúde ambiental em suas escolas:

Apenas uma pequena parte dos alunos considerou o ambiente de sua escola “totalmente saudável”. Para a maioria, ele não é saudável ou "nem sempre é saudável", por diversos fatores: falta limpeza, higiene, há presença de ratos, muito barulho, vandalismo, falta segurança e respeito entre as pessoas. Observou-se que, pelo número de citações, as relações interpessoais para esse grupo, apareceram num segundo plano, ao contrário dos professores, onde essa questão mostrou-se muito importante em toda a pesquisa.

A1 - Tem algumas coisas saudáveis, mas sempre que minha escola se torna um ambiente saudável, tem sempre alguém que vai lá e estraga, pichando, escrevendo alguma coisa, porque têm vândalos, essas coisas sabe... Então não é totalmente saudável.

A3 - Não, porque um problema que eu acho que tinha muito na minha ex-escola era a falta de limpeza, entendeu? Acho que principalmente nos banheiros, não tinha papel higiênico, então era uma coisa meio desagradável e pouco saudável; Não tinha aquela limpeza, aquela organização (...). 
I1- Não, porque fala higiene.

$H 1$ - Eu acho que não, por questões de organização (...) e de segurança(...) também nunca houve nada de grave, mas o resto eu acho que é bom.

B3 - Ah, eu acho que não, porque nas salas estamos sempre com as portas fechadas, só os ventiladores ligados e as pessoas sempre falando, então aí circula o mesmo ar e pode pegar alguma doença. Muito lixo na sala (e por que a gente trabalha com a sala fechada?). Porque tem muito barulho.

J1 - Mais ou menos, porque a escola tem rato, coisa suja, fora isso as outras coisas da escola eu gosto.

B1-Ah, eи acho que sim, porque é limpo.

E2 - Eu acho que sim, mesmo porque essa escola não é muito grande, então todo mundo se conhece e também pelo fato da saúde mesmo, eles plantam árvores, tem passarinhos aqui, beija-flor entra na sala. É bem arborizado o local.

G1 - Acho que sim, porque nos somos muito unidos, os alunos, os professores, eles têm um vínculo muito forte.

G2 - Sim, a minha escola tem um ambiente muito saudável, saudável até demais, porque aqui na escola eles não trabalham só com a educação, com o pedagógico, eles trabalham com os sentimentos dos alunos, trabalham com a postura, com o acolhimento, é uma família, uma grande família.

I2 - Sim, temos um jardim e uma área florestal (verde) ótima.

Um ambiente saudável para os alunos deveria ser limpo, sem poluição, sem desmatamento, portanto, com muitas árvores, com boa circulação de ar, organizado, seguro, alegre, com diálogo, respeito, harmonia, amizade, felicidade. Portanto, conforme já relatado, os alunos parecem não perceber o que se passa com o restante do grupo-escola (direção, professores, funcionários), cujos principais problemas relatados se referiam às relações interpessoais, gerando desconforto, insatisfação (e não 
raramente, afastamentos por doenças emocionais), fatores que foram citados como 'de forte influência' no desempenho dos educadores em sala de aula.

e) - Existência de projetos ou ações realizadas para melhorar a qualidade vida na escola:

Poucos alunos relataram a existência de projetos ou ações realizados em suas escolas relacionados à melhoria da qualidade de vida:

$$
\begin{aligned}
& \text { B1 - Não é feito nada. } \\
& \text { B2 - Eu não sei, eu não percebo nada. } \\
& \text { B3 - Não, eu acho que não. } \\
& \text { C1 - Nada, nada, nem projeto, nem nada. }
\end{aligned}
$$

Entretanto, alunos entrevistados dentro de uma mesma escola apresentaram depoimentos conflitantes quanto à existência destes, o que poderia indicar que tais projetos não atingiram o todo da escola ou não tiveram o impacto desejado sobre todos os educandos envolvidos.

A1 - O diretor está fazendo um projeto para melhorar a escola. Ele já começou. Já melhorou um pouquinho a entrada (...) mas ele está fazendo um projeto para tirar o lixo que tem atrás da escola, que a população joga e eles estão querendo colocar um gramado, umas escadas, uma ponte para poder passar de uma rua para outra.

A2 - Nada que eu saiba.

I1 - Nada.

I2 - Temos um jardineiro e um programa anticáries.

I3 - Infelizmente nada.

I4 - Nada.

H1 - Francamente, eu acho que nada.

De qualquer forma, os projetos citados aparecem como "ações pontuais" e específicas de determinadas áreas da escola, como os educadores já haviam descrito: 
D1 - O ano passado nós tivemos um projeto dos professores de Educação Física e Artes, que foi de pintar a escola com a ajuda dos alunos (...). Teve também uma professora de Ciências que fez um jardinzinho numa parte que tem lá embaixo, um canteiro, mas o jardim não foi para frente porque não é uma parte que pega sol, não tem chuva (...)

E2 - Eu acho que esses projetos assim, eles dão mais incentivo quando a gente é da $1^{a}$, $2^{a}$ série para plantar árvores. A gente já plantou, eu lembro na $2^{a}$ série, a gente plantou um Pau-Brasil. E aí a gente viu ela (sic) crescer, só que aí vieram e arrancaram. Além do Pau-Brasil, a gente também plantou girassol (...).

G1 - Era feita a horta, só que a professora se aposentou e vai começar de novo esse projeto com outra professora e novos alunos (...)

G2 - Antigamente tinha o projeto da horta na escola. Eles trabalhavam com a plantação, eles também trabalhavam com o verde em torno da escola e trabalhavam com a saúde também. (...) As frutas e verduras eles comiam, então aquilo fazia toda a escola ensinar e aprender sobre a horta, sobre o meio ambiente, depois entrava a saúde, tinha palestras, tinha a dedicação dos alunos (...) tinha poesia, tudo dentro desse projeto da horta. (...) Agora nossa professora que cuidava do meio ambiente se aposentou (...), mas agora nós podemos resgatar esse projeto para continuar com esse meio ambiente na nossa escola.

J1 - Projeto Beija-Flor. A gente põe plantinhas, põe garrafas em volta para não ir a terra, molha as plantinhas, planta...

J2 - Projeto Beija-Flor e reciclagem. 


\section{3 - ENTREVISTAS COM OS PAIS:}

Assim como ocorreu com os alunos, as entrevistas ocorreram na própria U.E., com horários pré-agendados, seguindo as indicações da Direção, Coordenação Pedagógica ou grupo de professores. No total, foram dez pais participantes da pesquisa, sendo que todas as pessoas eram do sexo feminino (mães). De forma geral, houve uma grande dificuldade em convencer as mães a participarem, pois alegavam falta de tempo ou o despreparo para responder questões sobre educação (houve uma conversa informal com todas antecipadamente, onde foi lido e explicado o Termo de Consentimento Livre e Esclarecido (TCLE) com os objetivos da pesquisa e a descrição das técnicas a serem adotadas em cada caso). Além disso, algumas se mostraram constrangidas pelo uso do gravador, embora tivessem concordado anteriormente com a sua utilização, por isso uma delas solicitou que a pesquisadora enviasse as questões por e-mail para que pudesse fazê-lo de forma escrita.

\section{I - Quanto aos projetos voltados para a cidadania na escola:}

a) - Conhecimento dos pais sobre a existência dos projetos:

Poucas mães responderam positivamente e com segurança quando questionadas sobre a existência de mecanismos de participação dos alunos nas decisões da escola e algumas ainda confundiram "participação na execução" com "participação nas decisões sobre os projetos ou ações". 
Al - Não que eu saiba.

A2 - Nem sempre.

$B 2-N \tilde{a} o$.

$B 3-N a \tilde{o}, n e ́ ?$

D1-Acho que sim.

B1 - Olha, eu acho que sim. Eu sei o que ele me fala, (...) "vai ter tal coisa, mãe, eu vou participar”. Como é a fanfarra (...) e aí eu acho que tem essa iniciativa, sim (...).

E1 - (...) Ele às vezes fala que tem (educação) física, tem francês, tem "não sei o que mais", acho que é leitura, sala de leitura (...) às vezes ele chega tarde e agora ele está sem celular: "L..., o que aconteceu?', "Ah, a professora me segurou e a gente ficou lá com palestra, quer dizer, eles estão sempre aqui decidindo as coisas da escola e ele está sempre no meio.

$J 1-\operatorname{Sim}$

$J 2-N a \tilde{o}$ sei

Os pais demonstraram que em geral, não conheciam os projetos das escolas por isso, falaram superficialmente sobre alguns e às vezes se confundiram com relação aos nomes e ao período em que os mesmos ocorreram:

B1 - Olha, no momento eu não me lembro... Fanfarra, ele participou da Rádio, da fanfarra... Que mais?Isso é que ele participou (...)

Al-Ah, eu nunca vi.

A2 - Desconheço.

J2 - No momento assim, não. Eu sei que ela participa de bastante coisa.

B3 - A Conferência (Infanto-juvenil do meio ambiente).

E1 - É... O xadrez? Passeio, inclusive o Francês realiza passeio todo ano, teatro, tudo isso ocupa muito dele, ele fica muito feliz (...).

$J 1$ - Ah, o projeto Beija-flor, tem as oficinas, as exposições que eles fazem, reciclagem, o agita-galera, que eles adoram (...) ah, eu acho que 
assim, dependendo de cada série, eles fazem projetos bacanas aqui dentro.

Quando questionados especificamente sobre o OP-Criança e as Conferências Infanto-Juvenis do Meio Ambiente, o resultado não foi diferente. Desconheciam ainda, o grau de envolvimento de seus filhos, mesmo quando estes tiveram de fato uma participação ativa, conforme declararam em suas entrevistas, o que, de certa forma indica pouco diálogo e pouco envolvimento dos pais na vida escolar desses filhos...

A2 - Participou do OP. Gostou muito.

D1 - Participou da Conferência.

A1, B1, J1 e J2 - Não participou.

B2 e B3 - Não sei.

E1 - Se participou eu não sei. Ele participa de muita coisa e pra guardar é difícil... Só ele mesmo é que sabe. Se ele estivesse perto de mim, ele diria melhor.

b) - Opinião sobre a importância desses projetos na escola:

Não obstante a maioria dos pais tenha demonstrado desconhecê-los, de forma unânime, estes consideraram importante que as escolas tivessem trabalhos voltados para o desenvolvimento de hábitos saudáveis e para a cidadania.

B1 - Lógico, é muito importante! Aprendendo aqui, ele aprende em casa, ele aprende em todos os lugares. Tem que manter a escola limpa, organizada. $O$ ambiente em que ele vive, ele leva para casa e ele traz de casa, então, eu acho que tudo faz parte do meio ambiente, no meio em que vive. Eu penso assim, é a saúde dele, da escola, de tudo, faz parte, não é?

D1 - Sim, porque ela vai ter uma vida melhor e vai ter uma boa saúde.

D1 - Acho importante para que eles sejam cidadãos mais conscientes. 
c) - Contribuição dos pais para a educação ambiental e desenvolvimento da cidadania dos filhos:

Quase todas as mães afirmaram que procura reforçar os valores e atitudes pró-ativos ao meio ambiente, à saúde e à cidadania em casa, embora tratem desses temas de forma genérica, sem se aprofundarem, pois alguns acreditam que não estão preparados para ensinar sobre isso aos filhos, delegando à escola essa tarefa:

Al - Bom, sobre meio ambiente a gente ensina a não jogar papel no chão, a ser organizada e a saúde, que não ande descalço e que ande sempre agasalhado.

A2 - Tento passar o máximo possível.

B1 - Então, é o que eu acabei de dizer: leva da escola para casa, da casa para a escola: é ter organização, ter limpeza, não só em casa, na rua. Às vezes a gente comenta, por exemplo: "Ah, eu aprendi isso na escola” (...) Aí acontece alguma coisa na TV, então a gente comenta sobre isso, eu falo: "Está vendo? não pode fazer isso! Isso é errado!" (...) Porque a gente vê o fato, aí a gente comenta sobre isso. É difícil às vezes eles mesmos perguntarem e a gente também na correria do dia-adia, (é difícil) falar, mas a gente sempre fala, não é?

D1 - Ah, agora eu não sei... Eu costumo ensinar a ela que nunca jogue as coisas nas vias públicas, nos rios, eu falo para ela: não tendo lugar, guarda na bolsa e em casa joga no lixo, para o bem de todos nós.

E1 - Não, isso aí (meio ambiente) ele estuda sozinho. Ele liga lá a internet e fica lá estudando. Agora, saúde a gente sempre conversa com eles. Está sempre orientando, principalmente porque agora ele é adolescente. $O$ meu marido conversa bastante com ele sobre prevenção, essas coisas, é isso aí que gente fala com ele, agora, pesquisar, aí ele pesquisa sozinho sobre meio ambiente.

d) - Opinião sobre a responsabilidade pelo fracasso dos projetos na escola: 
Atribuem a responsabilidade pela descontinuidade e fracasso dos projetos aos diretores e professores, coincidindo com a visão dos alunos.

A1 - Eu acho que isso vai da direção da escola, porque praticamente todo ano muda a diretoria, eu acho que é por isso que acaba.

A2 - Deveria ter o apoio e a compreensão por parte da direção e dos professores.

B1 - Eu acho que é tomando mais providências com os que trabalham aqui para não deixar acabar, para que melhore cada vez mais, como está acontecendo em outras escolas.

Apenas duas mães citaram os pais (a falta de envolvimento ou colaboração destes) e uma pequena parcela o governo (omissão ou interferência negativa).

B2 - Eu acho que não tem incentivo, nem de um lado e nem de outro (...) então dá a impressão assim, que a escola não tem colaboração de ninguém, ninguém participa, então acaba. Acho que vem lá de cima, por exemplo, a prefeitura quando dá uma verba para aquele projeto, aí a escola chama os pais e ai não tem colaboração (...) Porque hoje em dia essa correria de pais que não vem nem às reuniões, não tem tempo, eu acho que é isso.

E1 - É eu acho que se é importante para os alunos, para a escola também, eu acho que deveria ter ajuda de fora de (onde?) pode ser do Governo, né? Se o governo não ajuda, eu acho que a comunidade pode estar ajudando.

$J 1-E ́$ difícil ... Ah, não digo os políticos, mas a delegacia de ensino, né? Porque é tão bom que a escola tenha projetos culturais, projetos de meio ambiente, porque ensina mais os alunos, e esse negócio de você implantar uma oficina hoje e amanhã já não tem mais, é super chato. Acaba como projeto todo, você não dá continuidade, perde o valor de tudo. Pelo que eu vejo, foi implantando esse pré e pós-aula, tinham que fazer oficinas, mas aí chega na hora, não tem verba, não tem professor, $e$ até falta de vontade das pessoas envolvidas, então, isso tira a vontade dos alunos.

J2 - Eu acho que a população deve exigir que as coisas boas não acabem; que continuem, e mesmo que mude de governo, de partido, que continuem (...) as coisas que dão resultado, que a gente vê (...) que dá certo. 
Vários autores, entre eles SILVEIRA (2000) e ZAGURY (2006) já haviam identificado em suas pesquisas os efeitos prejudiciais da interrupção dos projetos educacionais nas mudanças de governo. No entanto, numa postura "teimosamente individualista e inconseqüente" de parte de alguns políticos deste País, a política não é usada como meio para promover o bem comum e neste caso específico, condena a melhoria da qualidade do ensino público a uma "já eterna sala de espera" da sociedade.

\section{II - Quanto à participação dos pais na escola:}

a) - Forma de participação:

Confirmando as declarações dos professores, as mães responderam que sua participação estava restrita às reuniões de pais e raramente ocorria em outras situações. Apenas uma delas disse não participar de forma alguma.

A1 e B2 - Só em reunião de pais.

B3 - É na reunião de pais e sempre assim, qualquer coisa eu venho na Diretoria me informar e só.

J2 - Nas reuniões de pais e quando tem algum problema, a escola chama.

D1 - Sim, participo de todos os eventos, inclusive do Conselho (de Escola), excursões, organização de festas...

J1 - Eu participo assim: eu sou do Conselho de Escola, estou por dentro dos assuntos que a escola tem, participo também de todo tipo de exposição que a escola faz, festa junina, o que puder eu estou sempre participando, né? Estou sempre por dentro.

A2 - Não.

b) - Incentivo da escola para a participação dos pais: 
Poucas mães disseram nunca terem sido convidadas, mas mesmo assim, afirmaram que nem sempre podiam ir. No entanto, a partir das falas das mães, observou-se que os convites ocorreram para comunicar decisões da Escola.

A1 e B2 - Não. Nunca fui convidada.

J2 - Não, só nas reuniões que eles falam dos trabalhos...

E1 - Convida sim, só que eu é que não participo mesmo. Como o Diretor já falou que ele está à disposição, agora quem quiser vir, que venha só que eu mesma, devido eu ter quatro filhos para cuidar, todos estudando, só o último terminou, (...) pra ser sincera eu não participo não, porque eu não tenho tempo mesmo.

A2 e D1-Sim.

B1- Ah, sim. De vez em quando eles mandam um comunicado que vai acontecer isso ou aquilo e é o que eu falo: tendo horário eu venho (...).

$J 1$ - Ah, acho que sim, porque pelo menos as exposições, as festas, as professoras sempre avisam: "olha nós vamos fazer tal projeto", eles comunicam...

\section{III - Quanto às concepções e percepções sobre a saúde ambiental de cada escola:}

O ambiente escolar de seus filhos foi considerado saudável para a maioria, divergindo da posição dos filhos. Citou-se como fatores preponderantes para isso, a limpeza, a presença de plantas, a ausência de poluição, a organização, o trabalho desenvolvido pela escola. Prevaleceram os fatores físicos sobre os relacionais, também neste caso. Observou-se que, até por estarem pouco próximos do ambiente escolar, os pais de forma geral, discordaram de seus filhos quanto às condições do ambiente físico em que eles estudavam e mais uma vez, não perceberam as questões relacionais que envolviam os profissionais da maioria das escolas e que dizem respeito ao ambiente social da escola. 
A1 - Ah, mais ou menos, pelo que eu vejo, não tem muita limpeza.

A2 - Não totalmente.

B1 - Eu acho que aqui é muito saudável. É muito organizada, é a limpeza, é tudo.

B2 - Olha, mais ou menos, porque numa escola tem todo tipo de gente, como em todos os lugares (...). Em todo canto tem pessoas que a gente não conhece o coração, então posso dizer que mais ou menos, mas pelo menos aqueles que ela (a filha) tem procurado fazer amizade são pessoas que a gente pode confiar. (Quanto aos aspectos físicos) $E$ um ambiente limpo, um ambiente bem cuidado, a gente vê que os professores, a parte humana, a parte do trabalho, os próprios funcionários da escola procuram manter tudo limpo, tudo organizado, eu acho bacana.

B3 - Em vista de muitas escolas que eu conheço, essa é uma das melhores, das escolas publicas, é limpa, é bem conservada.

E1 - Ah, eu acho que aqui é um ambiente saudável prá ele (o filho), devido às atividades que ele faz: tem educação física, tem... Eu acho que é só isso. 


\section{4-QUESTIONÁRIOS COM AS EQUIPES TÉCNICAS:}

Por estar presente no universo escolar há muito tempo, a pesquisadora já previa algumas das dificuldades apresentadas, como: deficiências na organização de algumas escolas e equipes técnicas freqüentemente sobrecarregadas com papéis e afazeres administrativos (demandas dos órgãos dirigentes). Nesse cenário, existem possibilidades consideráveis de extravio de documentos e sobra-se pouco tempo para outras atividades, especialmente as pedagógicas inerentes à função desses educadores. A rotatividade dos ocupantes desses cargos na Rede, também poderiam ter influenciado em algumas situações descritas, pois em parte das escolas, os participantes haviam chegado há pouco tempo, não conheciam ou não tiveram acesso às informações requeridas sobre períodos anteriores à sua chegada à UE. Esses fatores isolados ou conjugados podem explicar, em parte, a perda de vários questionários, os dados incompletos e o fato dos participantes não terem priorizado o preenchimento e a devolução dos mesmos.

Somente duas das seis escolas cujos questionários retornaram, colocaram à disposição todos os dados solicitados, as demais o fizeram de forma parcial, impossibilitando a utilização desse instrumento de pesquisa com a amplitude que se desejava. Em função da deficiência de informações, o item I - "Dados das Escolas", relativos ao número de turnos, de classes, de alunos e do rendimento escolar no período de 2001 a 2006, foram desprezados nesta análise. Tencionava-se analisar o número de alunos atingidos pelos projetos estudados e a possível relação destes com o rendimento escolar, o que não foi possível fazer. 


\section{II - Quanto às informações sobre o cargo, a formação e tempo de trabalho na escola:}

Os participantes foram os Coordenadores Pedagógicos e em apenas uma das escolas foi o Assistente de Direção.

Somente em duas das escolas, esse integrante de equipe técnica era formado apenas em Pedagogia, os demais, tinham além desta, a formação em disciplinas das áreas de humanas, exatas ou biológicas. Todos tinham também, experiência como professores de sala de aula, as duas primeiras no ensino fundamental I e os demais em suas disciplinas específicas no ensino fundamental II, aspecto importante, pois já vivenciaram a realidade da sala de aula enfrentada pelos professores.

Em apenas três das escolas esse educador estava na Unidade há menos de cinco anos e afirmara conhecer pouco a realidade da escola. Nas demais, esse período estava entre cinco e dez anos ou mais, tempo suficiente para conhecer e poder interferir com propriedade nos problemas detectados.

\section{III - Problemas da escola e busca de soluções:}

Os problemas de aprendizagem se sobressaíram na lista apresentada pelos participantes, embora os de gestão tenham acompanhado as respostas em mais da metade delas, conforme se pode evidenciar abaixo:

(B) Gestão - equipe técnica incompleta, mudanças constantes de direção. Aprendizagem - defasagem na leitura e escrita.

(C) Gestão - poucos funcionários e falta de professores substitutos. Aprendizagem - classes numerosas, professores que adoecem e faltam.

(G) Gestão - falta abertura, mais democratização nas decisões, participação mais efetiva.

Aprendizagem - alunos com problemas de leitura e escrita no Ciclo

(J) Gestão - falta uma equipe mais coesa, isto é, o diretor e o CP são novos na U.E. e estão em fase de adaptação;Faltam professores eventuais. 
Aprendizagem: alunos com muitas dificuldades cognitivas, desmotivados pela família/social/falhas no sistema educacional.

(H) Aprendizagem - falta de interesse e acompanhamento dos responsáveis pelos alunos.

(E) Aprendizagem - não especificou quais.

É interessante observar que, na escola $G$, onde os problemas de gestão estão relacionados à falta de participação e abertura democrática para tal, poucos professores se reportaram a esse aspecto no grupo focal, embora tivessem tido a liberdade de fazêlo, já que não havia nenhum integrante da equipe técnica presente naquele momento que pudesse intimidá-los de alguma forma. Este era um cenário esperado pela própria pesquisadora, que já atuara em anos anteriores na escola e que teve, inclusive, a autorização para fazer a pesquisa questionada pela Direção, mesmo após apresentar os documentos da Secretaria de Educação que permitiam fazê-lo. No entanto, essa questão também não apareceu nas falas dos alunos entrevistados, o que poderia indicar receio ou acomodação de todos diante do problema, que é real e inclusive conhecido por comunidades de escolas próximas. Assim como na escola B, como foi anteriormente mencionado, a Coordenadoria de Ensino, precisou intervir, mas especificamente neste caso, a responsável pela direção da escola foi afastada para garantir o seu bom funcionamento.

Enquanto para a escola B a busca de soluções veio em forma de cursos de formação, citados pela Coordenadora e direcionados à equipe técnica e docente, ligados à questão de aprendizagem e também à de gestão, nas demais escolas os problemas eram discutidos com os educadores nos horários de JEI (C, E, G e H) e culminaram em aulas de recuperação paralela e orientação de alunos e pais, quanto ao acompanhamento das tarefas dos filhos (escola C). Portanto, verificou-se que, na maioria dessas escolas não havia de fato, a cultura de envolver os pais nos processos de discussão e de busca de soluções dos problemas que surgem no cotidiano das escolas, sejam eles de aprendizagem ou de gestão, não obstante estes estejam imbricados e reflitam diretamente na qualidade de ensino oferecida pela escola. Esta é uma tarefa que deveria ser liderada pelas equipes técnicas, responsáveis pela gestão escolar e também pela orientação pedagógica do corpo docente. 


\section{IV - Quanto ao oferecimento, participação e opinião sobre os cursos} da Rede no período de 2000 a 2005 :

Todos os participantes responderam afirmativamente quanto ao oferecimento pela Rede, de cursos para as equipes técnicas no período destacado, tanto voltados à formação pedagógica, quanto à gestão escolar.

Entre esses cursos, os mais citados foram: PROFA (Projeto de Alfabetização, Letramento, Visão de Mundo e Inclusão), Projeto Ler e Escrever, TOF (Toda a força no $1^{\circ}$ ano), Protagonismo Infanto-Juvenil, DST (Doenças Sexualmente Transmissíveis), ABC na Educação Científica - Mão na Massa, Orçamento Participativo, Orçamento Participativo Criança, MOVA (Movimento de Alfabetização), Programa Círculo de Leitura, Vivências Culturais, CRECE (Conselho Regional de Conselhos de Escola formação para integrantes), Recreio nas Férias (formação para coordenadores e oficineiros), Educom.rádio, Dança e Música da Cultura Popular, Gestão Escolar, Formação para Coordenadores Pedagógicos e Formação para o Trio Gestor (Diretor, Assistente de Direção e Coordenadores Pedagógicos).

Observou-se que dos cursos citados, apenas quatro foram oferecidos na atual gestão (2005-2008), os demais se referiam à gestão anterior.

Quanto à participação desses integrantes em algum desses cursos de formação, observou-se que na maioria das escolas, houve uma participação privilegiada nos cursos relacionados à alfabetização, leitura e escrita (PROFA, Ler e Escrever, TOF, MOVA, Circulo de Leituras). Apenas na escola C, a Coordenadora teve uma formação diversificada, importante para quem tem a missão de orientar o processo de construção e implementação do PPP da Escola, promovendo a participação e a integração do grupo docente, funcionários, pais e alunos nos diferentes projetos e ações.

Os depoimentos a seguir serão identificados apenas pela letra correspondente à escola da qual o membro da equipe técnica participante faz parte: 
(B) - Sim. PROFA, Projeto Ler e Escrever, TOF.

(C) - Sim. PROFA, Protagonismo Infanto-Juvenil, DST, ABC na Educação Científica-Mão na Massa, Orçamento Participativo, Orçamento Participativo Criança, MOVA, Programa Circulo de Leitura, Vivências Culturais, CRECE, Recreio nas Férias, Educom.Rádio, Dança e Música da Cultura Popular.

(E) - Sim. Projeto Ler e Escrever, PROFA, Formação para Coordenadores Pedagógicos.

$(G)$ - Sim. Formação para Coordenadores Pedagógicos, Formação para o Trio Gestor, PROFA.

(H) - Sim. Formação de Equipe Técnica (Trio Gestor).

No tocante à opinião sobre os cursos dos quais esses educadores participaram, houve unanimidade quanto à necessidade dos mesmos. De maneira geral, os mais bem avaliados estavam relacionados à leitura e escrita, que é o maior problema relacionado à aprendizagem relatado pela maioria das escolas e principal foco da Secretaria Municipal de Educação na atualidade.

\section{V - Sobre projetos de protagonismo infanto-juvenil no período de 2000 a 2005:}

a) - Conhecimento sobre projetos existentes nesse período e opinião sobre os mesmos:

Todos os entrevistados citaram projetos ocorridos nesse período, como: OPCriança, Educom.Rádio, Conferências Infanto-Juvenis do Meio Ambiente, Vamos Combinar, Grêmio Estudantil, destacando a importância e algumas limitações dos mesmos para os alunos: 
(B) - O OP.Criança: A criança fazia o levantamento de prioridades da comunidade escolar e do entorno e buscava encaminhamentos.

(C) - O OP.Criança: Observei uma diferença em relação às crianças que participaram.

(E) - O OP.Criança: faltou, porém uma devolutiva do trabalho realizado nas escola $(*)$ O $O$ Educom.Rádio em 2004 foi desenvolvido satisfatoriamente, porém os alunos participantes saíram da escola, bem como os professores multiplicadores. Com a mudança de governo, perdemos também as orientações técnicas e apoio no desenvolvimento dos projetos.

(*) A devolutiva foi feita no final da gestão em 2004, através de um livro publicado pelo Instituto Paulo Freire, parceiro de SME: “Orçamento Participativo-Criança: exercendo a cidadania desde a infância" que foi distribuído para todas as escolas da Rede e em muitas Unidades foi esquecido nas Salas de Leitura. Não houve um momento destinado à leitura e discussão do mesmo durante os horários coletivos de estudo ou reuniões pedagógicas naquele mesmo ano ou nos anos seguintes, por isso, para a maioria dos educadores e alunos, a prestação de contas do projeto, ou seja, a divulgação dos resultados passou despercebida.

(G) - Educom.Rádio e Grêmio foram muito bons.

(H) - Esses projetos promovem a integração entre os alunos e podem abrir um novo olhar.

b) - Participação da escola nas duas versões do OP-Criança:

Com exceção da escola G, cuja Coordenadora Pedagógica havia chegado recentemente àquela escola e, portanto, não detinha informações a respeito, todas as demais afirmaram que suas escolas participaram das duas versões do OP-Criança (2003 e 2004).

c) - Participação da escola nas duas versões da Conferência Infanto-Juvenil do Meio Ambiente e no Seminário de preparação da segunda versão: 
Já com relação às Conferências Infanto-Juvenis do Meio Ambiente, na primeira versão (2003), apenas três escolas tiveram participação (E, H e J), sendo que na segunda versão (2005), somente a Coordenadora da Escola G disse não ter informações sobre esse processo, as demais confirmaram a participação e assinalaram também a presença no Seminário para a preparação da Segunda Conferência, destinado às equipes técnicas, professores, funcionários e alunos, em Novembro de 2004.

Uma observação particular sobre esse Seminário merece ser destacada, uma vez que a responsabilidade pelo convite às escolas estava a cargo da pesquisadora, à época, trabalhando na Coordenadoria de Educação de Itaquera: Ao receber o convite, muitas escolas justificaram a sua ausência por estar no final daquela gestão, que já se sabia não teria continuidade (o segundo turno das eleições já indicara a vitória de outro partido político) e, portanto, elas entendiam que não precisariam mais atender às orientações das Coordenadorias e nem deveriam mais se comprometer com qualquer projeto daquela gestão, muito embora, as Conferências fossem de competência do MEC/MMA, de gestão federal e assim, teriam continuidade independente da gestão municipal. Isso demonstra que as escolas muitas vezes deixam de se sentir comprometidas com determinados projetos da administração, ainda que estes sejam relevantes e possam trazer contribuições importantes, sempre que ocorre mudança de governo, acostumadas que estão, ao desmantelamento das políticas educacionais e conseqüentemente de prioridades e projetos, cada vez que há rodízio de partidos no poder.

\section{d) - Desdobramentos do OP-Criança e das CIJMA nas escolas:}

Sobre a transformação desses projetos em ações concretas na escola, com exceção da escola $\mathrm{E}$, que afirmou que o que foi definido nas Conferências pelos alunos como prioridades a serem desenvolvidas, não se concretizou na escola, ainda que o processo tenha contribuído significativamente para o protagonismo dos mesmos, as demais indicaram a ampliação de projetos de meio ambiente $(\mathrm{B}, \mathrm{C}$ e J), do Grêmio e do Educom.Rádio em suas Unidades ( $\mathrm{G}$ e $\mathrm{H})$. 
e) - Facilitadores e dificultadores para desenvolver e dar continuidade a esses projetos na escola:

As Coordenadoras Pedagógicas das escolas B, G e J consideraram como facilitadores para o desenvolvimento e continuidade desses projetos na escola:

(B) - A participação no OP deu maior incentivo ao grêmio estudantil. O projeto de Meio Ambiente recebeu maior motivação com a participação dos alunos na II Conferência Infanto-Juvenil do Meio Ambiente.

(G) - (Facilitou): formação com especialistas, a aparelhagem (Rádio) fornecida às escolas, envolvimento dos participantes.

$(J)$ - Achamos que o projeto (O.P.) ia de encontro às necessidades dos alunos.

Com exceção da escola J, E e H, as demais não citaram dificultadores. As três escolas indicaram como motivos que dificultaram ou impediram :

(E) - A mudança de governo, mudança na equipe da Unidade Escolar.

(H) - No Grêmio faltou interesse, tanto por parte dos discentes quanto dos docentes.

(J) - Quando termina uma gestão, isto é, muda a política, os projetos acabam sendo abandonados ou são reformulados e trocam-se os nomes.

A escola $C$ não se pronunciou a respeito. 


\section{VI - Agenda 21 e Agenda 21 Escolar:}

a) - Conhecimento das equipes técnicas sobre esses documentos e opiniões sobre eles:

Todas as UEs afirmaram conhecer a Agenda 21 e os meios de informação foram: jornais, internet, cursos promovidos pela Coordenadoria, textos pedagógicos e ao se darem as suas opiniões sobre ela, demonstraram conhecer os seus objetivos:

(B) - Opinião favorável, pois devemos preservar o meio ambiente, favorecendo o 'equilíbrio do aquecimento global'.

(C) - É o inicio da consciência planetária, mas com muita dificuldade de ser implantada porque a desigualdade social, a fome, etc, ainda é grande.

(E) - É um documento que visa a união dos povos para proteger o meio ambiente e cada país estabeleceu suas metas para proteção do planeta Terra. É preciso um rigor maior para que realmente haja a proteção do planeta.

(G) - Muito importante para a conscientização e formação dos cidadãos.

(H) - É um projeto ótimo desde que haja integração com outros órgãos.

b) - Existência de uma Agenda 21 Escolar na Unidade:

De acordo com os integrantes das escolas C, E, G, H e J afirmaram que não há uma Agenda 21 Escolar em suas Unidades, apenas na Escola B a discussão e algumas ações estavam se iniciando (pelas mãos de uma única professora que tentava cumprir o papel da Coordenação Pedagógica, ausente também nesse processo. Isso justifica o fato dessa informação não ter aparecido no grupo focal realizado com os professores). A própria Coordenadora explicou, desresponsabilizando-se, que esse processo está a cargo de uma professora de Ciências e seus alunos, portanto, restrita a uma disciplina e alguns discentes apenas. 
$\mathrm{Na}$ escola $\mathrm{E}$, as informações prestadas pela equipe técnica e grupo de professores, coincidem, pois estes últimos afirmaram que haviam iniciado uma Agenda 21 Escolar, porém precisavam de mais subsídios teóricos para dar continuidade à ela e as Coordenadoras afirmaram que já haviam alguns encaminhamentos em 2005 e 2006, mas estavam na expectativa da elaboração e implantação em 2007.

c) - Percepção acerca da saúde ambiental da escola:

Na visão da maioria desses integrantes de equipe técnica, as suas escolas possuem um ambiente saudável:

(B) - Sim. Temos buscado conscientizar para que o meio ambiente se torne cada vez melhor.

(E) - Sim. Tem muitas árvores, é bem arborizada.

Levando em consideração os depoimentos já apresentados dos professores e alunos das escolas B e C, é possível identificar discordâncias entre estes e as posições de suas respectivas equipes técnicas, pois para os primeiros, o ambiente escolar não é saudável. Essa constatação acerca do 'olhar' divergente das equipes técnicas em relação aos outros segmentos da comunidade escolar, certamente colabora para agravar os quadros descritos pelos professores e alunos e para que os órgãos técnicos ligados à SME também não identifiquem como relevantes esses aspectos da saúde ambiental nas escolas, já que a interlocução Escola-Coordenadoria-SME fica normalmente a cargo das equipes técnicas, que deveriam conhecer e representar as posições do grupo-escola, mas nem sempre o fazem. Pensando-se na construção de uma educação verdadeiramente democrática em nossa Cidade, essa forma de intermediação poderia ser superada e isso colaboraria certamente para que os problemas que afetam as comunidades escolares fossem resolvidos de maneira mais rápida e eficaz.

(C) - Sim. O espaço físico é muito interessante e organizado e a concepção deste prédio também. Trabalhamos pela democratização do acesso, inclusão dos portadores de necessidades especiais. 
(G) - Sim. Limpeza, não é muito pichada, bons relacionamentos, com poucas exceções. Pouco vandalismo e destruição do patrimônio da escola.

Somente as Escolas C e $\mathrm{G}$ destacaram outros fatores, além dos físicos, para classificar o ambiente escolar como saudável.

Para as Coordenadoras Pedagógicas das escola $\mathrm{H}$ e J, não há ambiente saudável na sua escola, posição que, neste caso, coincide com a dos alunos e professores.

(H) - Não. A estrutura da escola colabora para vários fatores, como sons em exagero que dificulta as aulas e outros.

(J) - Não de forma satisfatória, pois temos vários itens a melhorar.

d) - Como melhorar a saúde do ambiente escolar:

As sugestões para tornar o ambiente escolar mais saudável levaram em consideração

(B) - Projetos voltados à construção de um melhor posicionamento frente ao meio ambiente e a sua preservação. Ações diárias - coleta seletiva - Agenda estudantil (Agenda 21 escolar)

(C) - não respondeu.

(E) - Um projeto que vise conscientizar cada pai, aluno, professor $e$ funcionário sobre a importância e a urgência da defesa do meio ambiente, com ações práticas.

$(G)$ - Despertar o amor e o cuidado com a escola. Maior participação dos pais na vida escolar dos filhos. Conscientização de que todos são educadores.

(H) - Uma reforma urgente. 
e) - Fatores que contribuiriam para implantar as ações e projetos sugeridos pelas equipes técnicas:

Para esses educadores o que facilitaria esse processo seria:

(B) - Conscientização de todos os envolvidos com relação à importância dos projetos, realizando palestras, visitas, pesquisas, etc.

(E) - A escola tem que priorizar esse tema, abraçar esse projeto, fazer parte do currículo.

(G) - Mais reuniões com os pais, para compartilhar os problemas e as soluções da escola.

(J) - A efetivação do Projeto da nossa escola: Beija-Flor.

Observou-se que na escola $\mathrm{G}$, a responsabilidade pelo sucesso ou fracasso das ações pedagógicas foi colocada de forma enfática também nas mãos dos pais e a Coordenadora mostrou o interesse em desenvolver mecanismos para que essa participação fosse efetiva em todas as etapas da resolução dos problemas que surgem na escola, assim como na escola E.

Na escola B, embora a Coordenadora se refira a "todos os envolvidos", esse segmento não é destacado de forma especial e, além disso, a sua própria responsabilidade, sabidamente negligenciada nessa escola parece ser minimizada por ela. Nas demais escolas o papel dos pais sequer foi citado. 


\section{V - CONCLUSÕES}

Levando em consideração aos resultados obtidos a partir dos três instrumentos metodológicos utilizados e analisados de forma complementar, pode-se afirmar que, tanto no campo das discussões, como no campo das ações, a educação ambiental dentro da concepção histórica eleita por esse trabalho e a democracia participativa envolvendo o protagonismo dos alunos, estão ainda em um estágio pouco evoluído nesses cenários, mesmo quando aparecerem no PPP das escolas. Portanto, não têm o efeito desejado sobre os currículos no sentido de torná-los emancipatórios, conforme a descrição feita na introdução desse trabalho, nem tampouco de empoderar os alunos ou melhorar a qualidade de vida daquelas comunidades escolares. Apenas uma pequena parcela dessas Unidades têm tido a preocupação de transformar o seu currículo e construir um ambiente saudável e mesmo assim, enfrentam dificuldades de ordem técnica, organizacional e também ideológica dentro e fora da escola.

Há um consenso entre professores, pais e alunos sobre a importância da educação ambiental escolar, do protagonismo dos alunos e da necessidade de criar canais de participação mais democráticos dentro das escolas, mas ocorreram divergências quanto ao papel específico de cada um dentro do processo educativo, bem como da interferência governamental na esfera escolar, o que comprova que ainda há muito que fazer para promover a transição entre a chamada 'consciência ingênua' e a 'consciência crítica' dentro dessas comunidades e essa, embora seja a principal missão da educação emancipatória, parece não ter sido reconhecida e despertada no seio da maioria dessas escolas.

As discordâncias persistiram na percepção da influência de fatores externos ao lócus escolar sobre o fracasso ou sucesso dos projetos pedagógicos desenvolvidos. Conforme foi discutido, a responsabilidade do Estado dilui-se nas esferas mais próximas à população, neste caso representada pelos alunos e pais, usuários da escola, o que é próprio de um contexto político e econômico onde prevalece a lógica neoliberal, lembrando as discussões postas por vários autores na introdução desse trabalho. Sendo 
assim, 'sobra' para os professores e equipe gestora, todos os ônus decorrentes da ineficiência da educação oferecida, quando na verdade, a população deveria estar fiscalizando e reivindicando das autoridades governamentais o cumprimento do seu papel de administradores, formuladores e implementadores de políticas públicas. Conforme foi discutido anteriormente, não é possível creditar exclusivamente aos educadores todas as mazelas da educação, enquanto os responsáveis pelo sistema educacional saem ilesos desse julgamento, justamente eles, que coordenam as reformas educacionais, organizam e controlam os recursos das Redes de Ensino e os processos de formação de seus profissionais.

Por outro lado, também entre os educadores, apesar de terem consciência sobre o papel e o desempenho de cada setor nos resultados finais das ações pedagógicas, ao que tudo indica, muitos foram tomados pelo desânimo e alguns pela alienação e assim, poucos se dispõem a enfrentar as situações adversas por eles descritas e lutar por um cenário mais favorável para a educação, principalmente com esse caráter emancipador. Não é de se estranhar que dentro do universo pesquisado, somente a minoria dos educadores possui ou já possuiu engajamento com alguma causa social ou política, o que é preocupante, uma vez que ninguém pode convencer o outro daquilo que nem mesmo ele acredita. Falta, para muitos, a consciência política, o exercício concreto da cidadania no seu dia-a-dia, o inconformismo e a 'inquietação cinética' que vence a inércia e dispõe o indivíduo para a conquista do objetivo perseguido.

Assim, 'a discordância' e 'o protesto' contra o status quo em que se encontra a educação e a própria sociedade, ficam restritos ao plano dos discursos ou ainda na opção silenciosa e resignada de se fechar na sala de aula e assumir o fracasso, já que o que costuma vigorar na maioria dessas escolas é a reprodução acrítica de uma educação bancária, por meio de um currículo tradicional e de práticas conservadoras. Em alguns casos convivem lado a lado com o 'novo', representado por iniciativas isoladas de alguns professores, que configuram a 'resistência' e a 'esperança'. Conforme foi descrito, as concepções dos educadores dentro de um mesmo grupo, não são uniformes e em alguns casos, geram conflitos. Porém, encontrou-se também, a coexistência velada dessas práticas contraditórias dentro das escolas, prevalecendo o princípio do 'cada um faz do seu jeito', sem que as equipes técnicas tivessem a preocupação pedagógica de avaliar e evitar os impactos negativos dessas contradições sobre um mesmo grupo de 
educandos. Portanto, esses atores estão negligenciando o seu papel de direção e coordenação pedagógica. Observou-se que em escolas onde a equipe técnica era mais compromissada e parceira na condução do trabalho pedagógico da escola, os educadores se sentiam mais satisfeitos, respaldados e os projetos caminhavam com maior sucesso. Certamente encontraram o caminho para construir o 'sujeito coletivo', superando as rupturas promovidas pelo choque de identidades e interesses inerente a diversos espaços de interação social como é o caso da escola.

Embora os objetivos dos Projetos Políticos Pedagógicos e dos Planos de Ensino, segundo relato dos próprios educadores, estivessem focados na construção de uma cidadania ativa dos alunos, os professores demonstraram que prevalece a lógica da transmissão de conhecimento e de valores a partir de 'conversas informais', atividades pontuais e desconexas do PPP, supondo-se que estes poderiam ser automaticamente incorporados às atitudes dos alunos e em curto espaço de tempo. Há, ainda, a personalização dos projetos existentes em algumas UEs, onde professores trabalham isoladamente e experimentam a frustração de constatarem o pouco alcance de suas ações, apesar de seu esforço, ou a necessidade de abandoná-los no meio do caminho, quando se aposentam, mudam de escola ou troca-se a gestão política. Poucos professores reconhecem, ainda na educação ambiental, um poderoso instrumento para formar os alunos dentro do perfil que eles mesmos denominam de 'clichê na educação': crítico, participativo, responsável, feliz... Normalmente, cabe ao professor de Ciências a tarefa de desenvolver as atividades e os projetos de EA. Portanto, na concepção geral, a educação ambiental está identificada apenas com a transmissão de conteúdos sobre ecologia, assunto que para eles, é específico da área de Ciências. Em raras situações, tanto nos momentos de formação dos educadores, os problemas socioambientais foram discutidos levando em consideração todas as suas dimensões que envolvem as questões políticas, sociais, econômicas, culturais... Por isso as deficiências dessa forma de abordagem são visíveis na prática dos educadores.

O estigma de ' conservador' não agrada a nenhum professor, mesmo quando ele realmente o é e neste caso, muitos deles justificaram sua resistência em adotar 'novos currículos e metodologias' pela dificuldade em se desvincular dos formais, uma vez que para eles, essa escolha significava a segurança em relação ao que sempre fizeram. Não apenas nesses cenários, mas também em outros, muitos pais coadunam-se com essa 
posição e acreditam na eficácia desse modelo pedagógico, pois reagem negativamente quando seus filhos saem da sala de aula convencional para vivenciarem novas experiências educativas. Falta, nesse caso, um trabalho formativo sistemático, consistente e bem orientando no sentido de auxiliar educadores e pais na escolha de uma concepção pedagógica coerente com os anseios e necessidades expressos em seu PPP. Inclusive sobre esse documento cabe ressaltar que em parte considerável das escolas os educadores demonstraram compreender pouco sobre os mecanismos que regem a construção do PPP, o seu conteúdo e sua real e importante função de nortear o trabalho pedagógico para que a escola cumpra o seu papel.

Assim, esse documento é muitas vezes elaborado por um ou outro membro da equipe técnica, geralmente os coordenadores pedagógicos ou com a participação simbólica ou fictícia de alguns professores, como se fosse apenas mais uma obrigação burocrática a ser cumprida, aprovada pela Coordenadoria de Educação e depois esquecida no fundo de um armário da escola, tornando o acesso a ele bastante complicado. Mesmo em escolas onde os professores declararam participar de sua elaboração, ficou demonstrado que raramente recorriam a ele no momento de pensarem nos seus planos de trabalho e os profissionais que chegaram depois desse processo à Unidade Escolar também não tinham a iniciativa de fazê-lo. Essa cultura torna-o, portanto, um instrumento inerte dentro da dinâmica pedagógica da escola, que segue 'atirando para todos os lados' sem saber ao certo, ou o alvo que deseja atingir ou como pretende fazê-lo.

A pesquisa mostrou também que uma parte significativa daqueles docentes encontrava-se desmotivada profissionalmente e muitos demonstraram, inclusive, um verdadeiro estado de exaustão. Contribuíram para isso, as condições desfavoráveis de trabalho em todos os campos: estrutural, financeiro, pedagógico e das relações sociais entre os membros da comunidade escolar.

O despreparo e a solidão para realizar os fazeres pedagógicos nas escolas são, indubitavelmente, determinantes na inviabilização de um projeto de escola mais eficiente, democrática, cidadã e saudável. De fato, os educadores carecem de condições de trabalho adequadas, que vão desde fatores físico-estruturais, financeiros, emocionais, ao apoio pedagógico, neste caso representado pela falta de subsídios teóricos e práticos 
para incrementarem suas aulas e de parcerias fundamentais, como o apoio da equipe técnica, de colegas e dos pais, conforme já foi citado. Mas entre eles foi possível encontrar ainda, aqueles que encontravam motivação na crença de que 'a utopia' não é irrealizável. Não é de se admirar que estes profissionais não se intimidassem diante das mesmas condições de trabalho que a muitos desanimam e expressassem alegria e esperança, 'combustíveis' necessários para um ofício como esse.

Os sindicatos da categoria já não são mais identificados pelos educadores aqui representados como um espaço de formação técnica e política. Tampouco considerados eficientes na luta para melhoria das condições de trabalho e da qualidade da educação e de vida na escola, embora às vezes, falte aos educadores a visão de que o sindicato é constituído por eles próprios e não apenas pelos seus dirigentes, por isso sua ação passa primeiro pelas mãos dos próprios educadores que o sustentam.

O protagonismo dos alunos é uma questão que demonstrou sensibilizar a maioria dos educadores, pais e alunos, mas não a ponto de movê-los para ações concretas nessa direção. Alguns educadores confessaram que se sentiam desconfortáveis com a movimentação dos alunos no espaço escolar e com a agitação provocada por certos projetos, comportamento designado por eles de "bagunça generalizada". O medo de perder o controle sobre os alunos e sobre a situação de aprendizagem é o que costumava restringir a possibilidade de investimento no protagonismo infanto-juvenil nas escolas. Mais uma vez, a falta de uma consciência clara dos educadores sobre a sua própria concepção pedagógica tem alimentado a dissonância entre seus objetivos e a suas práticas.

Por outro lado, a resistência dos alunos a esse modelo autoritário de educação acabou sendo entendida como 'rebeldia', 'indisciplina', 'desinteresse', mas na verdade, endossou o que já foi discutido anteriormente: os alunos não concordavam com 'o fazer para eles, mas 'sem eles', a exemplo da escola que compreendeu a importância de construir um ambiente saudável, mas afirmou estar elaborando uma Agenda 21 Escolar, sem a participação dos alunos, pais e outros segmentos daquela comunidade. De forma especial, alunos que experimentaram, ainda que por pouco tempo, o exercício do poder compartilhado e conheceram de perto os empecilhos que são impostos por aqueles que insistem em manter os privilégios que a centralização do poder lhes confere, 
demonstraram que aprenderam importantes lições para suas vidas e desenvolveram capacidades e valores paradoxalmente 'tão desejados' pelos seus mestres: consciência critica, disposição para o diálogo e para a negociação, poder de argumentação, autonomia, responsabilidade, capacidade de luta e de resistência. Somente os educadores que participaram concretamente desse processo através de projetos como, por exemplo, o OP-Criança e as Conferências Infanto-Juvenis descritos nesse trabalho, compartilharam da alegria de protagonizarem com seus alunos uma experiência tão rica e gratificante de educação emancipadora e compreenderam o significado da expressão educar para o protagonismo, mas sendo um "adulto de passagem ligeira".

Quanto aos pais, o pouco ou nenhum envolvimento destes nos diferentes momentos da vida escolar de seus filhos, mostrou que, de forma similar ao que ocorre com os alunos, faltam mecanismos mais atraentes para tal participação nas Unidades Escolares. Estas, por outro lado, ao mesmo tempo em que cobram uma presença mais efetiva desse segmento no seu cotidiano, não têm construído espaços democráticos onde caiba a participação não figurativa, que normalmente se resume a ratificação de decisões já tomadas pelo gestor da escola ou pelos próprios professores.

Porém, também é verdade que nas raras situações em que a escola optou por uma linha pedagógica inovadora, a visão conservadora de alguns pais de que o trabalho do professor deveria ser feito à sós com seus alunos e de preferência dentro das quatro paredes da sala de aula, contrariou e desestimulou os professores envolvidos, dificultando as possibilidades de intercâmbio de saberes e a revisão dos poderes dentro do espaço escolar, forçando um retrocesso para estágios que já haviam sido 'durante vencidos' na superação de uma educação conservadora dentro desses espaços.

Ficou claro que as mudanças de gestão às quais foram submetidas as escolas acabaram resultando em mudanças na concepção de educação e inversão de prioridades, desconsiderando os caminhos e avanços já conquistados pelas escolas - ao que poderia ser designado de 'políticas vacilantes', inspirando-se no termo 'situação vacilante' utilizado por um educador para definir o papel da escola atual, que ora vai para trás, ora para frente e os educadores, educandos e pais que nem sequer costumam ser consultados, acabam se vendo diante desse dilema que, muitas vezes nem conseguem decifrar, quanto mais resolver. É evidente que algumas iniciativas cumprem uma única 
função: a de dar maior visibilidade política à gestão desse ou daquele partido político que assume o poder.

Provavelmente por causa disso, identificou-se, uma 'desacreditação latente' entre esses profissionais quanto às intervenções do poder público no sentido de democratizar a gestão e melhorar a qualidade de vida da população, incluindo no campo educacional, mas apesar disso, poucos educadores têm tido disposição para atuar em outras esferas sociais, no local onde vivem ou atuam profissionalmente, para promover as transformações políticas e sociais necessárias. A observação de parte desses profissionais fora do cenário dessa pesquisa, no curso sobre cidadania promovido pela USP-Leste e Organizações Populares, foi importante para perceber que há uma verdadeira acomodação ou até aversão por parte de alguns deles pelas questões de ordem política e de ativismo social, fatores que foram determinantes no abandono do curso antes da sua conclusão.

Pode-se ainda, concluir, que os 'olhares' e as 'perspectivas' dos diferentes atores sociais envolvidos nas escolas, sobre como deve ser um processo educativo fundamentado nos princípios de emancipação dos sujeitos, sobre a importância da democracia participativa, do empowerment dos alunos e da necessária busca e garantia da saudabilidade do ambiente escolar para toda a sua comunidade, de forma geral, não foram devidamente considerados nos contextos analisados. Essa situação indicou que houve pouca disposição para o diálogo e para o compartilhamento de poderes e responsabilidades, além de oportunidades para a necessária reflexão filosófica proposta por SANTOS NETO sobre as concepções antropológicas, gnosiológicas e políticas que permeiam as concepções e as práticas pedagógicas. 


\section{VI - CONSIDERAÇÕES FINAIS}

Algumas medidas poderiam ser encaminhadas com vistas a suprir ou pelo menos diminuir as dificuldades apresentadas pela maioria das escolas pesquisadas, possibilitando que estas exerçam, de maneira mais eficaz, o seu papel de produtoras de conhecimentos, de valores, de cultura, de saúde e de felicidade.

É imperativo que se pense num modelo de formação mais abrangente, superando a lógica do "professor multiplicador", já que, na maioria dos casos, essa formação é dada fora do horário de trabalho do professor e do espaço escolar e quando este retorna à Unidade Escolar, não dispõe dos recursos necessários para apresentar aos demais aquilo que ele aprendeu, seja do ponto de vista do apoio logístico, que deveria receber da equipe técnica ou mesmo da disposição e disponibilidade dos demais colegas de participarem daquele momento de formação. Além disso, há coerência na fala do professor quando justificou as limitações desse modelo porque "experiência não se multiplica - você vive ou não vive". Por isso, há que se pensar em uma forma de tornar a formação permanente do docente mais acessível e, portanto, mais includente, inserindo-a no lócus e na rotina escolar, valorizando a realidade, os atores e as culturas já construídas e resignificando os horários de estudo coletivos, momentos privilegiados para o debate, para as trocas e para a emergência de soluções, mas que nem sempre são utilizados adequadamente pelas escolas, preocupadas que estão em atender prioritariamente às burocracias impostas pelo sistema educacional. A formação dos docentes teria que ser, em algum momento, compartilhada não só com os membros da equipe técnica, mas com os funcionários administrativos, operacionais e pais para que todos pudessem estar afinados com a proposta pedagógica assumida pela escola, facilitando a construção daquele ‘sujeito coletivo’ discutido anteriormente.

Paralelamente à formação in locus, não se poderia dispensar outras possibilidades de formação que extrapolassem os muros das escolas e permitissem aos profissionais de educação 'respirarem outros ares', conhecendo novos espaços de produção de conhecimento e de cultura, já que conforme foi reivindicado por uma 
educadora nessa pesquisa, “(...) o professor precisa se alimentar e esse alimento é de conhecimento, é de arte, é de passeio, é de tudo". Assim, as escolas de uma mesma região, por exemplo, poderiam se reunir a cada bimestre, em um local adequado, agradável e acessível a todos, onde houvesse um momento especial para a apreciação de diferentes expressões artísticas produzidas pelas comunidades educativas e por outros artistas, atenuando as tensões do dia-a-dia e ao mesmo tempo, contribuindo para aprimorar a bagagem cultural dos educadores e educandos. As escolas teriam, ainda, a possibilidade de discutir seus problemas e tomar contato com novas estratégias educacionais, por meio de trocas de experiências. E se a apreciação de seus trabalhos fosse seguida por uma teorização de suas práticas, contando com a ajuda de pesquisadores das Universidades, esses momentos especiais de parada para reflexão pedagógica na Rede seriam ainda mais enriquecedores. É importante lembrar que iniciativas desse tipo não chegariam a ser uma inovação, pois já ocorreram de maneira semelhante no passado, mas demandavam consideráveis esforços do ponto de vista da logística e também financeiro e talvez por isso, tenham sido abolidas.

Em uma ação articulada, os órgãos técnicos educacionais precisam possibilitar ainda, o contato das escolas com programas e projetos que viabilizem a prática dos conhecimentos construídos no processo formativo, conferindo verdadeira autonomia às escolas para democratizarem a gestão do espaço, das pessoas e do currículo. Este último precisa estar comprometido com a transformação social e a emancipação dos sujeitos e ser elaborado para ter sintonia com as reais necessidades de cada comunidade escolar e com os fundamentos da nova sociedade que todos almejam construir. Por isso é importante que o foco da formação seja redirecionado, já que quase sempre está voltado para o atendimento dos problemas emergenciais (deficiências de leitura e escrita), porém desconectados de outras questões relevantes, como os problemas socioambientais que abrangem uma complexidade de fatores (ecológicos, sociais, econômicos, políticos, culturais, entre outros). Estes, aliás, demandam uma reflexão filosófica sobre o tipo de ser humano e de se sociedade que se deseja e, portanto, não podem ser desprezados ou relegados a um segundo plano dentro do processo educacional. Os problemas socioambientais, inclusive, encontram-se bastante consolidados dentro do rol de preocupações enfrentadas pela sociedade, com reflexos nas comunidades escolares, haja vista que na maioria das escolas o ambiente não foi considerado saudável e há evidências da interferência dos mesmos na saúde coletiva e 
consequientemente na produtividade dos educadores e na sensação de bem-estar e realização dos educandos.

Boas experiências nesse sentido, também já foram vivenciadas pela Rede em diferentes momentos, mas foram interrompidas e é esse movimento 'vacilante', que condena a educação a uma história de pequenos avanços e importantes retrocessos, já que este é um processo que demanda tempo e investimentos crescentes para construir bases sólidas e frutificar-se.

Assim como os professores, os integrantes das equipes técnicas, muitos concursados, inclusive, apresentam deficiências na sua formação e também carecem de um acompanhamento mais próximo das Coordenadorias, no sentido de verificar o cumprimento de suas funções de formadores e organizadores dos projetos pedagógicos, pois se observou que, além da falta de capacitação técnica, há, por um lado, o 'incômodo' de alguns e por outro, a 'acomodação' de outros sujeitos com as funções burocráticas e uma preocupação gerencial, nos moldes do que foi discutido sobre a visão empresarial do manager, negligenciando o seu verdadeiro papel dentro das escolas e causando prejuízos ao processo educativo desenvolvido nestas.

Cabe aos governos ultrapassarem o plano dos discursos e investir pesadamente recursos financeiros na educação. Mais uma vez, é preciso lembrar que não se oferece aos outros o indisponível para si mesmo: os educadores estão corretos ao afirmarem que os governos e a sociedade não têm se preocupado em melhorar a qualidade de vida dos profissionais de educação e isso implica em melhorar suas condições de trabalho, transformar os seus cenários de atuação em ambientes saudáveis, aptos para a promoção permanente da saúde de toda a comunidade escolar, mas da mesma forma o educador precisa entender primeiro que a escola é um legítimo 'lugar de luta', tanto quanto os demais espaços aos quais ele pertence, pois só assim poderá convencer seus alunos quanto à importância e a urgência destes se tornarem igualmente "cidadãos planetários".

Nada disso, porém surtiria o efeito desejado, sem remexer e desmontar as estruturas arcaicas de poder institucionalizadas nas escolas que imobilizam e distorcem a missão da educação e sem proporcionar uma visão política mais ampla aos educadores (e à comunidade educativa como um todo), para que estes possam ser de fato, agentes 
intelectuais ativistas e transformadores, dentro e fora do espaço escolar e referências para seus educandos e para toda a sociedade.

E se é verdade que não se pode esperar de todo tipo de governo essa iniciativa, tendo em vista que tamanha mudança não motiva, mas afeta os interesses de determinados dirigentes, abre-se então, um espaço importante para os sindicatos da categoria que precisam resgatar o seu papel de formadores e também da maioria das Universidades que não têm tido uma ação eficiente, tanto no sentido de preparar esses profissionais ainda na graduação, como posteriormente, já no exercício do magistério, por meio de cursos oferecidos fora ou dentro da Rede de Ensino.

Finalmente, espera-se daqueles que governam e elaboram as políticas educacionais, bem como dos educadores (e não apenas professores!) a compreensão de que a educação ambiental é um processo permanente de formação a que todos têm direito e deve ser realizada de uma forma dinâmica que permita aos indivíduos revezarem-se nos papéis de educadores e educandos. É nessa troca rica e importante dentro da diversidade de contextos e de idéias e com indivíduos 'res-ponsáveis' (aqueles que buscam respostas de maneira lúcida e refletida) que se construirão os valores, posturas e práticas realmente compatíveis com a educação crítica que defende um mundo mais justo, solidário e equilibrado ambientalmente.

Dentro das escolas a EA pode e deve ser um eixo norteador do PPP, dada à sua capacidade de promover a interação e o entendimento entre as pessoas e destas com o meio em que vivem, seja em suas comunidades locais ou em esferas mais amplas, como a cidade, o país, o planeta. A partir dessa maneira dialógica e interacional de aprendizagem, que considera os diferentes olhares, perspectivas, desejos, direitos e deveres, que se dará o empowerment individual e coletivo, sobretudo das crianças e adolescentes e emergirão oportunidades concretas de participação e ação, movidas pela tomada de consciência e pelo sentimento de co-responsabilidade social cultivado por cada um. Nesse caminho não haverá espaço para a exclusão e o autoritarismo, marcas pedagógicas ainda presentes em muitas escolas. O 'cada um por si' vai dar lugar ao diálogo para melhor entender 'o papel de cada um', na missão que, na verdade, 'é de todos'. E ainda que não seja comum surgirem governantes interessados em investir nessa proposta, se houver em cada comunidade educativa o já mencionado 'desejo 
mobilizador' (que é substancialmente diferente do 'simples desejo'), porque é fruto de uma reflexão critica, a escola vai ter força para rasgar os pequenos espaços de autonomia de que dispõe e, as lutas diárias, travadas no chão de cada escola, serão coletivas e poderão ter uma perspectiva de vitória... Como impedir? 


\section{VII - REFERÊNCIAS}

Albuquerque A. Emancipação, ruptura e inovação: o focus group como instrumento de investigação. In: Educação \& Linguagem. Ano 9.n 13. 196-209, Jan-Jun, 2006.

Almeida EF. Currículo em Paulo Freire: Um estudo dos aspectos técnico, estético, ético e político do currículo, em Paulo Freire. [dissertação de mestrado]. São Paulo: Pontifícia Universidade Católica de São Paulo - PUC-SP; 2002.

Almeida FJ. Retomando a conversa: a construção da política educacional da Secretaria Municipal de Educação - Carta aos educadores. In: São Paulo (Cidade) - Secretaria Municipal de Educação. Revista EducAção nº 1. São Paulo; 2001.

Almeida MC de. Cumplicidade, Complexidade, (Com)paixão. In: Carvalho EA; Almeida MC; Coelho NN; Ferrara NF; Morin E. Ética, Solidariedade e Complexidade. São Paulo: Palas Athenas, 1998 ; (p.25-26).

Alves N. et al. Criar currículo no cotidiano. São Paulo: Cortez, 2002.

Antunes A. (org) \& Gomes AS \&Mesquita DL \& Oliveira LC. Gomes AS. Orçamento Participativo Criança: exercendo a cidadania desde a infância. São Paulo: Instituto Paulo Freire, 2004.

Antelo E. Qué quiere usted de mi? Lo incalculable en el oficio de enseñar. In: Revista La educación em nuestras manos. N.72, octubre de 2004 (versão on line).

Apple MW. The politics of Official Knowledge: does a national curriculum make sense? In: Cultural Politics and Education. Apple MW. Teachers College Record Volume 95, Number 2, Winter 1995. Copyrights by Teachers College, Columbia University. New York, NY; 1995. 
Apple MW. O conhecimento oficial - Editora Vozes. São Paulo; 1997.

Apple MW. Neoliberalismo e Currículo. In: Revista Pátio. Ano X, Fev/Abr: 2006 p.13-15. Ministério da Educação - FNDE - Artmed Editora.

Barbosa JG. Multirreferencialidade nas ciências e na educação. São Carlos, Editora da UFSCar; 1998.

Basch CE. Focus group interview: an underutilized research technique for improving theory and practice in health education. In: Health Educ Q, v.14, n.4, p 411-41, 1987.

Bauman Z. Pós modernidade e crise moral e cultural. In: Em busca da política. Rio de Janeiro, Jorge Zahar Editor, 2000, 144-156.

Barbosa JG. Educação para a formação de autores-cidadãos. In: Multirreferencialidade nas ciências e na educação. Editora da UFSCar. São Paulo; 1998.

Beck U. A reinvenção da política. In: Giddens A.et al. Modernidade Reflexiva. São Paulo: UNESP; 1997.

Bernardo AV \& Eulálio MLB \& Sousa RF. Cuidar do Piauí para mudar o Brasil: uma visão estatística do Programa "Vamos cuidar do Brasil com as Escolas". In: Brasil Órgão Gestor da Política Nacional de Educação Ambiental - Ministério do Meio Ambiente e Ministério da Educação. Juventude, Cidadania e Meio Ambiente Subsídios para a elaboração de políticas públicas. Brasília -DF, 2006.

Boff L. Que significa crise? Metade de SP não tem interesse em política. In: Jornal Folha de São Paulo. 07 de Julho de 1983. Opinião (Tendências/Debates) - p.3.

Brandão CR (Org.). O educador: vida e morte. Rio de Janeiro: Graal, 1983. 
Brasil - Ministério da Saúde. Fundação Oswaldo Cruz, IEC. Promoção da Saúde: Carta de Otawa, Declaração de Adelaide, Declaração de Sunsdwall e Declaração de Bogotá. Brasília, 1996.

Brasil - Ministério da Saúde. Sistema Nacional de Vigilância Ambiental em Saúde. Brasília: Fundação Nacional de Saúde, 2001.

Brasil - Órgão Gestor da Política Nacional de Educação Ambiental - Ministério do Meio Ambiente e Ministério da Educação. Juventude, Cidadania e Meio Ambiente Subsídios para a elaboração de políticas públicas. Brasília -DF, 2006.

Brasil - Ministério da Educação (MEC). II Conferência Nacional do Meio Ambiente/II Conferência Infanto-Juvenil do Meio Ambiente. Disponível em: http://www.conferenciainfantojuvenil.com.br/index.php (acesso em 17 de Agosto de 2007).

Briggs B. Introducción al processo de consenso. México, 2000.

Buss PM. (Ed). Promoción de la salud y la salud pública: una contribuición para el debate entre las escuelas de salud pública de America Latina y el Caribe. Rio de Janeiro: FIOCRUZ; Brasília: UnB, 1998.

Bydlowski CR; Westphal MF; Pereira IMTB. Promoção da Saúde. Porque sim e porque ainda não. In: Revista Saúde e Sociedade. Faculdade de Saúde Pública - USP, v.13, nº 1 (jan/abr) - São Paulo; 2004 (p.14 a 24)

Calder B. Focus Group and the Nature of Qualitative Marketing research. J. Marketing Res. 1997; (14) $353-64$.

Caplan S. Using Focus Group Methodology for Ergonomic Desing. Ergonomics 1990; $33(5) ; 527-33$. 
Carnoy M. \& Levin HM. Schooling and work in the democratic state. Stanford, Stanford University Press, 1985.

Cascino F. Educação Ambiental: eixos teóricos para uma reflexão curricular. In: São Paulo (Estado) - Secretaria Estadual do Meio Ambiente/CEAM - Educação, Meio Ambiente e Cidadania. Reflexos e Experiências. Cascino F, Jacobi P, Oliveira F (org.). SP: SMA (CEAM), 1998.

Castellanos PL. Los modelos explicativos del processo salud-enfermidad: los determinantes sociales. In: Martinez Navarro, F. et al. Salud Pública. Madrid: McgrawHill - Interamericana, 1998. (p.81 a 102).

Castro M. Prática de Pesquisa. São Paulo; McGraw Hill do Brasil, 1997.

Catford J. Ottawa 1986: Piedra angular del desarrollo de la salud mundial. In: Promotion \& Education. The Ottawa Charter for Health Promotion: a critical reflection - Background to the 19 ${ }^{\mathrm{TM}}$ IUHPW World Conference on Health Promotion and Health Education, "Health Promotion Comes of Age: Research, Policy \& Practice for the $21^{\text {st }}$. Century”. Supplement - Hors-série- Edición especial 2. International Union for Health Promotion and Education. France. 2007. p.53-54

Centre for Health Education and Health Promotion (CHEHP) - Faculty of Medicine The Chinese University of Hong Kong. The Hong Kong Health Schools Award Scheme.Special Issue, Hong Kong; 2006.

Certeau M. de. A Invenção do Cotidiano: as artes de fazer. Petrópolis: Vozes, 1996.

Cesar MR de A. Por uma genealogia da adolescência. In: Cadernos da FCC. V. 9, n.1. 2000. Faculdade de Filosofia e Ciências. UNESP. Marília. 
Cortella MS. A Escola e o conhecimento - fundamentos epistemológicos e políticas. $5^{\text {a }}$ ed. São Paulo: Cortez: Instituto Paulo Freire, 2001 (Coleção Prospectiva; 5).

Diegues ACS. Desenvolvimento sustentável ou sociedades sustentáveis - da crítica dos modelos aos novos paradigmas. São Paulo em perspectiva. 6 (1/1): 22-9, 1992.

Doll Jr WE. Currículo: uma perspectiva pós-moderna. Porto Alegre: Artes Médicas, 1997. Freire P. Conscientização: teoria e prática da libertação: uma introdução ao pensamento de Paulo Freire. São Paulo: Editora Moraes Ltda, 3.ed. 1980

Ferraço CE. Possibilidades para entender o currículo escolar. In: Revista Pátio. Ano X, Fev/Abr: 2006 - p.32-35. Ministério da Educação - FNDE - Artmed Editora.

Franco Netto G. \& Carneiro FF. A vigilância Ambiental em Saúde e a promoção de ambientes saudáveis. Revista da Saúde, Brasília: Conselho Nacional de Saúde (CNS) ano IV $-\mathrm{n}^{\circ} 4-\mathrm{p}, 32-3$, abril/2003.

Freire P. Conscientização: teoria e prática da libertação: uma instrodução ao pensamento de Paulo Freire. (tradução de Kátia de Mello e Silva, revisão técnica de Benedito Eliseu Leite Cintral) - 3.ed. São Paulo: Moraes, 1980.

Freire P \& Shor I. Medo e ousadia - O cotidiano do professor. Rio de Janeiro: Paz e Terra, 1986.

Freire P. Pedagogia da Autonomia: saberes necessários à prática educativa. São Paulo: Paz e Terra, 1996 (Coleção Leitura).

Freire P. Política e Educação: Ensaios. 6.ed. São Paulo: Cortez, 2001 (Coleções Questões da Nossa Época; v.23).

Freire P. Pedagogia da Esperança: um reencontro com a pedagogia do oprimido. $13^{\mathrm{a}}$. Ed. Rio de Janeiro: Paz e Terra, 2005. 
Gadotti M. Pedagogia da Terra. São Paulo: Peirópolis; 2000.

Gadotti M \& Freire P. \& Guimarães S. Pedagogia: diálogo e conflito. $6^{\text {a }}$ Ed. São Paulo: Cortez, 2001.

Gadotti M \& Romão JE (org). Autonomia da Escola: Princípios e Propostas. Guia da Escola Cidadã. São Paulo. Cortez, Instituto Paulo Freire, 4ª ed. 2001.

Gasparini SM; Barreto SM; Assunção AA. O professor, as condições de trabalho e os efeitos sobre sua saúde. Revista Educação e Pesquisa. São Paulo. V.31, n 2,p.189-199, maio/ago.2005.

Gil AC. Métodos e Técnicas de Pesquisa social. São Paulo: Atlas; 1994.

Glik, D \& Gordon A. A focus group method for formative research in child survival. An Ivorian example. Int Q Comm Health Educ, v.1, n.4, p. 297-315, 1988.

Gohn MG. Movimentos Sociais e Educação. 5a Ed. São Paulo: Cortez, 2001 (Coleção Questões da nossa época, v.5).

Goodson I. Currículo: teoria e história. Petrópolis: Vozes, 1995.

Guivant J. A trajetória das análises de risco: da periferia ao centro da teoria social. Revista Brasileira de Informação Bibliográfica em Ciências Sociais [periódico on-line] 1998; (46). Disponível em: URL http://www.anpocs.org.br/bib/bib46.htm\#Trajetoria

Haddad F. A formação docente é prioridade para o Ministério. Revista Nova Escola. Editora Abril. Ano XXIII, no 216 - Outubro de 2008. (p.32-36).

Hills M \& McQueen DV. At issue: two decades of the Ottawa Charter. In: Promotion \& Education. The Ottawa Charter for Health Promotion: a critical reflection - 
Background to the 19 ${ }^{\mathrm{TM}}$ IUHPE World Conference on Health Promotion and Health Education, "Health Promotion Comes of Age: Research, Policy \& Practice for the $21^{\text {st }}$. Century". Supplement - Hors-série- Edición especial 2. International Union for Health Promotion and Education. France; 2007. (p.5).

Huberman M. Survol d'une étude de la carrière des enseignants. Vais-je mourir debout au tableau noir une craie à la main ? Journal de l'enseignement secondaire, $n^{\circ}$ 6, p.5-8. Abril, 1989.

Huberman M. La vie des enseignants. Évolution et bilan d'une profession, Neuchâtel et Paris, Delachaux et Niestlé ; 1989a.

Iervolino SA \& Pelicioni MCF A utilização do rupo focal como metodologia qualitativa na promoção da saúde. Rev. Esc. Enf. USP, v. 35, n.2, p.115-21, jun., 2001.

Jacobi P. Educação Ambiental e Cidadania. In: São Paulo (Estado) - Secretaria Estadual do Meio Ambiente/CEAM - Educação, Meio Ambiente e Cidadania. Reflexos e Experiências . São Paulo; 1998

Jacobi P. Educação Ambiental: o desafio da construção de um pensamento crítico, complexo e reflexivo. Disponível em: www.scielo.br/pdf/ep/v32n2/a07v32n2.pdf. maio/agosto 2005. Acesso em 14 de setembro de 2005.

Krueger RA. Focus Group: A pratical guide for applied research. Thousand Oaks; SAGE; 1994.

Lakatos EM \& Marconi M de A. Fundamentos de Metodologia Cientifica. São Paulo: Editora Atlas S.A., $3^{\text {a }}$ edição; 1991.

Leff H. Saber Ambiental: sustentabilidade, racionalidade, complexidade, poder. Trad. Orth LME. Petrópolis, RJ: Vozes, 2001 
Leis HR. Um moderno mercado verde. Jornal do Brasil, 2 fev., Idéias e Ensaios: 1992.

Leis HR. A Modernidade insustentável: as críticas do ambientalismo à sociedade contemporânea. Petrópolis, RJ: Vozes: Santa Catarina: UFSC, 1999.

Linhares C (org). Os professores e a reinvenção da escola - Brasil e Espanha. Santomé JT, Frigotto G, Silva WC, Gil JMS, Linhares C. São Paulo: Cortez, 2001; $2^{\mathrm{a}}$ ed.

Mannheim k. Ideologia e utopia. Rio de Janeiro: Guanabara, 1986).

Meira PC. Educación Ambiental en tiempos de catástrofe: la respuesta educativa al naufrágio del Prestige. In: Educação e Pesquisa - Revista da Faculdade de Educação da USP. São Paulo; V.31, nº 2, p.265-283, maio/ago. 2005.

Meirieu Ph. Apprendre...oui mais comment? Paris, ESF éditeur ; 1989. 4.ed.

Mello FB de. \& Bedinelli T. Metade de SP não tem interesse em política. Jornal Folha de São Paulo. 04 de Outubro de 2008. Caderno Mais - Especial 3.

Minayo MC. O Desafio do Conhecimento - Pesquisa Qualitativa em Saúde. Rio de Janeiro: Hucitec-Abrasco; 1994.

Minayo MS; Hartz SMS; Buss PM. Qualidade de vida e saúde: um debate necessário. Ciência e Saúde Coletiva, Rio de Janeiro, RJ, V.5, n.1, p.7-18, mar.2000.

Morgan D. Focus group as qualitative research. Qualitative Research Methods Series. 16, London: Sage Publications, 1997.

Morin E \& Kern AB. Terra Pátria. Portugal: Instituto Piaget; 1993. A Agonia Planetária; p.53-81. 
Morin E. A ética do sujeito responsável. In: Carvalho EA; Almeida MC; Coelho NN; Ferrara NF; Morin E. Ética, Solidariedade e Complexidade. São Paulo: Palas Athenas, 1998 (p.68).

Morin E. Os sete saberes necessários a educação do futuro. São Paulo, Cortez: Brasília, DF: UNESCO, 2002. $6^{\mathrm{a}}$ ed.

Moscovici S. A representação social da psicanálise. Rio de Janeiro: Zahar; 1978.

Muñoz C. Pedagogia da vida cotidiana e participação cidadã. São Paulo: Cortez, 2004.

Oliveira IB de. Práticas Curriculares Emancipatórias no Cotidiano da Escola. In: Revista Pátio. Ano X, Fev./Abr: 2006 - p.32-35. Ministério da Educação - FNDE Artmed Editora.

Organização Mundial da Saúde (OMS). Primera Conferencia de la Red Europea de Escuelas promotoras de Salud. "La Escuela promotora de Salud - una inversión en educación, salud y democracia”. Salónica-Halkidiki, Grecia, 1-5 mayo 1997 (Resolución de la Conferencia - mimeo).

Organização Mundial da Saúde (OMS) - Escritório Regional para a África. A Saúde na África em 2000-2001. Documento de Balanço - 8-12 out. 2002. (Disponível em: http://www.afro.who.int/press/portuguese/2002/pr20021008-1201.html. Acesso em 31 de Agosto de 2007).

Organización Panamericana de la Salud (OPAS). Escuelas Promotoras de la Salud iniciativa de las Américas de Salud y Educación para el Desarrollo Humano Sostenible.Unidad de Entornos Saludables, Área de Salud Ambiental y Desarrollo Sostenible. Washington, DC, USA; 2003 a.

Organización Panamericana de la Salud (OPAS). Escuelas Promotoras de la SaludFortalecimiento de la Iniciativa Regional. Estrategias y Líneas de Acción 2003-2012. Washington, DC, USA; 2003 b. 
Parasuraman A. Marketing Research. Toronto; Addison- Waley, 1986.

Paro VH. Gestão Democrática da Escola Pública. São Paulo: Editora Ática, 2002.

Pelicioni MCF. Escuelas promotoras de la salud - entornos saludables y mejor salud para las generaciones futuras. In: Comunicación para la salud $\mathrm{n}^{\mathbf{0}} 13$. Organizacion Panamericana de la Salud. Oficina Sanitária Panamericana, Oficina Regional de la Organización Mundial de la Salud; 1998. Washington. DC., USA.

Pelicioni MCF. Educação Ambiental, qualidade de vida e sustentabilidade. Revista Saúde e Sociedade , 1998a ,7(2): 19-31.

Pelicioni MCF \& Phillipi Junior A. Meio Ambiente, Direito e Cidadania: Uma Interação Necessária. In: Meio Ambiente, Direito e Cidadania. Phillipi Jr.A, Alves AC, Roméro MA, Bruna GC, Editores. São Paulo: Universidade de São Paulo. Faculdade de Saúde Pública, Faculdade de Direito, Faculdade de Arquitetura e Urbanismo, Núcleo de Informações em Saúde Ambiental: Signus Editora, 2002. p.347-351.

Pelicioni MCF. Educação ambiental para uma escola saudável. In: Phillipi Jr.A \& Pelicioni MCF, Editores. Educação Ambiental e sustentabilidade. Barueri, SP: Manole: 2004. P.827-48.

Perrenoud P. Novas competências para ensinar. Trad. Patrícia Chittoni Ramos. - Porto Alegre: Artes Médicas Sul, 2000.

Phillipi Jr \& Pelicioni MCF (editores). Educação Ambiental: desenvolvimento de cursos e projetos. USP/FSP - NISAM: Signus Editora, 2000.

Pontual P. Orçamento Participativo em Santo André. In: Partido dos Trabalhadores; Secretaria Nacional de Assuntos Institucionais; Fundação Perceu Abramo. Orçamento Participativo - Experiências em administrações municipais e estaduais. [CD ROM].Brasília: 2000. 
Printes RC. Atire a primeira pedra quem nunca pescou. In: Educação ambiental: vários olhares e várias práticas. Kindel EAI; Silva FW; Sammarco YM (org). Porto Alegre: Mediação, 2004. p.23.

Ramirez AG \& Shepperd J. The use of focus grouping health research. Scand. J Primary Healthy Care, supl. 1, p. 11-90, 1988.

Reigota M. Desafios à Educação Ambiental Escolar. In: São Paulo (Estado) - Secretaria Estadual do Meio Ambiente/CEAM - Educação, Meio Ambiente e Cidadania. Reflexos e Experiências . São Paulo; 1998

Reigota M (org.) Verde Cotidiano - O meio ambiente em discussão. DP\&A Editora: São Paulo; 1999.

Reigota M. Meio ambiente e representação social.São Paulo, Cortez: 2001, $4^{\mathrm{a}}$ ed.

Ribeiro H. Saúde Pública e Meio Ambiente: evolução do conhecimento e da prática, alguns aspectos éticos. Revista Saúde e Sociedade. Faculdade de Saúde Pública - USP, v.13, no 1 (jan/abr ) - São Paulo; 2004 (p.70-80).

Rios TA. Ética e Competência. 11 ${ }^{\mathrm{a}}$ Ed. São Paulo: Cortez, 2001 (Coleção Questões da nossa época; v.16).

Rodrigues N. Lições do Príncipe e Outras Lições. 20 ed. São Paulo, Cortez, 2001 (Coleção Questões da Nossa Época; v.15)

Romão JE; Gadotti M; Torres CA; Garcia WE; Gutierrez F; Lownds P. Manifesto da Planetarização. In: Educação \& Linguagem. Ano.9, no 13, 79-97, jan-jun. 2006. (p.210211). 
Sacristán GJ. Currículo e diversidade cultural. In: Silva TT; Moreira AF (Orgs). Territórios Contestados - O currículo e os novos mapas políticos e culturais. Petrópolis: Vozes, 1995.

Sánchez F. O orçamento participativo em São Paulo (2001/2004): uma inovação democrática. In: Avritzer L.(org). A participação em São Paulo. São Paulo: Editora UNESP; 2004.

Sancho J. Currículo é tudo o que acontece na escola. In: Ferraço CE. Possibilidades para entender o currículo escolar. In: Revista Pátio. Ano X, Fev/Abr: 2006 - p.20-23. Ministério da Educação - FNDE - Artmed Editora.

Santomé JT. O professorado em época de neoliberalismo: dimensões sociopolíticas de seu trabalho. In: Linhares C (org). Os professores e a reinvenção da Escola - Brasil e Espanha. Santomé JT, Frigotto G, Silva WC, Gil JMS, Linhares C. São Paulo: Cortez, 2001; $2^{\mathrm{a}}$ ed. - p. 17-56.

Santos BS. Pela mão de Alice: o social e o político na pós-modernidade. São Paulo: Cortez, 2005; $10^{\mathrm{a}}$ ed.

Santos Neto E. Esperança, Utopia e Resistência na formação e prática de educadores no contexto neoliberal. In: Revista de Educação do COGEIME. Piracicaba: v. 13, n.24, p. 53-69; 2004.

Santos Neto E. Filosofia e prática docente: fundamentos para a construção da concepção pedagógica do professor e do projeto político-pedagógico na escola. In: Anais do II Encontro Internacional de Filosofia e Educação - Fórum Sudeste do Ensino de Filosofia: "Política do ensino de Filosofia" [CD-ROM]; 9 a 11 de setembro de 2004. Rio de Janeiro, BR. Rio de Janeiro: UERJ; 2004a.

Santos Neto E. Projeto Político-Pedagógico: Desafios práticos de sua construção como documento e como ação pedagógica. In: Universidade Metodista de São Paulo. Pedagogia: Projeto Político-Pedagógico, Prática Docente, Pesquisa. São Bernardo do Campo: Universidade Metodista de São Paulo, Julho de 2008, p. $94-97$ (Cadernos 
Didáticos Metodista - Campus EAD).ISBN: 978-85-7814-041-0.São Bernardo do Campo: UMSP; 2008.

Santos Neto E. Projeto Político-Pedagógico: Algumas possíveis articulações com a prática pedagógica no cotidiano da escola. In: Universidade Metodista de São Paulo. Pedagogia: Projeto Político-Pedagógico, Prática Docente, Pesquisa. São Bernardo do Campo: Universidade Metodista de São Paulo, Julho de 2008, p. 100-103 (Cadernos Didáticos Metodista - Campus EAD).ISBN: 978-85-7814-041-0.São Bernardo do Campo: UMSP; 2008a

São Paulo (Cidade) - Secretaria Municipal de Educação. Revista EducAção no ${ }^{\circ}$. São Paulo; 2001.

São Paulo (Cidade) - Secretaria Municipal de Educação. Revista EducAção nº 2. São Paulo; 2001a.

São Paulo (Cidade) - Secretaria Municipal de Educação. Revista EducAção nº 4. São Paulo; 2003.

São Paulo (Cidade) - Secretaria Municipal de Educação. Revista EducAção nº 5. São Paulo; 2004.

São Paulo (Cidade) - Estudo alerta sobre saúde dos alunos na rede pública. Disponível em http://www.prefeitura.sp.gov.br/portal/a_cidade/noticias/index.php?p=1971 de 17 de Maio de 2005 - 9:17 horas (acesso em 04 de setembro de 2007).

São Paulo (Cidade). Secretarias dão início à $2^{\mathrm{a}}$ Semana Promotora de Saúde nas Escolas. 29 de Maio de 2006. Disponível em: http:// www.prefeitura.sp.gov.br/portal/a_cidade/noticias/index.php?p=9933 (acesso em 04 de setembro de 2007).

São Paulo (Cidade) - Secretaria Municipal de Educação. Escola Promotora de Saúde. São Paulo, 2007a. Disponível em http://educacao.prefeitura.sp.gov.br/WebModuleSme/itemMenuPaginaConteudoUsuari 
$\underline{\text { oAction }}$. do $?$ service $=$ PaginaItemMenuConteudoDelegate $\&$ actionType $=$ mostrar $\&$ idPagin

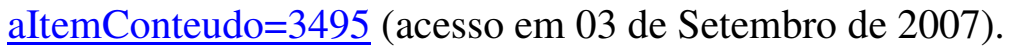

São Paulo (Cidade) - Secretaria Municipal de Educação. Projeto Escola Promotora de Saúde. São Paulo, 2007b. Disponível em http://portal.prefeitura.sp.gov.br/secretarias/saude/crianca/0014 (acesso em 04 de Setembro de 2007).

Saviani D. Ensino sem demagogia. In: Jornal Folha de São Paulo. 13 de Julho de 2008; Caderno Mais, p.3.

Savola ES. The development of Health and Social Welfare Policy in Soukka School. In: 19тM IUHPE World Conference on Health Promotion and Health Education, "Health Promotion Comes of Age: Research, Policy \& Practice for the $21^{\text {st }}$. Century"; Jun 1115; Vancouver, Canadá. Vancouver: 2007.

Scocuglia AC. Educação globalizada e pedagogia freiriana: desafios e combates contemporâneos. In: Educação \& Linguagem. Ano.9, nº 13, 79-97, jan-jun. 2006.(p.78).

Sebastiani RW. O adolescente em situação de risco social: uma intervenção para promoção de saúde. [dissertação de mestrado apresentada à Faculdade de Saúde Pública - USP] São Paulo, 2004.

Shor I. In: Freire P \& Shor I. Medo e Ousadia - O cotidiano do professor. Rio de Janeiro: Paz e Terra, 1986.

Silva JM. A autonomia da escola pública: a re-humanização da escola. Campinas: Papirus, 1996.

Silva TT. Identidades Terminais: as transformações na política da pedagogia e na pedagogia da política. Ed. Vozes: Petrópolis - RJ, 1996. 
Silva TT \& Moreira AF. Territórios Contestados: o currículo e os novos mapas políticos e culturais. 5aEd. Editora Vozes: Petrópolis - RJ, 1995.

Silveira GT. Escola Promotora de Saúde: Quem sabe faz a hora! [Tese de doutorado]. Faculdade de Saúde Pública. Universidade de São Paulo. São Paulo; 2000.

Spinelli E. \& Bedinelli T. Apatia. Região não se interessa por política nem por cultura. In: Jornal Folha de São Paulo. 21 de Setembro de 2008. Caderno Mais - Especial 5.

Sultana RG. Social movements and the transformation of teacher work: Case studies from New Zealand. In: Research papers in education, v.6. n.2, 1991.

Takahashi F \& Sangiovanni R. 29\% dos alunos de $2^{\mathrm{a}}$ série da prefeitura não sabem o que lêem. In: Jornal Folha de São Paulo. 2 de Fevereiro de 2008; Cotidiano p.C3.

Toro JB \& Werneck NMD. Mobilização Social - um modo de construir a democracia e a participação. Belo Horizonte: Autêntica: 2004.

Tozoni-Reis MFC. Educação Ambiental: Natureza, Razão e História. Campinas, SP: Autores Associados, 2004 (Coleção educação contemporânea).

UNESCO. Educação para um futuro sustentável: uma visão transdisciplinar para ações corpartilhadas. Brasília: Ed. IBAMA, 1999.

Viola EJ \& Leis HR. A evolução das políticas ambientais no Brasil, 1971-1991: do bissetorialismo preservacionista para o multissetorialismo orientado para $\mathrm{o}$ desenvolvimento sustentável. In: Hogan, DJ (org.) Dilemas sócio-ambientais e desenvolvimento sustentável. Campinas: Ed. UNICAMP; 1992. 
Westphal MF. A utopia, a educação e os projetos em educação ambiental. In: Educação Ambiental: desenvolvimento de cursos e projetos. Philippi Jr.A \& Pelicioni MCF. (org). USP/FSP - NISAM: Signus Editora, 2000; (p.171-177).

Wills W., Appleton J., Brooks F., Magnusson J. Children, Young People and Schools: Building Effective Health Promotion and Public Health Policy by Listening and Acting on the Views of the Yong. In: 19 ${ }^{\mathrm{TM}}$ IUHPE World Conference on Health Promotion and Health Education, "Health Promotion Comes of Age: Research, Policy \& Practice for the $21^{\text {st }}$. Century"; Jun 11-15; Vancouver, Canadá. Vancouver: 2007.

Zagury T. O professor refém - para pais e professores entenderem por que fracassa a educação no Brasil. Rio de Janeiro: Record, 2006. 
ANEXO 1 - Termo de Consentimento livre e esclarecido - pesquisa com professores

Pesquisa: "OLHARES E PERSPECTIVAS SOBRE A EDUCAÇÃO AMBIENTAL, A DEMOCRACIA PARTICIPATIVA E O EMPOWERMENT DE CRIANÇAS E ADOLESCENTES EM ESCOLAS DA REDE MUNICIPAL DE ENSINO DE SÃO PAULO”

Pesquisadora: Mirtes Moreira Silva

OBJETIVOS: Este trabalho pretende investigar a existência de projetos de educação ambiental que tenham como principais atores as crianças e os adolescentes de escolas da Rede Municipal de Ensino de São Paulo. Busca, ainda, identificar as representações dos educadores, pais e alunos a respeito de tais projetos, a respectiva contribuição para a realização dos mesmos, bem como as dificuldades que interferem na concretização dos projetos. Com este estudo, espera-se poder contribuir para a construção de escolas mais saudáveis e para o aprimoramento de práticas pedagógicas que favoreçam a sustentabilidade ambiental e o exercício da cidadania plena desde a infância.

PROCEDIMENTOS: A coleta de dados será feita por meio de questionários que serão entregues às equipes técnicas das escolas, entrevistas direcionadas a alunos e pais, gravadas em fita-cassete, após concordância individual e grupo focal (técnica de entrevista coletiva onde o pesquisador atua como mediador). Cabe salientar que esta pesquisa não implicará em qualquer tipo de risco aos participantes, que terão suas identidades protegidas, havendo devolução dos resultados coletivos, após concluída a investigação aos interessados, sem qualquer identificação. Maiores informações e retorno dos resultados poderão ser obtidos com a responsável pela pesquisa.

Pesquisadora responsável - Prof ${ }^{\mathrm{a}}$ Mirtes Moreira Silva

Av. Águia de Haia, 2100, bloco 2 - apto 12 -Pq. Paineiras

SP - Capital, CEP 03694-000.

(11) 9195-2108 - silvapedroso@ uol.com.br

Orientadora: Prof ${ }^{\mathrm{a}}$ Dr$^{\mathrm{a}}$ Maria Cecília Focesi Pelicioni

Tel. 3066-7751 - Faculdade de Saúde Pública/USP

Depto. de Prática de Saúde Pública

Comitê de Ética da Faculdade de Saúde Pública - 3066-7779 


\section{TERMO DE CONSENTIMENTO LIVRE E ESCLARECIDO}

$\mathrm{Eu}$,

representante da comunidade educativa da Escola na função de professor, aceito participar da pesquisa intitulada "Olhares e perspectivas sobre a educação ambiental, a democracia participativa e o empowerment de crianças e adolescentes em escolas da Rede Municipal de Enisno de São Paulo". Estou ciente de que minha participação é livre, não obrigatória e de que poderá ser interrompida por minha decisão a qualquer momento, sem qualquer prejuízo. Sei que minha entrevista não será identificada, concordo que ela seja gravada e que a fita fique em poder da pesquisadora durante o período necessário para a conclusão da pesquisa. Se houver necessidade de novas informações procurarei a pesquisadora no endereço acima.

Participante da pesquisa

São Paulo,

de de 200 
ANEXO 1 - Termo de Consentimento livre e esclarecido - pesquisa com integrantes das equipes técnicas

\author{
Pesquisa: "OLHARES E PERSPECTIVAS SOBRE A EDUCAÇÃO AMBIENTAL, A \\ DEMOCRACIA PARTICIPATIVA E O EMPOWERMENT DE CRIANÇAS E \\ ADOLESCENTES EM ESCOLAS DA REDE MUNICIPAL DE ENSINO DE SÃO PAULO”
}

Pesquisadora: Mirtes Moreira Silva

OBJETIVOS: Este trabalho pretende investigar a existência de projetos de educação ambiental que tenham como principais atores as crianças e os adolescentes de escolas da Rede Municipal de Ensino de São Paulo. Busca, ainda, identificar as representações dos educadores, pais e alunos a respeito de tais projetos, a respectiva contribuição para a realização dos mesmos, bem como as dificuldades que interferem na concretização dos projetos. Com este estudo, espera-se poder contribuir para a construção de escolas mais saudáveis e para o aprimoramento de práticas pedagógicas que favoreçam a sustentabilidade ambiental e o exercício da cidadania plena desde a infância.

PROCEDIMENTOS: A coleta de dados será feita por meio de questionários que serão entregues às equipes técnicas das escolas, entrevistas direcionadas a alunos e pais, gravadas em fita-cassete, após concordância individual e grupo focal (técnica de entrevista coletiva onde o pesquisador atua como mediador). Cabe salientar que esta pesquisa não implicará em qualquer tipo de risco aos participantes, que terão suas identidades protegidas, havendo devolução dos resultados coletivos, após concluída a investigação aos interessados, sem qualquer identificação. Maiores informações e retorno dos resultados poderão ser obtidos com a responsável pela pesquisa.

Pesquisadora responsável - Prof ${ }^{\mathbf{a}}$ Mirtes Moreira Silva

Av. Águia de Haia, 2100, bloco 2 - apto 12 -Pq. Paineiras

SP - Capital, CEP 03694-000.

(11) 9195-2108 - silvapedroso@uol.com.br

Orientadora: Prof ${ }^{\mathrm{a}}$ Dr$^{\mathrm{a}}$ Maria Cecília Focesi Pelicioni

Tel. 3066-7751 - Faculdade de Saúde Pública/USP

Depto. de Prática de Saúde Pública

Comitê de Ética da Faculdade de Saúde Pública - 3066-7779 


\section{TERMO DE CONSENTIMENTO LIVRE E ESCLARECIDO}

$\mathrm{Eu}$,

representante da comunidade educativa da Escola na função de aceito participar da pesquisa intitulada "Olhares e perspectivas sobre a educação ambiental, a democracia participativa e o empowerment de crianças e adolescentes em escolas da Rede Municipal de Enisno de São Paulo". Estou ciente de que minha participação é livre, não obrigatória e de que poderá ser interrompida por minha decisão a qualquer momento, sem qualquer prejuízo. Sei que minha entrevista não será identificada, concordo que ela seja gravada e que a fita fique em poder da pesquisadora durante o período necessário para a conclusão da pesquisa. Se houver necessidade de novas informações procurarei a pesquisadora no endereço acima.

Participante da pesquisa

São Paulo, de de 200 
ANEXO 1 - Termo e Consentimento Livre e Esclarecido - pesquisa com alunos

Pesquisa: "OLHARES E PERSPECTIVAS SOBRE A EDUCAÇÃO AMBIENTAL, A DEMOCRACIA PARTICIPATIVA E O EMPOWERMENT DE CRIANÇAS E ADOLESCENTES EM ESCOLAS DA REDE MUNICIPAL DE ENSINO DE SÃO PAULO"

Pesquisadora: Mirtes Moreira Silva

OBJETIVOS: Este trabalho pretende descobrir se existem projetos de educação ambiental nas escolas da Rede Municipal de Ensino de São Paulo e como as crianças e adolescentes que estudam nessas escolas têm participado desses projetos. Deseja também verificar o que os alunos, pais e educadores acham desses projetos e como eles ajudam para que eles aconteçam nas escolas. Assim, esse estudo quer auxiliar para que o ambiente escolar seja mais saudável e para que os alunos aprendam desde a infância como se tornarem verdadeiros cidadãos, lutando pelos seus direitos e cumprindo seus deveres para construírem um mundo melhor para todos.

PROCEDIMENTOS: Essas informações serão colhidas por meio de questionários que serão respondidos pelos diretores, assistentes de direção e coordenadores pedagógicos das escolas, entrevistas com alunos e pais e grupo focal, uma entrevista coletiva, com professores, que serão gravados em fita cassete, se todos concordarem. Esta pesquisa não trará qualquer tipo de problema ou risco aos participantes, que não terão seus nomes revelados e que serão informados de todos os resultados coletivos, ao término da mesma.

Pesquisadora responsável - Prof ${ }^{a}$ Mirtes Moreira Silva

Av. Águia de Haia, 2100, bloco 2 - apto 12 -Pq. Paineiras

SP - Capital, CEP 03694-000.

(11) 9195-2108 - silvapedroso@uol.com.br

Orientadora: Prof ${ }^{\mathrm{a}}$ Dr $^{\mathrm{a}}$ Maria Cecília Focesi Pelicioni

Tel. 3066-7751 - Faculdade de Saúde Pública/USP

Depto. de Prática de Saúde Pública

Comitê de Ética da Faculdade de Saúde Pública - 3066-7779 


\section{TERMO DE CONSENTIMENTO LIVRE E ESCLARECIDO}

$\mathrm{Eu}$, aluno desta Escola, aceito participar da pesquisa intitulada "Olhares e perspectivas sobre a educação ambiental, a democracia participativa e o empowerment de crianças e adolescentes em escolas da Rede Municipal de Enisno de São Paulo". Estou ciente de que minha participação é livre, não obrigatória e de que poderá ser interrompida por minha decisão a qualquer momento, sem qualquer prejuízo. Sei que minha entrevista não será identificada, concordo que ela seja gravada e que a fita fique em poder da pesquisadora durante o período necessário para a conclusão da pesquisa. Se houver necessidade de novas informações procurarei a pesquisadora no endereço acima.

Participante da pesquisa

São Paulo, de de 200

Pai/mãe ou responsável 
ANEXO 1 - Termo e Consentimento Livre e Esclarecido - pesquisa com pais

Pesquisa: "OLHARES E PERSPECTIVAS SOBRE A EDUCAÇÃO AMBIENTAL, A DEMOCRACIA PARTICIPATIVA E O EMPOWERMENT DE CRIANÇAS E ADOLESCENTES EM ESCOLAS DA REDE MUNICIPAL DE ENSINO DE SÃO PAULO”

Pesquisadora: Mirtes Moreira Silva

OBJETIVOS: Este trabalho pretende descobrir se existem projetos de educação ambiental nas escolas da Rede Municipal de Ensino de São Paulo e como as crianças e adolescentes que estudam nessas escolas têm participado desses projetos. Deseja também verificar o que os alunos, pais e educadores acham desses projetos e como eles ajudam para que eles aconteçam nas escolas. Assim, esse estudo quer auxiliar para que o ambiente escolar seja mais saudável e para que os alunos aprendam desde a infância como se tornarem verdadeiros cidadãos, lutando pelos seus direitos e cumprindo seus deveres para construírem um mundo melhor para todos.

PROCEDIMENTOS: Essas informações serão colhidas por meio de questionários que serão respondidos pelos diretores, assistentes de direção e coordenadores pedagógicos das escolas, entrevistas com alunos e pais e grupo focal, uma entrevista coletiva, com professores, que serão gravados em fita cassete, se todos concordarem. Esta pesquisa não trará qualquer tipo de problema ou risco aos participantes, que não terão seus nomes revelados e que serão informados de todos os resultados coletivos, ao término da mesma.

Pesquisadora responsável - Prof ${ }^{\text {a }}$ Mirtes Moreira Silva

Av. Águia de Haia, 2100, bloco 2 - apto 12 -Pq. Paineiras

SP - Capital, CEP 03694-000.

(11)9195-2108 - silvapedroso@uol.com.br

Orientadora: Prof ${ }^{\mathrm{a}}$ Dr $^{\mathrm{a}}$ Maria Cecília Focesi Pelicioni

Tel. 3066-7751 - Faculdade de Saúde Pública/USP

Depto. de Prática de Saúde Pública

Comitê de Ética da Faculdade de Saúde Pública - 3066-7779 


\section{TERMO DE CONSENTIMENTO LIVRE E ESCLARECIDO}

$\mathrm{Eu}$, integrante da comunidade educativa, na qualidade de pai/mãe ou responsável, aceito participar da pesquisa intitulada "Olhares e perspectivas sobre a educação ambiental, a democracia participativa e o empowerment de crianças e adolescentes em escolas da Rede Municipal de Enisno de São Paulo”. Estou ciente de que minha participação é livre, não obrigatória e de que poderá ser interrompida por minha decisão a qualquer momento, sem qualquer prejuízo. Sei que minha entrevista não será identificada, concordo que ela seja gravada e que a fita fique em poder da pesquisadora durante o período necessário para a conclusão da pesquisa. Se houver necessidade de novas informações procurarei a pesquisadora no endereço acima.

São Paulo, de de 200 


\section{ANEXO 2 - ROTEIRO PARA GRUPO FOCAL}

\section{DIRECIONADO A PROFESSORES INTEGRANTES DAS ESCOLAS PESQUISADAS}

1. Nos últimos cinco anos, quais foram os cursos oferecidos pela Rede dos quais vocês participaram?

2. Como vocês avaliariam esses cursos?

3. Vocês consideram importante realizar cursos de formação para professores na Rede? Por quê?

4. Os conteúdos desenvolvidos nesses cursos são aplicáveis em sala de aula? Por quê?

5. O que pode dificultar a aplicação dos conhecimentos adquiridos nos cursos em sala de aula?

6. Como vocês definiriam o papel do educador na escola atual?

7. O que vocês consideram como principal papel do aluno na Escola, ou seja, o que cabe aos alunos no processo educativo?

8. Que tipo de alunos a escola precisa formar?

9. Vocês consideram que a escola de hoje responde às principais questões da sociedade como: fortalecimento da democracia com a efetiva participação da população nas políticas públicas dos governos, combate à corrupção e a violência e o equilíbrio ambiental do Planeta? Por quê?

10. Esta Escola em particular tem tido essa preocupação e ela está contida no Projeto Político Pedagógico da Escola?

11. Que estratégias vocês têm utilizado para lidar com essas questões com seus alunos?

12. Vocês tiveram a oportunidade de participar das plenárias do OP na sua região nos anos de 2001 a 2004? Por que resolveram participar? Ou por que não participaram?

13. Por ocasião da elaboração do Plano Diretor da Cidade de São Paulo em 2002, foram realizadas reuniões em todas as subprefeituras da Cidade. Vocês tiveram a 
oportunidade de participar das plenárias na região onde moram e sabem o que foi decidido pela população? Por quê?

14. Vocês costumam participar do Sindicato dos Professores ou Associação dos Professores? Como?

15. Falem sobre o que vocês acham sobre o protagonismo infanto-juvenil na escola.

16. De que forma vocês puderam contribuir para a realização do OP-Criança e das Conferências Infanto-Juvenis do Meio Ambiente na Escola? Fale sobre o que acharam desse trabalho.

17. Vocês já pensaram em elaborar uma agenda 21 na Escola?

18. Como vocês definiriam um ambiente saudável?

19. Esta Escola poderia ser considerado um ambiente saudável? Por quê?

20. Na opinião de vocês, por que alguns projetos mesmo sendo considerados importantes não existem ou deixam de ter continuidade nos anos subseqüentes à sua criação? 


\section{ANEXO 3 - QUESTÕES DA ENTREVISTA COM PAIS DE ALUNOS E EX- ALUNOS DAS UNIDADES ESCOLARES PESQUISADAS}

Você está sendo convidado(a) a participar da pesquisa "OLHARES E PERSPECTIVAS SOBRE A EDUCAÇÃO AMBIENTAL, A DEMOCRACIA PARTICIPATIVA E O EMPOWERMENT DE CRIANÇAS E ADOLESCENTES EM ESCOLAS DA REDE MUNICIPAL DE ENSINO DE SÃO PAULO". Fica assegurado o sigilo de sua identidade pessoal bem como das informações fornecidas pelos participantes da mesma.

1. Em sua opinião, quais são as ações da escola que mais têm colaborado para transformar os alunos em cidadãos, ou seja, torná-los mais conscientes de seus deveres e direitos e atuantes no mundo em que vivem?

2. Você considera importante que seu filho aprenda como cuidar do meio ambiente e da saúde na escola?

3. O que vocês, pais, costumam ensinar sobre isso em suas casas para seus filhos?

4. Em sua opinião o que é um meio ambiente saudável para se viver?

5. Você acha que a escola de seu filho tem um meio ambiente saudável? Por quê?

6. Você poderia citar alguns projetos ou trabalhos que a escola de seu filho realiza com os alunos?

7. Você costuma participar da escola onde seu filho estuda? De que forma?

8. A escola de seu filho costuma convidar os pais para conhecerem propostas de trabalho e ajudarem a decidir sobre eles?

9. A escola costuma incentivar a iniciativa dos alunos para estes desenvolverem projetos e tomar decisões dentro da escola?

10. O que você sabe sobre o OP-Criança e as Conferências Infanto-Juvenis do Meio Ambiente?

11. Você sabe se seu filho participou desses projetos e o que ele achou deles?

12. O que você acha desse tipo de projeto na escola? Por quê?

13. Que tipo de projetos você acha que deveriam existir na escola para incentivar a participação dos alunos e o desenvolvimento da cidadania dos mesmos?

14. O que você acha que deveria ser feito para manter esses projetos nas escolas nos anos seguintes? 


\section{ANEXO 4 - QUESTÕES DA ENTREVISTA COM ALUNOS E EX-ALUNOS DAS UNIDADES ESCOLARES PESQUISADAS}

Você está sendo convidado(a) a participar da pesquisa "OLHARES E PERSPECTIVAS SOBRE A EDUCAÇÃO AMBIENTAL, A DEMOCRACIA PARTICIPATIVA E O EMPOWERMENT DE CRIANÇAS E ADOLESCENTES EM ESCOLAS DA REDE MUNICIPAL DE ENSINO DE SÃO PAULO”. Tenha certeza de que seu nome não será revelado nesta pesquisa.

1. Como você acha que deveriam ser tomadas as decisões na escola?

2. Em sua escola os alunos participaram dessas decisões? Como?

3. Você acha que os políticos que governam nosso País têm procurado ouvir a opinião das crianças, adolescentes e jovens sobre as políticas que afetam suas vidas, como por exemplo, na educação, na saúde e no lazer?

4. Você já teve a oportunidade de participar das Conferências Infanto-Juvenis do Meio Ambiente ou do OP-Criança na sua escola? Quando?

5. O que esses projetos trouxeram de bom para você dentro e fora da escola?

6. Existem outros projetos que incentivem a participação dos alunos em sua escola? Quais?

7. Por que você acha que alguns projetos interessantes deixam de existir de um ano para outro na escola?

8. O que você acha que um ambiente deve ter para ser considerado saudável?

9. Você acha que sua escola tem um ambiente saudável? Por quê?

10. O que é feito em sua escola para conservar ou melhorar o meio ambiente e a saúde de todos? 
ANEXO 5 - QUESTIONÁRIO COM AS EQUIPES TÉCNICAS (Direção, Assistentes de Direção, Auxiliares de Direção, Coordenadores Pedagógicos)

O presente questionário faz parte da pesquisa intitulada "OLHARES E PERSPECTIVAS SOBRE A EDUCAÇÃO AMBIENTAL, A DEMOCRACIA PARTICIPATIVA E O EMPOWERMENT DE CRIANÇAS E ADOLESCENTES EM ESCOLAS DA REDE MUNICIPAL DE ENSINO DE SẪO PAULO" e tem como objetivo obter alguns dados sobre a escola e conhecer a opinião dos educadores integrantes das equipes técnicas das Unidades Escolares pesquisadas, acerca das facilidades e dificuldades de implantação e incorporação de projetos voltados à participação de crianças e adolescentes, também chamada de protagonismo infanto-juvenil relacionada à educação ambiental no currículo permanente da escola.

\section{DADOS DA ESCOLA}

Turnos:

Número de salas:

Número de classes e alunos por ciclo:

\begin{tabular}{|l|l|l|}
\hline CICLO & CLASSES & $N^{\circ}$ DE ALUNOS \\
\hline I & & \\
\hline II & & \\
\hline
\end{tabular}

DADOS DO RENDIMENTO ESCOLAR NOS ÚLTIMOS CINCO ANOS

\begin{tabular}{|l|l|l|l|}
\hline $\begin{array}{l}\text { ANO DE } \\
\text { REFERENCIA }\end{array}$ & $\begin{array}{l}\text { ALUNOS } \\
\text { RETIDOS }\end{array}$ & $\begin{array}{l}\text { ALUNOS } \\
\text { PROMOVIDOS }\end{array}$ & $\begin{array}{l}\text { ALUNOS } \\
\text { EVADIDOS }\end{array}$ \\
\hline & & & \\
\hline & & & \\
\hline & & & \\
\hline & & & \\
\hline
\end{tabular}


1. Qual sua formação?

( ) Humanas ( ) Exatas ( ) Biológicas ( ) Pedagogia

2. Que cargo e/ou função ocupa na escola?

( ) Diretor ( )Assistente de Direção ( ) Coordenador Pedagógico

3. Há quantos anos trabalha na escola?

( ) menos de 5 anos ( ) de 5 a 10 anos ( ) mais de 10 anos

4. Na sua opinião, os principais problemas de sua escola são referentes à:

Gestão escolar ( ) não ( ) sim Quais?

Aprendizagem ( ) não ( ) sim Quais?

$-$

Outros:

5. A equipe técnica tem procurado solucionar esses problemas?

( ) não ( ) sim Como?

6. Nos últimos cinco anos, têm sido oferecidos cursos de formação para os integrantes das equipes técnicas das Rede Municipal de Ensino?

( ) não ( ) sim Quais?

7. Em caso afirmativo, você participou de algum desses cursos promovidos pela Secretaria Municipal de Educação?

( ) não ( ) sim De quais? 
8. Qual sua opinião em relação a esses cursos? Por favor, fale somente sobre cada um dos que você participou:

9. Você conhece algum projeto voltado para a participação de crianças e adolescentes, também conhecido como "protagonismo infanto-juvenil" na Rede Municipal de Ensino de São Paulo? ( ) não （ ）sim Quais?

10. Em caso afirmativo, nos últimos cinco anos qual (is) projeto(s) encaminhado(s) pela Secretaria Municipal de Educação para a sua escola ligados ao protagonismo infanto-juvenil, você considerou realmente importantes? Explique.

11. Qual(is) desse(s) projeto(s) se transformou (aram) em ações permanentes dentro da Unidade Escolar até os dias de hoje?

12. Na sua opinião o que facilitou ou impediu a implantação desses projetos na Unidade Escolar?

13. Sua escola participou do Orçamento Participativo Criança (OP-Criança) em 2003? ( ) não Por quê? （ ） sim

14. Sua escola participou do Orçamento Participativo Criança (OP-Criança) em 2004? ( ) não Por quê?

( ) $\operatorname{sim}$ 
15. Sua escola participou da I Conferência Infanto -Juvenil do Meio Ambiente em 2003? ( ) não Por quê? （ ) sim

16. Sua escola participou do Seminário de Formadores do Programa "Vamos Cuidar do Brasil" realizado em Novembro de 2004 para preparar a II Conferência Infanto-Juvenil do Meio Ambiente?
( ) não Por quê?
( ) $\operatorname{sim}$

17. Sua escola participou da II Conferência Infanto-Juvenil do Meio Ambiente em 2005? ( ) não Por quê? ( ) sim

18. Você já ouvir falar em Agenda 21 ? ( ) não （ ) sim Onde?

19. Em caso afirmativo, qual sua opinião sobre a Agenda 21?

20. Você já ouvir falar em Agenda 21 Escolar? ( ) não ( ) sim Onde?

$-$

21. Sua escola possui uma Agenda 21 Escolar? ( ) não Por quê? ( ) sim Por quê?

22. Em caso afirmativo, como ela foi construída?

23. Você considera saudável o meio ambiente de sua escola?
( ) não Por quê?
( ) Por quê? 
24. Que projeto(s) você sugeriria visando tornar o meio ambiente escolar mais saudável para toda a comunidade escolar (corpo docente, discente, equipe técnica, operacional e pais)?

25. Se você identificou algum projeto na questão anterior, explique o que facilitaria a sua implantação na Unidade Escolar. 